UNIVERSIDADE FEDERAL DE MINAS GERAIS

Programa de Pós-graduação Em Saneamento,

MEIO AMBIENTE E RECURSOS HídRICOS

\title{
ANÁLISE DA GESTÃO DE RECURSOS HÍDRICOS: UM ESTUDO DE CASO DO COMITÊ DA BACIA HIDROGRÁFICA DO RIO DAS VELHAS
}

Hildelano Delanusse Theodoro

Belo Horizonte

2017 


\section{ANÁLISE DA GESTÃO DE RECURSOS HÍDRICOS: UM ESTUDO DE CASO DO COMITÊ DA BACIA HIDROGRÁFICA DO RIO DAS VELHAS}

Hildelano Delanusse Theodoro 


\section{ANÁLISE DA GESTÃO DE RECURSOS HÍDRICOS: UM ESTUDO DE CASO DO COMITÊ DA BACIA HIDROGRÁFICA DO RIO DAS VELHAS}

Trabalho apresentado como requisito ao exame de Tese do Programa de Pós-graduação em Saneamento, Meio Ambiente e Recursos Hídricos da Universidade Federal de Minas Gerais.

Área de concentração: Recursos Hídricos

Linha de pesquisa: Políticas Públicas e Gestão em Saneamento, Meio Ambiente e Recursos Hídricos

Orientador: Nilo de Oliveira Nascimento

Coorientador: Léo Heller

Belo Horizonte

Escola de Engenharia da UFMG 
T388a Theodoro, Hildelano Delanusse.

Análise da gestão de recursos hídricos [manuscrito]: um estudo de caso do comitê da Bacia Hidrográfica do Rio das Velhas / Hildelano Delanusse. Theodoro. -2017 $267 \mathrm{f}$., enc; il.

Orientador: Nilo de Oliveira Nascimento. Coorientador: Léo Heller.

Tese (doutorado)-Universidade Federal de Minas Gerais, Escola de Engenharia.

Apêndices:f. 265-267.

Bibliografia:f. 246-264.

1. Engenharia sanitária - Teses. 2. Recursos hídricos - Desenvolvimento - Teses. 3. Recursos hídricos - Administração - Teses. 4. Políticas públicas Teses. 5. Desenvolvimento institucional - Teses. 6. Velhas, Rio das (MG)Teses. I. Nascimento, Nilo de Oliveira. II. Heller, Léo, 1955-. III. Universidade Federal de Minas Gerais. Escola de Engenharia. IV. Título. 


\section{HILDELANO DELANUSSE THEODORO}

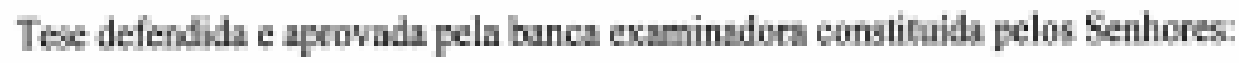

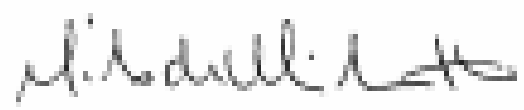

Prot, Nigo ge Olveika Nascmento - Orimbidot

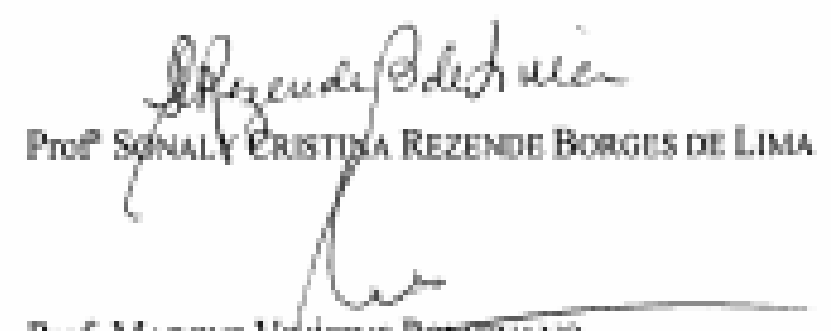

Prof: Maxus Vwigus Rerichand

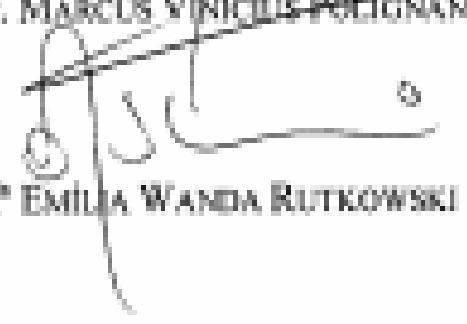

Apouda pelo Colejiado do PO SMARH

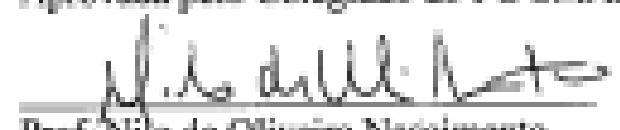

Prof. Nilo de Oliwara Mascitimente

Coordensdor

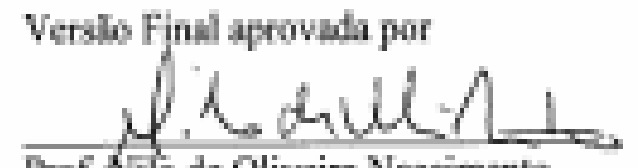

Prof. Nib da Oliveira Nasimento Orleniador

Beb Horiwaic, 19 de junho de 2017. 


\section{AGRADECIMENTOS}

Agradeço primeiramente pela realização deste trabalho a Deus, por ter me dado fé e força de vontade para persistir e poder me tornar uma pessoa e um profissional melhor, com capacidade para aceitar esse desafio e superar alguns de meus limites.

Também agradeço aos meus pais, Neuza Inácia da Silva Theodoro e Ildefonso Theodoro, pelo suporte que me deram e dão durante todos os momentos necessários de minha vida.

Ao meu irmão de coração, Ernani Souza, a minha eterna gratidão, assim como também para minha amiga Sirléia Rosa, que me ajudou a recuperar a minha fé, e para Cintia Carvalho, pessoa maravilhosa e que me ensinou a recomeçar de maneira diferente.

Aos Professores Nilo de Oliveira Nascimento e Léo Heller, a minha mais alta estima e admiração por seus incentivos constantes ao meu desenvolvimento e por acreditarem na proposta de pesquisa aqui apresentada.

Agradeço também à Coordenação de Aperfeiçoamento de Pessoal de Nível Superior (CAPES), por seu apoio institucional na realização do trabalho.

Aos professores do Programa de Pós-Graduação em Saneamento, Meio Ambiente e Recursos Hídricos eu agradeço por terem sempre mostrado acessibilidade para troca de informações e generosidade para ensinar.

Para os mais variados colegas que conheci durante o processo de doutoramento, segue também o meu agradecimento por iluminarem meus dias e me fazer sentir parte de uma equipe maior. Em especial aos amigos Erick Brizon, Rodrigo Lemos, Aline Nunes, Sarah Figueiredo, Talita, Daniel, Fernando e aos funcionários Júlio, Elaine e Yara - todos você conquistaram meu respeito e admiração

Finalmente, agradeço a todo o corpo administrativo da UFMG por terem me auxiliado em todas as etapas de construção de meu trabalho.

Programa de Pós-graduação em Saneamento, Meio Ambiente e Recursos Hídricos da UFMG 


\section{RESUMO}

O presente trabalho constitui uma análise sobre as principais políticas públicas de recursos hídricos relacionadas com a gestão institucional do Comitê da Bacia Hidrográfica do Rio das Velhas (CBHRV), um dos mais antigos e atuantes em Minas Gerais e no Brasil. Considerado como um modelo de gestão ainda em consolidação, o gerenciamento hídrico por organismos de bacia, com os comitês em especial, tem sido cada vez mais aplicado no campo institucional, porém ainda demanda maior conhecimento e entendimento conceitual e práticos sobre suas atuações legais e sociais. O objetivo é o de discutir e analisar tais políticas sob a ótica da gestão e de seus processos democráticos e participativos, com vistas à identificação das suas principais possibilidades e restrições que são existentes atualmente. Dessa forma, a estrutura organizacional implantada no referido comitê desde sua fundação em 1998 até o ano de 2015 é avaliada a partir dos critérios preliminarmente escolhidos de participação, transparência e práticas exercidas, dentre outros possíveis. Estes foram selecionados por possibilitarem ao trabalho identificar relações institucionais diversas e interdependentes de governança no comitê e, de forma geral, nas políticas públicas hídricas em Minas Gerais. Para tanto a pesquisa realiza discussões sobre aspectos legais, institucionais, econômicofinanceiros e de integração que são vinculadas ao comitê selecionado. Em termos metodológicos, é utilizada uma conjunção de pesquisa de campo, realizada por vários anos no próprio comitê e dentro das estruturas institucionais de recursos hídricos ("observação participante"); estudo crítico das principais deliberações relacionadas direta ou indiretamente com a gestão hídrica em geral e do CBHRV em particular (“análise documental"); interpretação das entrevistas individuais realizadas com as principais lideranças e personalidades vinculadas com o comitê e/ou tema proposto de pesquisa ("análise de conteúdo"). Este conjunto de investigação é aqui utilizado para a demonstração de como, a partir do estudo de caso escolhido de seus procedimentos administrativos e institucionais podem favorecer ou impedir contextos mais democráticos e participativos em um modelo de gerenciamento via comitê quadripartite (sociedade civil, poder público estadual, poder público municipal, setor privado).

Programa de Pós-graduação em Saneamento, Meio Ambiente e Recursos Hídricos da UFMG 


\begin{abstract}
The present research constitutes an analysis on the main public policies of water resources related to the institutional management of the River Basin Watershed Committee (CBHRV, in Portuguese), one of the oldest and most active in Minas Gerais and Brazil. Considered as a management model still under consolidation, water management by basin organizations, with committees in particular, has been increasingly applied in the institutional field, but still demands greater knowledge and conceptual and practical understanding of its legal and social actions. The objective is to discuss and analyze these policies from the point of view of management and its democratic and participatory processes, in order to identify the main possibilities and restrictions that currently exist. Thus, the organizational structure implemented in the said committee from its foundation in 1998 to the year 2015 is evaluated based on the preliminary selection criteria of participation, transparency and practices, among others possible. These were selected because they enable the work to identify diverse and interdependent institutional relations of governance in the committee and, in general, in the public water policies in Minas Gerais. For this, the research holds discussions on legal, institutional, economic-financial and integration dimensões that are linked to the selected committee. In methodological terms, a field research meeting is used, carried out for several years in the committee itself and within the institutional structures of water resources ("participant observation"); critical study of the main deliberations related directly or indirectly to water management in general and the CBHRV in particular ("documentary analysis"); interpretation of the individual interviews conducted with the main leaderships and personalities linked to the committee and / or the proposed research theme ("content analysis"). This set of research is used here to demonstrate how, from the chosen case study of its administrative and institutional procedures can favor or prevent more democratic and participatory contexts in a four-sectors management model (civil society, state public power, Municipal public power, private sector).
\end{abstract}

Programa de Pós-graduação em Saneamento, Meio Ambiente e Recursos Hídricos da UFMG 


\section{SUMÁRIO}

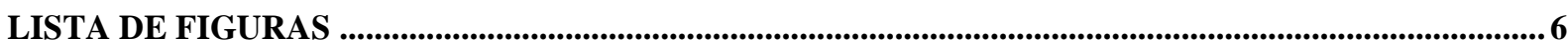

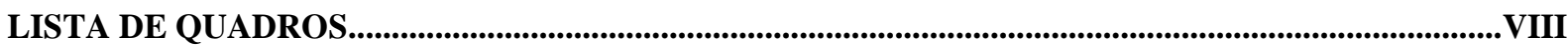

LISTA DE TABELAS ......................................................................................................................18

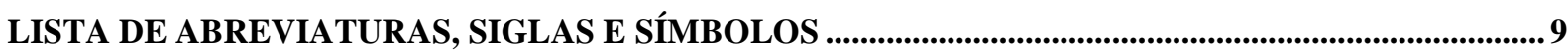

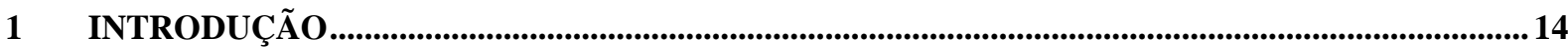

1.1 JUSTIFICATIVA DA PESQUISA ………………………............................................................................ 14

1.1.1 Relevância científica da pesquisa realizada ............................................................................ 14

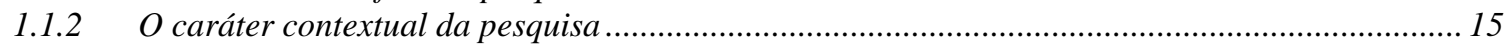

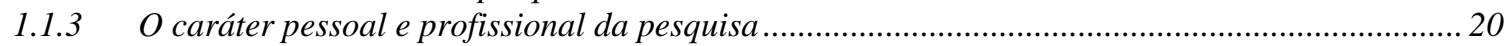

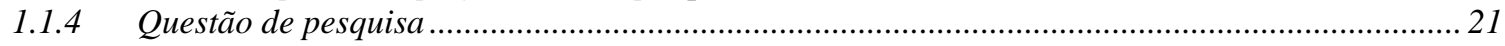

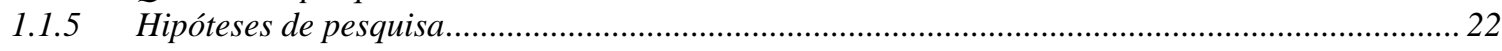

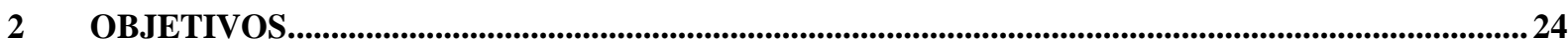

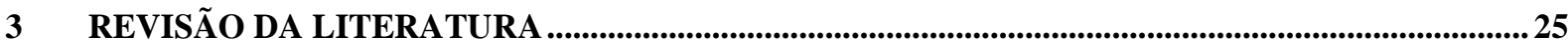

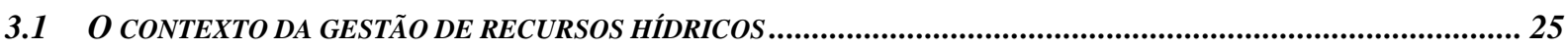

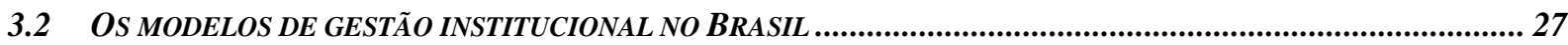

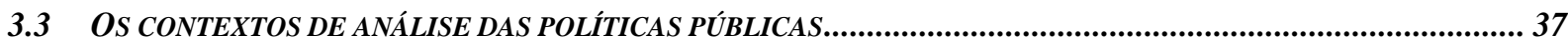

3.4 OS TIPOS DE POLÍTICAS PÚBLICAS........................................................................................................ 48

3.5 OS CICLOS DE POLÍTICAS PÚBLICAS ............................................... ERRO! INDICADOR NÃO DEFINIDO.

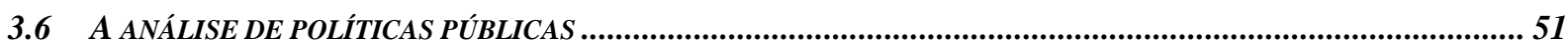

3.6.1 A importância da utilização de cenários de planejamento................. Erro! Indicador nãa definido.

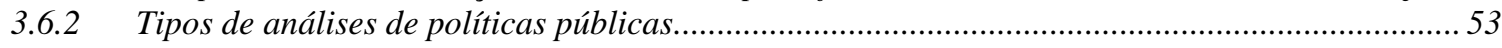

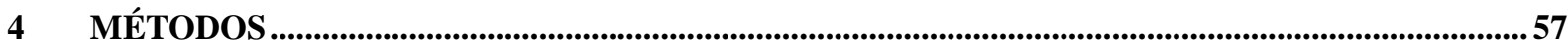

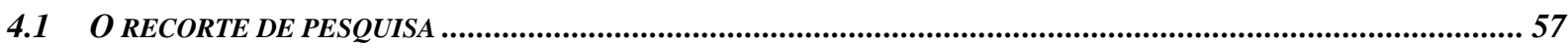

4.1.1 Fontes de pesquisa ........................................................................................................ 57

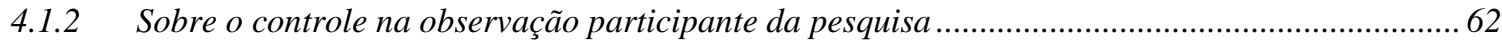

4.1.3 Retorno aos entrevistados................................................................. Erro! Indicador näo definido.

4.2 A “TRIANGULAÇÃO DE MÉTODOS” COMO METODOLOGIA DE ANÁLISE ……………….................................. 64

4.4 CARACTERIZAÇÃO E JUSTIFICATIVA DA ESCOLHA DOS ENTREVISTADOS.................................................... 66

4.5 A “ANÁLISE DE CONTEÚDO” COMO MARCO REFERENCIAL PARA ANÁLISE DE ENTREVISTAS......................... 68

4.6 OS “ESTUDOS DE CASOS” COMO MARCO REFERENCIAL PARA ANÁLISES COMPARATIVAS.............................. 73

5 ESTUDO DE CASO: O COMITÊ DA BACIA HIDROGRÁFICA DO RIO DAS VELHAS .............76

5.1 CARACTERIZAÇÃ O GERAL DA BACIA ..................................................................................................... 76

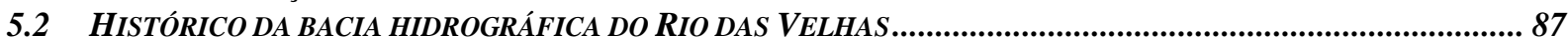

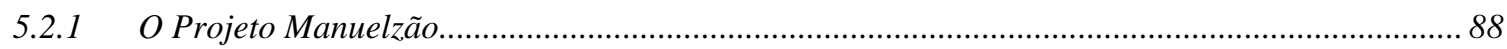

5.2.2 Organização do Projeto Manuelzão........................................................................................... 93

5.2.3 A "Meta 2010" e a "Meta 2014" como catalisadoras de ações ....................................................... 96

5.3 O COMITÊ DA BACIA HIDROGRÁFICA DO RIO DAS VELHAS (CBHRV) ...................................................... 100

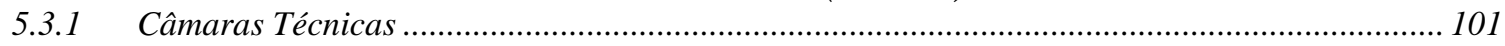

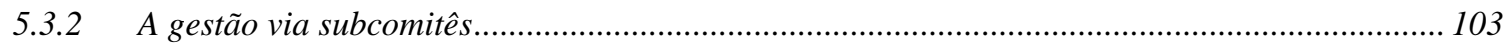

5.4 SOBRE OS CONFLITOS IDENTIFICADOS NO CBHRV ………....................................................................... 106

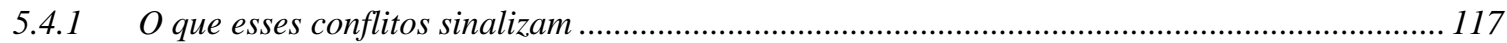

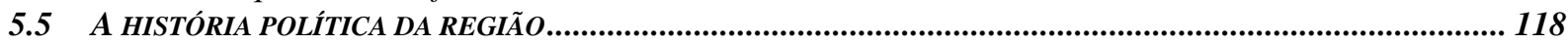

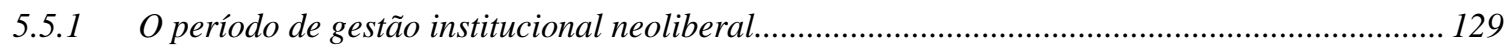

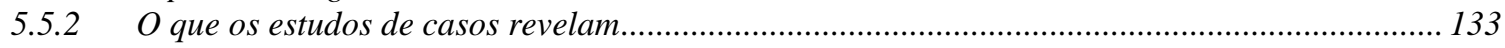

5.5.3 Características de comitês que avançaram na gestão das políticas públicas de recursos hídricos

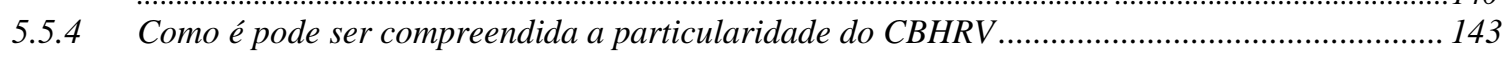

Programa de Pós-graduação em Saneamento, Meio Ambiente e Recursos Hídricos da UFMG 


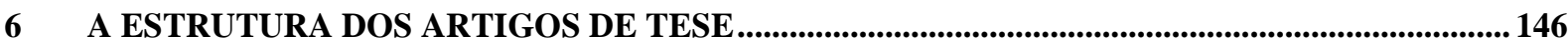

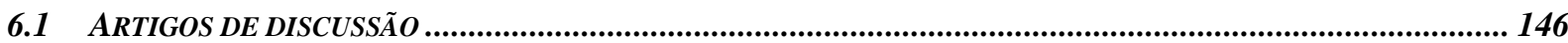

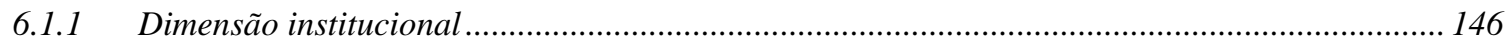

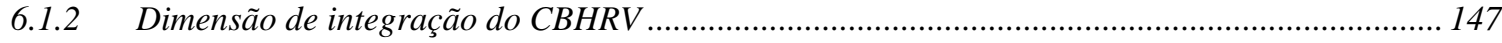

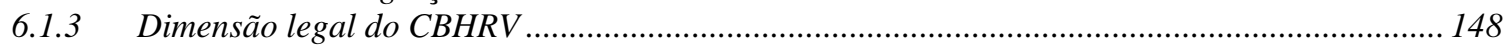

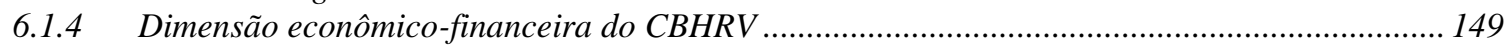

6.1.5 Relação de artigos produzidos ....................................................... Erro! Indicador não definido.

7 A INSTITUCIONALIZAÇÃO DA GESTÃO DE RECURSOS HÍDRICOS NA BACIA HIDROGRÁFICA DO RIO DAS VELHAS, MINAS GERAIS, BRASIL, SOB A ÓTICA

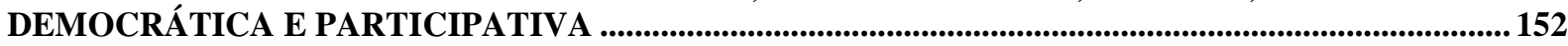

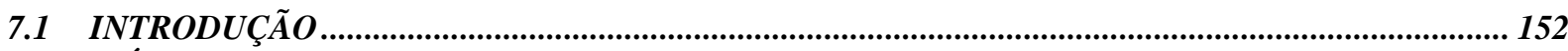

7.2 MÉTODOS

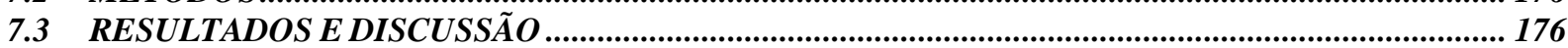

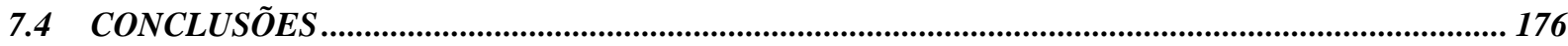

8 OS DESAFIOS INSTITUCIONAIS DE GESTÃO HÍDRICA EM UM MODELO DE PARTICIPAÇÃO QUADRIPARTITE: O CASO DO COMITÊ DA BACIA HIDROGRÁFICA DO RIO

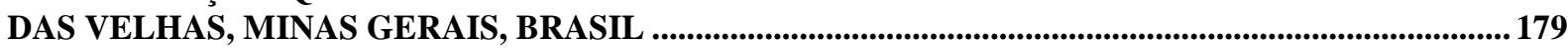

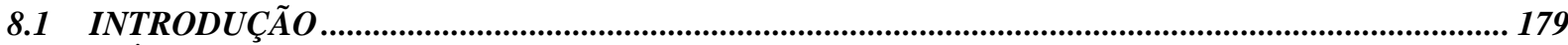

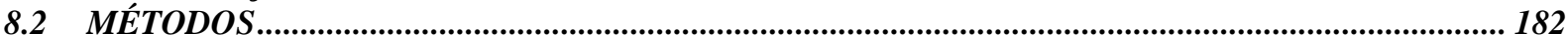

8.3 RESULTADOS E DISCUSS ÂO

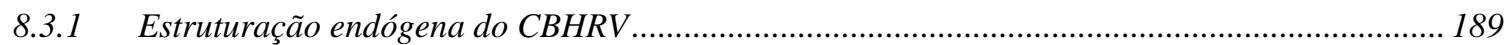

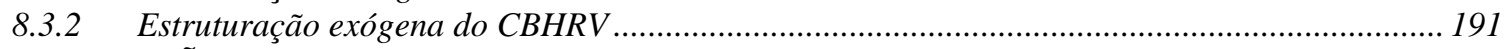

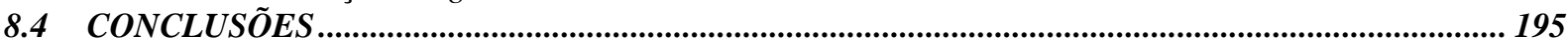

9 DESCENTRALIZAÇÃO INSTITUCIONAL E GESTÃO DE RECURSOS HÍDRICOS SOB O ENFOQUE LEGAL: O CASO DO COMITÊ DA BACIA HIDROGRÁFICA DO RIO DAS VELHAS, MG, BRASIL ................................................................................................................................................ 197

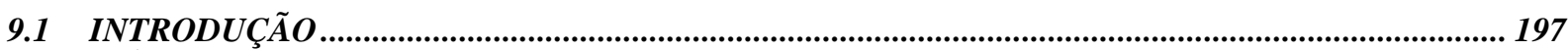

9.2 MÉTODOS

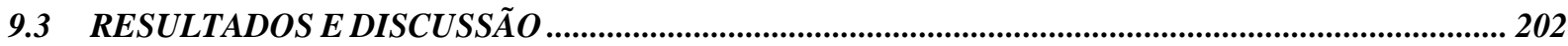

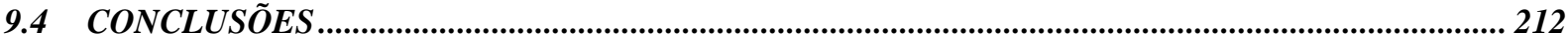

10 RECURSOS ECONÔMICOS-FINANCEIROS PARA A CONSTRUÇÃO DA GOVERNANÇA DOS RECURSOS HÍDRICOS. INSUFICIÊNCIAS, ASSIMETRIAS E OPACIDADES NA BACIA HIDROGRÁFICA DO RIO DAS VELHAS, MINAS GERAIS, BRASIL ....................................................214

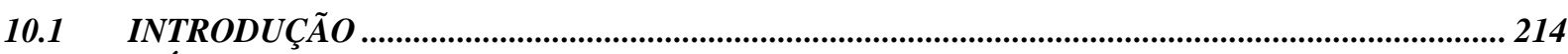

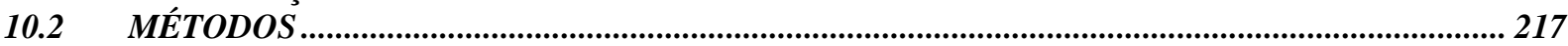

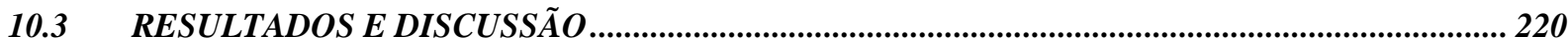

10.3.1 A institucionalização da gestão de recursos econômico-financeiros no CBHRV ..................... 220

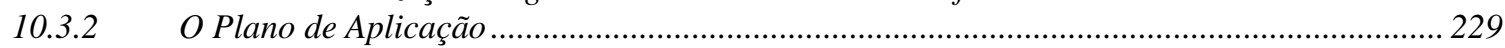

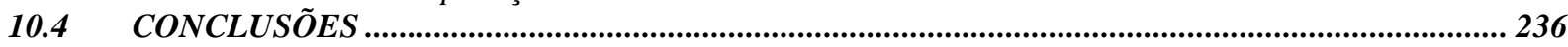

11 CONSIDERAÇÕES FINAIS ............................................................................................................238

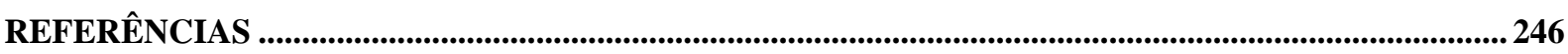

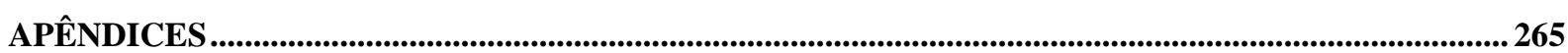

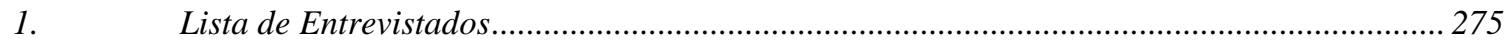

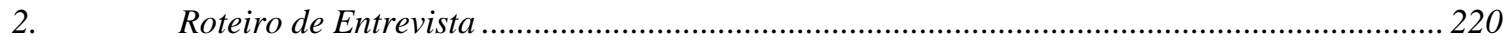

Programa de Pós-graduação em Saneamento, Meio Ambiente e Recursos Hídricos da UFMG 


\section{LISTA DE FIGURAS}

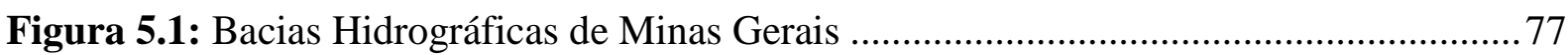

Figura 5.2: Unidades de Planejamento e Gestão de Recursos Hídricos (UPGRHs) ............... 79

Figura 5.3: Divisão administrativa da bacia hidrográfica do Rio das Velhas (1998-2014) .... 82

Figura 5.4: Unidades Territoriais Estratégicas da bacia hidrográfica do Rio das Velhas (2015)

Figura 5.5: Segmentação administrativa da bacia hidrográfica do Rio das Velhas (2015) ....85

Figura 5.6: Primeira equipe do "Projeto Manuelzão", com a participação do próprio, no centro da fotografia; o idealizador, sr. Apolo Henringer Lisboa, se encontra agachado ao mesmo.

Figura 5.7: Organização do Projeto Manuelzão

Figura 5.8: Subcomitês da bacia hidrográfica do Rio das Velhas 105

Figura 5.9: Bacias hidrográficas da Região Metropolitana de Belo Horizonte 122

Figura 7.1: Estrutura mínima proposta para o Sistema Nacional de Recursos Hídricos 155

Figura 7.2: Avanço da institucionalização das políticas públicas estaduais de recursos hídricos (a) e da implementação de comitês de bacia hidrográfica no Brasil (b)

Figura 7.3: Unidades de Planejamento e Gestão de Recursos Hídricos 170

Figura 7.4: Subcomitês da bacia hidrográfica do Rio das Velhas

Figura 9.1: Síntese histórica das legislações estaduais de recursos hídricos no Brasil

Figura 10.1: Finalidades outorgadas para uso de recursos hídricos em 2013, em MG 216

Figura 10.2: Localizações da bacia hidrográfica do Rio das Velhas: a) no país e na bacia hidrográfica do Rio São Francisco; b) na bacia hidrográfica do Rio São Francisco e em Minas Gerais 218

Figura 10.3: Evolução da arrecadação com a cobrança pelo uso de recursos hídricos de domínio da União 225

Figura 10.4: Procedimento para encaminhamento de demandas de projetos no CBHRV ....231 


\section{LISTA DE QUADROS}

Quadro 3.1: Principais características dos modelos de gestão institucional brasileiros ... Erro! Indicador não definido.

Quadro 3.2: Caracterização das políticas públicas segundo o tipo de impacto sobre a implementação Erro! Indicador não definido.

Quadro 4.1: Técnicas de coleta de dados selecionadas 70

Quadro 5.1: Relação entre as UTEs e as regiões da bacia hidrográfica do Rio das Velhas a partir do Plano Diretor de Recursos Hídricos, revisado e publicado em 2015.

Quadro 5.2: Histórico das principais atividades vinculadas ao Rio da Velhas e Projeto Manuelzão

Quadro 5.3: Comparação entre as vinculações municipais e o CBHRV, RMBH e CMBH.126

Quadro 6.1: Relação de artigos publicados segundo os objetivos da pesquisaErro! Indicador não definido.

Quadro 6.2: Relação de artigos produzidos a partir da pesquisa, indiretamente Erro! Indicador não definido.

Quadro 7.1: Participação, Transparência e Práticas no CBHRV 175

Quadro 8.1: Restrições e possibilidades à integração endógena e exógena do CBHRV

Quadro 9.1: Avanços na gestão hídrica após a Constituição Federal de 1988 .204

Quadro 9.2: Instrumentos de gestão de recursos hídricos nas unidades federativas brasileiras 206

Quadro 9.3: Atribuições determinadas aos Comitês de Bacia Hidrográfica (CBHs) 210 


\section{LISTA DE TABELAS}

Tabela 5.1: Características gerais da bacia hidrográfica do Rio das Velhas .......................... 81

Tabela 8.1: Análise comparativa entre alguns CBHs ..................................................... 187

Tabela 10.1: Total arrecadado até 2014 pela cobrança pelo uso de recursos hídricos nas bacias implantadas em Minas Gerais.............................................................................. 227

Tabela 10.2: Demonstrativo de valores cobrados e arrecadados na bacia hidrográfica do Rio

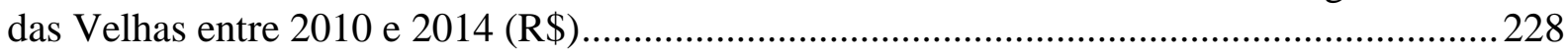

Tabela 10.3: Totais de arrecadação e repasses no CBHRV ...............................................233 


\section{LISTA DE ABREVIATURAS, SIGLAS E SÍMBOLOS}

ADAO

ABAS

ABES

ABHA

ACOMCHAMA

ADAO

$\mathrm{ADMBH}$

AGB

AGBPV

AGEVAP

ANA

ANSP

ASSUVE

BEMGE

BID

BOVESPA
Associação de Desenvolvimento de Artes e Ofícios

Associação Brasileira de Águas Subterrâneas

Associação Brasileira de Engenharia Sanitária e Ambiental

Associação Multissetorial de Usuários de Recursos Hídricos da Bacia Hidrográfica do Rio Araguari

Associação Comunitária dos Chacareiros do Maravilha

Associação de Desenvolvimento de Artes e Ofícios

Agência de Desenvolvimento Metropolitano de Belo Horizonte

Agência de Bacia

Associação Executiva de Apoio à Gestão de Bacias Hidrográficas Peixe Vivo

Associação Pró-Gestão das Águas da Bacia Hidrográfica do Rio Paraíba do Sul

Agência Nacional de Águas

Associação dos Proprietários das Chácaras da Rua Nossa Senhora da Piedade

Associação de Usuários Pró-Gestão das Águas da Bacia Hidrográfica do Rio das Velhas

Banco do Estado de Minas Gerais

Banco Interamericano de Desenvolvimento

Bolsa de Valores de São Paulo 
CAUC Cadastro Único de Convênios

CBH Comitê de Bacia Hidrográfica

CBHRV Comitê da Bacia Hidrográfica do Rio das Velhas

CBHSF Comitê da Bacia Hidrográfica do Rio São Francisco

CEEIBH Comitê Especial de Estudos Integrados de Bacias Hidrográficas

CEIVAP Comitê de Integração da Bacia Hidrográfica do Rio Paraíba do Sul

CEMIG Companhia Energética de Minas Gerais

CERH Conselho Estadual de Recursos Hídricos

CIBACAP Consórcio Intermunicipal da Bacia do Rio Capivara

CMBH Colar Metropolitano de Belo Horizonte

CNARH Cadastro Nacional de Recursos Hídricos

CNM Confederação Nacional de Municípios

COPASA Companhia de Saneamento de Minas Gerais

COPATI Consórcio para Proteção Ambiental do Rio Tibagi

CREA Conselho Regional de Engenharia e Agrimensura

CT Câmara Técnica

DAC Declaração de Área de Conflito

DAE Documento de Arrecadação Estadual

DE Decreto Estadual

DN Deliberação Normativa

Programa de Pós-graduação em Saneamento, Meio Ambiente e Recursos Hídricos da UFMG 
EMATER

Empresa de Assistência Técnica e Extensão Rural do Estado de Minas Gerais

ETE

Estação de Tratamento de Esgoto

FAEMG

Federação da Agricultura e Pecuária do Estado de Minas Gerais

FETAEMG

Federação dos Trabalhadores na Agricultura do Estado de Minas Gerais

FHIDRO

Fundo de Recuperação, Proteção e Desenvolvimento Sustentável das Bacias Hidrográficas do Estado de Minas Gerais

FIEMG

Federação das Indústrias do Estado de Minas Gerais

FUNDEP

Fundação de Desenvolvimento da Pesquisa

FURB

Universidade Regional de Blumenau

GRANBEL

Associação dos Municípios da Região Metropolitana de Belo Horizonte

HIDROTEC Programa de pesquisa e desenvolvimento para a geração e transferência de tecnologia de suporte para o planejamento e gestão hídrica

IBGE

Instituto Brasileiro de Geografia e Estatística

IBRAM

Instituto Brasileiro de Mineração

IES

Instituição de Ensino Superior

IGAM

Instituto Mineiro de Gestão das Águas

IWRM

Integrated Water Resources Management

MMA

Ministério do Meio Ambiente

NuVelhas

Núcleo Transdisciplinar e Transinstitucional pela Revitalização da bacia do Rio das Velhas

Programa de Pós-graduação em Saneamento, Meio Ambiente e Recursos Hídricos da UFMG 
PBH

Prefeitura de Belo Horizonte

PDRH Plano Diretor de Recursos Hídricos

PERH

Plano Estadual de Recursos Hídricos

PLANSAB

Plano Nacional de Saneamento Básico

PLS

Plano de Lei do Senado

PMDB

Partido do Movimento Democrático Brasileiro

PMSB

Plano Municipal de Saneamento Básico

PNRH

Política Nacional de Recursos Hídricos

PNMA

Política Nacional de Meio Ambiente

PNRS

Política Nacional de Resíduos Sólidos

PPA

Plano Plurianual de Aplicação

PSDB

Partido da Social Democracia Brasileira

PSB

Partido Socialista Brasileiro

PT

Partido dos Trabalhadores

$\mathrm{RM}$

Região Metropolitana

$\mathrm{RMBH}$

Região Metropolitana de Belo Horizonte

RMVA

Região Metropolitana do Vale do Aço

RURALMINAS Fundação Rural Mineira

SAAE

Serviço Autônomo de Água e Esgoto

SEE

Secretaria Estadual de Educação

Programa de Pós-graduação em Saneamento, Meio Ambiente e Recursos Hídricos da UFMG 
SEGRH

SEMAD

SEPLAG

SEPLAN

SEGRH-MG

SINGREH

SISEMA

SMARH

SUPRAM

TVA

UFMG

UFV

UnB

UPGRH

UTE
Sistema Estadual de Gerenciamento de Recursos Hídricos

Secretaria de Estado do Meio Ambiente e Desenvolvimento Sustentável

Secretaria de Estado de Planejamento e Gestão

Secretaria Estadual de Planejamento

Sistema Estadual de Gerenciamento de Recursos Hídricos do estado de Minas Gerais

Sistema Nacional de Gerenciamento de Recursos Hídricos

Sistema Estadual de Meio Ambiente

Programa de Pós-Graduação em Saneamento, Meio Ambiente e Recursos Hídricos

Superintendência Regional de Meio Ambiente

Tennessee Valley Authority

Universidade Federal de Minas Gerais

Universidade Federal de Viçosa

Universidade de Brasília

Unidade de Planejamento e Gestão de Recursos Hídricos

Unidade Territorial Estratégica 


\section{INTRODUÇÃO}

A emergência das questões hídricas nas últimas décadas e, principalmente, a partir do início dos anos 2000 reflete uma série de preocupações em termos de suas fragilidades e potencialidades que demandam ser melhor analisadas no campo acadêmico. Os recursos hídricos são cada vez mais considerados não apenas como bens naturais e insumos para as atividades produtivas, da mesma forma como indicadores dos níveis de qualidade socioambiental presente nas regiões em que estão localizados.

Na mesma direção, a ação estatal tem sido repensada para dar conta dos novos desafios institucionais e organizacionais presentes no cenário municipal, regional, nacional e internacional da gestão hídrica. E as ações para que mudanças efetivas sejam realizadas no campo hídrico estão baseadas nas políticas públicas disponíveis para tanto. Consequementemente, a análise das principais ações institucionais e políticas ocorridas na região de estudo, a bacia hidrográfica do Rio das Velhas, tem relação com o momento atual das políticas públicas serem entendidas como suporte para processos crescente de maior participação social, transparência nas ações governamentais e a implantação de planos diretores de recursos hídricos, saneamento, gestão municipal urbana, dentre outros.

\subsection{Justificativa da pesquisa}

\subsubsection{Relevância científica da pesquisa realizada}

A pesquisa se justifica como um trabalho de área de fronteira e de interface entre as engenharias e as ciências sociais e ciências sociais aplicadas, principalmente, no que pode ampliar a capacidade explicativa da pesquisa. Cada vez mais há uma demanda em estudar e gerar discussões sobre áreas que, aparentemente, não são afins, mesmo que sobre o mesmo objeto de pesquisa. Pois as resistências em trabalhar campos de conhecimento distintos é uma realidade que é poucas vezes considerada no sentido de sua superação, de pensar reformas institucionais e funcionais (MORIN, 2003; BOBBIO, 2007).

Por outro lado, as possibilidades de apontar novos caminhos de melhoramentos de gestão e participação social, assim como na ciência como um todo se daria justamente ao haver pesquisas de mais de uma interface, tal como colocado em GIROLETTI (2005, p. 120):

Programa de Pós-graduação em Saneamento, Meio Ambiente e Recursos Hídricos da UFMG 
"Sabe-se, hoje, que as grandes descobertas científicas ocorrem em domínios intermediários ou em zonas incertas e fronteiriças, o que estimula a interdisciplinaridade".

Já em termos metodológicos, a utilização de análises comparativas que tem, por proposta, uma perspectiva qualitativa dos processos de gestão de recursos hídricos que visam aumento da participação e democracia social também deve ser colocada, uma vez que

A pesquisa qualitativa é, em si mesma, um campo de investigação. Ela atravessa disciplinas, campos e temas. Em torno do tema pesquisa qualitativa, encontra-se uma família interligada e complexa de termos, conceitos e suposições. (...) Existem literaturas independentes e detalhadas sobre o grande número de métodos e de abordagens classificados como pesquisa qualitativa, tais como o estudo de caso, a política e a ética, a investigação participativa, a entrevista, a observação participante, os métodos visuais e a análise interpretativa. (DENZIN e LINCOLN, 2006, p. 16).

Fato é que a abordagem mais tradicionalista e corrente de análise de políticas públicas possuem forte base tecnocêntrica, estrutural somente, e não se demonstram mais serem capazes de tratar com exatidão temática a cada vez mais complexa gestão hídrica (HELLER e REZENDE, 2012). Tal como salienta JURY e JR (2005, p. 15.717):

Um local de hospedagem de questões institucionais, políticas públicas e gerenciamento precisam estar endereçadas pelas ciências sociais fundamentais e aplicadas, o que tem sido largamente negligenciado em anos recentes. (...) Novas e inovadoras contribuições irão ser necessárias de todas as ciências sociais. Essas contribuições serão críticas para a compreensão do comportamento do uso hídrico e para institucional, de políticas públicas, e de gerenciamento de questões e para a criação de instituições efetivas para o gerenciamento hídrico em tempos de intensa escassez.

O enquadramento da análise da pesquisa foi o de verificar os principais avanços e entraves ao desenvolvimento da participação social dentro dos processos de gestão hídrica no Rio das Velhas, a destacar qual a posição adotada pelo comitê dentro do contexto institucional desde sua fundação.

\subsubsection{O caráter contextual da pesquisa}

Uma das questões principais em termos da necessidade de tal tipo de pesquisa tal como apresentada aqui é vinculado ao fato de que o PDRH da bacia hidrográfica do Rio das Velhas terminou recentemente seu processo de atualização (CBHRV, 2015) sob gerenciamento da

Programa de Pós-graduação em Saneamento, Meio Ambiente e Recursos Hídricos da UFMG 
Associação Executiva de Apoio à Gestão de Bacias Hidrográficas Peixe Vivo, AGBPV ${ }^{1}$, que é a agência de água da referida bacia e que visa a implantação de várias políticas públicas que ainda não foram efetivadas ou discutidas para a bacia. Dentre elas estão desde um biomonitoramento mais amplo, a passar por questões do desenvolvimento do turismo e das regiões social e economicamente desfavorecidas, como também o reenquadramento de alguns trechos de corpos d'água. Essas políticas precisam também de suporte tanto metodológico como avaliativo de suas funções, capacidade de resposta e efetividade de realizações (o que indica mudança das realidades das populações e locações envolvidas nos processos de tomadas de decisões).

Oficialmente, o comitê aprovou o seu novo PDRH da bacia hidrográfica do Rio das Velhas, após atualização, via a sua Deliberação Normativa 02/15, promulgada em 25 de março de 2015, considerando as decisões do Plenário da 83ª Reunião Ordinária realizada na mesma data anteriormente citada.

Uma vez que o processo de atualização está balizado em preceitos jurídicos (BRASIL, 1997; POMPEU, 2010), administrativos (SILVA e PRUSKI, 2000) e institucionais (CAMARGOS, 2005; THEODORO, 2002; COSTA, 2008), a realização de um estudo sobre o nível de gestão participativa existente nas políticas públicas de recursos hídricos a partir do CBHRV pode ajudar na compreensão dos elementos institucionais e organizacionais em geral que demandam intervenções diretas ou diferenciadas (ARRETCHE, 1998; FIGUEIREDO e FIGUEIREDO, 1986).

Como todo processo de planejamento institucional e político vinculado com o planejamento de recursos hídricos, existe a pressuposição de revisões periódicas dos mesmos, de forma a melhor os processos de gestão envolvidos. No caso do CBHRV (2015, p. 128), fica estabelecida a necessidade de revisões a cada oitos anos sobre a situação da referida bacia para dar conta de seus desafios estruturais:

Para garantir a continuidade do processo de planejamento dos recursos hídricos da bacia do rio das Velhas, faz-se necessário promover revisões a cada oito anos do Plano Diretor de Recursos Hídricos, com revisão das previsões orçamentárias a cada

\footnotetext{
${ }^{1}$ Que é uma pessoa jurídica de direito privado, formada por organizações da sociedade civil e também por usuários de recursos hídricos, o que a constitui como uma associação civil (IGAM, 2014(a)). Vale ressaltar que possui caráter de delegação administrativa de temporalidade indeterminada, com vinculação legal estadual e federal, além das oriundas dos comitês sob sua responsabilidade.
}

Programa de Pós-graduação em Saneamento, Meio Ambiente e Recursos Hídricos da UFMG 
quatro anos. Para a realização das revisões e atualizações do PDRH Rio das Velhas ficam estabelecidas as seguintes diretrizes:

- Elaboração dos Termos de Referência para o processo de revisão do Plano de Recursos Hídricos;

- Preparação de processo licitatório para contratação dos serviços técnicos de consultoria para elaboração das revisões do plano;

- Desenvolvimento dos estudos técnicos com acompanhamento do CBH Rio das Velhas e AGB Peixe Vivo e do órgão envolvido: IGAM. (...)

Mais ainda, o país atravessou recentemente um forte período de seca e estiagem que começou no ano de 2012 e atingiu seu ápice no ano de 2014 - especificamente as regiões Sudeste, Centro-Oeste e Nordeste foram as que tiveram secas mais longas e persistentes. O que fez com que o sistema de gestão de recursos hídricos brasileiro fosse colocado em dúvida, dada a sequência de eventos severos que aconteceram (ANA, 2015(a); IGAM, 2015(b)). É uma situação que criou uma crise hídrica e institucional com poucos precedentes em relação aos recursos hídricos nacionais, pois atingiu várias regiões:

Desde 2012, observa-se uma gradativa e intensa redução nos índices pluviométricos em algumas regiões do País. Esse fenômeno climático tem prejudicado de forma significativa a oferta de água para o abastecimento público, especialmente no semiárido brasileiro e nas regiões metropolitanas mais populosas e com maior demanda hídrica (São Paulo e Rio de Janeiro). Outros setores que dependem do armazenamento da água para se viabilizarem operacionalmente, como o de irrigação e o de energia hidrelétrica (principal matriz energética do País) também estão sendo afetados pela falta de chuvas e pelo menor volume de água armazenado nos reservatórios. (ANA, 2015(b), p. 5).

Além disso, há pesquisas que têm indicado (ATLAS BRASIL, 2013; JÚNIOR, 2013) que há uma baixa garantia hídrica no território brasileiro em vários estados da federação, o que tem exigido um retorno aos princípios do planejamento, execução, análise e avaliação dos processos de gestão hídrica, ou melhor, de gestão institucional. Até porquê, de acordo com ANA (2015(a)), o número de decretos de Situação de Emergência (ou Estado de Calamidade Pública) relacionados à seca cresceram a partir do ano de 2012, mantiveram uma estabilidade em 2013. A região nordeste teve maior concentração de casos, porém eventos extremos foram identificados em 2014 na região sudeste, principalmente no estado de São Paulo.

Minas Gerais não foi diferente desse cenário, sendo que a bacia hidrográfica do Rio das Velhas teve períodos de emergência de intervenção institucional para controle dos recursos hídricos (CBHRV, 2015, IGAM, 2014) - ou como afirmou um representante do segmento da sociedade civil entrevistado: "A crise da água se deve mesmo é à forma como o homem trata 
a natureza. Ou como não trata dela, não é? A crise hídrica é também uma demonstração da crise maior da ordem pública, na minha opinião.".

Essa situação se agravou no final de 2013 quando o Instituto Mineiro de Gestão das Águas $(\mathrm{IGAM})^{2}$ foi chamado a intervir nos processos de conflitos (em parceria também com a AGBPV) que ocorreram na região do chamado "Alto Rio das Velhas" (que abarca a Região Metropolitana de Belo Horizonte, de forma geral). Além disso, o comitê teve de usar sua rede de contatos institucionais para divulgar a realidade dos crescentes impactos aos mananciais CBHRV (2015(b)):

\begin{abstract}
No mês de outubro de 2014 a vazão do Rio das Velhas chegou a $9 \mathrm{~m}^{3} / \mathrm{s}$, por vezes menos que isso, até $8 \mathrm{~m}^{3} / \mathrm{s}$ na região de Bela Fama, abaixo da média histórica e dos quais $6 \mathrm{~m}^{3} / \mathrm{s}$ estavam sendo retirados para abastecimento da Região Metropolitana de Belo Horizonte. A situação preocupante fez com que o Comitê chamasse a imprensa para comunicar o fato e alertar a população quanto aos cuidados necessários e a possibilidade da falta de água potável na Grande BH. Para o CBH Rio das Velhas é fundamental que os órgãos executores e o governo assumam problemas como este e elaborem ações voltadas à gestão dos recursos hídricos.
\end{abstract}

Essa realidade de falta contingencial ou recorrente de recursos hídricos, assim como no acesso a esses por uma parte considerável da população faz com que haja um problema de ordem socioeconômico a ser resolvido, uma vez que, como visto nas discussões presentes em Castro, Heller, Morais (2015, p. 228)

A Organização Mundial de Saúde (OMS) destaca que todas as pessoas, em quaisquer estágios de desenvolvimento e condições socioeconômicas, têm direito a um suprimento adequado de água. Por isso, o fenômeno se apresenta como desafio às políticas que visam ao desenvolvimento local sustentável (OMS, 2001).

Isso verificado, o presente trabalho pode contribuir no sentido de se antecipar políticas públicas que possam gerenciar melhor esses acontecimentos de escassez hídrica. Primeiramente para que tal contribuição possa ocorrer, é preciso distinguir que seca é um fenômeno natural sazonal, diferente de escassez, que é um fenômeno social e recorrente, fruto da (falta de) aplicação de instrumentos adequados de gestão (ANA, 2009; ANA (2015(b)); CASTRO, HELLER e MORAIS (2015). Em termos globais, por exemplo, é pertinente destacar que a questão das mudanças climáticas têm sido cada vez mais considerada como

2 O Instituto Mineiro de Gestão das Águas (IGAM) foi criado em julho de 1997, sendo vinculado à Secretaria de Estado de Meio Ambiente e Desenvolvimento Sustentável (SEMAD), mas foi regulamentado apenas 17 anos depois, em 2014.

Programa de Pós-graduação em Saneamento, Meio Ambiente e Recursos Hídricos da UFMG 
fator de influência para a emergência de uma tendência para a ocorrência mais frequente de períodos de seca mais severos (GIDDENS, 2010; ANA, 2015(a)).

Há também a hipótese de que o desmatamento da floresta amazônica esteja repercutindo sobre o regime de chuvas no Brasil central e sudeste, modificando-os cada vez mais. Mesmo que tais questões não estejam no escopo direto da pesquisa, vale destacá-los como fatores de influências crescentes nas considerações de políticas públicas de cunho socioambiental como, por exemplo, na construção de cenários de intervenção governamental ou na realização de obras de infraestrutura.

Inclusive, a partir de Jury e Jr. (2005), a grande questão atual e futura sobre recursos hídricos reside justamente sobre o debate em relação à sua escassez e provável(eis) crise(s). Isso porque haveria, segundo esses autores, uma tendência de realocação dos recursos hídricos dos setores agrícolas e ambientais para o setor urbano. Assim, os futuros planejamentos hídricos deveriam focar mais em eventos extremos e nas variabilidades dos mesmos - uma possibilidade à esta preocupação é a inserção do planejamento por cenários de gestão (PEREIRA; HELLER, 2015; CBHRV, 2015(a)).

Isso porque entre as duas temáticas (seca e escassez) existe a questão da prestação dos serviços hídricos, que é a gestão em si, o que envolve todo o rol de procedimentos técnicos e jurídicos que tratam direta ou indiretamente sobre as mesmas. No caso da região sudeste do Brasil, onde está localizada a bacia hidrográfica do Rio das Velhas, algumas regiões que apresentaram períodos de seca se converteram em regiões de escassez hídrica. Saíram de uma característica intermitente para permanente enquanto eventos climáticos e sociais.

Para o próprio CBHRV, e também para algumas das lideranças entrevistadas para essa pesquisa, o cenário da bacia já poderia ser considerado de escassez mais do que de seca, visto que a quantidade disponível de recursos hídricos tem sido cada vez menor. E isso se aconteceria não apenas pelas condições climáticas adversas, mas também pela ação antrópica, via o grande volume de água que tem sido retirado dos rios, tributários ou não do Rio das Velhas, por usuários particulares de todos os portes (ABES, 2014; CBHRV, 2015(c); CBH PARACATU (2016); IGAM (2013). Esses, normalmente, não seguem ou não aguardam os 
procedimentos para outorga de direito de uso dos recursos hídricos ${ }^{3}$, causando sérios prejuízos ao meio ambiente da região.

\subsubsection{O caráter pessoal e profissional da pesquisa}

O trabalho aqui apresentado é consequência de uma história pessoal e profissional feito por uma escolha direcionada ao aprofundamento sobre as formas possível de desenvolvimento e de aperfeiçoamento sobre políticas públicas de recursos hídricos. Tais caminhos foram percorridos a partir do ano de 1999, após o término dos estudos realizados no bacharelado em Ciências Sociais na Universidade Federal de Minas Gerais (UFMG). Este período foi seguido pelo Mestrado em Extensão Rural na Universidade Federal de Viçosa (UFV), onde foi realizada a dissertação sobre "Instituições e Recursos Hídricos em Minas Gerais", que se tornou livro em 2013. E em 2012 ocorreu o início dos estudos ao nível de doutorado no Programa de Pós-Graduação em Saneamento, Meio Ambiente e Recursos Hídricos (SMARH) da Universidade Federal de Minas Gerais (UFMG).

A proposta inicial de trabalho partiu do interesse em descobrir as principais restrições e potencialidades para o avanço da gestão de recursos hídricos em Minas Gerais. Isso se deu pelo envolvimento do pesquisador, até o final de 2012, como membro do estudo de caso, que é o Comitê da Bacia Hidrográfica do Rio das Velhas (CBHRV). Com o início do presente estudo, houve o afastamento dessa atividade diretamente vinculada ao comitê. Em 2014 houve o lançamento, como organizador e autor, do livro "Desenho Institucional, Democracia e Participação: conexões teóricas e possibilidades de análise” e em 2015, também como organizador e autor, do livro "Governança e Recursos Hídricos: experiências nacionais e internacionais de gestão".

Nesse sentido, a continuidade do processo de formação como pesquisador e como pessoa passa certamente pela conclusão do presente trabalho, que visa contribuir ao aprofundamento

3 A outorga é um dos instrumentos previstas na Lei Federal $n^{\circ}$ 9.433/97 e que tem como objetivo assegurar de todas as formas legais possíveis, o controle tanto qualitativo quanto quantitativo dos recursos hídricos, assim como o acesso aos mesmos. São passíveis de outorgas os seguintes usos: I - derivação ou captação de parcela da água existente em um corpo de água para consumo final, inclusive abastecimento público, ou insumo de processo produtivo; II - extração de água de aquíf́ero subterrâneo para consumo final ou insumo de processo produtivo; III - lançamento em corpo de água de esgotos e demais resíduos líquidos ou gasosos, tratados ou não, com o fim de sua diluição, transporte ou disposição final; IV - aproveitamento dos potenciais hidrelétricos; V - outros usos que alterem o regime, a quantidade ou a qualidade da água existente em um corpo de água.

Programa de Pós-graduação em Saneamento, Meio Ambiente e Recursos Hídricos da UFMG 
da compreensão de como melhorar as políticas públicas hídricas brasileiras minimamente. Mais do que um desejo pessoal é uma demanda atual que a própria pesquisa pretende demonstrar, que é assumida aqui no sentido de que a ciência ambiental é, primeiramente, um processo social (NORGAARD, 1992). Igualmente, a compreensão dos eventos sociais e institucionais que contribuem para resistências ou potencialidades na gestão é de meu interesse pessoal e profissional.

\subsubsection{Questão de pesquisa}

A pesquisa aqui colocada se associa com a emergência das políticas públicas serem direcionadas ao campo da gestão participativa, mesmo que esse posicionamento se encontre apenas no campo do discurso e não do curso das ações efetivamente implantadas. Verificar assim o distanciamento entre teoria e práxis, alicerçada em recursos documentais, entrevistas e por observação participante em vários oportunidades e temporalidades foi a opção de pesquisa realizada. Até porquê, "Para as ciências sociais, uma teoria desligada da prática não chega sequer a ser uma teoria. E é nesse sentido que muitos diriam ser a prática o critério da verdade teórica." (DEMO, 1985, p 45).

Nessa direção, a pesquisa se propõe, em termos de originalidade e direcionamento, tentar responder à questão sobre como se realizou o desenvolvimento institucional das políticas públicas de recursos hídricos na bacia hidrográfica do Rio da Velhas. Visa se identificar quais as suas principais fronteiras, restrições e potencialidades em termos de políticas públicas e pelo estudo de caso do comitê da referida área. A investigação proposta pretende dar resposta(s) à questão fundamental sobre "quais são os principais fatores de restrição $e$ potencialidade das ações do CBHRV a partir de uma perspectiva de gestão participativa $e$ democrática?".

Tal questionamento visa amparar intelectual e metodologicamente possíveis explicações sobre quais os aperfeiçoamentos institucionais e organizacionais necessários ao CBHRV, na direção de se tentar identificar também, a questão sobre qual o papel de atuação institucional é esperado de um comitê de bacia hidrográfica brasileiro, e do CBHRV em particular, na busca da identificação de suas imperfeições e seus desenvolvimentos, uma vez que 
A metodologia analítica surge a partir da insatisfação. (...) Ao perguntar por que as coisas são feitas de uma certa maneira, ela desenvolve uma descrição logicamente defensável do que antes talvez houvesse sido apenas uma coletânea de práticas costumeiras. Podemos então aperfeiçoar a prática cotidiana, concebendo atividades de pesquisa segundo o que deveriam ser, a fim de que desempenhem o papel adequado no método, conforme a análise dele feita. (BECKER, 1997, p. 25).

A partir daí é possível examinar as possibilidades de incremento da participação social como um todo (sociedade civil, usuários, poder público municipal e poder público estadual), de modo a ser conseguir identificar se ao se descentralizar os processos de gestão de recursos hídricos na bacia hidrográfica do Rio das Velhas é verificado que o gerenciamento hídrico se tornou mais democrático e participativo.

Consequentemente, um fator que provavelmente se torna primordial para que as práticas de atuação do CBHRV e da própria agência de água, a Associação Executiva de Apoio à Gestão de Bacias Hidrográficas Peixe Vivo, AGBPV, sejam melhor compreendidas, assim como da gestão de recursos hídricos em Minas Gerais como um todo se relacionada consequentemente com a questão sobre de quais formas tem sido realizados os investimentos econômicofinanceiros na bacia hidrográfica do Rio das Velhas e quais seus principais procedimentos, aplicações e afins.

Tais questões de pesquisa se interferem na medida de suas demandas comparativas entre o modelo institucional-legal e as práticas organizacionais cotidianas em seus processos de tomadas de decisão, para a consolidação de uma gestão mais democrática, participativa e integrada, e com maior capacidade de resposta aos problemas socioambientais e institucionais existentes. Acredita-se que este conjunto de perguntas se justifica por suas pertinências em termos de que há uma necessidade por maior conhecimento sobre os modelos de comitês de bacia existentes como também por pesquisas que possam identificar possíveis melhorias institucionais.

\subsubsection{Hipóteses de pesquisa}

Após a apresentação das questões tanto de pesquisa quanto daquelas que fundamentam as hipóteses a serem trabalhadas, opta-se pela análise de quatro tipos de hipóteses para a tese. Essa divisão se mostrou necessária para dar capacidade de explicação à proposta colocada de se analisar a gestão dos recursos hídricos através de um estudo de caso. Dessa forma, definiram-se algumas dimensões de explicação da realidade da gestão e suas possíveis causas,

Programa de Pós-graduação em Saneamento, Meio Ambiente e Recursos Hídricos da UFMG 
como indica Santos e Filho (2011, p. $\left.150^{4}\right)$ e também Becker $\left(1997\right.$, p. $45^{5}$ ), para orientar a realização das técnicas de coleta e análise de dados:

Hipótese da Dimensão Institucional: As políticas públicas brasileiras de recursos hídricos e seus arranjos institucionais em Minas Gerais têm orientado as ações do CBHRV para uma consolidação gradativa de processos institucionais pela descentralização participativa via práticas de gestão por sub-bacias, subcomitês e ações políticas de promoção da transparência institucional.

Hipótese da Dimensão Integradora: O CBHRV ainda não possui uma prática de gestão integrada completamente consolidada entre seus membros e área de influência, fato de que a divisão quadripartite possibilitou uma maior integração do que o modelo de gestão por comitê tradicional, principalmente em relação com os outros organismos de bacia e órgãos competentes. Isso significa a busca pela compreensão das interações entre os membros do comitê, internamente, e as interações do comitê, externamente, com os órgãos responsáveis pela gestão hídrica da bacia referida.

Hipótese da Dimensão Legal: Há uma distância conceitual e operacional entre as determinações legais da gestão (leis, deliberações normativas, etc) e as práticas e resultados alcançados ao nível do CBHRV.

Hipótese da Dimensão Econômico-Financeira: Uma vez que a gestão econômicofinanceira dos recursos hídricos da bacia hidrográfica do Rio das Velhas, se dá através da sua agência executiva (a AGBPV) e a partir das deliberações do CBHRV (em bases administrativas e legais), forma-se um tipo de gestão das políticas públicas pode reproduzir assimetrias de poder dentro dos processos de tomada de decisão da gestão dos recursos hídricos. A base de análise é feita a partir das vinculações de captações de recursos previstos pelo uso múltiplo dos recursos hídricos e os gastos efetuados para o período de análise proposto.

\footnotetext{
4 “A hipótese tem como função orientar o pesquisador na direção da causa possível, sugerindo-se experiências próprias para a comprovação ou não do fato.” (SANTOS e FILHO, 2011)

5 "Uma boa hipótese, mais uma vez, é aquela que parece organizar muitos dados, aquela à qual podemos vincular outras sub-hipóteses que fazem uso de outras parcelas dos nossos dados, deste modo aglutinando as várias hipóteses que alimentamos em um todo mais amplo. Uma boa hipótese é aquela que não entra em choque com quaisquer dos fatos que temos à nossa disposição.".
}

Programa de Pós-graduação em Saneamento, Meio Ambiente e Recursos Hídricos da UFMG 


\section{OBJETIVOS}

Diante do exposto sobre a questão de pesquisa e suas hipóteses, o objetivo geral da tese é o de analisar as políticas públicas de recursos hídricos e suas aplicações, pelo estudo de caso do Comitê da Bacia Hidrográfica do Rio das Velhas e identificar possíveis restrições e potencialidades ao seu funcionamento e desenvolvimento. Para conseguir desenvolver adequadamente o objetivo geral selecionado, são estabelecidos os seguintes objetivos específicos:

- Analisar histórica e institucionalmente, sob a ótica das políticas públicas brasileiras, a estrutura organizacional implantada no CBHRV desde sua fundação (1998) até o término do quarto mandato de gestão do comitê (2012);

- Identificar as principais práticas institucionais de gestão participativa de recursos hídricos realizadas pelo CBHRV;

- Debater sobre os tipos de modelos institucionais de gestão de recursos hídricos implantados no país e quais as consequências geradas por tais escolhas para a gestão ambiental e hídrica como um todo.

Discutir o desempenho do modelo de gestão via comitê de bacia hidrográfica no Rio das

Velhas, a partir da perspectiva de suas dimensões institucional, econômica-financeira, integradora e legal.

Programa de Pós-graduação em Saneamento, Meio Ambiente e Recursos Hídricos da UFMG 


\section{REVISÃO DA LITERATURA}

\subsection{O contexto da gestão de recursos hídricos ${ }^{6}$}

Para a compreensão de como acontece a política de implantação da gestão de recursos hídricos em uma estrutura como a da brasileira, via organismos de bacia (comitês, agências, consórcios, órgãos reguladores, conselhos estadual e federal, etc) e com proposta de participação social e democrática em todos os níveis de decisão, uma análise dos modelos institucionais que foram implantados no país é colocada. Isso porque essa ação de discussão sobre a tipologia de gerenciamento institucional pode revelar as escolhas de áreas de atuação, temporalidade dos planos, programas e projetos em geral, quais os principais atores sociais envolvidos e, principalmente, como foi consolidado o sistema de gestão hídrica. Primeiramente, cabe ressaltar que um dos fundamentos da Política Nacional de Recursos Hídricos (PNRH) prevista na Lei Federal n 9.433/97, Art. $1^{\circ}$, Inciso V é de que “(...) a bacia hidrográfica é a unidade territorial para implementação da Política Nacional de Recursos Hídricos e atuação do Sistema Nacional de Gerenciamento de Recursos Hídricos; (...)”.

O que significa que há um local de operação da institucionalização hídrica no país e no território mineiro (JÚNIOR, 2016), o que demanda um corpo administrativo estruturado como “organismos de bacia", que são considerados aqui tal como em CEIVAP (2016):

\footnotetext{
"Organismo de bacia" é a denominação genérica para diversos tipos de entidades ou órgãos criados para atuar no espaço geográfico de uma bacia hidrográfica. Engloba, portanto, os comitês, agências, associações civis, organizações não governamentais, associações e consórcios intermunicipais e outras entidades semelhantes.
}

Importa ressaltar também que, junto com estas entidades/órgãos considerados como organismos de bacia, também existem organizações que podem ser consideradas como componentes tanto do processo de gestão como um todo, como também inseridas nas determinações oriundas da PNRH e que integrem o Sistema Nacional de Gerenciamento de Recursos Hídricos. Salienta-se que são organizações que podem atual em bacias hidrográficas na medida em que são organismos que atuam no território, mas que não são organismos de bacia em si. Eles são: 1) Conselho Nacional de Recursos Hídricos; 2) Agência Nacional de Águas; 3) Conselhos de Recursos Hídricos dos Estados e do Distrito Federal; 4) Agências de

\footnotetext{
6 A análise de modelos institucionais de recursos hídricos, com foco em Minas Gerais, se tornou artigo enviado, aprovado e publicado na Revista Sustentabilidade em Debate (UnB), Vol. 5, No 1, p. 117-135, jan/abr, 2004, classificação Qualis B3, Interdisciplinar.
}

Programa de Pós-graduação em Saneamento, Meio Ambiente e Recursos Hídricos da UFMG 
Água; 5) órgãos públicos federais, estaduais, municipais e do Distrito Federal que tenham relação direta ou indireta com o gerenciamento hídrico (secretarias, ministérios, agências reguladoras, etc).

Isso demanda dar significado a essas entidades em suas relações com as políticas públicas de recursos hídricos, inclusive em razão das possíveis leituras que são feitas pelos autores sobre suas capacidades de intervenção. De forma geral, demanda um tipo de esforço de pesquisa para discutir como, quando e por quê foram institucionalizadas.

O surgimento do interesse sobre o tema (políticas públicas) remete à segunda metade do Século XX, principalmente a partir de uma reforma da noção de Estado moderno. Ele (Estado) passa da função puramente provedora de ações ao público e passa a ser cada vez mais um gestor de suas políticas junto aos outros atores (FREY, 2000; HENKES, 2014).

E especificamente em relação aos recursos hídricos, a questão tem se destacado cada vez mais como um bem dotado não só de valor intrínseco como também econômico e inserida em um contexto de crescente degradação e exploração ambiental, desastres naturais e também demanda populacional (GIDDENS, 2010; DENHEZ, 2013), a água (e sua gestão) é uma temática indicadora também de formas de se fazer políticas públicas ao redor do mundo (PAQUEROT, 2005).

Mais ainda, os recursos hídricos se tornaram na atualidade um assunto em ascensão em campos do conhecimento e o aprofundamento de suas discussões é cada vez maior (GREEN, 2007, BECK et al., 1997).

Basicamente, o cenário da gestão de recursos hídricos no Brasil é reflexo das decisões tomadas pelos órgãos públicos a partir de duas perspectivas:

1) A da "forma" como que os recursos hídricos foram considerados em termos econômicos e jurídicos a partir do "Código das Águas" de 1934 (Decreto n 24.643, de 10 de julho de 1934) com forte caráter centralizador e burocrático, focado no desenvolvimento de setores de infraestrutura e produção nacional ${ }^{7}$, com o paralelismo

7 Tanto que, de acordo com o caput do Decreto, é destacada a importância de se garantir a energia hidráulica e, também, que "Resolve decretar o seguinte Código das Águas, cuja execução compete ao Ministério da Agricultura e que vai assinado pelos ministros de Estado.”.

Programa de Pós-graduação em Saneamento, Meio Ambiente e Recursos Hídricos da UFMG 
de ações de controle e fiscalização dos recursos naturais direcionadas basicamente ao setor produtivo;

2) A da "reforma" do aparelho jurídico-institucional relativo aos recursos hídricos como um todo, a partir da Política Nacional de Recursos Hídricos de 1997, que traz em seu cerne a concepção da gestão integrada e participativa, com maior presença de setores sociais e também da participação do setor privado ${ }^{8}$.

Entre esses dois momentos há um desenvolvimento histórico-institucional que remete aos modelos de gestão adotados no país, cada qual com características bem particulares, sendo os dois primeiros relacionados ao modelo de gestão tradicional e o último relacionados ao modelo participativo, mais democrático (a partir de THEODORO, 2002; MACHADO, 2003(b); CAMPOS; FRACALANZA, 2010; JOHNSSON; LOPES, 2003, THEODORO; MARQUES, 2014).

\subsection{Os modelos de gestão institucional no Brasil}

O primeiro passo para a compreensão dos processos de tomada de decisão que estão vinculadas com as políticas públicas institucionais e hídricas deve ser dado na exposição sobre os principais modelos adotados. Esses modelos não são significativos apenas no sentido dos sistemas operacionais de gestão que eles colocam em prática a cada dia, mas principalmente por permitirem que as análises das políticas tenham uma base da história institucional e política estabelecida aos recursos hídricos.

E se partimos do pressuposto de que há uma série de restrições ao desenvolvimento institucional no país, assim como em sua questão social há muito tempo precária ${ }^{9}$, a identificação das linhas gerais de atuação do sistema de gestão pode ajudar a mapear as possibilidades que também surgem em cada arranjo organizacional, como discutido em Mello (2006) e jurídico, como colocado em Machado (2003; 2003(a)); Júnior (2006) e, principalmente em Henkes (2014).

Por um lado, as discussões sobre os modelos institucionais que são implantados vêm de perspectivas tradicionais (ROGERS e HALL, 2003; BANCO MUNDIAL, 2003; GWP, 1999;

\footnotetext{
8 A ressaltar que já havia uma mudança conceitual sobre a temática ambiental a ocorrer a partir dos anos 1980s, sendo uma prova desse novo direcionamenteo a Política Nacional de Meio Ambiente, concretizada na Lei Federal $n^{\circ} 6.938$, de 1981.

Em PNUD(2015) é possível a identificação de que entre os 188 pesquisados sobre o Índice de Desenvolvimento Humano (IDH) pesquisados, o Brasil estava na posição de número 75.
}

Programa de Pós-graduação em Saneamento, Meio Ambiente e Recursos Hídricos da UFMG 
UNDP, 2003; SIMPSON e RINGSKOG, 1997). Nessas, há uma tentativa de explicação da gestão via organogramas e tomadas de decisão que são ainda hierarquizadas e de pouca articulação entre os atores existentes. Os fatores econômico-financeiros são mais destacados, em um planejamento burocratizado.

Por outro lado, há uma crescente releitura dos limites de atuação desses modelos a partir de uma ótica de gestão descentralizada e participativa (SWYNGEDOUW, 2005; LUCHINI, 2000), inclusive para países em desenvolvimento (TRAWICK, 2005; TORTAJADA e CASTELAN, 2003). Nessa perspectiva, a participação social, com a inclusão de grupos minoritários e que têm sido historicamente excluídos dos processos de gestão, é fundamental para que novas práticas de gestão aconteçam.

Como destaca MCDONNEL (2008), existem questões sobre quais serviços serão realizados em cada modelo, quem pagará, qual escala de investimentos envolvida, quem gerenciará o sistema e também o banco de dados etc. O que significa que colocar em prática as teorias sobre gerenciamento de recursos hídricos é desafiador e demanda instrumentos institucionais minimamente integrados entre si. É uma discussão próxima àquela feita em TOTTI e AZEVEDO (2013, p. 43) de que "Este é, portanto, o grande desafio da gestão dos recursos de uso comum: coordenar os diversos interesses de uso a fim de manter os estoques e, ao mesmo tempo, permitir o uso por parte de todos".

Essencialmente, pode ser feito um recorte histórico-institucional-legal sobre os tipos de modelos de gestão hídrica brasileiros a partir de três posições organizacionais diferentes (e já discutidas em THEODORO, 2002; ESMAN, UPHOFF, 1989; VELLOSO, 2000; SILVA, PRUSKI, 2000; BOURLON, BERTHON, 1998): 1) Modelo de gestão burocrática; 2) Modelo de gestão econômica; 3) Modelo de gestão participativa. Dentre suas características e fundamentos, esses modelos se pautam por arranjos institucionais distintos entre si e que refletem os momentos históricos (em nível nacional e internacional) pelo qual o país atravessava:

\section{Modelo de gestão burocrático:}

O conceito de burocracia, tão discutido e consolidado a partir das discussões clássicas de Weber (1999), como uma proposta de formalismo estruturado e controlado pela ordem estatal, encontrou várias formas de se estabelecer para o gerenciamento público nacional, 
principalmente em uma recente república federativa como a brasileira. A possibilidade de um aumento da capacidade de controle dos gastos e investimentos estruturais foi fator de destaque para uma sociedade em processo de formação de sua infraestrutura e serviços (THEODORO, 2004).

Para a área ambiental hídrica, por exemplo, a gestão burocrática apareceu conjuntamente à implantação do Código das Águas de 1934, onde há, como já indicado, uma forte delimitação de atuação do poder de Estado (POMPEU, 2010) no controle dos bens naturais, agora considerados como "recursos" aos sistemas de produção, destacadamente de energia e indústrias em geral. Historicamente é um momento de afirmação do modelo de produção capitalista no Estado brasileiro, via o $1^{\circ}$ governo de Getúlio Vargas (1930-1945).

Nesse momento e modelo há uma forte prerrogativa de atuação estatal onde praticamente inexiste a noção consultiva e deliberativa da sociedade civil, sendo a decisão descendente (“top-down ${ }^{10, "), ~ c o m ~ o s ~ u s u a ́ r i o s ~ t e n d o ~ m a i s ~ a t u a c ̧ a ̃ o ~ d e v i d o ~ a o s ~ i n t e r e s s e s ~ d o ~ s i s t e m a ~ d e ~}$ infraestrutura e desenvolvimento no país.

Sendo a burocracia considerada como um instrumento de normatização e orientação de uma dada estrutura organizacional, ela pode permitir espaços para aperfeiçoamento de decisões de políticas públicas (RIBEIRO, 2005), o que inerentemente deve acontecer via interação. E praticamente porque a burocracia pressupõe a especialização de corpo técnico e operacional (TOTTI, AZEVEDO, 2013; WEBER, 1999; THEODORO, MARQUES, 2014) para propiciar maiores resultados à máquina estatal, o que ainda não era o caso, uma vez que a organização desse aparato institucional era incipiente. Além desse fato estrutural, há que considerar que os conceitos de eficiência funcional estritamente burocráticos aqui colocados resistem:

a) aos aspectos sociológicos envolvidos em processos de tomada de decisão, tais como busca por conciliação, disputas de poder e conflitos internos (SOARES, 2008; CAMPOS, FRACALANZA, 2010; MOREIRA et al., 2014; ABERS, KECK, 2004; BECKER, 1997; CARNEIRO, ASSIS, 2012);

\footnotetext{
10 "O Enfoque Top-Down - também conhecido como "Implementação Programada" - tem como ponto de partida a asserção de que a implementação se inicia com uma decisão do governo central, a qual define a relação entre os objetivos da política pública - determinados pelas lideranças políticas - e os meios a serem mobilizados pelos diferentes níveis da burocracia a fim de produzir os resultados pretendidos." - Rua e Romanini (2013, p. 92).
}

Programa de Pós-graduação em Saneamento, Meio Ambiente e Recursos Hídricos da UFMG 
b) aos aspectos administrativos de análise e avaliação das políticas públicas como instrumento para o melhoramento das mesmas (SANDERSON, 2002; RIBEIRO, 2006);

c) aos aspectos jurídicos de controle da gestão, que delimita as formas de atuação da estrutura pública institucional (MACHADO, 2003(a); MALUF, 2013).

Essas afirmativas se relacionam com o tema em foco na medida em que demonstram que o modelo tradicional burocrático se, por um lado, propiciou uma estruturação do setor hídrico nacional, por outro não demonstrou abertura para que um processo participativo existisse.

Esse modelo com alto controle estatal se manteve por muitas décadas e ainda é sentida sua influência na definição das práticas de gestão (IADB, 2016). Principalmente em regiões onde o capital social envolvido ainda não está desenvolvido historicamente (PUTNAM, 1998; GIDDENS, 2010), assim como de paralelismo de agendas de políticas públicas ambientais. Isso significa que ocorrem decisões administrativas e determinações jurídicas (por exemplo: deliberações normativas) semelhantes em instituições político-administrativas distintas, causando inclusive a sobreposição de ações.

\section{Modelo de gestão econômica}

Com a expansão dos setores industriais brasileiros e produtivos de forma geral, o meio ambiente continuou a ser considerado como um insumo aos processos produtivos de forma geral. Mesmo que inserido em um discurso progressista e desenvolvimentista bem caracterizado a partir da década de 1950 e onde o poder público federal foi o principal incentivador de investimentos, com a fundação de órgãos de gestão pública. Interessante notar que foi justamente no período que alguns autores identificam como o de emergência do desenvolvimento dos estudos sobre políticas públicas (SOUZA, 2006; LOWI, 1964; RUA e ROMANINI, 2006; FREY, 2000) e de releitura do papel estatal dentro do cenário econômico e social dos países.

O Estado passa de forma gradual a ser não somente o executor de políticas de infraestrutura, mas também um gestor. Para que isso fosse realizado, ele utilizou como principal mecanismo a interação via mercado com base setorial, e tendo suporte nos investidores do setor privado (DULCI, 1999; THEODORO, 2002; CAMPOS, FRACALANZA, 2010).

Programa de Pós-graduação em Saneamento, Meio Ambiente e Recursos Hídricos da UFMG 
Foi um momento de altos investimentos na infraestrutura brasileira, em um período político desenvolvimentista advindo do $2^{\circ}$ governo de Getúlio Vargas (1951-1954) e depois principalmente incrementado no governo de Juscelino Kubitschek (1956-1961). Esse ambiente propiciou o avanço na utilização dos bens naturais como suporte para a macroeconomia em andamento na época (FEAM, 1998); consequentemente, há um aumento no nível da degradação socioambiental no país. Em termos de planejamento, por trabalhar uma escala intersetorial, ele ocorreu com mais amplitude do que o modelo burocrático e tecnicista, o que favoreceu um aumento mínimo nas formas de participação da sociedade civil e usuários de água.

Ao mesmo tempo, porém, isso ocasionou tanto a emergência de instituições setoriais que a sobreposição de interesses e decisões foi incrementada, o que é próximo das explicações vistas em ABERS e KECK (2013, p. 17):

Como em muitos lugars, as leis e instituições brasileiras falharam historicamente em considerar a necessidade de compatibilizar tantos usos entre si e com a proteção ambiental. Diferentes políticas públicas setoriais (saneamento, indústria, agricultura, energia), cada uma com suas próprias regras e programas, geralmente com projetos competindo pelo uso da água.

\section{Modelo de gestão participativa}

Já a partir do início da década de 1970 e com mais intensidade na década de 1980, a leitura sobre os bens naturais, agora admitidos como recursos envolvidos nos preceitos econômicos, passou a ser modificada. Houve um reconhecimento dos limites da atuação apenas burocrática e setorial que era desenvolvida no pais, que foi também reflexo das decisões tomadas em instâncias internacionais de acordos, blocos econômicos (NEDER (2002); NEDER (2001), PRESTE (2000)) e agências multilaterais (KAUFMANN e KRAAY, 2003). Foi um momento de revisão de algumas posturas de relação entre o Estado e o meio ambiente, em um processo não linear e feito a partir de vários conflitos entre os grupos de interesses envolvidos e em certas partes do mundo (HOORNBEEDK, 2004).

Essa nova realidade, inclusive, já havia sido identificada em Theodoro (2002), Soares (2008) e em Boudon (1979, p. 55) no sentido de que

Certamente que o processo de (re)organização institucional traz inerentes dificuldades na sua implantação, pois o grupo de atores envolvidos, sendo geralmente 
diversificado, impelirá disputas por representação e poder dentro das estruturas administrativas, uma vez que: "Como todo processo de organização supõe, bem entendido, que seja adotada uma distribuição definida de autoridade, esta resultará normalmente da resolução de conflitos entre os grupos interessados, e será necessariamente veículo de novos conflitos".

Nesse momento governamental brasileiro a postura era de centralização política onde a participação da sociedade civil era esparsa. Porém com a abertura de redemocratização a partir de 1985, e com o suporte de legislações ambientais mais inclusivas tais como a Política Nacional do Meio Ambiente (PNMA), $1981^{11}$ - paradoxalmente em pleno período ditatorial do governo de João Figueiredo (1979-1985), houve a emergência do modelo participativo ${ }^{12}$.

Ao mesmo tempo, neste documento é possível identificar que o conceito ambiental ainda não considera a inserção explícita da ordem social como um dos fatores de influência na gestão ambiental:

Art. $3^{\circ}$ - Para os fins previstos nesta lei, entende-se por:

I - meio ambiente, o conjunto de condições, leis, influências e interações de ordem física, química e biológica, que permite, abriga e rege a vida em todas as suas formas; (...)

Mais, somente no Art. $4^{\circ}$ tal fator é citado diretamente em toda a lei, ao salientar que

Art. $4^{\circ}$ - A Política Nacional do Meio Ambiente visará:

I - à compatibilização do desenvolvimento econômico-social com a preservação da qualidade do meio ambiente e do equilíbrio ecológico; (...)

Esse modelo teve como base a perspectiva (ou necessidade) da inserção das discussões da sociedade civil organizada e também com pressupostos jurídicos como o princípio do usuário poluidor-pagador (CAMPOS e FRACALANZA, 2010; PRESTE, 2000; CARNEIRO, ASSIS, 2012). Esses elementos tentaram possibilitar um controle tanto governamental quanto, destacadamente, social, com a inclusão da visão de longo prazo e de conflitos endogenamente processados (BOURLON e BERTHON, 1998; OSTROM, 1999; OSTROM 1993; THEODORO, 2002; COSTA, 2008). Enfim, o modelo participativo é um modelo onde os usos múltiplos dos recursos hídricos são mais estabelecidos, principalmente pela inclusão de instrumentos de gestão que possibilitem decisões ascendentes.

\footnotetext{
$11 \quad$ Machado (2003(a)); Pompeu (2010).

12 Considerado como "modelo sistêmico de integração participativa", de acordo com Campos e Fracalanza (2010).
}

Programa de Pós-graduação em Saneamento, Meio Ambiente e Recursos Hídricos da UFMG 
Simultaneamente, uma revisão de perspectiva de pesquisa a partir do nível de interação social e organizacional sobre os desenhos institucionais existentes a partir do final da década de 1980 e início da década de 1990 indicou mudanças. Esse momento histórico, ocasionado a partir do governo federal de Itamar Franco (1992-1994), sinaliza a proliferação do arcabouço jurídico-institucional para os recursos hídricos, confirmado primeiramente na Constituição Federal de $1988^{13}$.

Essa constituição se pautou não somente pela inclusão do meio ambiente como item específico no Art. 225, mas também por possibilitar a inclusão do princípio ambiental ao nível institucional. Destaca-se seu caput:

Todos têm direito ao meio ambiente ecologicamente equilibrado, bem de uso comum do povo e essencial à sadia qualidade de vida, impondo-se ao Poder Público e â coletividade o dever de defendê-lo e preservá-lo para as presentes e futuras gerações.

Tanto que em 1997, a Lei Federal 9.433, ao instalar a Política Nacional de Recursos Hídricos, modifica o cenário da gestão hídrica nacional em relação ao seu planejamento e supervisão institucional ${ }^{14}$, em seu "Art. $2^{\circ}$, Inciso VI - a gestão dos recursos hídricos deve ser descentralizada e contar com a participação do Poder Público, dos usuários e das comunidades.".

Ao mesmo tempo, porém, a ação das agências multilaterais internacionais que já existiam há algumas décadas na América Latina ficou ainda mais constantes e se tornaram parceiras para o financiamento de obras de infraestrutura (SWYNGEDOUW, 2005; SIMPSON e RINGSKOG, 1997). Foi o início de um movimento de atuação liberal frente às economias emergentes, porém com um discurso de aproximação entre o Estado e a sociedade civil via investimentos econômico-financeiros de larga escala.

O caso do CBHRV é um exemplo típico desse processo em que a negociação de interesses entre grupos distintos alcança um patamar que não era implantado nos modelos de gestão hídrica brasileiros ${ }^{15}$. O Estado assume (ou tenta assumir) um papel mais intermediário na regulação desse recurso de maneira a possibilitar uma gestão mais participativa e democrática.

\footnotetext{
$13 \quad$ Sob o governo de José Sarney (1985-1990).

14 Sob o governo de Fernando Henrique Cardoso (1995-2003).

${ }^{15} \mathrm{O}$ modelo participativo visa os usos múltiplos, de interesses difusos, com arenas de negociação via organismos de bacia mais consolidadas do que nos modelos anteriores.
}

Programa de Pós-graduação em Saneamento, Meio Ambiente e Recursos Hídricos da UFMG 
Apesar dessa realidade ainda não ser aquela estabelecida no cenário nem internacional nem nacional ${ }^{16}$, esse modelo pode ser refletido no aumento gradativo das Políticas e dos Planos Estaduais de Recursos Hídricos no país. No caso de Minas Gerais, cabe destacar a publicação da Lei Estadual n ${ }^{\circ}$ 13.199, de 1999, que trata especificamente da Política Estadual de Recursos Hídricos e também do Sistema Estadual de Gerenciamento de Recursos Hídricos (SEGRH-MG). Neste documento é colocado que

Art. $3^{\circ}$ - Na execução da Política Estadual de Recursos Hídricos, são observados: (...)

VIII - a compatibilização do gerenciamento dos recursos hídricos com o desenvolvimento regional e com a proteção do meio ambiente; (...)

Os modelos colocados podem ser analisados então a a partir de quatro dimensões principais:

1) Dimensão Institucional: Os modelos apresentam um gerenciamento institucional cada vez mais descentralizado, onde a participação da sociedade vai se tornando uma possibilidade real, ao menos em termos de participação e consulta. A mudança de posicionamento de um modelo de gestão descendente ("top-down") para um ascendente ("bottom-up") fez com que a dimensão institucional fosse na direção de um aumento de projetos de longo prazo:

De acordo com esse Modelo, em vez de configurar a mera execução despolitizada e técnica de decisões oriundas do topo do sistema político, a implementação consiste em um conjunto de estratégias criadas pela burocracia de nível de rua para a resolução de problemas cotidianos. Nesse sentido, os burocratas de âmbito local são os principais atores na entrega dos produtos de uma política pública. - Rua e Romanini $(2013,96)$.

Esses modelos ainda estão vinculados a um forte modelo burocrático-legalista, mas ao menos há atualmente (a partir dos anos 80s e 90s do século XX) uma maior flexibilidade para as organizações trabalharem entre si. Prova disso é que as arenas políticas se tornam mais amplas, com a inclusão explícita de ações conjuntas dos setores sociais, estatais e privados nos processos organizacionais de gestão.

Os organismos de bacia hidrográfica são agora a prova disso, ao menos como iniciativas a serem consolidadas institucionalmente. A incorporação de instrumentos

16 Com críticas a essa possibilidade de realização no curto prazo, como Swyngedouw (2005); Totti e Azevedo (2013), ou Silva (2015).

Programa de Pós-graduação em Saneamento, Meio Ambiente e Recursos Hídricos da UFMG 
de gestão também é identificada como suporte para uma institucionalização mais consolidada ao nível local. Também a possibilidade atual da cobrança pelos usos múltiplos dos recursos hídricos é vista com expectativa para um processo institucional de longo prazo nos locais onde foram implantadas (LISBOA, 2012; IGAM, 2016(a); $\mathrm{PIH}$, 2016). Melhor entender que

(...) a aplicação da cobrança pelo uso da água, apresentada como pilar econômicofinanceiro do novo sistema de gestão, pressupõe o fortalecimento dos órgãos gestores responsáveis pela emissão das outorgas de direitos de uso. (JOHNSSON e LOPES, 2003, p. 145).

A institucionalização passa a ser pensada menos como infraestrutura para o exercício das atividades previstas nos planos governamentais, e mais como locais para inserção social (BOURLON e BERTHON, 1998; BOSCARDIN, 2008). Mesmo que esta inserção ainda esteja em fase de criação ou consolidação de espaços e que não garanta uma real institucionalização das demandas sociais, é um cenário diferente do anterior, mais centralizado. E com a incorporação de câmaras técnicas de suporte à tomada de decisões dos comitês, é possível que haja um aumento na qualidade institucional envolvida nos processos de decisão dos mesmos, como tem sido visto em alguns (IGAM, 2015(b); JOHNSSON e LOPES, 2003; PNUD, 2015; GRANJA e WARNER, 2006).

2) Dimensão de Integração: É possível se verificar que um primeiro diferencial do modelo participativo é que, institucionalmente, há a determinação da gestão via bacia hidrográfica, nível mais local de planejamento. Foi um marco na reforma das políticas públicas pois se alicerçou tanto no preceito jurídico da Constituição Federal de 1988, como na Lei Federal n 9.433 de 1997, em seu já citado Art. $1^{\circ}$, mesmo número do Decreto Estadual n 41.578/2001, que salienta que

Art. $1^{\circ}$ - As bacias hidrográficas integram unidades físico- territoriais de planejamento e gestão no que se refere à formulação e implementação da Política Estadual de Recursos Hídricos, a cargo do Sistema Estadual de Gerenciamento de Recursos Hídricos - SEGRH-MG, na forma do disposto no inciso I e $\S 1^{\circ}$ do artigo 250 da Constituição do Estado e no artigo 32 da Lei no 13.199, de 29 de janeiro de 1999.

A questão da implantação gradual de sistemas de informações (ANA, 2013(a)) também merece atenção porque, tal como indica Biswas (2008), existem dificuldades que são exponenciais quando se pretende trabalhar de forma integrada em áreas muito 
diferentes entre si. Nesse sentido a organização de dados e informações é fundamental inclusive como ferramentas de planejamento e comunicação social (HARMONICOP, 2003).

O problema é que a sistematização administrativa ainda é incipiente e tanto em termos de recursos humanos e materiais há muito a ser consolidado. Todavia, hoje há uma integração de órgãos responsáveis pela gestão hídrica muito maior do que no modelo burocrático brasileiro do século XX. E com a incorporação de Planos Diretores de Recursos Hídricos, é possível que a integração possa minimamente acontecer entre os municípios participantes (CAMARGOS, 2005; CBHRV, 2015). Como há maior participação social do que antes, o nível de sinergia envolvida também é superior e tende a ser fundamental para impulsionar maior integração entre os membros do comitê, tanto interna quanto externamente (THEODORO, MARQUES, 2014; COSTA, 2008; ABERS, 2010) ${ }^{17}$. Mas é válido alertar que as políticas de gestão ambiental, em seus diferentes níveis e setores surgem em momentos históricos diferentes e nem sempre suficientes para uma visão integrada que evite agendas paralelas. Exemplos: a Política Nacional de Meio Ambiente (PNMA), 1981; Política Nacional de Recursos Hídricos (PNRH), 1997; Plano Nacional de Saneamento Básico (PLANSAB), 2007; Política Nacional de Resíduos Sólidos (PNRS), 2010; etc.

3) Dimensão Legal: comparativamente, os três modelos clássicos se basearam em uma crescente incorporação de normatizações de todos os níveis, o que tornou a gestão de recursos hídricos dotada de um arcabouço jurídico imenso e com áreas sobrepostas, fato alertado por alguns autores (LUCHINI, 2000; MACHADO, 2003(a); JÚNIOR, 2006; JOHNSSON e LOPES, 2003). Muito se deve a este fato à própria herança institucional-legal brasileira do modelo francês de base descentralizada, que enfrenta os mesmos problemas, porém lida com os mesmos de forma diferente (MACHADO, 2003(b); RICHARD e RIEU, 2008; FRANCE, 2014) - e que é apresentado mais adiante neste trabalho. Ao mesmo tempo, a legislação ambiental foi se modificando e ficando mais restritiva aos impactos ambientais dos empreendimentos licenciados. Porém apenas essa possibilidade não garante que grandes projetos de intervenção não sejam executados (HENKES, 2014; BONTEMPO et al., 2012).

\footnotetext{
17 Inclusive com “(...) a integração da gestão de recursos hídricos com a gestão ambienta (...)”, como orienta o Inciso III, do Art. $3^{\circ}$ da Lei Federal n 9.433/97.
}

Programa de Pós-graduação em Saneamento, Meio Ambiente e Recursos Hídricos da UFMG 
4) Dimensão Econômica-financeira: principalmente a partir do modelo participativo a incorporação dos investimentos necessários para a gestão, com suporte via cobrança, passou a ser considerado. É um avanço no sentido de passar ao comitê um poder de deliberação que antes era somente estatal pode indicar caminhos para processos futuros mais independentes dos contextos governamentais instáveis que a política partidária pode proporcionar. $\mathrm{Na}$ verdade, todos os instrumentos previstos na Lei Federal 9.433/97 indicam um ajuste entre as demandas sociais e as possibilidades da PNRH realizá-las economicamente. Isso é muito diferente, por exemplo, do modelo econômico anterior, onde a importância das pressões setoriais era maior do que as necessidades de investimentos demandadas pelas populações locais das bacias hidrográficas.

\subsection{Os contextos de análise das políticas públicas}

Para cada política pública há um contexto, uma situação de origem e de execução da mesma, e até quando não é finalizada, uma política pública diz muito sobre sua conjuntura história e institucional de existência. Na verdade, o campo das políticas públicas tem diversos conceitos em associação (atores sociais, transparência, capacidade de resposta, implementação, avaliação, etc) e várias correntes de pensamento. Por exemplo, SOUZA (2006) identificou ao menos nove modelos de formulação e análise de políticas públicas: 1) Tipologia da política pública; 2) Incrementalismo; 3) Os ciclos da política pública; 4) "Garbage can” ("Lata de lixo"); 5) "Advocacy coalition" ("Coalizão de defesa”); 6) Arenas sociais; 7) "Punctuated equilibrium" ("Equilíbrio interrompido"); 8) "Novo gerencialismo público" e 9) Neoinstitucionalismo.

Nesse trabalho são discutidos principalmente os itens sobre a tipologia da política pública (para caracterizar cada uma das possíveis maneiras com que uma política pública pode ser estruturada) e, principalmente, os ciclos de políticas públicas (para caracterizar as etapas de formação das políticas públicas e como foram formuladas e implantadas a partir dos contextos políticos e institucionais existentes).

Também devem ser consideradas as políticas públicas à luz das condicionantes sistêmicas nas quais elas são estabelecidas. Essas condicionantes podem ser consideradas, principalmente, como “(...) os processos socioeconômicos, políticos e culturais que estruturam e determinam em grande medida as opções de políticas públicas.”, tal como visto em Heller e Castro (2007,

Programa de Pós-graduação em Saneamento, Meio Ambiente e Recursos Hídricos da UFMG 
p. 285). Muitas vezes as condicionantes inerentes a cada processo de gestão institucional não são consideradas nas tomadas de decisões e consequências em termos de baixa qualidade e quantidade de ações realizadas podem acontecer.

Discutir sobre as condicionantes existentes nos fenômenos sociais, quando estes são pesquisados, é de fundamental importância na medida em que as escolhas políticas realizadas pelos atores sociais em interação têm um perfil próprio:

Quando falamos de condicionamentos sociais, pensamos, na maioria das vezes, na propriedade "social" deles. Uma realidade socialmente condicionada é aquela influenciada pela ideologia de forma intrínseca, porque não pode expelir objetivamente seu contexto político. Precisamente esta característica faz com que a aplicação dos esquemas lógicos das ciências naturais e formais se apliquem nas ciências sociais de maneira aproximada. A sociedade não é só forma; é antes de tudo conteúdo, história, possibilidade. (DEMO, 1985, p. 58).

Por exemplo, no caso brasileiro, condicionantes sistêmicas têm acontecido no país e modificado sua maneira de pensar seu desenho institucional tradicional (CUNHA, THEODORO, 2014; HELLER, CASTRO, 2007; OLIVEIRA, 2006). É de importância ressaltar que as referências condicionantes adiante são expostas de forma mais objetiva e geral, porém possuem características muito distintas e diferenciadas sobre a política de recursos hídricos. Cada uma dessas temáticas impactam os recursos hídricos em contextos institucionais e sociais particulares, demandando consequentemente leituras específicas sobre seus possíveis problemas e potencialidades:

I. Cenário internacional volátil, com grandes perdas econômicas e financeiras em seus mercados, com fortes impactos para economias em desenvolvimento, tal como ocorreu em 2008-2013, assim como para a gestão dos recursos hídricos (SIMPSON, RINGSKOG, 1997; BECK, 2009);

II. Crises políticas e institucionais no cenário partidário, que culminaram em diversos planos de ajustes fiscais, variações inflacionárias, déficits públicos com endividamento da máquina dos estados-federados. Houve também a abertura de processos de 2 impedimentos políticos presidenciais pós-regime ditatorial, sendo um finalizado em 1992, com Fernando Collor de Mello e outro em 2016, com Dilma Rousseff; 
III. Mudanças climáticas de altos impactos em algumas regiões do mundo (GIDDENS, 2010; PAQUEROT, 2005) e, no Brasil em particular, com o aumento de eventos de escassez hídrica (ANA, 2015(b)), que redefinem crescentemente a atuação científica e acadêmica (JURY e JR., 2005; NORGAARD, 1992; OSTRÖM, 1990);

IV. Novos atores, processos e lutas sociais que buscam uma maior democratização da atuação estatal, colocando em xeque o modelo burocrático-tecnicista tradicional de decisão e demandando um novo papel dos governos locais, regionais e federal (GRANJA, WARNER, 2006; EMPINOTTI, 2011; MENEGAT, 2002; MELLO, THEODORO, 2009; SILVA et al., 2000; SOARES, 2008; CAMPOS, FRACALANZA, 2010; UNU, 2014);

V. Continuação do desenvolvimento do arcabouço jurídico existente na direção de um maior controle das ações organizacionais das instituições, tais como leis vinculadas com a responsabilidade fiscal, social, ambiental concessões e licitações públicas. Cabe destacar ainda, o suporte que a Constituição Federal de 1988 proporciona a este prosseguimento legal via o fortalecimento do poder local, da intersetorialidade, o que não havia sido sequer estabelecido em normativas legais (HELLER, CASTRO, 2007; FREY, 2001; LISBOA, 2012; LUCHINI, 2000; MACHADO, 2003(a));

VI. A emergência de novos arranjos institucionais, com vários níveis intermediários de atuação para dar conta das novas demandas socioambientais em um cenário regional, nacional e mundial mais complexo por/com mais qualidade de governo (ROTHSTEIN, TEORELL, 2008; NEDER, 2002; ESMAN, UPHOFF, 1989; JÚNIOR, 2006; PARÉS, 2011; PRESTE, 2000; MMA, 2015).

Inicialmente, cabe destacar o que é considerada uma "política pública" enquanto um conceito teórico e prático empregado dentro das Ciências Sociais, destacadamente a Ciência Política. Esta deve ser entendida, por sua parte, justamente como a ciência que, baseada em uma argumentação racionalizada e objetiva, analisa os fatos da vida social tendo como pano de fundo as interações de poder e influência humana (BOBBIO, 2005; RIBEIRO, 2005; NOGUEIRA, 2004).

Como o campo de estudos sobre políticas públicas e gestão é muito vasto, é importante pontuar que existem diversas correntes de pensamentos sobre o tema que apresentam versões 
distintas entre si (RUA, ROMANINI, 2013; SOUZA, 2006; OLIVEIRA, 2006; FIGUEIREDO, FIGUEIREDO, 1986). Alguns autores se concentram em questões dos atores sociais e suas interações, outros sobre as instituições e suas ações formais, outros sobre as dimensões econômicas, por exemplo. Inclusive nota-se que as abordagens são modificadas ao longo do tempo, dadas as novas formas de interpretação dos fenômenos políticos e de suas interações frente ao Estado (MALUF, 2013).

De forma geral, as políticas públicas podem ser consideradas como todas aquelas que envolvem as ações e as formas de execução pelo governo, com consideração também aos tipos de resultados que são almejados, a partir da interação entre distribuição, regulação e redistribuição dos bens e serviços públicos (LOWI, 1964). Em resumo, elas têm por finalidade responder ao “(...) quem ganha o quê, por quê e que diferença faz.” (SOUZA, 2006, p. 24).

Mais ainda, valeria aqui o ponto levantado por Ansell e Gash (2007) de que as políticas públicas também podem gerar incentivos para a participação social crescer na medida em que resultados são apresentados e as partes interessadas são mais do que figurativas em suas participações, pois os resultados também são públicos, abrangentes.

Isto posto, as políticas públicas detêm algumas características essenciais para serem assim consideradas como ações políticas de ordem pública que geram impactos de diversos graus em atores sociais e instituições variadas (adaptado de SOUZA, 2006; OLIVEIRA, 2006; RIBEIRO, 2006):

São intencionais e com objetivos claros a serem alcançados, seja no curto, médio ou longo prazos. Tendem a ser de longo prazo pois buscam consolidar processos públicos que alcancem o maior contingente possível, mas podem também ocorrer no curto prazo, como as políticas distributivas (explicadas adiante);

Possuem etapas de realização que são consideradas como "ciclos de políticas públicas", onde há processos de formulação, implementação, execução e, mais recentemente incorporado, a avaliação das ações realizadas ${ }^{18}$.

18 O "policy cicle" é discutido adiante, com destaque para as discussões conceituais advindas do cientista político norte americano Theodoro J. Lowi, da Universidade de Cornell.

Programa de Pós-graduação em Saneamento, Meio Ambiente e Recursos Hídricos da UFMG 
São capazes de incluir grupos de interesses distintos, formados por atores sociais que têm níveis diferentes de formação, informação, participação. Têm a a capacidade de atuarem tanto em termos políticos (exercício de poder e influência) como também administrativos (normas, regras, execuções).

São multiníveis em termos de suas decisões e graus de impactos, causando eventuais conflitos de interesses que devem ser resolvidos também dentro de suas características processuais (possibilidade de expor opiniões e de negociar soluções consensuais).

Podem ser modificadas, ampliadas, reduzidas ou extintas quando demonstram não estarem adequadas ao pleno exercício dos interesses coletivos sob os quais foram formuladas.

Como citado, tanto por sua abrangência como por sua capacidade de influenciar o cotidiano individual e coletivo, as políticas públicas trazem em geral duas perspectivas de atuação, uma mais política e outra mais administrativa:

Perspectiva política: ressalta que há um processo decisório onde atores sociais e grupos de interesses diferentes interagem para tentarem resolver seus problemas da melhor forma possível. É uma percepção que só pode ser realmente concebida dentro de um "Estado Democrático de Direito", onde a consulta e participação pública é, mais do que uma iniciativa, uma necessidade para a garantia e avanços de direitos (JÚNIOR, 2006; MACHADO, 2003(a); MACKE e SARATE, 2015). Nessa perspectiva há espaço para os debates como também para os conflitos, o que força processos de negociação dos mesmos (SOARES, 2008; CAMPOS, FRACALANZA, 2010; CARNEIRO, ASSIS, 2012; GRANJA, WARNER, 2006). Essa perspectiva pensa a política pública como aquilo que o(s) governo(s) (municipal, estadual, federal), decidem implementar ou não ao coletivo, quem pode ou não ganhar seus benefícios e sob quais termos.

Perspectiva administrativa: tem uma relação com o planejamento e descrição das atividades que serão desenvolvidas para cada temática, a se contar também os investimentos econômico-financeiros, recursos humanos e materiais envolvidos. Envolve os níveis da gestão política estratégica (planos), tática (programas) e 
operacional (ações) (RUA; ROMANINI, 2013). Uma vez que ações consultivas foram feitas, acordos foram criados e deliberações foram acertadas (ROTHSTEIN, TEORELL, 2008; e, principalmente, SANDERSON, 2002), consequentemente as implementações das mesmas são executadas (CHIAVENATO, 2004; SOUZA, SCHUNEMANN, 2010). Essa perspectiva se encontra mais claramente identificada via as políticas de administração pública que são discutidas adiante como base organizacional para as outras políticas públicas.

As políticas públicas precisam também ser entendidas em razão de suas abrangências como políticas de Estado ou como políticas de governo. Tais concepções têm procedimentos próprios, por exemplo:

> Políticas de Estado $^{19}$ : Sendo o Estado como um ente direto das relações de obrigatoriedade condicionadas aos indivíduos (e também chamada de "sociedade política"), ele tem por finalidade a realização do "bem comum" para toda sua coletividade (DALLARI, 2005). Na mesma direção, sua função primeira é garantir a ordem pública e dar segurança aos seus indivíduos que, de sua tutela, não se emancipam jamais (AZAMBUJA, 2005; MACHADO, 2003(a)). E, de fato, nem poderiam, porque assim procedendo seria muito difícil a vida em sociedade. Assim, povo, território e governo devem ser desenvolvidos conjuntamente, ainda mais no chamado "Estado Moderno" de alta complexidade ${ }^{20}$, que tem por fundamento a democracia e a participação do maior número possível de indivíduos ${ }^{21}$, mesmo que em processos conflituosos:

As sociedades modernas têm, como principal característica, a diferenciação social. Isso significa que seus membros não apenas possuem atributos diferenciados (idade, sexo, religião, estado civil, escolaridade, renda, setor de atuação profissional, etc), como também possuem ideias, valores interesses e aspirações diferentes e desempenham papéis distintos no decorrer de sua existência. Isso faz com que a sociedade seja complexa e compreenda diferentes padrões de interação: cooperação, competição, conflito. (RUA; ROMANINI, 2013, p. 6).

19 O vocábulo "estado" é considerado aqui, com letra maiúscula ("Estado"), quando nos referimos ao poder institucional, sendo usado com letra minúscula quando está a significar alguma região brasileira, destacadamente os estados-federados componentes da República Federativa do Brasil.

${ }_{20}$ E que teve como antecedentes: Estado Antigo; Estado Grego; Estado Romano; Estado Medieval, a partir de Dallari (2005) e Maluf (2013).

Ou, segundo BOBBIO (2007, p. 26): “A vida de um Estado moderno, no qual a sociedade civil é constituída por grupos organizados cada vez mais fortes, está atravessada por conflitos grupais que se renovam continuamente, diante dos quais o Estado, como conjunto de organismos de decisão (parlamento e governo) e de execução (o aparato burocrático), desenvolve a função de mediador (...)”.

Programa de Pós-graduação em Saneamento, Meio Ambiente e Recursos Hídricos da UFMG 
O Estado só pode ser entendido como uma pessoa jurídica de direito público internacional (JÚNIOR, 2006), com a função primeira da legislação de regras que possam nortear o comportamento coletivo, como a aplicação dos seus tipos de políticas públicas (vistas adiante).

Assim, o Estado é “(...) a organização político-jurídica de uma sociedade para realizar o bem público, com governo próprio e território determinado.”, de acordo com AZAMBUJA (2005, p. 9). Um problema é que, como alerta (BOBBIO, 2007 e JÚNIOR, 2013), o Estado é caraterizado por possuir relações de subordinação entre governantes e seus governantes, o que, caso não seja respeitado em seus limites mutuamente acordados, pode resultar em restrições de acesso aos bens e serviços estatais. Em síntese, o que caracteriza a política de Estado é que ela permanente, pois é anterior e posterior aos diferentes governos que a representam, sendo deles independente para suas deliberações.

Políticas de governo: as políticas de governo são aquelas que refletem o contexto histórico em que estão inseridas, assim como também os arranjos institucionais que foram formados para cada temática e sua consequente decisão. Também possuem um arcabouço legal que as fundamenta tanto ao nível constitucional federal quanto estadual. Como são mais susceptíveis aos processos de negociação partidária, alianças e parcerias institucionais ${ }^{22}$, as políticas de governo se relacionam muito com a capacidade de articulação dos seus representantes no sentido da conjunção de ações juntos aos pares e à população em geral. Além disso, nas políticas de governo o poder executivo tende a decidir de forma mais rápida e direta do que nas políticas de Estado, pois tem um aspecto de atuação muito ligado ao plano administrativo.

É observado que as temporalidades, forma de atuação e cadeia de decisão entre as políticas de governo e as políticas de Estado são distintas e não podem ser consideradas como no mesmo âmbito na gestão institucional, porém devem ter atuação conjunta. Tanto que, como a própria presidência do CBHRV para o período 2013-2017 salienta em CBHRV (2015(b)):

\footnotetext{
${ }^{22}$ No caso do CBHRV, especificamente sobre o tema da possibilidades de parcerias, tal situação é prevista na Deliberação Normativa $n^{\circ}$ 01/2002 que "Estabelece normas para a celebração de convênios de parcerias entre municípios ou entidades da sociedade civil organizada e usuários das águas da bacia do Rio das Velhas, objetivando implementar ações do Plano Diretor desta Bacia.".
}

Programa de Pós-graduação em Saneamento, Meio Ambiente e Recursos Hídricos da UFMG 
O sistema atual necessita de gestão em diversos níveis, os quais precisam estar alinhados. Demanda-se políticas de Estado, e não só de governo. O planejamento e as soluções precisam extrapolar quatro anos. É praticamente obrigatório que se tenha uma projeção de futuro, ao invés de uma execução do presente, danosa para o meio ambiente, por que diz do que vamos destruir, o que vamos usar e não o que iremos preservar, como tem ocorrido atualmente.

Porém é necessário distinguir que as políticas públicas não são todas iguais em seus conceitos e finalidades. Elas se destinam a ações mais direcionadas do que uma leitura superficial pode supor pois tentam resolver questões com atribuições distintas entre si, mesmo que interligadas. Inclusive, cada vez mais autores têm salientado que toda política social é uma política pública, mas nem toda política pública é uma política social.

Essa diferenciação se deve ao fato de que as políticas públicas vinculadas ao campo social se começaram a ser discutidas a partir da segunda década do século $\mathrm{XX}$, devido às graves crises econômicas acontecidas. Foi um cenário que colocou a forma de atuação liberal em cheque, o que propiciou a releitura desta, com fundamento nas políticas do "Welfare State", ou o "Estado de Bem-Estar Social", sendo também chamada como "Estado Providência" ou "Estado Social". Por ela, a macroeconomia é vista sob a ótica da necessidade da agência de um Estado como elemento fundamental para o sucesso das políticas públicas de um país.

Ela foi implantada como verificação dos limites que um mercado capitalista desregulado (OFFE, 1997) possui e dos impactos que o mesmo gera quando cada indivíduo ou grupo busca apenas o seu próprio benefício, e não coletivo. Pois quando isso acontece, efeitos perversos na ordem social são cada vez maiores (HIGGINS, 2011), ao mesmo tempo que demandam mais estudos sobre suas influências. (BOUDON, 1979). O posicionamento do bem estar social continuou até a década de 1970, onde houve a emergência dos pensadores neoliberais, que passaram a questionar se realmente o Estado teria condições de gerenciar e intervir adequadamente na economia e garantir os ganhos dos vários grupos de interesses envolvidos.

Cabe destacar que o reconhecimento sobre a capacidade/necessidade de políticas públicas intervirem positivamente na qualidade de governo (ROTHSTEIN e TEORELL, 2008) tem sido cada vez mais, principalmente a partir do início do século XXI. Uma das razões é que os Estados modernos têm enfrentado crises cada vez maiores e mais recorrentes, e a atuação 
mínima desses para a manutenção da qualidade de vida de suas populações tem sido considerada importante (GIDDENS, 2010; HALL, 2001).

De forma geral as políticas públicas são organizadas como adiante: (RUA e ROMANINI, 2013; FIGUEIREDO e FIGUEIREDO, 1986; TREVISAN e BELLEN, 2008):

1) Políticas Sociais: tradicionalmente relacionadas com os campos da segurança alimentar; saúde (prevenção/recuperação); educação (planejamento letivo, inserção e manutenção de contingentes); habitação; assistência social (reparação e/ou implementação de benefícios); ações afirmativas (implementação e/ou avaliação de sistemas de cotas; questões de gênero; acessibilidade; questão indígena; novos movimentos sociais, etc). São as primeiras políticas públicas a serem consideradas em uma agenda governamental na medida em que são pertinentes às necessidades mais básicas de uma população, o que torna a garantia das mesmas se torna um imperativo $^{23}$.

2) Políticas de Infraestrutura: são direcionadas para o fornecimento de condições materiais e humanas para a realização das atividades sociais de curto, médio e longo prazos (principalmente este último), tendo como base os recursos ambientais em geral. São tais como saneamento básico, drenagem urbana, transportes marítimos e terrestres em geral, tratamento de resíduos sólidos, geração de energia (área de grande destaque no Brasil e precursora para o arcabouço legal ao gerenciamento hídrico nacional, como explicado adiante).

São políticas muito sensíveis às variações cambiais e têm, no decorrer histórico brasileiro, sido desenvolvidas quando há um bom cenário de investimentos setoriais internacionais.

Interessante notar que, de acordo com Jury e Jr. (2005), seria justamente nas políticas de infraestrutura, de pequena escala, uma saída para países em desenvolvimento conseguirem melhores resultados na gestão de seus recursos naturais, com o aumento da eficiência do controle e alocação dos mesmos.

23 PNUD, 2015.

Programa de Pós-graduação em Saneamento, Meio Ambiente e Recursos Hídricos da UFMG 
3) Políticas Econômicas: vinculadas com geração de emprego e renda; incentivos aos setores industriais e de consumo; procedimentos de controle e/ou ajustes fiscais; controle da moeda e/ou ajustes de contextos inflacionários; controle cambial; incentivos ao setor produtivo agrícola. Têm um grande histórico de aplicação no Brasil, uma vez que o país atravessou períodos de crises econômicas de larga magnitude, antes e depois de sua redemocratização política e social. Foram principalmente utilizadas nos anos 80 s e 90 s, no período da busca por estabilidade monetária e da captação de investimentos externos na economia nacional ${ }^{24}$.

4) Políticas de Administração Pública: são aquelas responsáveis pela implantação de sistemas de informações; banco de dados institucionais diversos; planejamento, execução e avaliação de planos, programas e projetos governamentais; parcerias institucionais de âmbito nacional e internacional, inclusive as parceiras público$\operatorname{privadas}^{25}$; desenvolvimento de recursos humanos (principalmente) e materiais, além dos procedimentos de arrecadação pública que são devidamente estabelecidos pelo sistema legislativo nacional. Elas dão a base para a atuação das outras políticas públicas no sentido de seu planejamento, organização, organização e até mesmo avaliação de performance, quando possível. Para o segmento socioambiental pode significar a (re)organização do setor em bases mais participativas, menores impactos à natureza e com a emergência de desenhos institucionais mais adequados a cada necessidade ${ }^{26}$.

Como se identifica, políticas públicas são mesmo amplas, mas, por outro lado, um fato importante também a ser pontuado é que nem todas as políticas públicas são governamentais. Ao contrário, afirmar tal possibilidade é negar os diversos movimentos sociais e inclusive do setor privado, que têm desenvolvidos atividades que são de benefício de parte ou de toda uma população (principalmente quando acontecem em pequenos municípios). Parcerias entre comunidades e empresas particulares são cada vez mais recorrentes, mesmo que para tentar

\footnotetext{
24 Esse cenário de busca por capitalização das políticas públicas brasileiras será muito importante para o aquecimento de projetos institucionais vinculados ao meio ambiente e aos recursos hídricos em particular, tal como aconteceu no caso do Comitê da Bacia Hidrográfica do Rio das Velhas no final dos anos 90s.

25 A título de exemplo, e em consideração a parcerias em termos institucionais, a DN do CBHRV 07/04, de 10 de dezembro de 2004 preve a celebração de Termos de Cooperação Técnica.

26 Como salienta Manikutty (1997), os projetos e desenhos institucionais devem ser minimamente flexíveis para permitir a existência de modificações advindas do conhecimento e experiências locais (inclusive do próprio projeto).
}

Programa de Pós-graduação em Saneamento, Meio Ambiente e Recursos Hídricos da UFMG 
sanar problemas de ordem muito específica, como recuperação de área degradada ou mesmo pequenas iniciativas para geração de emprego e renda (BISWAS, 2008). Por outro lado, há também a possibilidade das parcerias entre os entes públicos e entidades qualificadas como "Organizações da Sociedade Civil de Interesse Público", o que é explicitamente colocado na Lei Federal o Capítulo II ("Do Termo de Parceria"), em seu Art. 9:

Fica instituído o Termo de Parceria, assim considerado o instrumento passível de ser firmado entre o Poder Público e as entidades qualificadas como Organizações da Sociedade Civil de Interesse Público destinado à formação de vínculo de cooperação entre as partes, para o fomento e a execução das atividades de interesse público previstas no art. $3^{\mathrm{o}}$ desta Lei.

Assim, tanto ao nível privado como também da sociedade civil, e, destes juntos entre si ou juntos com as ações do Estado, é possível atualmente a criação de ambientes propícios para as práticas das políticas públicas. Outrossim, esses ambientes podem se configurar como organizações além das ações estatais já estabelecidas e com mais autonomia entre os atores sociais participantes (SWYNGEDOUW, 2005).

Esses movimentos de integração entre diferentes atores sociais em ações que seriam anteriormente aos anos 80s e 90s (principalmente) e redefinem os espaços coletivos (VIOLA e FERREIRA, 1996; REIGOTA, 1998; GIDDENS, 1991). Certamente que esse tipo de atuação é paralelo ao tipo de atuação estatal, podendo se tornar ação suplementar ao mesmo (de modo adicional, acessório, que ultrapassa ao todo), mas não complementar ao Estado (a completar o que falta). Pois se tal prática se torna corriqueira, pode-se perder a capacidade de responsabilização do Estado em suas tarefas obrigatórias em termos de bens e serviços. A própria Constituição Federal determina tal postura em várias de suas passagens, tais como:

Título II (“Dos Direitos e Garantias Fundamentais”), Capítulo I ao Capítulo V, Art. 5 ao Art. 17;

Título III (“Da Organização do Estado"), Capítulo VII (“Da Administração Pública"), Art. 37 ao Art. 43;

Título VIII (“Da Ordem Social”), Capítulo I ao Capítulo VIII, Art. 193 ao Art. $232^{27}$.

27 Com destaque para, para este trabalho, o Capítulo VI ("Do Meio Ambiente"). 
São itens, assim como a Constituição Federal como um todo, que vão na direção da universalização dos bens e serviços, da inclusão do maior contingente possível de indivíduos a participarem da vida coletiva, da agenda pública. Enfim, de pertencerem verdadeiramente a um país com base na república ("res publica": "coisa pública") ${ }^{28}$ e na federação (estados independentes, porém não autônomos) brasileira, em um longo caminho ainda a ser consolidado, mesmo com vários avanços institucionais e legais (AZAMBUJA, 2005; DALLARI, 2005).

Esses avanços, no caso brasileiro, têm acontecido pelo reconhecimento gradual - e à custa de muitos debates - da diversidade dos grupos sociais existentes, seja por seus pontos de vista, suas necessidades atuais e futuras (criança e adolescentes, e de forma destacada, a questão ambiental, por exemplo). É um movimento até certo ponto tardio, devido aos processos históricos de aumento da desigualdade que o país possui, e que se refletem também no domínio discursivo e prático sobre meio ambiente.

Essa integração entre as políticas públicas é um desafio a ser atingido no cenário brasileiro, que conta com uma população tão diversificada quanto suas demandas (ALMEIDA, 2007), o que chama orienta uma responsabilidade e sensibilidade de atuação muito grande dos gestores públicos. Igual ao que indica Wostl e Kranz (2010), existem falhas nos processos de gestão de políticas públicas justamente pela negligência da complexidade da dimensão humana, de sua diversidade. E isso aconteceria justamente pela pouca compreensão dos gestores sobre processos de governança (do “como" esses processos ocorrem).

\subsection{Os tipos de políticas públicas}

É válido explicar que as políticas públicas não devem ser consideradas também como genéricas, com potencial de atuarem em qualquer campo da sociedade que quiserem e de forma indiscriminada. Longe disso, elas possuem graus de impactos que devem ser considerados ao serem formuladas. Basicamente, são divididas em 4 grupos de atuação (FREY, 2000; RUA e ROMANINI, 2013 e, principalmente, LOWI, (1964), mas vale alertar que existem abordagens variadas sobre tal, a depender da perspectiva de análise:

\footnotetext{
28 A república, segundo BOBBIO (2007), se caracteriza “(...) pelo controle público do pode e, na idade moderna, pela livre formação de uma opinião pública (...). ’.
}

Programa de Pós-graduação em Saneamento, Meio Ambiente e Recursos Hídricos da UFMG 
1) Políticas constitutivas: são aquelas que dão as condições gerais sob as quais são negociadas as políticas distributivas, redistributivas e regulatórias, ou melhor, lidam com procedimentos. São consideradas por vários autores (FREY, 2000; RUA e ROMANINI, 2013) como políticas estruturadoras - inclusive para outras políticas públicas posteriores. Elas são capazes de formular e alterar as regras políticas estabelecidas sob as quais outras decisões são tomadas, como indica Souza (2006).

Como exemplos, tem-se: determinações regimentais dos espaços legislativos; regras constitucionais em geral; sistema político-administrativo.

2) Políticas distributivas: baixo grau de conflito, pois têm um grande número de incluídos em suas ações, o que gera consenso e indiferença amigável. São aquelas onde há a disponibilização de bens e serviços estatais, com atuação geralmente vinculada com áreas de educação, saúde, segurança, defesa, saneamento básico, habitação etc. Por estarem incluídas em diferentes frentes, essas políticas têm rotina de decisões normalmente desagregadas, assim como seus custos, que são difusos, o que gera baixa grau de conflito entre os seus contribuintes (LOWI, 1964).

De forma geral, as políticas distributivas são aquelas onde há um direcionamento da ação estatal para clientelas específicas. Caso as políticas distributivas não estejam inseridas em um plano governamental maior e mais complexo elas podem se tornar apenas ações assistencialistas, o que pode gerar também dificuldades de coalizões políticas e sociais futuras (OLSON, 1999; OFFE, 1997). Essa é uma preocupação constante para o caso brasileiro, com forte histórico de se atear a políticas distributivas que tornam assistência social continuada e não mecanismo de mudança social. Sendo um tema de alerta tanto em autores (FIGUEIREDO e FIGUEIREDO, 1986; OLIVEIRA, 2006), como na própria população brasileira (ALMEIDA, 2007).

Como exemplos podem ser citados: pavimentação de ruas; programas (recorrentes) e projetos (pontuais) de emprego e renda; suporte a eventos contingenciais (enchentes, secas, catástrofes, etc).

3) Políticas redistributivas: Têm como característica uma proposta de correção das desigualdades existentes, o que acaba por orientá-las ao conflito dos grupos de interesses, pois redistribuem recursos diversos, mas também direitos e valores 
sociais/morais. São consideradas como criadoras de divisões sociais e econômicas porque são bancadas por aqueles com maior capital e com usufruto dos extratos sociais de baixa renda (OFFE, 1997). Ao mesmo tempo, são percebidas como direitos sociais que atingem um contingente maior de grupos sociais e podem diminuir desigualdades estruturais (MENEGAT, 2002).

O fato é que ao inserirem novas formas de acessos aos recursos governamentais, as políticas redistributivas alimentam debates que podem resultar em conflitos de longo prazo que dificultam a integração das políticas públicas no geral. Mas mesmo que consideradas como políticas que causam divisões de classes e/ou categorias sociais de acordo com LOWI (1964) ${ }^{29}$, e em algumas discussões de OFFE (1997), por outro elas são importantes de existir por propiciar uma recuperação mínima de algumas camadas da população frente a processos de desigualdade social elevada, como é o caso brasileiro (FREY, 2000; LUCHINI, 2000). Principalmente quando é pensado o nível de diferenciação existente no acesso aos serviços públicos essenciais (HELLER e CASTRO, 2007; CARNEIRO, ASSIS, 2012; GARSON, 2009).

Como exemplos, tem-se: modificação no sistema de arrecadação de impostos para setores sociais carentes; programas de renda mínima; realocação de recursos orçamentários; reforma agrária; sistema previdenciário e previdenciário etc.

4) Políticas regulatórias: que são as ordens, proibições, decretos e portarias existentes de controle institucional, que geram consensos ou conflitos conforme a configuração específica das políticas. Comporta o contexto da legislação que vai ordenar as políticas distributivas e redistributivas, orientando o comportamento da dimensão legal das políticas públicas. Tem como premissas a busca pela eficácia (fazer o que tem de ser feito, conceito quantitativo), eficiência (fazer da melhor forma o que tem de ser feito, conceito qualitativo) e a efetividade (mudança de realidade, com permanência dos resultados obtidos) ${ }^{\text {nas }}$ políticas públicas. São políticas que podem (re)desenhar institucionalmente os governos porque estabelecem regra que podem melhorar os bens e os serviços públicos.

29 São políticas consideradas como de "soma-zero", ou melhor: “(...) onde uma das partes ganha todos os beneficios e a outra perde todos os beneficios e arca com todos os custos, na mesma proporção." (RUA e ROMANINI, 2013).

Programa de Pós-graduação em Saneamento, Meio Ambiente e Recursos Hídricos da UFMG 
Consequentemente, por ser de focada no princípio da normalização do comportamento institucional e coletivo, encontra grande ligação inerentemente ao meio socioambiental ${ }^{30}$. Salienta-se que as políticas regulatórias são de efeito de longo prazo e sem a vinculação com benefícios imediatos, pois normalmente são resultados de diversas etapas de estudos e negociações setoriais para a criação dos diversos marcos regulatórios. São assim pensadas para dar estabilidade ao sistema público em todas os seus níveis (social, infraestrutura, administrativo e econômicos).

Como exemplos, tem-se: legislação ambiental (lei do uso do solo, recursos hídricos, resíduos sólidos, etc); regulação tarifária em geral (residencial, industrial, setorial); instituições jurídicas etc.

A pensar a questão dos recursos hídricos em particular, o aproveitamento dos mesmos é organizado e/ou controlado por meio de políticas regulatórias, inclusive pelo fato de seu reconhecimento como bem dotado de valor econômico, limitado e de domínio público (Art. $1^{\circ}$, incisos I e II da Lei Federal 9.433/97). Depois, porque demandam um nível de interação muito grande entre suas organizações participantes, o que normaliza a forma como as mesmas devem atuar em conjunto para uma gestão integrada.

\subsection{A análise de políticas públicas}

A análise de políticas públicas surgiu a partir da década de 1950 nos Estados Unidos, como proposta de campo do conhecimento dedicado a pesquisas de cunhos setoriais, com pouca ou nenhuma vinculação ao contexto macro institucional (FIGUEIREDO e FIGUEIREDO, 1986; FREY 2000; SOARES, 2008; SOUZA, 2006) ${ }^{31}$. Mas esse posicionamento acabou por se tornar um problema ao seu desenvolvimento, uma vez que é fundamental que haja processos de avaliação e contextualização das políticas públicas de forma a melhorá-las na direção de suas capacidades de intervenção e resposta, como salienta Sanderson (2002) e principalmente Figueiredo e Figueiredo (1986).

\footnotetext{
${ }^{30}$ No caso brasileiro essa classificação das políticas públicas de meio ambiente enquanto políticas regulatórias demonstra ser procedente. Pois o país é regido em uma base constitucional onde a segurança da efetividade desse direito incumbe diretamente (mas não totalmente, visto a participação democrática ampla) no poder público. Esta premissa é verificada no Art. $225, \S 1^{\circ}$, que contém sete diferentes ações que o Estado deve realizar para a manutenção da qualidade ambiental brasileira.

31 Cabe salientar que Souza (2006, pg 23) indica que "Antes disso, registra-se a contribuição inicial de Harold Lasswell que, em 1936, criou a expressão "policy analysis" (análise de política pública) "como forma de conciliar o conhecimento científico/acadêmico com a produção empírica dos governos e também como forma de estabelecer o diálogo entre cientistas sociais, grupos de interesse e governo".
}

Programa de Pós-graduação em Saneamento, Meio Ambiente e Recursos Hídricos da UFMG 
No Brasil, as pesquisas sobre análise e avaliação de políticas públicas podem ser consideradas como recentes e ainda em consolidação como prática para o conhecimento ampliado da dimensão social (MACKE e SARATE, 2015) e ambiental do país (PEREIRA, HELLER, 2015; RIBEIRO, 2015; THEODORO, 2014). Ou mesmo na inserção de análises/avaliações na agenda pública (ARRETCHE, 1996; TREVISAN, BELLEN, 2008; FIGUEIREDO, FIGUEIREDO, 1986; FREY, 2012; CUNHA, THEODORO, 2014):

A pesquisa de avaliação é ainda incipiente no Brasil. A avaliação de políticas sociais desenvolveu-se apenas nos anos 80 e, mesmo assim, de forma desigual entre os diferentes tipos de políticas sociais. Essa assimetria revela-se não só no número de estudos produzidos e o número de programas que são objeto de avaliação, como também no que diz respeito à sua sistemática, ou seja, na utilização ou não de critérios explícitos de avaliação e de uma metodologia específica e apropriada ao critério empregado." (FIGUEIREDO; FIGUEIREDO, 1996, p. 118).

Normalmente os trabalhos versam sobre o distanciamento que ocorre entre os planos, programas e projetos concebidos, suas implantações e possíveis benefícios públicos que os mesmos trouxeram em suas localidades de aplicação. É uma realidade que indica que leituras adaptadas aos cenários dos países em desenvolvimento deverão ser cada vez mais consolidadas, de forma a possibilitar o descobrimento de soluções para os problemas próprios dessas regiões. Mas sobre essa situação cabe o alerta de que deve-se distinguir que "plano", "programa" ou "projeto" não são sinônimos de "planejamento", e sim, partes distintas do processo de planejamento em si (PMI, 2015; SOUZA, SCHUNEMANN, 2010; CHIAVENATO, 2004). O que significa que somente a existência de um plano institucional (como, por exemplo, o Plano Nacional de Recursos Hídricos) não garante, em termos de análise de uma política pública, que ela é ou será atuante. O que é preciso é que haja uma concertação política envolvida, o que quer dizer que existam acordos minimamente aceitos entre governos e parceiros sobre procedimentos institucionais e operacionais, realizados a partir de espaços de interação.

De forma geral pode-se pensar em "planos" quando estão em destaque os conceitos, as matrizes que regem um determinado tema e dão as linhas gerais de atuação sobre o mesmo. São as estratégias institucionais. Já os "programas" podem ser considerados como aqueles em que há um sentido de coordenação das várias ações devidamente separadas por objetivos de atuação. São as táticas institucionais. E finalmente os "projetos" são definidos como “(...) um esforço temporário para criar um novo produto, serviço ou resultado exclusivo.” (PMI, 2015). São as atividades operacionais. $\mathrm{O}$ fato é que tem sido um desafio para o cenário institucional 
nacional conseguir fazer interagir esses conceitos de maneira corrente (OLIVEIRA, 2006), mesmo nas iniciativas mais recentes (THEODORO, ANDRADE e LANA, 2013; SISEMA, 2015; CASTRO et al., 2015).

\subsubsection{Tipos de análises de políticas públicas}

A retomar as questões conceituais, as análises de políticas públicas encontram suas fundamentações na ciência política em termos de investigações que discutem, em termos gerais, sobre:

1) questionamentos clássicos sobre os sistemas políticos;

2) as forças políticas e os processos decisórios;

3) os resultados produzidos em um dado sistema político (tais como as políticas setoriais ambientais e sociais, dentre outras). Para isso uma tipologia da análise de políticas públicas, que coloca em discussão diversos aspectos da prática dos procedimentos de concepção e tomada de decisões, cabe destacar alguns pontos em particular, que seriam as principais perspectivas existentes. Elas representam os exercícios possíveis de poder (relação central na ciência política em si e também nas políticas públicas como campo de estudo) em esferas diferenciadas que já são consolidadas na literatura sobre o tema político público (RUA; ROMANINI, 2013). Consequentemente, temos os seguintes tipos conceituais existentes atualmente:

$>$ "Polity" = trata de como o poder político é organizado em uma dada sociedade. Ela se ocupa da ordem do sistema político, delineada pelo sistema jurídico e pela estrutura institucional existente (e que é criada a partir do sistema político-administrativo); também já considerado como o "Estado politicamente organizado", como em March e Olsen $(2008)^{32}$. Para o caso brasileiro, por exemplo, significa o arcabouço jurídico

\footnotetext{
32 A trazer aqui a pertinente colocação dos tradutores do documento de March e Olsen (2008): “A palavra polity vem da palavra grega "politéia", termo de significado incerto. Uns definem-na como todo e qualquer tipo de ordem política, exceto a tirania (que não é ordem política), outros como um tipo específico de ordem política, a república. Poderia ser traduzida como "sistema político", "ordem politica", "instituições políticas" ou "organização política"; contudo, os correlatos desses termos em inglês aparecem no original - political system, political order, political institutions e political organization -, dificultando a tradução de polity por quaiquer um deles. Assim, cremos que a expressão "Estado politicamente organizado" transmite com precisão o conceito (N.T.)."
}

Programa de Pós-graduação em Saneamento, Meio Ambiente e Recursos Hídricos da UFMG 
macro, onde está localizada a Constituição Federal, as leis nacionais ${ }^{33}$ e as normas delas advindas, dentre outros exemplos possíveis. A polity regula a vida política do país como um todo, como na determinação do sistema federalista, formas de determinação e participação dos poderes executivo, legislativo, judiciário e como as interações institucionais podem ser feitas (União, estados, municípios).

> "Politcs" = que visa discutir os conteúdos e as deliberações políticas, ou melhor, se ocupa com o processo político em si, das ações políticas via atores sociais e políticos. Na verdade, este nível de poder é colocado em ação no cotidiano do fazer político. Para alguns autores, é aqui identificado o nível da competição política para a determinação dos poderes de cada ator participante (sindicatos, partidos, associações etc) em busca de sua afirmação perante os outros participantes também interessados em colocarem seus interesses como os mais relevantes em cada questão a ser debatida $^{34}$.

$>$ "Policy" = refere aos programas políticos, aos problemas de caráter técnico e também ao conteúdo das decisões políticas; são as políticas públicas a serem propostas e implementadas. É a política pública propriamente dita ${ }^{35}$, pois é aqui tratada a ação tipicamente de Estado sobre a sociedade como um todo. Mais ainda, nas policies é possível uma maior identificação das opções de atuação que perpassa cada Estado e seus respectivos governos, pois são as escolhas de intervenção feitas pelos mesmos.

$\mathrm{Na}$ verdade, as experiências empíricas a serem demonstradas têm indicado a inter-relação entre essas três formas de análise e não uma relação linear entre estrutura política (polity) que influencia as negociações políticas (politics) que influenciam o resultado (policy). Assim, não há uma autonomia completa de cada um dos termos, pois, caso fosse assim, haveria uma falta completa de interação na realização da ação política como um todo. Essa interação se assemelha ao posicionamento de Lowi (1964, p. 21) de que: "Uma relação política [political relationship] é determinada pelo tipo de política [policy] que está em jogo, de modo que, para todo tipo de política [policy], é provável que haja um tipo distinto de relação política.".

\footnotetext{
33 Tais como a Lei Federal $n^{\circ}$ 9.433/97, que orienta a gestão dos recursos hídricos brasileiros.

No caso dos organismos de bacia existentes, as reuniões plenárias, reuniões de Câmaras Técnicas, audiências públicas, consultas públicas (tais como orçamento participativo), aprovação de Planos Plurianuais de Aplicação representam instantes onde a politics pode ser vista em ação.

35 Assim, a política pública enquanto ação e conceito, “(...) permite distinguir entre o que o governo pretende fazer o que, de fato, faz." - Souza (2006).
}

Programa de Pós-graduação em Saneamento, Meio Ambiente e Recursos Hídricos da UFMG 
Não é sem sentido que o mesmo autor vê na policy um instrumento de análise e avaliação central de Estado, governo e sociedade, pois ela é “(...) capaz de mobilizar reações de vários atores, baseadas numa avaliação antecipada sobre como aquela política afetará os seus respectivos interesses." (RUA; ROMANINI, 2013, p. 36).

Com relação à esta afirmação ela faz sentido com as colocações de Abers e Keck (2013, p. 64), que salientam o caráter da interação na concepção das políticas públicas, dando-lhes direcionamentos variados e até mesmo contraditórios:

(...) os ideais de políticas públicas cresceram de uma combinação de debates entre especialistas (nos quais ideiais contestadoras eram defendidas), embates politicos (nos quais os ideais que não eram específicos da comunidade de especialistas eram foram incluídas nas discussões), e experimentos práticos in lugares particulares. Isso ajuda a explicar porque desenhos institucionais podem acabar ambiguous e contraditórios internamente."

Mais ainda, quando se considera o meio ambiente e suas políticas públicas de intervenção, por exemplo, é identificado que o mesmo levou a modificações no arranjo institucional estatal e privado, com a emergência de novos atores a reestruturar o processo político como um todo. Nesse sentido, se há uma “(...) dinâmica expressiva das estruturas institucionais, deve-se partir do pressuposto da existência de uma dependência, pelo menos parcial, entre as políticas a serem examinadas e a variável institucional ”- Frey (2000, p. 218).

Já as políticas públicas de recursos hídricos, especificamente para o caso do CBHRV, se comportam ora como "políticas regulatórias" (que podem gerar consensos ou conflitos a partir do uso de decretos, portarias etc), ora como "políticas constitutivas" (políticas estruturadoras) de ação (CORTES e LIMA, 2012; FREY, 2000; MENEGAT, 2002). Nesse sentido as Meta 2010 e Meta 2014 podem servir como exemplo, ao terem sido incorporadas dentro da lógica estatal do governo mineiro, em seu eixo estruturador. Elas visaram um novo desenho institucional ao campo da gestão de recursos hídricos. De certa forma, as ações realizadas pelo Banco Mundial em relação aos países em desenvolvimento seguiram esse modelo, chamado de "institutional building" (GOLDSMITH, 1992), com vistas ao aumento de processos de gestão participativa.

Cabe destacar tais características uma vez que, de forma geral, pesquisas de cunho analítico e/ou avaliativo sobre recursos hídricos costumam ser de duas formas:

Programa de Pós-graduação em Saneamento, Meio Ambiente e Recursos Hídricos da UFMG 
1) Análise e/ou avaliação de processos: onde o foco é o de desenvolver teorias que demonstrem como foram realizadas as etapas de implantação de uma dada política pública. Melhor, visa entender o início-meio-fim, a "politics" envolvida na construção de uma "policy".

2) Análise e/ou avaliação de impactos: onde o foco é o de desenvolver teorias que demostrem quais foram os efeitos, diretos, indiretos, perversos ou não ${ }^{36}$, de uma dada política pública. Melhor, visa compreender o ex-post facto da "policy" pretendida.

Nessa pesquisa, a escolha é uma análise dos processos político-institucionais relacionados ao CBHRV, no sentido de se identificar se os pressupostos da gestão democrática, participativa e integrada foram implementados, total ou parcialmente, de acordo com as diretrizes concebidas, a se salientar suas principais restrições e potencialidades de atuação ${ }^{37}$.

\footnotetext{
36 Higgins (2011).

Algo próximo ao colocado por Figueiredo e Figueiredo (1986, p. 107): "Na análise de políticas públicas os cientistas políticos têm se preocupado, essencial e tradicionalmente, em estudar como as decisões são tomadas: que fatores influenciam o processo de tomada de decisões e as características desse processo.".
}

Programa de Pós-graduação em Saneamento, Meio Ambiente e Recursos Hídricos da UFMG 


\title{
4 MÉTODOS
}

\subsection{O recorte de pesquisa}

A questão de destaque que aparece quando se deseja pesquisar sobre qualquer objeto em particular é aquela que remete ao "como" fazer um recorte metodológico e a partir do mesmo, poder realizar generalizações, comparações e indicações para futuras intervenções (DÉSVEAUX e FORNEL, 2012; MINAYO, 2012; e, destacadamente, DESLAURIERS, 1991). Como estrutura a tornar essa possibilidade de uma leitura comparada possível, a escolha realizada foi no sentido de analisar a coleta de dados e documentos relacionados com a gestão do CBHRV, com base qualitativa, uma vez que

\begin{abstract}
A palavra qualitativa implica uma ênfase sobre as qualidades das entidades e sobre os processos e os significados que não são examinados ou medidos experimentalmente (se é que são medidos de alguma forma) em termos de quantidade, volume, intensidade ou frequência. Os pesquisadores qualitativos ressaltam a natureza socialmente construída da realidade, a natureza socialmente construída da realidade, a íntima relação entre o pesquisador e o que é estudado, e as limitações situacionais que influenciam a investigação. Buscam soluções para as questões que realçam o modo como a experiência social é criada e adquire significado. (DENZIN, 2006, pg 23).
\end{abstract}

Também é possível nessa direção mensurar se o alcance do comitê acontece por suas ações internas administrativas/deliberativas ou por fatores externos à sua competência (política governamental regional e nacional, intervenções dos setores privados, financiamentos estruturais etc), fato que pode permitir uma compreensão maior também sobre a gestão ao nível de bacia hidrográfica.

A ideia é a de se destacar quais são as principais práticas desses organismos de bacia, e quais suas características comuns em razão do que conseguir avançar no gerenciamento dos seus recursos humanos e materiais. Além disso, os aspectos relacionados com seus arranjos políticos e institucionais são colocados como pontos de base para a análise da possível construção de políticas públicas interativas. Consequentemente, a escolha da análise documental se mostrou a mais adequada aos intentos comparativos colocados nesse trabalho.

\subsubsection{Fontes de pesquisa}

Por se tratar de uma pesquisa de base descritiva, que explica os fenômenos em sua ocorrência nas realidades dos fatos, no cotidiano das práticas já estabelecidas e também aquelas em

Programa de Pós-graduação em Saneamento, Meio Ambiente e Recursos Hídricos da UFMG 
discussão, o uso de fontes primárias de informação se tornou algo de importância para dar legitimidade de análise. Assim, foram incorporadas informações primárias advindas da pesquisa de campo, de entrevistas realizadas a partir de um roteiro sobre temas vinculados com a gestão hídrica. Na mesma sequência, foi definida a utilização de fontes secundárias onde diversas fontes de dados oficiais, dos setores públicos e privado. Foi seguida uma lógica de seleção bem próxima do que discute Yin (2010, p. 73):

As fontes de evidência discutidas aqui são as usadas mais comumente na realização dos estudos de caso: documentação, registros em arquivos, entrevistas, observações diretas, observação participante e artefatos físicos. Entretanto, você deve reconhecer que uma lista completa de fontes pode ser bastante extensa - incluindo filmes, fotografias e fitas de vídeo; técnicas projetivas e testes psicológicos; proxêmica, cinésica; etnografia de "rua"; e história de vida (...).

Inicialmente é válido caracterizar que para a realização da presente pesquisa foram selecionados alguns recortes de ordem metodológica para a análise das políticas públicas existentes no estudo de caso já referido. Elas visaram dar uma estrutura de pesquisa baseada em:

1) Seleção de ordem histórica-legal: A pesquisa se orientou a discutir desde os modelos institucionais implantados no país a partir da década de 1930 até as definições normativas e legais relativas à gestão de recursos hídricos com términos em 2012.

2) Seleção de ordem geográfica: São observadas as políticas públicas relativas aos recursos hídricos vinculados com a bacia hidrográfica do Rio das Velhas, que perpassa 51 municípios delimitados em Plano Diretor de Recursos Hídricos próprio.

3) Seleção de ordem documental: Como base para suporte ao material empírico, foram selecionadas as fontes de informações oriundas da legislação e administração pertinente ao sistema de gestão de recursos hídricos nacional e regional, a ver:

Leis e decretos estaduais: principais legislações no âmbito do estado de Minas Gerais foram selecionadas por indicarem os limites e estrutura institucional do sistema estadual de gestão ambiental em uso. A destacar (CBHRV, 2015(d)): Lei Estadual n 13.199/99 (dispõe sobre a Política Estadual de Recursos Hídricos); Decreto Federal n 46.636/14 (contém o Regulamento do Instituto Mineiro de Gestão das Águas (IGAM), revisado; Lei Estadual n ${ }^{\circ}$ 
21.972/16 (dispõe sobre o Sistema Estadual de Meio Ambiente e Recursos Hídricos (SISEMA); Decreto 39.692, de 29 de junho de 1998, referente à criação do CBHRV; Decreto Estadual $\mathrm{n}^{\circ}$ 44.046/05 (regulamenta a cobrança pelo uso de recursos hídricos de domínio do Estado); Deliberação Normativa do Conselho Estadual de Recursos Hídricos (CERH/MG) $\mathrm{n}^{\circ}$ 06/02 (que estabelece as Unidades de Planejamento e Gestão de Recursos Hídricos do Estado de Minas Gerais); Deliberação CERH/MG n 260/10 (aprova o Plano Estadual de Recursos Hídricos de Minas Gerais).

$>\quad$ Leis e decretos federais: principais legislações no âmbito de atuação do Estado brasileiro que, a lembrar, segue um caráter federalista de atuação institucional. Nesse sentido, a principal orientação sempre remete à Constituição da República Federativa do Brasil. E aliam-se a ela vários outros decretos e resoluções de âmbito nacional que influenciam na gestão mineira, consequentemente. A destacar: Decreto Federal n 24.643/34 ("Código das Águas"); Lei Federal n 9.433/97 (institui a Política Nacional de Recursos Hídricos e cria o Sistema Nacional de Gerenciamento de Recursos Hídricos); Lei Federal n 9.984/00 (dispõe sobre a criação da Agência Nacional de Águas (ANA)); Decreto n ${ }^{\circ}$ 4.613/03 (regulamenta o Conselho Nacional de Recursos Hídricos);

> 2 Planos Diretores de Recursos Hídricos (PDRH): são considerados como os pilares dos direcionamentos da gestão relativa ao Rio das Velhas, sendo a primeira versão de 2005 (CAMARGOS, 2005) e a segunda, relativa à sua atualização (CBHRV, 2015(a)). Em ambos os resumos executivos, a questão de como desenvolver os instrumentos da PNRH são discutidos, inclusive em temos de cenários de utilização dos usos múltiplos, crises e escassez hídrica, ações participativas, etc.

3 Moções do CBHRV: realizadas em situações muito específicas, tais como as que foram realizadas sobre redução de área de proteção; sobre proteção de mananciais permanentes; sobre evento de rompimento de barragem de eventos.

62 Deliberações Normativas do CBHRV (2002-20012): documentos relativos desde a criação de subcomitês e possíveis alterações dos mesmos, processos de outorga de grande extensão, contratos de gestão entre o comitê e sua agência de águas, regimento interno e possíveis alterações ao mesmo, metodologia da cobrança, etc. A destacar a Deliberação Normativa 03, de 30 de março de 2010 (Regimento Interno do CBHRV), que delimita toda a 
dinâmica de estruturação e funcionamento do comitê, inclusive suas competências e formas de atuação dos membros.

> 69 Atas de Reuniões: compreendendo desde o início do comitê até o ano de 2012, esses documentos são relevantes para o entendimento do cotidiano das tomadas de decisões do comitê e dos organismos de bacia envolvidos como um todo. As atas ajudam na composição das narrativas que foram formadas após anos de reuniões e interações entre os membros do CBHRV, assim como as principais decisões formadas e tomadas nas plenárias. As plenárias, inclusive, são uma determinação contida no Regimento Interno do CBHRV, que orienta que

Art. 23. O CBH-Velhas reunir-se-á:

I - ordinariamente, seis vezes ao ano, em data, local e hora fixados com antecedência de, pelo menos, 10 (dez) dias;

II - extraordinariamente, por iniciativa do Presidente ou da maioria de seus membros, convocada com antecedência mínima de 5 (cinco) dias.

Nesse sentido, as atas indicam que a frequência das reuniões foi seguida no período estudado, a ver: 2001: 13 reuniões; 2002: 05 reuniões; 2003: 03 reuniões; 2004: 05 reuniões; 2005: 06 reuniões; 2006: 06 reuniões; 2007: 06 reuniões; 2008: 05 reuniões; 2009: 05 reuniões; 2010: 05 reuniões; 2011: 06 reuniões; 2012: 06 reuniões. Cabe destacar que dentre as atas, em 2005 foi publicada a Ata de Constituição da Associação de Usuários Pró-Gestão das Águas da Bacia Hidrográfica do Rio das Velhas (ASSUVE) e, em 2007, foi publicada a Ata de Fundação da Associação Executiva de Apoio a Gestão de Bacias Hidrográficas Peixe Vivo (AGBPV).

Relevante é o fato de que os processos de outorga foram muito citados durante as entrevistas com lideranças e também nas observações realizadas nos trabalhos de campo como muito "cartoriais", cheia de procedimentos para liberação e, o que seria pior, bem pouco fiscalizada. E tal conjunto de fatores poderia também ser um fato de desestímulos aos usuários passíveis de outorga para seguirem o caminho legal administrativo adequado, o que é lembrado por um entrevistado do segmento de usuários: "O comitê de bacia é vinculado diretamente aos recursos hídricos e a outorga é um exemplo sui generis em Minas Gerais, pois o CBH Velhas dá liberação ou não para alguns empreendimentos e isso é muito contestado, sabe...".

Mas cabe destacar que o procedimento previsto está um pouco mais explicado por um representante do poder público municipal, ao afirmar que “(...) o IGAM é que tem posição de

Programa de Pós-graduação em Saneamento, Meio Ambiente e Recursos Hídricos da UFMG 
poder de outorga, de dizer se pode ou não pode. O comitê só referenda ou não. Concorda ou não.". De fato, o CBHRV atua nesse sentido de referência ao tomador de decisão institucional, mas isso não impede de que recursos às decisões tomadas não sejam possíveis aos possíveis outorgados de solicitarem vistas às suas demandas no próprio comitê, no IGAM e no Conselho Estadual de Recursos Hídricos.

Para a lida com a situação de planejamento institucional é indispensável que o mesmo seja incorporado dentro da gestão de recursos hídricos para que as possíveis lacunas operacionais existentes (tais como desorganização do sistema, baixa eficiência dos instrumentos de gestão, dentre outros) sejam diminuídas.

Para isso se tornar realidade, as políticas públicas hídricas devem, por exemplo, considerar o aumento da criação de cenários de atuação institucional, com pouco ou muita demanda pelos usuários, em suas práticas de planejamento. O problema é que no contexto atual, essa atuação por cenários ainda é pouco desenvolvida na gestão hídrica, sendo relativamente recente suas aplicações (OLIVEIRA, 2006; TOTTI e AZEVEDO, 2013; TREVISAN e BELLEN, 2008).

4) Seleção das entrevistas das entrevistas: 26 lideranças vinculadas direta ou indiretamente aos processos de tomada de decisão do CBHRV, realizadas ao entre dezembro de 2013 e fevereiro de 2014, com contatos eventuais de revisão entre dezembro de 2015 e fevereiro de 2016.

5) Seleção de ordem institucional: Para a análise da gestão de recursos hídricos via o estudo de caso do CBHRV, foram selecionados os seguintes mandatos de diretoria (para o período entre 1998-2012).

○ 1998-1999: João Israel Neiva ${ }^{38}$

○ 2000-2002: Eleição: Paulo Maciel Jr. (Engenheiro de Telecomunicações ${ }^{39}$ )

○ 2003-2007: Apolo Heringer Lisboa $\left(\right.$ Médico $^{40}$ ) - 1 reeleição;

○ 2008-2012: Rogério Sepúlveda (Engenheiro Civil ${ }^{41}$ ) - 1 reeleição;

$38 \quad$ Não foi identificada a formação deste representante em nenhuma ata de reunião. O mesmo foi

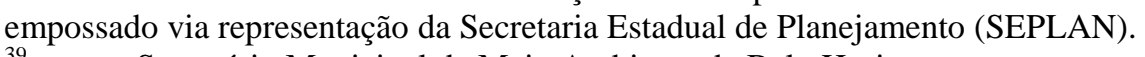

39 Secretário Municipal de Meio Ambiente de Belo Horizonte.

$40 \quad$ Representando o Instituto Guaicuy, que é a figura jurídica do Projeto Manuelzão.

Programa de Pós-graduação em Saneamento, Meio Ambiente e Recursos Hídricos da UFMG 
Como foram discutidos alguns assuntos contingenciais aos conflitos e dinâmicas institucionais, eventualmente o mandato do comitê para 2013-2017: sobre presidência de Marcus Vinícius Polignano (Médico ${ }^{42}$ ), foi citado.

\subsubsection{Sobre o controle na observação participante da pesquisa}

Quando é analisada a proposta aqui colocada da análise da gestão de recursos hídricos via um estudo de caso específico, deve ficar clara a opção pela utilização de contínuo trabalho de campo que, posteriormente, deve encontrar respaldo no arcabouço intelectual de discussão. O campo aqui é considerado de fundamental importância enquanto estratégia, uma vez que

Le concept de champ permet aussi de comprendre comment les stratégies individuelles et collectives s'insèrent dans un espace de contraintes intériorisées par les agents sous la forme de manières de penser, de faire, de juger. Un même espace peut toutefois opposer plusieurs goups qui doivent orienter l'action. (DÉSVEAUX e FORNELL, 2015, p. 43).

Deve ficar clara também a opção, em termos metodológicos, da observação participante e não da pesquisa-ação como forma de inserção no grupo pesquisado (CBHRV). Isso porque na primeira tem-se uma opção pela participação via observação dos fatos sociais selecionados (reuniões técnicas e/ou culturais; eventos científicos e/ou acadêmicos, etc), o que YIN (2010) chama de observação "do" participante e possui como ponto forte ser discernível às características e aos motivos interpessoais.

Está é uma postura diferente da perspectiva de tentativa de intervenção na realidade que se estuda, própria da pesquisa-ação. Apesar de haver discussões de que cada vez mais a pesquisa social estaria sendo redefinida como pesquisa-ação, como demonstrado em DENZIN e LINCOLN (2006), em termos de que para alguns autores “(...) a pesquisa social é aplicada, ou não será uma pesquisa.", a pesquisa não se coloca dentre os argumentos de um posicionamento ativista de atuação. Porém, deve ficar claro que na observação participante não há um posicionamento estático, passivo, não-influenciável, no que cabe a explicação de YIN (2010, p. 98):

A observação participante é uma modalidade especial de observação na qual você não é simplesmente um observador passivo. Em vez disso, você pode

\footnotetext{
$41 \quad$ Instituto Guaicuy.

$42 \quad$ Instituto Guaicuy.
}

Programa de Pós-graduação em Saneamento, Meio Ambiente e Recursos Hídricos da UFMG 
assumir vários papéis na situação de estudo de caso e participar realmente nos eventos sendo estudados.

Ao contrário, foram adotados durante a pesquisa procedimentos de afastamento do pesquisador em relação às suas participações nas reuniões e/ou eventos relacionados com o objeto de pesquisa para possibilitar uma análise consistente em relação à interpretação das práticas e, principalmente, narrativas colocadas pelos entrevistados selecionados. Tal postura concorda com as colocações de BECKER (1997, p. 33) sobre os problemas inerentes ao trabalho de campo enquanto inserção do pesquisador:

Um problema que aflige quase todos os pesquisadores - pelo menos todos aqueles que tentam estudar, por qualquer método, organizações, grupos e comunidades do mundo real - é se inserir: conseguir permissão para estudar aquilo que se quer estudar, ter acesso às pessoas que se quer observar, entrevistar ou entregar questionários. O problema é perene para os praticantes de observação participante, que habitualmente têm que negociar a questão novamente a cada vez que entram numa organização, pois será a primeira vez que algum sociólogo o terá feito.

Nesse sentido, foram tomadas consequentemente algumas medidas para aumentar a confiabilidade mútua entre pesquisador e objeto de pesquisa, a ver:

1) Saída do pesquisador das atividades como membro do CBHRV a partir do ano de 2012

2) Foco inicial na análise documental dos processos administrativos e institucionais do comitê ao invés das entrevistas propriamente ditas, de forma a poder atuar de forma crítica quando da realização destas via a bagagem de leitura anterior feita;

3) Acompanhamentos eventuais sobre o CBHRV, basicamente em reuniões plenárias, mas sem a realização de entrevistas ou conversas com os membros de forma constante e somente na condição de pesquisador e não mais como membro - somente anotações de campo de caráter individual;

4) Saída do pesquisador como membro da Câmara Técnica de Planos, Programas e Projetos do CBHSF, durante o ano de 2013; 
5) Realização das entrevistas apenas a partir do final do ano de 2014 e início de 2015, quando já havia se passado mais de dois anos de afastamento das funções do comitê, o que possibilitou entender com mais isenção os conflitos e processos de tomadas de decisões.

Essas ações em conjunto criaram condições de menor bias na relação entre pesquisador e entrevistados, o que é considerado fundamental em pesquisas de cunho qualitativo e onde o estudo de caso envolve muitas perspectivas de funcionamento. Isso encontra respaldo nas discussões de ALAMI et al. (2010, p. 70) quando os autores salientam que

Uma pesquisa qualitativa exige do pesquisador uma adaptação ao campo. (...) $\mathrm{O}$ pesquisador depende das pessoas que interroga. Ademais, certos fatores pessoais - sua identidade, por exemplo - podem influenciar a realização de um estudo. Em função das situações da pesquisa, o status do pesquisador produzirá efeitos na coleta das informações em termos, por exemplo, de cumplicidade ou de concorrência entre o pesquisador e as pessoas interrogadas, ou de proximidade e distância em relação ao tema. Assim, a proximidade cultural de um pesquisador com as pessoas por entrevistar pode servir de facilitador para penetrar em uma comunidade, mas poderá igualmente constituir um filtro negativo se ela não permite um distanciamento eficaz dos fatos observados.

Como resultado, houve um trânsito tranquilo do pesquisador tanto nas pesquisas de campo como também na realização das entrevistas, inclusive nos momentos de contatos posteriores à primeira entrevista para checagem de informações (por exemplo: relações conflituosas; instrumentos de gestão, etc).

\subsection{A "triangulação de métodos" como metodologia de análise}

Para o desenvolvimento da pesquisa aqui proposta, a utilização de uma única metodologia ou técnica se revelou desde o início insuficiente para dar conta de se criar um arcabouço conceitual e explicativo de vários fenômenos encontrados no cotidiano da gestão de recursos hídricos que, em si, são difusos e complexos em termos de sua operacionalização. Consequentemente, da mesma forma como que o gerenciamento de recursos materiais, humanos e naturais não se dá de forma direta e unilateral, a capacidade de compreensão das características e demandas de cada um dos meios envolvidos na temática hídrica (física, biótica e principalmente, antrópica) também é multifacetada.

Para se conseguir assim a identificação dos elementos fundamentais de inferência sobre a temática da gestão dos recursos hídricos e, consequentemente, possibilitar a sua análise da 
maneira mais ampla possível, optou-se aqui pela escolha da aplicação do que Minayo et. al. (2005) indicaram como a "triangulação de métodos".

Isso significa que há um direcionamento claro para a obtenção de informações a partir de fontes as mais múltiplas possíveis. Essas várias fontes de geração de informações podem ser tanto do campo institucional, legal, administrativo e cultural relacionado ao objeto de estudo, o que tende a permitir uma legitimidade maior nas discussões que são produzidas, principalmente quando é tratada uma perspectiva qualitativa de estudo. Esse posicionamento é visto tanto em NELSON et al. (1992), como, principalmente, em YIN (2010, p. 134), ou seja:

Com a triangulação dos dados, os problemas potenciais de validade do constructo também[em podem ser abordados, porque as múltiplas fontes de evidência proporcionam, essencialmente, várias avaliações do mesmo fenômeno. Sem provocar surpresa, uma análise dos métodos de estudo de caso descobriu que os estudos de caso que usavam múltiplas fontes de evidência tinham classificação superior, em termos de sua qualidade geral, aos que contavam apenas com fontes únicas de informação.

Essa análise se ancora aqui nesta pesquisa objetivamente pela:

constituição de uma bagagem documental qualitativa adequada ao estudo proposto;

a inserção da pesquisa ao redor de um trabalho de campo ao nível dos locais e arenas de discussão relacionadas com o que se almeja descobrir;

a aplicação de entrevistas individualizadas com as principais lideranças envolvidas direta ou indiretamente com o tema da gestão de recursos hídricos (no caso, lideranças em termos sociais, institucionais, acadêmicos e afins).

Isto significa que a triangulação de métodos é colocada aqui enquanto uma estratégia de investigação voltada para a combinação de métodos e técnicas que possibilitem uma leitura mais ampliada dos cenários sociais e institucionais envolvidos com objeto a ser analisado. De forma objetiva ao método proposto vale salientar que, de acordo com Bauer e Gaskell (2008, p. 198),

Triangulação é um conceito que vem do interacionismo simbólico e é desenvolvido, dentro dessa corrente, primeiramente por Denzin (1973), significando a combinação e o cruzamento de múltiplos pontos de vista; a tarefa conjunta de pesquisadores com formação diferenciada; a visão de vários informantes e o emprego de uma variedade de técnicas de coleta de dados que 
acompanha o trabalho de investigação. Seu uso, na prática, permite interação, crítica intersubjetiva e comparação.

O próprio processo de condução da pesquisa pela aplicação de triangulação de métodos é em si uma abordagem diferenciada das usuais em recursos hídricos e gestão. Usualmente as análises de campo, documental e de entrevistas são realizadas separadamente e os aspectos qualitativos envolvidos nos processos de gerenciamento são pouco desenvolvidos. Porém, deve-se destacar que apesar de possibilitar a leitura de várias técnicas e ampliar o escopo de identificação de limites ao desenvolvimento da gestão hídrica via estudo de caso, a triangulação não pode ser considerada uma inovação metodológica no campo científico. Ao contrário, ela tem uma bagagem histórica dentro do campo científico que já consolidou seu emprego, principalmente a partir do final da década de 1990 e início dos anos 2000 (MINAYO, 2012).

Principalmente em estudos interdisciplinares, que enfrentam inerentes restrições em utilizar apenas um tipo de técnica de coleta de dados, a utilização mais ampliada de instrumentos de captação de informações, formais e informais caminhou gradativamente ao crescimento da complexidade da busca por explicações mais completas para áreas como as das pesquisas ambientais (NORGAARD, 1992), estudos de casos (GIL, 2009) ou de políticas públicas (SAETREN, 2005; NOORDEGRAAF; NEWMAN, 2011), para dar somente alguns exemplos.

\subsection{Caracterização e justificativa da escolha dos entrevistados}

A principal preocupação para que a coleta das informações e dados advindos dos respondentes fosse consistente e passível de confrontação e análises futuras tanto pela equipe desta pesquisa como por avaliadores externos foi a seleção atenta ao rol dos entrevistados. Eles deveriam ser significativos o suficiente para poderem compreender com tranquilidade o conjunto de questões existentes no roteiro de entrevista, como também estarem vinculados, direta ou indiretamente à temática da gestão de recursos hídricos como um todo.

O caminho natural para tais escolha foi de fazer uma opção pela questão da liderança, do perfil de indivíduos que tomam a ponta das situações de diálogos intersetoriais e que, mais, conseguem trazer seus pares também ao debate, em um processo de fortalecimento mútuo já discutido tanto em Abers et al. (2004), Ansell e Gash (2007), e, mais recentemente, Lisboa (2012) e Abers (2013). Consequentemente, a seleção de lideranças não pode ser justificada

Programa de Pós-graduação em Saneamento, Meio Ambiente e Recursos Hídricos da UFMG 
simplesmente pela presença constante das mesmas em listas de atas de reuniões (apesar de que isto foi feito durante a pesquisa, vide CBHRV, 2012), mas também pela forma e conteúdo participativo transmitidos do decorrer do estudo.

O cuidado na delimitação dos respondentes também pode ser creditado ao termo descrito por Becker (1997, p. 42) como a "hierarquia de credibilidade" na composição das narrativas que são coletadas e pesquisadas em termos de estruturas organizacionais/institucionais que possuem hierarquização em algum sentido (tal como acontece em um sistema de tomada de decisão, tal como o que acontece na área ambiental):

(...) uma característica da estrutura de qualquer organização estratificada é que os representantes comuns da sociedade rotineiramente atribuem maior credibilidade à história contada por aqueles que a administram do que às histórias daqueles que estão nos níveis inferiores na hierarquia. Esta hierarquia de credibilidade parece-me ser um traço característico de todas as organizações hierárquicas.

E mesmo se o pesquisador apresentar o outro lado de uma dada situação, pode também ser acusado de bias pela inversão desta hierarquia de credibilidade, ao favorecer a narrativa dos subordinados às estruturas de poder existentes. No caso da pesquisa, a ampliação dos respondentes, de todos os segmentos e com lideranças (administrativas, técnicas, jurídicas, sociais) internas e externas ao sistema de gestão de recursos hídricos foi uma aposta na diminuição possível do bias metodológico inerente à mesma. Assim, as entrevistas com as lideranças foram relativas aos segmentos que participam de forma direta ou indireta na gestão hídrica do Rio das Velhas, seja como membro ou ex-membro; assessoria técnica, executiva ou de pessoal, assim como usuários dos serviços e público acadêmico.

Foram considerados todos os segmentos constituintes do comitê, porém alguns contatos não foram transformados em entrevistas por falta de retorno ou agenda de outras possíveis lideranças. Apesar de haver, como salienta Abers (2010), a questão da relativa pouca (porém, ao mesmo tempo crescente) representação das mulheres frente à importância da temática hídrica, foram entrevistadas no tema, foram entrevistadas 10 lideranças dos sexo feminino e 15 lideranças do sexo masculino.

Isso totalizou as 26 entrevistas aqui apresentadas, de forma anônima em termos de respondente e de forma pública em termos de cargos e/ou representação institucional, tal como ficou acertado junto aos entrevistados. Finalmente, a "policy network" (JOHNSSON e LOPES, 2003) relacionada ao CBHRV não sofreu alterações significativas no decorrer da 
pesquisa, o que permitiu um contato relativamente constante com o conjunto de respondentes que foram selecionados.

\subsection{A "análise de conteúdo" como marco referencial para análise de entrevistas}

Atualmente, abordagens mais integradas, com agregação dos aspectos tecnológicos mais os aspectos gerenciais têm crescido em produção e vão à direção de discussões sobre gestão participativa, políticas públicas, direitos de acesso aos recursos hídricos, redes de trabalho etc (TOTTI e AZEVEDO, 2013; SAETREN, 2005). Isso indica que essas abordagens discutem de forma mais abrangente mecanismos técnicos e sociais para a gestão, o que corrobora a proposta da pesquisa aqui apresentada.

A permear este esforço de cognição entre restrições e possibilidades existentes à gestão, tomou-se como plano metodológico a "análise de conteúdo" (BARDIN, 1994, CAMPOS 2004) sobre estes três contextos de relação documentos-campo-entrevista, uma vez que, majoritariamente, a pesquisa possui um caráter qualitativo que pode ser perdido quando apenas um desses tópicos é trabalhado (MELLO e REZENDE, 2014).

Mais ainda, a utilização da metodologia de uma análise de conteúdo demonstrou suavizar a interface entre pesquisador e entrevistados (CORTEZ, 1998; MANZINI, 2012) na medida em que estes se mostraram acessíveis a responderem perguntas de várias temáticas, uma vez que, como indica Bauer e Gaskell (2008, p. 203), “A análise de conteúdo é uma construção social” e consequentemente permite tais situações de troca de informações e experiências.

Mesmo que não tivessem familiaridade com algum tema específico, em algum outro momento era possível aos mesmos compensarem tais lacunas com explicações mais detalhadas naqueles pontos que eram mais familiares a eles. Com esse recorte de intervenção, a intenção foi a de permitir à pesquisa se cercar do maior número possível de suportes teóricos e práticos para o entendimento de um trabalho que tem como objetivo a descoberta de processos de tomada de decisões onde a governança é não apenas descrita em sua forma operacional, mas explicada em suas instâncias de interação.

Ao mesmo tempo, a análise de conteúdo tem uma possibilidade de descobrir narrativas próprias a cada segmento participante do modelo de gestão por comitê de bacia, mesmo que a 
estrutura/ambiente da relação perguntas-respostas possa ser diminuída (BAUER e GASKELL, 2008). Algo próximo do que indica Yin (2010, p. 33):

As entrevistas são conversas guiadas, não investigações estruturadas. Em outras palavras, embora seja observada uma linha de investigação consistente, a verdadeira corrente de questões, na entrevista de estudo de caso, será provavelmente fluida, não rígida.

Como salientado por Minayo (2012), as fases do processo científico de pesquisa foram aqui realizadas e alicerçadas de forma a se ter uma pesquisa que conjugasse a fase exploratória, com o trabalho de campo (participações em reuniões ordinárias e extraordinárias, eventos, câmaras técnicas, etc vinculadas diretamente aos temas de tese propostos; entrevistas realizadas com as lideranças previamente selecionadas) para se fundamentar adequadamente rumo às análises e tratamentos do material empírico e documental.

Tais entrevistas com lideranças (e cujo roteiro aplicado se encontra nos Apêndices) que participam dos momentos de negociação e propostas podem gerar a visualização de formas de interpretação dos processos sociais e institucionais envolvidos (OLIVEIRA, 2006; HAGUETTE, 2000; MANZINI, 2012; GIL, 2008), principalmente através de seus códigos sociais de conduta, narrativas históricas e interpretação de mundo (BARDIN, 1994; MELLO e REZENDE, 2014).

Justifica-se a utilização de entrevistas para se possibilitar análises de conteúdo das discussões/opiniões das lideranças selecionadas, visto que elas representam as versões dos atores sobre os fatos observados, construindo narrativas institucionais e próprias. Essas diferenciações entre as técnicas de coletas de dados que foram selecionadas são apresentadas no Quadro 4.1, de forma a apresentar os pontos fortes e fracos que cada uma delas (técnicas) apresenta, assim como as formas com que foram empregadas durante a presente pesquisa para explicarem os fatos da gestão estudada sob a perspectiva democrática, integrada e participativa. 
Quadro 4.1: Técnicas de coleta de dados selecionadas

\begin{tabular}{|c|c|c|c|}
\hline Técnica de Coleta & Pontos Fortes & Pontos Fracos & Metodologia \\
\hline $\begin{array}{l}\text { Observação } \\
\text { Direta }\end{array}$ & $\begin{array}{l}\text { - Pode captar o comportamento } \\
\text { natural das pessoas } \\
\text { - Minimiza a influência do desejo de } \\
\text { nivelamento social e técnico } \\
\text { - Possui nível de intromissão } \\
\text { relativamente baixo } \\
\text { - Confiável para observações com } \\
\text { baixo nível de inferência para } \\
\text { pesquisa e tomada de decisões }\end{array}$ & $\begin{array}{l}\text { - É polarizada pelo observador } \\
\text { - Requer treinamento especializado para } \\
\text { manter nível baixo de interferência } \\
\text { - Não garante o anonimato } \\
\text { - Pode interferir no comportamento do } \\
\text { entrevistado } \\
\text { - Não comprova/esclarece o observado } \\
\text { - Possui número restrito de variáveis }\end{array}$ & $\begin{array}{l}\text { - Utilização da "observação participante" como } \\
\text { um dos mecanismos de coleta de dados através da } \\
\text { participação em diversos momentos do CBHRV } \\
\text { ou de instituições ou acontecimentos relevantes } \\
\text { para a pesquisa. }\end{array}$ \\
\hline $\begin{array}{l}\text { Pesquisa } \\
\text { Documental }\end{array}$ & $\begin{array}{l}\text { - Tem baixo custo } \\
\text { - Permite a redução do tempo de } \\
\text { obtenção } \\
\text { - Contém informação estável } \\
\text { - Pode ser realizada em várias fontes } \\
\text { físicas e virtuais }\end{array}$ & $\begin{array}{l}\text { - Pode trazer dados que se mostram } \\
\text { incompletos ou desatualizados } \\
\text { - Dados podem estar muito agregados } \\
\text { - Revela mudanças de padrões } \\
\text { (institucionais, sociais etc) no decorrer } \\
\text { do tempo } \\
\text { - Alguns dados podem ser de difícil } \\
\text { recuperação }\end{array}$ & $\begin{array}{l}\text { - Se realiza a partir da análise de documentos que } \\
\text { são referentes ao planejamento operacional e } \\
\text { estratégico do CBHRV. } \\
\text { - Foca-se na busca de relação entre termos e fatos } \\
\text { sociais pertinentes via análise de conteúdo }\end{array}$ \\
\hline Entrevista & $\begin{array}{l}\text { - Flexibilidade de aplicação } \\
\text { - Facilidade de adaptação de } \\
\text { protocolo } \\
\text { - Esclarecimento de respostas } \\
\text { - Pode ser aplicada a pessoas não } \\
\text { aptas a leitura } \\
\text { - Tem taxa de resposta elevada }\end{array}$ & $\begin{array}{l}\text { - Possui custo elevado de tempo e } \\
\text { operação } \\
\text { - Possível polarização do entrevistador } \\
\text { - Não garante o anonimato } \\
\text { - Pode interferir no comportamento do } \\
\text { entrevistado }\end{array}$ & $\begin{array}{l}\text { - Visa-se captar a percepção sobre os mesmos em } \\
\text { relação aos dados coletados em campo } \\
\text { (observação participante). } \\
\text { - Assim como na pesquisa documental, a busca de } \\
\text { sentido também ocorre pela análise de conteúdo. }\end{array}$ \\
\hline $\begin{array}{l}\text { Análise de } \\
\text { Conteúdo }\end{array}$ & $\begin{array}{l}\text { - Pode lidar com muitos dados } \\
\text { - Foca no que está presente } \\
\text { - Presta-se para dados históricos } \\
\text { - Utilização de dados brutos } \\
\text { - Estabelece tendências sociais e } \\
\text { com custo reduzido }\end{array}$ & $\begin{array}{l}\text { - Ao visar estabelecer frequências, se } \\
\text { descuida do que está ausente } \\
\text { - Pode perder a sequencialidade da } \\
\text { linguagem e do texto }\end{array}$ & $\begin{array}{l}\text { - A partir do roteiro de entrevista e dos itens } \\
\text { selecionados, são analisados os principais assuntos } \\
\text { listados pelos respondentes. }\end{array}$ \\
\hline
\end{tabular}

Programa de Pós-graduação em Saneamento, Meio Ambiente e Recursos Hídricos da UFMG 
As duas primeiras entrevistas foram consideradas enquanto "entrevistas-piloto" na relação das 26 entrevistas realizadas, para se testar se o formato da seleção de perguntas semiestruturadas estava de acordo com a intenção de identificar os limites e potencialidades da gestão dos recursos hídricos, assim como se conseguiriam criar espaços para as discussões pretendidas. Essa estratégia tem relação com as colocações, por exemplo, de Alami et al. (2010, p. 160), ao estabelecerem que

O roteiro de entrevista resta uma tela maleável, ele evolui conjuntamente com as entrevistas em função da efetiva pertinência de questões e da aparição de novas práticas que se queira descobrir. O roteiro de entrevistas propõe uma dinâmica, uma progressão nas temáticas por abordar, mas a ordem dessas questões não é imutável: o pesquisador se adapta à lógica da entrevista enquanto segue o itinerário das práticas evocadas.

As entrevistas foram projetadas para serem concluídas em até 60 minutos, o que acabou por ocorrer em 16 oportunidades (62\%). Foram feitas no formato semiestruturado pois, com roteiro feito e avaliado anteriormente à sua aplicação, com perguntas abertas e direcionadas para um público-alvo, as respostas puderam revelar as perspectivas das lideranças selecionadas.

Não foram feitas entrevistas consideradas "de profundidade", de longa extensão, mas sim entrevistas focadas nos temas selecionados e, como citado, com duração prevista em até 60 minutos de realização. Isso não impediu a repetição de perguntas, posteriormente, para checagem de material, um tipo de cuidado que YIN (2010) indica como forma de controle e verificação de respostas.

Da mesma forma, a técnica de indicação de entrevistados sequenciais conhecida como "amostragem por bola de neve" (ALAMI, DESJEUX, MOUSSAQUI, 2010; SANTOS, FILHO, 2011), não havia sido prevista para execução, mas acabou por ocorrer de forma parcial durante o processo de aplicação das entrevistas. Nessa técnica, utilizada com frequência para pesquisas com indivíduos de acesso mais restrito ou para populações de baixa incidências, é possível a realização de uma amostra linear de entrevista para estudos.

O que ocorreu na aplicação foi que a última pergunta do roteiro de entrevista era sobre indicação de possíveis lideranças a serem convidadas a participar do processo de entrevistas, e, nessa prática, vários dos nomes já haviam sido selecionados quando da constituição do rol 
de respondentes. Na verdade, o que ocorreu foi uma ação muito mais próxima do que YIN (2010, p. 203) denominada como "entrevista focada", ou seja,

(...) no qual a pessoa é entrevistada durante um curto período de tempo - uma hora, por exemplo. Nesses casos, as entrevistas até podem permanecer abertas e assumir uma maneira conversacional, mas é maior a probabilidade de ser seguido um determinado conjunto de questões derivadas do protocolo do estudo de caso.

Essa opção pelo formato semiestruturado permitiu um nível de flexibilidade constante nas entrevistas de forma a que todos os assuntos fossem abordados. Não foram identificados problemas na realização das mesmas, salvo apenas um único caso onde a gravação não foi permitida pelo entrevistado. Os locais de realização foram instituições públicas e privadas, escritórios particulares, residência e universidade, além de internet pelo uso de programa "Skype".

As entrevistas com as lideranças foram relativas aos seguintes segmentos:

Sociedade Civil (17): membros do CBHRV enquanto presidente e ex-presidentes; os membros da AGBPV em termos de diretoria; os membros do CBHRV enquanto representantes da sociedade civil; representantes de IES.

$>$ Poder Público Municipal (2): membros do comitê representantes da PBH e da Agência de Desenvolvimento Metropolitano de Belo Horizonte ADMBH.

Poder Público Estadual (4): membros do comitê representantes do IGAM e da Secretaria de Estado da Educação SEE.

Usuários (3): membros do comitê representantes da FIEMG e da COPASA.

Da mesma maneira, podem clarificar os impactos das ações dos subcomitês e do CBHRV em relação a ações efetivamente empregadas (esgotamento sanitário, melhora da qualidade/quantidade de água, mobilização social, drenagem urbana etc).

Também se pode assim identificar mensurar se o alcance do comitê se dá por suas ações internas administrativas/deliberativas ou por fatores externos à sua competência (política governamental regional e nacional, intervenções dos setores privados, financiamentos 
estruturais etc), fato que pode permitir uma compreensão maior também sobre a gestão ao nível de bacia hidrográfica.

Isto significa que mesmo sendo a unidade de planejamento considerada, a bacia hidrográfica em si representa apenas uma parte de todo o processo de tomada de decisões, que possui várias etapas e níveis institucionais para acontecer. Concomitantemente, o projeto visa identificar as políticas públicas em ação na bacia hidrográfica, como também aperfeiçoar as interpretações científicas e profissionais nelas contidas.

\subsection{Os "estudos de casos" como marco referencial para análises comparativas}

Foi escolhida a utilização metodológica de apreensão desta realidade através de um estudo de caso que demonstra ser capaz de fomentar generalizações de análise, sendo escolhido, enquanto elemento essencial no modelo de gestão institucional em vigor, um comitê de bacia hidrográfica de reconhecida inserção no cenário nacional (IGAM, 2015(b)), o denominado Comitê da Bacia Hidrográfica do Rio das Velhas.

O estudo de caso, deve-se salientar, possui características de, ao se estudar um caso em particular, verificar quais as suas variações em relação a um todo conceitual dado (LOWI, 1964), no caso a gestão das políticas públicas de recursos hídricos. Outra possibilidade do estudo de caso é uma estratégia de pesquisa onde a análise de dados fica direcionada, mas não condicionada (GIL, 2009; DEMO, 1985; SANTOS, FILHO, 2011), a um contexto de fenômenos mais detalhada e específico, o que pode favorece uma visão de panorama de uma dada situação de pesquisa:

A pesquisa qualitativa leva a sério o contexto e os casos para entender uma questão em estudo. Uma grande quantidade de pesquisa qualitativa se baseia em estudos de caso ou em séries desses estudos, e, com frequência, o caso (sua história e complexidade) é importante para entender o que está sendo estudado. (FLICK, 2009, p. 69).

Um ponto que é levantado por GIL (2009) e que interessa resgatar é que o estudo de caso não é pesquisa qualitativa por si só, preferindo utilizar o termo "estudo de caso qualitativo", pois outros elementos devem ser considerados:

Programa de Pós-graduação em Saneamento, Meio Ambiente e Recursos Hídricos da UFMG 
O estudo de caso não se pode ser confundido com pesquisa qualitativa. Embora a maioria dos estudos de caso adote uma abordagem qualitativa, podem ser identificados estudos de caso eminentemente quantitativos. Por outro lado, a maioria das pesquisas definidas como qualitativas não é constituída por estudos de caso. A confusão se dá porque muitos dos procedimentos adotados nos estudos de caso foram "tomados de empréstimo" das pesquisas qualitativas. Como exemplo, pode-se citar o conceito de amostragem teórica, definido pelos criadores da grounded theory, e a técnica da observação participante, procedimento básico da pesquisa etnográfica. (DENZIN e LINCOLN, 2006).

O que é identificado nessa perspectiva é que o estudo de caso é, em essência, um "delineamento de pesquisa" em que há uma investigação empírica de um dado fato social (o que também é discutido em SANTOS e FILHO (2011). Mais importante ainda, a questão é que o estudo de caso demanda a utilização de múltiplos procedimentos de coleta de dados, com a confrontação entre dados obtidos de formas distintas. Esse posicionamento está de acordo com o que foi efetuado na presente pesquisa, onde à análise de documentos foi adicionada a observações de campo e também as análises de entrevistas.

Há também o fato de que o estudo de caso favorece o entendimento do contexto em que ocorrem os fenômenos em estudo, o que é muito importante para compreender, no caso da análise da gestão de recursos hídricos, as interações institucionais existentes. Isso possibilita também que haja uma investigação "pelo lado de dentro" (GIL, 2009; YIN, 2010), a partir dos participantes dos eventos em estudo, o que, no caso de uma análise de organismos de bacia hidrográfica, pode ser considerado como de grande importância.

Essas escolhas dos instrumentos de fomento às análises se deram em razão da busca da pesquisa, em termos metodológicos, tentar responder também sobre as práticas encontradas no comitê de bacia hidrográfica referido. O pano de fundo para tanto é a identificação que se tem atualmente na mudança das abordagens tecnocêntricas de gerenciamento para abordagens mais integradas (GRANJA e WARNER, 2006), onde a organização institucional e a participação dos cidadãos são importantes para a consolidação de um sistema de gestão hídrico mais amplo, vinculados a processos políticos de tomada de decisões (TOTTI e AZEVEDO, 2013; TRAWICK, 2005).

Concomitantemente, o entendimento do alcance e das limitações da gestão participativa em cenários de tomada de decisões políticas e administrativas passa também pelo entendimento de casos particulares que possam gerar conclusões passíveis de serem comparativamente 
analisadas e generalizáveis minimamente (como visto também em HELLER, 2012), de modo a propiciar políticas públicas mais próximas das realidades que pretendem modificar, pois

Mesmo aquilo que podemos chamar de estudo de caso não pode ser entendido como a captação de meras particularidades. Pelo contrário, a cata de particularidades serve para gerar generalizações indevidas ou excessivamente abstratas. (...) Mesmo quando queremos explicar a variação dos fenômenos, o que fazemos praticamente é descobrir formas repetidas da variação. A saber, explicamos pela constância das diferenças, não pelas diferenças mesmas. (DEMO, 1985, p. 52).

E por isso mesmo que a conjugação de vários tipos de técnicas ${ }^{43}$ e em vários tipos de temas é proposto aqui como um rol de recorte metodológico de base qualitativa que delimite como a temática de pesquisa é trabalhada e com qual trajetória estrutural científica se estabelece frente a uma discussão tão complexa como é a da gestão de recursos hídricos no cenário atual (THEODORO, 2002 e 2014; ABERS, 2010).

O que se pode depreender da proposta é sobre o fato da pesquisa estar alicerçada em uma perspectiva metodológica de cunho qualitativo, apesar da apresentação de números e estatísticas inerentes ao planejamento e/ou implementação das políticas públicas, com a inclusão de técnicas de coleta e análise de dados, onde os meios físico, biótico e antrópico são subdivididos em 08 temáticas que, através de 18 perguntas estabelecidas nas 26 entrevistas semiestruturadas individuais com representantes dos 04 segmentos do CBHRV e do setor acadêmico, ajudam a compor as discussões institucionais, políticas e sociais da pesquisa.

\footnotetext{
${ }^{43}$ A escolha das práticas da pesquisa depende das perguntas que são feitas, e as perguntas dependem de seu contexto, do que está disponível no contexto e do que o pesquisador pode fazer naquele cenário. (DENZIN e LINCOLN, 2006, p. 153).
} 


\title{
5 ESTUDO DE CASO: O COMITÊ DA BACIA HIDROGRÁFICA DO RIO DAS VELHAS
}

\subsection{Caracterização geral da bacia}

Considerado como um Estado dotado tanto de localização estratégica (na Região Sudeste do País) como de recursos ambientais e hídricos, em grande disponibilidade, Minas Gerais se caracteriza como local onde quatro bacias hidrográficas nacionais estão inseridas: Paraná, Atlântico Leste, Atlântico Sudeste e São Francisco. Elas foram determinas de acordo com as determinações do Conselho Nacional de Recursos Hídricos (CNRH), via a Resolução $\mathrm{n}^{\circ} 32$, de 15 de outubro de 2003, que instituiu a Divisão Hidrográfica Nacional, como fundamento para a implantação do Plano Nacional de Recursos Hídricos. De acordo com IGAM (2007, pg 23):

\begin{abstract}
Segundo a Resolução, considera-se como região hidrográfica o espaço territorial brasileiro compreendido por uma bacia, grupo de bacias ou sub-bacias hidrográficas contíguas com características naturais, sociais e econômicas homogêneas ou similares, com vistas a orientar o planejamento e gerenciamento dos recursos hídricos.
\end{abstract}

De acordo com a Resolução n ${ }^{\circ}$ 32, o Estado de Minas Gerais abrange áreas de quatro Regiões Hidrográficas Nacionais (...).

1. Região Hidrográfica do São Francisco - RHSF (cobre $40 \%$ da área do Estado);

2. Região Hidrográfica do Paraná - RHPR (cobre 27\%);

3. Região Hidrográfica do Atlântico Leste - RHAL (cobre 17\%)

4. Região Hidrográfica do Atlântico Sudeste - RHAS (cobre 16\%)

O Estado de Minas Gerais possui um variado número de bacias hidrográficas (em torno de 10 mil cursos d'água, de acordo com IGAM $(2007 ; 2014)$ e que estão vinculadas com os critérios de classificação das instituições vinculadas ao tema. Por exemplo, a Companhia de Saneamento de Minas Gerais, assim como o Instituto Mineiro de Gestão das Águas (IGAM) adota o montante de 17 bacias hidrográficas mineiras (COPASA, 2014), advindas de dessas 4 regiões hidrográficas referidas (IGAM, 2007). Apesar de não haver nenhum definição clara e geral dos critérios adotados para a definição destas 17 bacias citadas (e demonstradas na Figura 5.1), o Relatório Técnico do Plano Estadual de Recursos Hídricos (em sua primeira 
etapa) indica ao menos duas prerrogativas. Uma é a questão consensual da demarcação e outra a questão das mesmas terem suas nascentes em Minas Gerais e transpondo os limites estaduais, a ver (IGAM, 2006, pgs 16-17):

(...) serão adotadas como unidades referenciais de estudo três divisões de recursos hídricos de consenso para o Estado de Minas Gerais:1. As 4 Regiões Hidrográficas Nacionais inseridas em Minas Gerais (...); 2. As 17 Bacias Hidrográficas existentes em Minas Gerais (...); 3. As 36 Unidades de Planejamento e Gerenciamento de Recursos Hídricos (UPGRHs), resultantes das subdivisões das 17 Bacias Hidrográficas.

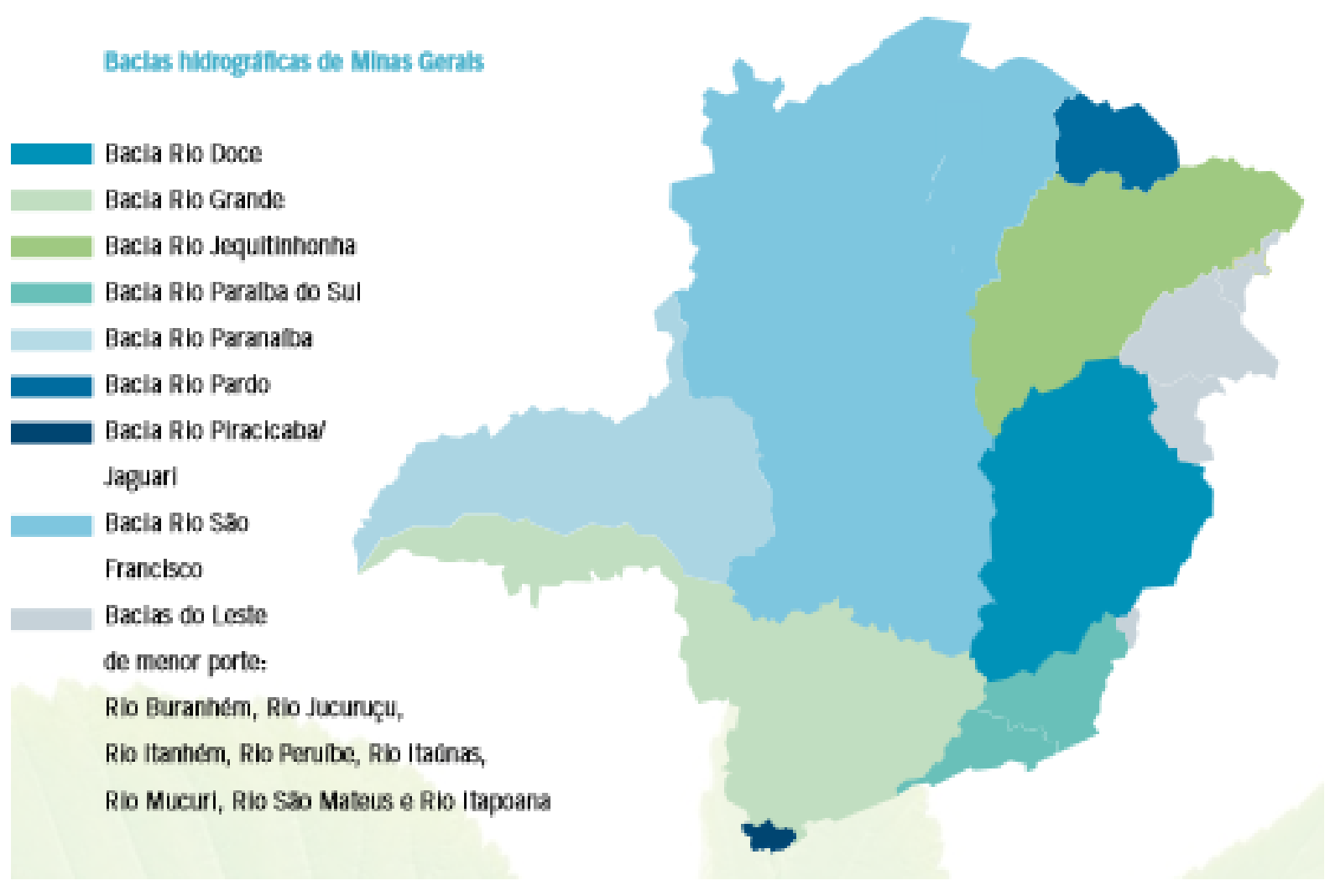

Figura 5.1: Bacias Hidrográficas de Minas Gerais

Fonte: COPASA (2014(a))

A bacia hidrográfica do Rio São Francisco, especificamente, além de ser considerada como um dos meios principais de integração hídrica do País, é a bacia hidrográfica onde se encontra o Rio das Velhas, objeto deste estudo.

A principal nascente do Rio das Velhas está localizada em Ouro Preto, na cachoeira das Andorinhas (1.500 metros de altitude), e o deságue acontece após 806,84 km de percurso, no referido Rio São Francisco, n município de Várzea da Palma, no distrito denominado de Barra

Programa de Pós-graduação em Saneamento, Meio Ambiente e Recursos Hídricos da UFMG 
do Guaicuí (478 metros de altitude), após percorrer os 51 municípios inseridos em sua bacia hidrográfica, sendo que 44 destes possuem suas sedes urbanas inseridas nos limites da bacia (CAMARGOS, 2005; CBHRV, 2015(a)):
1. Araçaí
2. Augusto de Lima
3.Baldim
4. Belo Horizonte
5. Buenópolis
6. Caeté
7. Capim Branco
8. Conceição do Mato
Dentro
9. Confins
10. Congonhas do Norte
11. Contagem
12. Cordisburgo
13. Corinto
14. Curvelo
15. Datas
16. Diamantina
17. Esmeraldas
18. Funilândia
19. Gouveia
20. Inimutaba
21. Itabirito
22. Jaboticatubas
23. Jequitibá
24. Joaquim Felício
25. Lagoa Santa
26. Lassance
27. Matozinhos
28. Monjolos
29. Morro da Garça
30. Nova Lima
31. Nova União
32. Ouro Preto
33. Paraopeba
34. Pedro Leopoldo
35. Pirapora
36. Presidente Juscelino
37. Presidente Kubitschek
38. Prudente de Morais
39. Raposos
40. Ribeirão das Neves
41. Rio Acima
42. Sabará
43. Santa Luzia
44. Santana de Pirapama
45. Santana do Riacho
46. Santo Hipólito
47. São José da Lapa
48. Sete Lagoas
49. Taquaraçu de Minas
50. Várzea da Palma
51. Vespasiano

Já o estado de Minas Gerais possui em seu território 36 Unidades de Planejamento e Gerenciamento de Recursos Hídricos (UPGRHs) que são resultantes das 17 bacias hidrográficas referidas, enquanto suas subdivisões (IGAM, 2014), e que está representada na Figura 5.2 adiante. O estado e Minas Gerais possui área de $586.528,29 \mathrm{~km}^{2}$, cerca de $7 \%$ da área total brasileira (IGAM, 2007; IGAM 2014) e 853 municípios, que perfazem 15,5\% do total de municípios do País.

É Minas Gerais o estado com maior número de cidades e também detém duas Regiões Metropolitanas: a de Belo Horizonte (RMBH), capital estadual, e a do Vale do Aço (RMVA), polo de desenvolvimento industrial do estado mineiro. No caso da RMBH importa colocar que mesmo com apenas $10 \%$ da área territorial da bacia, ela é responsável por deter $70 \%$ de sua população e com índices de desenvolvimento humano e institucional muito diferentes do que é encontrado no curso do Rio das Velhas. 


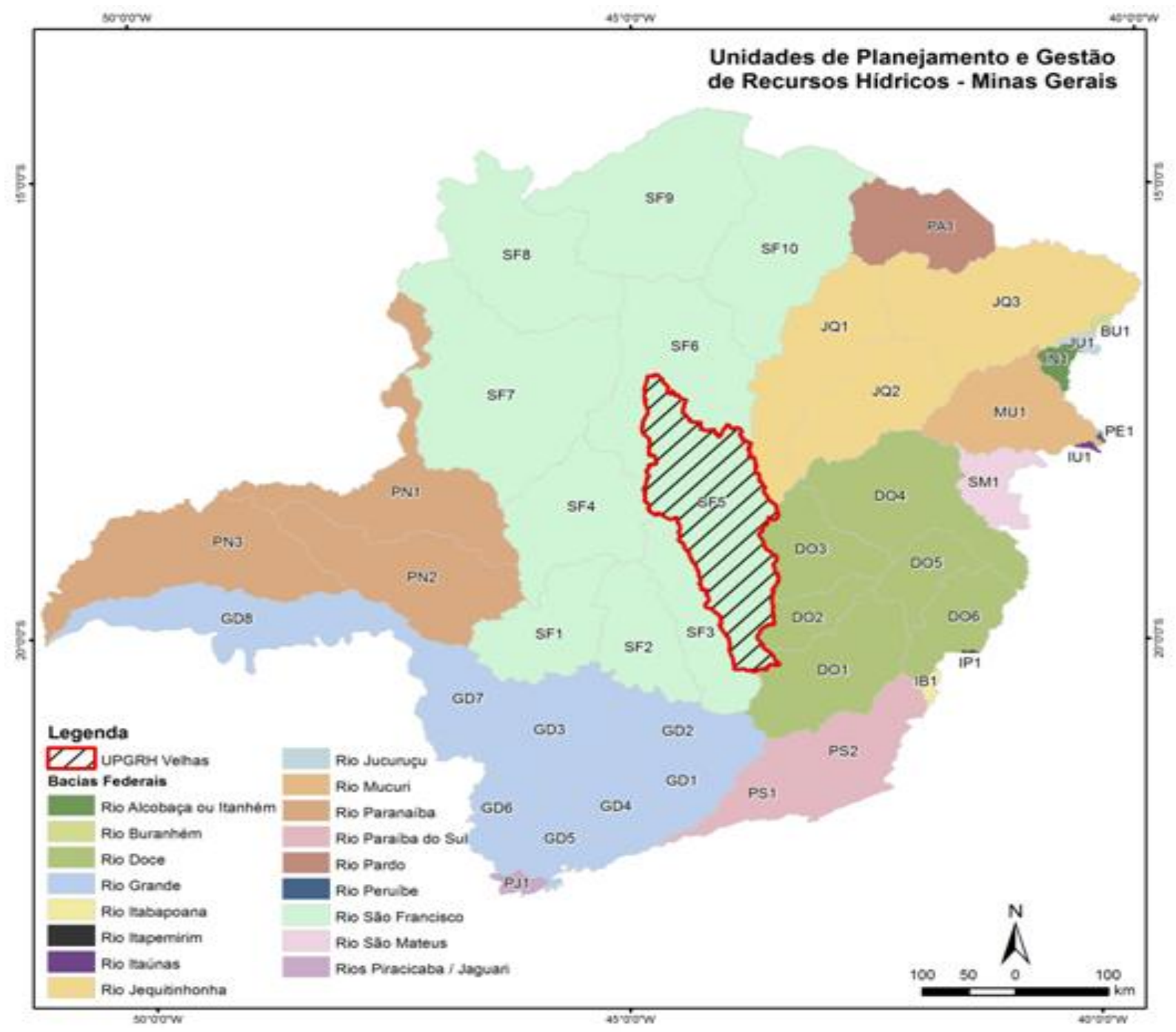

Figura 5.2: Unidades de Planejamento e Gestão de Recursos Hídricos (UPGRHs)

em Minas Gerais, 2010

Fonte: CBHRV (2015(a))

Tais informações demonstram o complexo contexto que envolve a gestão de recursos hídricos estadual, mas, ao mesmo tempo, a divisão do território em bacias para essa mesma gestão é pragmática, fazendo com que a realização e avaliação tanto do balanço hídrico como também dos impactos antrópicos seja facilitada. O fato também dela (RMBH) possui uma maior convergência de instituições ${ }^{44}$ relacionadas direta ou indiretamente com as questões sociais e ambientais favorece consequentemente uma maior massa crítica de análise do contexto da gestão hídrica.

\footnotetext{
${ }^{44} \mathrm{Na}$ realidade toda a base institucional do sistema de gestão ambiental estatual se situa praticamente na RMBH, com escritórios sucursais espalhados pelas outras regiões.
}

Programa de Pós-graduação em Saneamento, Meio Ambiente e Recursos Hídricos da UFMG 
É uma condição que potencializa uma articulação maior dos atores sociais e institucionais existentes, com vistas à construção de processos mais democráticos, compartilhados e de longo prazo.

Mais ainda, a capacidade administrativa e econômica dessa região para a criação de excedentes para possíveis investimentos incrementa a existência de programas de conservação, proteção ambiental, ainda mais quando é considerada a questão dos impactos urbanos e dos recursos hídricos. Conhecido como um dos campos temáticos de maior complexidade e diversidade conceitual e de aplicação, as políticas públicas para a gestão de recursos hídricos têm tido uma crescente demanda por seu aprofundamento analítico.

Esse movimento pode ser encarado como fruto das antigas e novas necessidades de entendimento sobre quais os mecanismos institucionais disponíveis para o melhoramento da gestão hídrica brasileira e mineira. Principalmente em local com perfil geográfico e demográfico tão próprio como o objeto de pesquisa aqui presente (Tabela 5.1), a bacia hidrográfica do Rio das Velhas e seu respectivo comitê.

Como pode ser identificado na tabela adiante, a bacia hidrográfica em estudo tem uma longa extensão (802 km2) que transpassa a região central de Minas Gerais, em um direcionamento Sul-Norte que perpassa em torno de $6 \%$ dos 853 municípios do estado. Uma especificidade dessa distribuição geográfica é que vários desses municípios contidos na bacia estão inseridos também na RMBH.

Com uma população crescente, principalmente em sua região metropolitana, a bacia referida tem também o maior número de outorgas para utilização de recursos hídricos, tanto em termos superficiais como também subterrâneos (que, inclusive, são em maior número). 
Tabela 5.1: Características gerais da bacia hidrográfica do Rio das Velhas

\section{Características Gerais da Bacia Hidrográfica do Rio das Velhas}

\begin{tabular}{ll}
\hline Área da bacia & $29.173 \mathrm{~km}^{2}$ \\
\hline Extensão do curso principal & $802 \mathrm{~km}$ \\
\hline Localização & Região Central de Minas Gerais \\
\cline { 2 - 2 } & Lat. $17^{\circ} 15^{\prime}-20^{\circ} 25^{\prime} \mathrm{S}$ \\
\cline { 2 - 2 } & Long. $43^{\circ} 251-44^{\circ} 50^{\prime} \mathrm{W}$ \\
\hline Ocupação & 51 municípios, sendo 14 contidos parcialmente \\
& na bacia e 15 na RMBH \\
\hline População (IBGE, 2010) & 4.858 .241 habitantes \\
\hline Outorgas superficiais vigentes & 717 outorgas $(2013)$ \\
\cline { 2 - 2 } & 852 outorgas $(2014)$ \\
\hline Outorgas subterrâneas vigentes & 694 outorgas $(2015)$ \\
\hline & 1.536 outorgas $(2013)$ \\
\cline { 2 - 2 } & 896 outorgas $(2014)$ \\
\hline
\end{tabular}

Fonte: Modificado e atualizado de IGAM (2011); IGAM (2014); IGAM (2014(e)).

Como principais sub-bacias referentes ao Comitê da Bacia Hidrográfica do Rio das Velhas (CBHRV), pode-se identificar: Arrudas (Belo Horizonte, Contagem, Sabará); Onça (Belo Horizonte, Contagem e Santa Luzia); Ribeirão da Mata (Capim Branco, Confins, Esmeraldas, Lagoa Santa, Matozinhos, Pedro Leopoldo, Ribeirão das Neves, Santa Luzia, São José da Lapa e Vespasiano); Itabirito (Itabirito); Sabará (Sabará); Rio do Peixe / Ribeirão Macacos / Córrego da Água Suja (Nova Lima); e Rio Jequitibá (Sete Lagoas e Jequitibá).

Tradicionalmente, a bacia hidrográfica em pesquisa foi subdividida em três grandes áreas de divisão administrativa, denominadas como "Alto Velhas" (onde está situada a Região Metropolitana de Belo Horizonte e a sua nascente); "Médio Velhas" (que está situada na região central do estado de Minas Minas) e o "Baixo Velhas" (onde está localizada a confluência entre o Rio das Velhas e o Rio São Francisco) - essa divisão está colocada na Figura 5.3. 


\section{BACIA DO RIO DAS VELHAS}

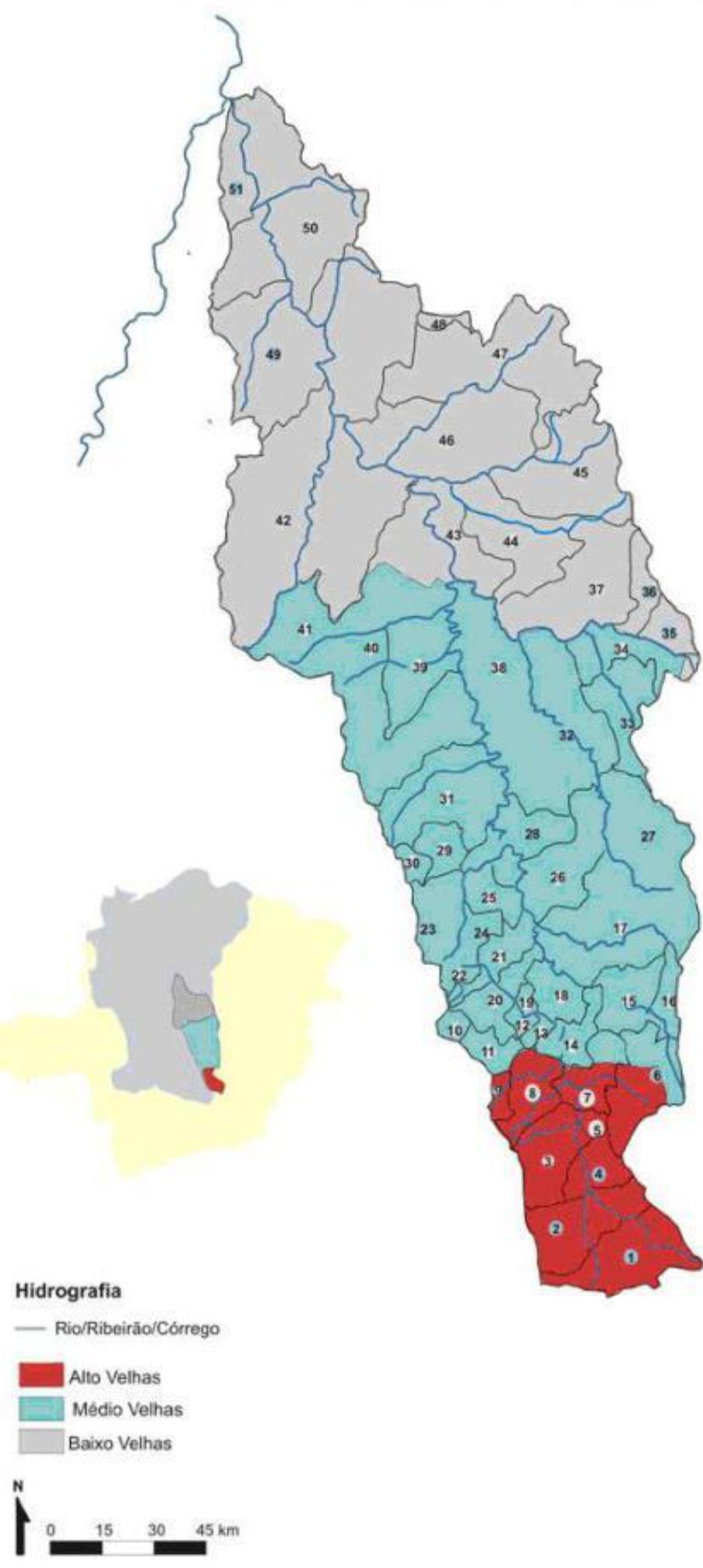

\section{Municipios}

1. Ouro Preto

2. Itabirito

3. Nova Lima

4. Rio Acima

5. Raposos

6. Caeté

7. Sabará

8. Belo Horizonte

9. Contagem

10. Esmeraldas

11. Ribeirão das Neves

12. São José da Lapa

13. Vespasiano

14. Santa Luzia

15. Taquaraçu de Minas

16. Nova União

17. Jabuticatubas

18. Lagoa Santa

19. Cofins

20. Pedro Leopoldo

21. Matozinhos

22. Capim Branco

24. Prudente de Morais

25. Funilândia

26. Baldim

27. Santana do Riacho

28. Jequitibá

29. Araçai

30. Paraopeba

31. Cordisburgo

32. Santana de Pirapama

33. Congonhas do Norte

34. Conceiçăo do Mato Dentro

35. Presidente Kubtechek

36. Datas

37. Gouveia

38. Presidente Juscelino

39. Inimutaba

40. Curvelo

41. Morro da Garça

42. Corinto

43. Santo Hipólito

44. Monjolos

45. Diamantina

46. Augusto de Lima

47. Buenópolis

48. Joaquim Felício

49. Lassance

50. Várzea da Palma

51. Pirapora

Projeçāo Universal de Mercartor Mericiano Central de $45^{\circ}$ W Datum SAD69 Fonte: IGAM

Figura 5.3: Divisão administrativa da bacia hidrográfica do Rio das Velhas (1998-2014) Fonte: PROJETO MANUELZÃO (2015) 
Com a atualização do Plano Diretor de Recursos Hídricos (PDRH), ocorrido em 2015, a bacia hidrográfica em estudo foi subdividida em 23 diferentes regiões de planejamento com vistas à otimização de sua gestão sob o viés democrático e participativo. Isso ocorreria, em tese, com o aumento das interações entre os atores sociais locais que estariam mais convergidos em atuação coletiva na medida em que estariam a atuar em suas áreas próximas. Mais ainda, em uma segunda instância, essa subdivisão favoreceria no longo prazo que a consolidação de um planejamento do comitê vias as necessidades demonstradas pelas próprias populações ribeirinhas.

Elas foram denominadas de Unidades Territoriais Estratégicas (UTEs) - demonstrada na Figura 5.4, definidas em legislação própria do comitê, via a Deliberação Normativa $\mathrm{n}^{\circ} 01$, de 09 de fevereiro de 2012, que considera em sua constituição os princípios estabelecidos tanto na Lei Federal no 9.433, Lei Estadual n $13.199 / 99$ (que prevê a descentralização da gestão hídrica e com a participação de usuários, comunidades e poder público) e na Deliberação Normativa CBH Rio das Velhas nº $02 / 2004$ (alterada pela Deliberação Normativa 01/2009) que prevê diretamente a necessidade de:

1) estabelecer Unidades Territoriais Estratégicas (UTE) para auxiliar o planejamento e gestão da bacia do Rio das Velhas;

2) orientar a delimitação territorial dos Subcomitês, vinculados ao CBH Rio das Velhas;

3) incorporar ao Plano Diretor de Recursos Hídricos da bacia Hidrográfica do Rio das Velhas diretrizes que propiciem a descentralização das ações e do planejamento;

4) qualificar a elaboração de programas de desenvolvimento e outros estudos regionais para os contextos geográficos diversificados da bacia do Rio das Velhas;

5) subsidiar a aplicação descentralizada dos recursos da cobrança pelo uso de recursos hídricos na bacia Hidrográfica do Rio das Velhas;

6) ampliar a participação de atores locais nas ações de planejamento e gestão de recursos hídricos na bacia do Rio das Velhas. 


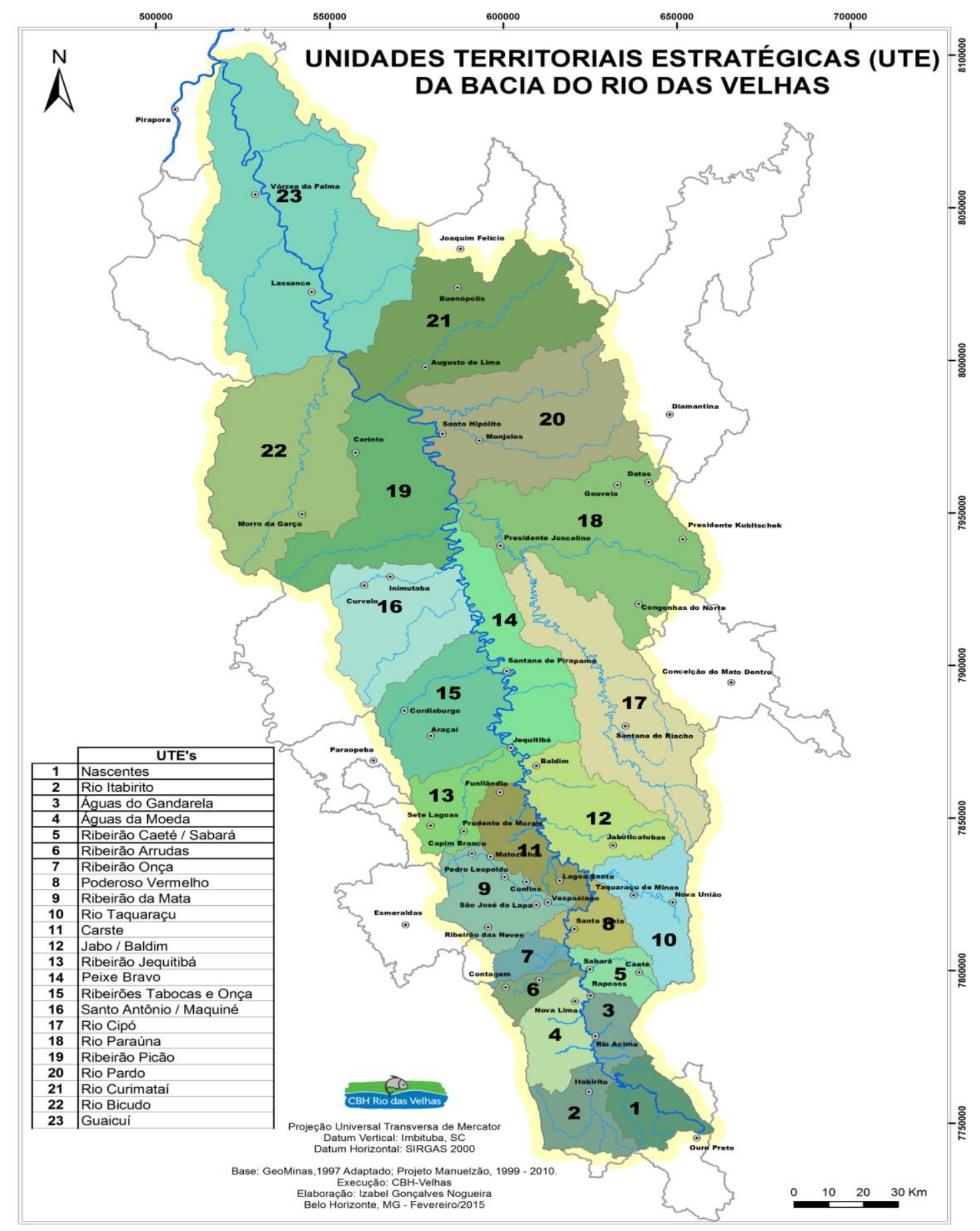

Figura 5.4: Unidades Territoriais Estratégicas da bacia hidrográfica do Rio das Velhas (2015)

Fonte: CBHRV (2016)

Também é considerada, na perspectiva do PDRH, a subdivisão macro da bacia em 04 grandes áreas, denominadas de "Baixo Rio das Velhas" (08 municípios); "Médio-Baixo Rio das Velhas" (23 municípios); "Médio Rio das Velhas" (20 municípios) e "Alto Rio das Velhas" 
(10 municípios) - como é visto na Figura 5.5. Já na perspectiva dos membros do comitê que foram pesquisados e da população da bacia em geral, normalmente utiliza-se somente as denominações de Alto ou Médio ou Baixo Rio das Velhas para a referência à alguma área em particular, dada a concepção histórica desta subdivisão.

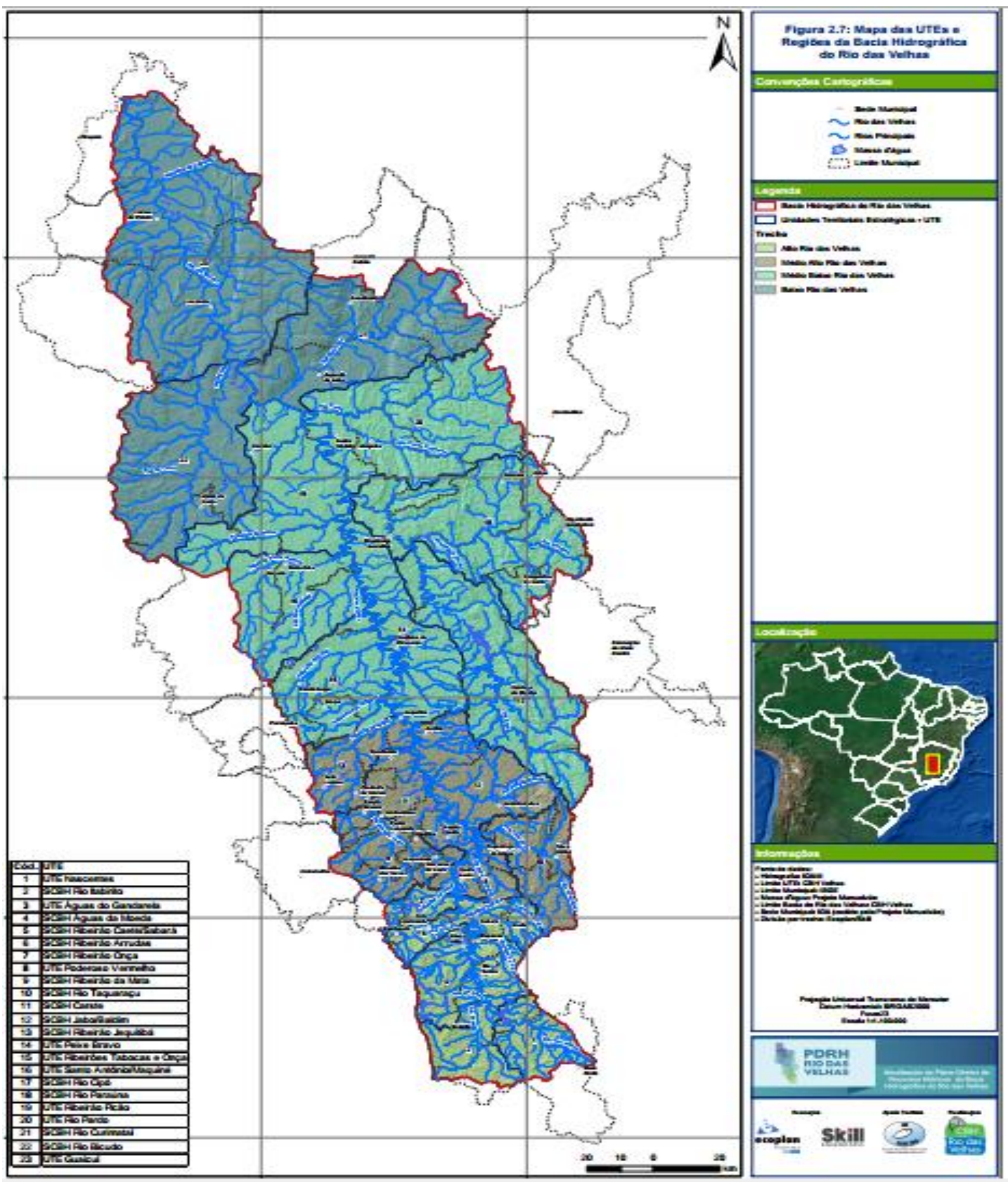

Figura 5.5: Segmentação administrativa da bacia hidrográfica do Rio das Velhas (2015) Fonte: CBHRV (2016)

Programa de Pós-graduação em Saneamento, Meio Ambiente e Recursos Hídricos da UFMG 
Essa ampliação de áreas no plano ocorreu para ajustar, por características de semelhanças em termos de ocupação e uso do solo, hidrografia, relevo, e presença da RMBH. Consequentemente, a histórica região denominada de "Médio Rio das Velhas" foi subdividida devido sua diversidade, o que gerou o Quadro 5.1:

Quadro 5.1: Relação entre as UTEs e as regiões da bacia hidrográfica do Rio das Velhas a partir do Plano Diretor de Recursos Hídricos, revisado e publicado em 2015.

\begin{tabular}{|c|c|c|c|c|}
\hline Região & & UTE/SCBH & Área $\left(\mathrm{km}^{2}\right)$ & Percentual da bacia \\
\hline \multirow{7}{*}{ Alto } & 1 & UTE Nascentes & 541,58 & $1,94 \%$ \\
\hline & 2 & SCBH Rio Itabirito & 548,89 & $1,97 \%$ \\
\hline & 3 & UTE Águas do Gandarela & 323,66 & $1,16 \%$ \\
\hline & 4 & SCBH Águas da Moeda & 544,32 & $1,95 \%$ \\
\hline & 5 & SCBH Ribeirão Caeté/Sabará & 331,56 & $1,19 \%$ \\
\hline & 6 & SCBH Ribeirão Arrudas & 228,37 & $0,82 \%$ \\
\hline & 7 & SCBH Ribeirão Onça & 221,38 & $0,79 \%$ \\
\hline \multirow{6}{*}{ Médio Alto } & 8 & UTE Poderoso Vermelho & 360,48 & $1,29 \%$ \\
\hline & 9 & SCBH Ribeirão da Mata & 786,84 & $2,83 \%$ \\
\hline & 10 & SCBH Rio Taquaraçu & 795,50 & $2,86 \%$ \\
\hline & 11 & SCBH Carste & 627,02 & $2,25 \%$ \\
\hline & 12 & SCBH Jabo/Baldim & $1.082,10$ & $3,89 \%$ \\
\hline & 13 & SCBH Ribeirão Jequitibá & 624,08 & $2,24 \%$ \\
\hline \multirow{7}{*}{ Médio Baixo } & 14 & UTE Peixe Bravo & $1.169,89$ & $4,20 \%$ \\
\hline & 15 & UTE Ribeirões Tabocas e Onça & $1.223,26$ & $4,39 \%$ \\
\hline & 16 & UTE Santo Antônio/Maquiné & $1.336,82$ & $4,80 \%$ \\
\hline & 17 & SCBH Rio Cipó & $2.184,86$ & $7,85 \%$ \\
\hline & 18 & SCBH Rio Paraúna & $2.337,61$ & $8,39 \%$ \\
\hline & 19 & UTE Ribeirão Picão & $1.716,59$ & $6,16 \%$ \\
\hline & 20 & UTE Rio Pardo & $2.235,13$ & $8,03 \%$ \\
\hline \multirow{3}{*}{ Baixo } & 21 & SCBH Rio Curimataí & $2.218,66$ & $7,97 \%$ \\
\hline & 22 & SCBH Rio Bicudo & $2.274,48$ & $8,17 \%$ \\
\hline & 23 & UTE Guaicuí & $4.136,93$ & $14,85 \%$ \\
\hline Bacia do rio das Velha & & & $27.850,00$ & \\
\hline
\end{tabular}

Fonte: CBHRV (2015(a))

A DN 01/12, assim como todo o arcabouço normativo-legal já referido, tem como pretensão então a consolidação de um modelo de gestão descentralizado e participativo com a manutenção das características regionais presentes na bacia. É um desafio de longo prazo para a gestão hídrica da mesma na medida em que as delimitações geográficas, físicas e políticas são inerentemente distintas e com dinâmicas diferentes. No entanto, o modelo anterior de determinação por macrorregiões se mostrou insuficiente para dar conta de um planejamento de maior inserção das populações locais, anteriormente muito desmobilizadas, principalmente na porção norte da bacia.

Programa de Pós-graduação em Saneamento, Meio Ambiente e Recursos Hídricos da UFMG 
Apesar do novo desenho territorial proposto, ainda se mostram recentes as ações ou resultados de tal medida, como, por exemplos, o aumento de reuniões e/ou eventos regionais relacionados com a gestão da bacia, a inclusão de mais temas vinculados com a gestão ao nível local nas reuniões ordinárias do comitê e, finalmente, com a distribuição e aplicação dos recursos advindos da cobrança pelos usos múltiplos considerando a distribuição espacial via UTEs. Na mesma direção, tanto nas entrevistas com lideranças vinculadas direta ou indiretamente ao CBHRV, quanto na pesquisa de campo, a gestão por UTEs demonstrou estar em consolidação nas práticas do comitê, porém com perspectivas de serem gradativamente incorporadas nos planejamentos institucionais do mesmo. Sua efetivação como instrumento de gestão hídrica, assim, depende da recorrência de processos de tomada de decisão realmente democráticos e participativos ancorados nas determinações legais.

\subsection{Histórico da bacia hidrográfica do Rio das Velhas}

A análise sobre a dinâmica atual da bacia hidrográfica do Rio das Velhas e de seu comitê só alcança sentido quando se faz uma recuperação de suas origens, de sua formação sócio histórica e narrativas individuais/coletivas que podem ser perdidas frente aos seus desafios de gestão atuais ${ }^{45}$. Esta busca por seus dados anteriores faz, todavia, ao invés de tornar esta pesquisa apenas descritiva, evoca um inerente trabalho de (re)descoberta de toda uma região central em Minas Gerais, que foi intensamente explorada desde seus primórdios (CBHRV, 2015). Fosse por seu imenso potencial de agropecuária e urbanização (devido sua localização estratégica no território), fosse por seu grande veio mineral de ouro e pedras preciosas, principalmente (CAMARGOS, 2005; BURTON, 1977; GOULART, 2005; ABERS, 2002).

Certamente que tal ocupação intensa teve e tem vinculação direta com os recursos naturais e hídricos da região, desde o início do século XVIII (BURTON, 1977) até os dias de hoje, ainda mais na região denominada ainda de "Alto Rio das Velhas", onde estão as cidades mais desenvolvidas e com maiores populações. É um tipo de ocupação do espaço bem próprio dos adensamentos humanos junto ao meio ambiente próximo das primeiras localidades, como salienta Denhez (2013, p. 23): “A maior parte das grandes cidades são implantadas na borda

\footnotetext{
45 "A avaliação de programas é um dos principais terrenos da pesquisa qualitativa, e os pesquisadores qualitativos podem influenciar as políticas sociais em importantes aspectos." (DENZIN e LINCOLN, p. 160).
}

Programa de Pós-graduação em Saneamento, Meio Ambiente e Recursos Hídricos da UFMG 
de um rio: ele é, com efeito, um meio de transporte fácil e de baixo cusot que possui a vantagem de dirigir ao mar.". E a busca por metais preciosos em municípios como Santa Luzia, Ouro Preto, Sabará, Caeté e Raposos (próximas à localização atual da capital Belo Horizonte), fez com que que tal área fosse primeiramente a sofre ações antrópicas e também ajudou a definir o próprio nome do estado:

(...) o nome Minas Gerais passou a ser citado a partir de 1720, quando aparece em alguns documentos, e oficialmente apenas a partir de $1730 \mathrm{em}$ diante, quando passa a ser empregado nas Cartas Régias. (...) Passou a ter maior importância para os portugueses somente em torno do ano de 1700, com a descoberta do ouro. (GOULART, 2005, p. 24).

O território do Rio das Velhas retrata bem a posição dos recursos da região serem considerados apenas como bens de suporte ao desenvolvimento da coroa portuguesa no país, sem consideração ao imenso potencial de integração regional, que foi pouco utilizado até o início do século XX. O que demonstra como foi presente uma dificuldade de vinculação entre desenvolvimento demográfico, social e preservação ambiental na região (FURTADO, 2009; CBHRV, 2013(b); CARNEIRO, ASSIS, 2012; RIBEIRO, 2005).

\subsubsection{O Projeto Manuelzão}

Seria difícil e incompleta a tentativa de compreender as formas de gerenciamento da bacia hidrográfica do Rio das Velhas sem se remeter, direta ou indiretamente ao principal ator político da região: o Projeto Manuelzão. Isto porquê é bem estabelecida a força e influência deste movimento social dentro da dinâmica de criação, organização e mobilização dos agentes institucionais do Rio das Velhas, e o entendimento de sua formação e formas de atuação são, assim, inerentes ao estudo. Entretanto, é importante ressaltar que apesar de seu destaque na gestão hídrica regional, o Projeto Manuelzão não foi quem criou o modelo de gestão do CBHRV, que advém de determinações jurídicas, institucionais e políticas estaduais e federais das quais ele faz parte.

O primeiro texto do Projeto Manuelzão (também citado por LISBOA (2012) como PMz) foi impresso em novembro de 1990 (com o nome de "Projeto Rio das Velhas"), sendo revisto em 1996. A proposta do projeto, segundo alega o grupo formador, é de não ser simplesmente um produto do campo acadêmico e sim fazer deste um veículo de transformação social, e de maior alcance do que era conseguido no internato rural via UFMG - até porque, segundo o $\mathrm{PMz}$, confunde-se saúde (sua promoção) com meramente assistência médica, tanto na área da 
própria Medicina como na sociedade em geral. Na Figura 5.6 é demonstrada a primeira equipe do Projeto Manuelzão, com viés oriundo do campo médico, porém com tendência para a formação multidisciplinar.

A primeira pergunta que nos salta à mente é tentar responder porque um projeto com um nome próprio o que o mesmo significa e, no caso aqui presente, o mesmo se justifica na medida em que simboliza uma personagem realmente bastante conhecida no cenário principalmente literário mineiro e até nacional. Este reconhecimento se dá porque "Manuelzão" em realidade nos remete ao papel desempenhado em um livro de João Guimarães Rosa (mineiro de Cordisburgo) do vaqueiro Manuel Nardi (mineiro da cidade de Dom Silvério). Este, com sua postura calma e ao mesmo tempo decidida teve bom um relacionamento com o referido escritor, que decidiu lhe dedicar páginas de suas estórias (a partir do encontro dos dois em $1952^{46}$ ) ao sertanejo que bem caracterizou o espaço dos interiores das gerais.

Assim, vale enfatizar que este projeto tem como foco a revitalização do Rio das Velhas enquanto uma bacia hidrográfica de qualidade, e sua existência remete ao ano de 1997, quando, através de uma iniciativa originalmente nascida de atividades de alguns professores do internato rural $^{47}$ da Universidade Federal de Minas Gerais (UFMG), percebeu-se a vinculação entre a o meio ambiente da região do rio e as condições sociais de existência das populações locais.

46 A viagem empreendida pelos dois, de quase duas semanas, renderia os seguintes livros ao artista: "Corpo de Baile", "Manuelzão e Miguilim", "No Urubuquaquá, no Pinhém”, "Noites do Sertão" e o seu mais famoso intento, o "Grande Sertão Veredas" (considerado uma inovação literária tanto na narrativa quanto no uso de construção gramaticais originais.

47 Denominado de "Internato em Saúde Coletiva" que, na verdade, era uma disciplina do curso de Medicina da UFMG, com duração de três meses de aplicação, com existência desde o ano de 1978.

Programa de Pós-graduação em Saneamento, Meio Ambiente e Recursos Hídricos da UFMG 


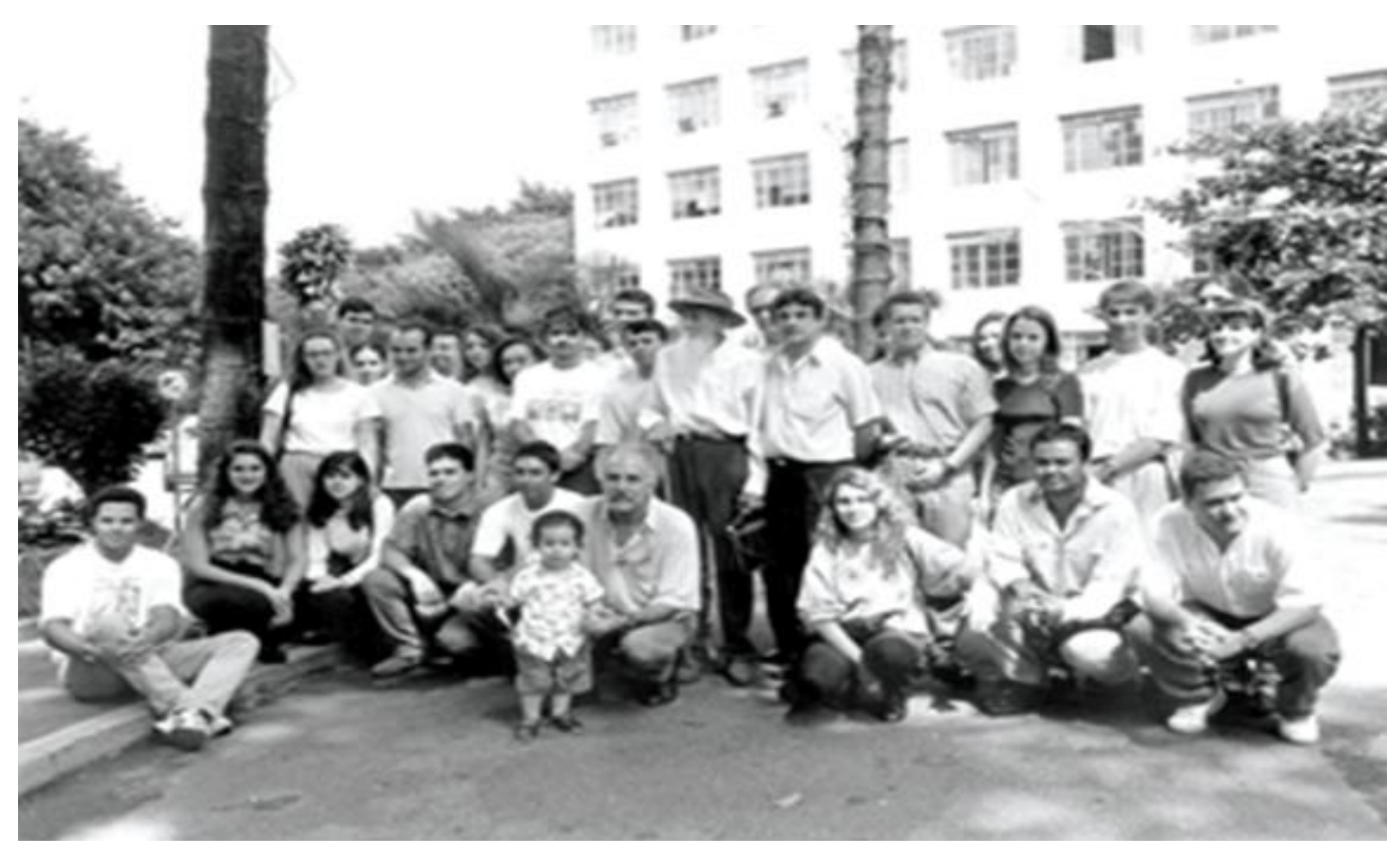

Figura 5.6: Primeira equipe do "Projeto Manuelzão", com a participação do próprio, no centro da fotografia; o idealizador, sr. Apolo Henringer Lisboa, se encontra agachado ao mesmo.

Fonte: LISBOA (2012)

A questão sobre a água surgiu, na realidade, através de discussões e levantamentos sobre condições do lixo, das doenças infectocontagiosas e dos esgotos das regiões assistidas pelo internato, tornando-se clara a necessidade de se superar o pensamento disciplinar e setorial para tratar de temas como qualidade de vida e saúde pública.

Esta observação acabou por dar fôlego ao início de uma busca de organização da sociedade do entorno do Rio das Velhas na direção da recuperação efetiva da qualidade e quantidade (sempre trabalhando estes dois índices em conjunto) deste trecho de rio que, tal como se sabe, alcança 51 municípios. E em todo este conjunto de cidades distribuídas pelos mais de $700 \mathrm{~km}$ de extensão da bacia hidrográfica o Projeto Manuelzão tenta implementar seus representantes,

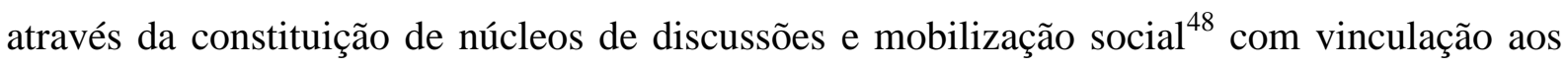
representantes locais - o que a organização denomina como "pertencimento de bacia". Ou como salienta Lisboa (2012):

48 São os chamados "Núcleos Manuelzão" que estão espalhados pela bacia como suporte ao próprio
projeto.

Programa de Pós-graduação em Saneamento, Meio Ambiente e Recursos Hídricos da UFMG 
A bacia hidrográfica questiona a hegemonia do municipalismo (...). As águas de uma bacia, unindo todas as pessoas desse território, se tornando o eixo geográfico de uma proposta necessitava de indicadores de qualidade e o $\mathrm{PMz}$ foi além dos monitoramentos físicos e químicos convencionais das águas, trazendo a proposta da volta do peixe, que impulsiona, ele próprio, por sua lógica dedutível por quase todos, uma série de ações.

O objetivo era desde o início conseguir sensibilizar as populações ribeirinhas da importância de posturas mais ativas para que a preservação do rio pudesse ocorrer, dadas as evidências registradas durante os estágios de internato de que os bens hídricos tinham influência na qualidade de vida destas mesmas populações.

Obviamente que o status que conseguiu atualmente não foi fruto apenas de ações individualizadas, visto a amplitude que as propostas foram sendo trabalhadas e, neste caminho, o Projeto Manuelzão, ao firmar parcerias com o governo de Minas Gerais, assim como com empresas de saneamento e outros atores, passou a agir como uma OSCIP (Organização da Sociedade Civil de Interesse Público) denominada de "Instituto Guaicuy" e que foi reconhecida pelo Ministério Público no ano de 2002 (2 anos após sua fundação).

Cabe aqui destacar que o Instituto Guaicuy recebe este nome não por acaso, e sim por sua vinculação estreita com o nome que as tribos indígenas que margeavam (o ainda não batizado, na época) Rio das Velhas de "Uauimii", ou Guaicuí que, em termos gerais, significa o "Rio das Velhas Descendentes" (GOULART, 2005) ${ }^{49}$.

Este ente jurídico foi fundado no ano 2000 para suporte ao Projeto Manuelzão, sendo considerada como uma Organização da Sociedade Civil de Interesse Público (OSCIP). Esta denominação legal, baseada na Lei Federal n 9.790, de 23 de Março de 1999, em seu Art. $1^{\circ}$ é assim qualificada:

Art. $1^{\circ}$ Podem qualificar-se como Organizações da Sociedade Civil de Interesse Público as pessoas jurídicas de direito privado sem fins lucrativos que tenham sido constituídas e se encontrem em funcionamento regular há, no mínimo, 3 (três) anos, desde que os respectivos objetivos sociais e normas estatutárias atendam aos requisitos instituídos por esta Lei.

\footnotetext{
49 A explicação pode ser encontrada no fato de que, culturalmente, os bandeirantes, ao conhecerem o rio, acabaram por lhe imputar tal nome ao notarem o grande número de anciãs nos leitos, remanescentes únicas do êxodo dos jovens que estavam receosos das investidas dos invasores brancos. Entretanto, haveria uma outra hipótese de nome, a partir do que relata CAMARGOS (2005:24), de que "O nome rio das Velhas foi provavelmente atribuído pelo Governador Antônio de Albuquerque Coelho de Carvalho no ano de 1.711. O rio apresentava a primitiva denominação indígena de UAIMII, alterada para GUAICHUI, que significa "Rio das Velhas Tribos Descendentes"." - vê-se porém que as duas vertentes são semelhantes e não necessariamente conflitivas.
}

Programa de Pós-graduação em Saneamento, Meio Ambiente e Recursos Hídricos da UFMG 
Pelo escrito, o perfil exigido estava adequado para a inclusão do novo Instituto Guaicuy como representação jurídica do Projeto Manuelzão. Inclusive a cumprir as exigências contidas no Art. $4^{\circ}$, com destaque para o Inciso II, que destaca que:

(...)II - a adoção de práticas de gestão administrativa, necessárias e suficientes a coibir a obtenção, de forma individual ou coletiva, de benefícios ou vantagens pessoais, em decorrência da participação no respectivo processo decisório.

Destaca-se, porém, que apenas essa assimilação da questão jurídica para a tomada de decisão e de representação do Projeto Manuelzão não garantiu a exclusão de conflitos entre os interesses dessa organização junto a outros membros do CBHRV. Mas, por outro, essa entidade legal que é a OSCIP, permite atuar, ao menos teoricamente, sem a conotação político-partidária da organização que assim agir, e com amplo acesso aos seus registros:

Art. 16. É vedada às entidades qualificadas como Organizações da Sociedade Civil de Interesse Público a participação em campanhas de interesse político-partidário ou eleitorais, sob quaisquer meios ou formas.

Art. 17. O Ministério da Justiça permitirá, mediante requerimento dos interessados, livre acesso público a todas as informações pertinentes às Organizações da Sociedade Civil de Interesse Público.

Certo que garantiu uma segurança jurídica mais consistente para a organização que já existia há 3 anos com atuações na temática socioambiental. Por outro lado, a presidência do comitê referido continua com o Instituto Guaicuy/Projeto Manuelzão, desde o ano de 2003, que conseguiu, via negociação com os pares, eleger 3 presidentes para 5 mandatos - Apolo Heringer Lisboa, Rogério Sepúlveda e Marcus Vinícius Polignano - Quadro 5.2.

O que é percebido é que ao agir com esta constituição jurídica o trabalho da organização foi melhorado e permitiu avanços de parceria, sendo uma das principais a que foi desenvolvida junto à FUNDEP (Fundação de Desenvolvimento da Pesquisa). Esta instituição é a responsável pela realização da gestão de projetos de ensino, pesquisa e extensão da UFMG.

A notar que o indicativo socioambiental sob o qual o Projeto Manuelzão se estabelece é no da recuperação da qualidade do rio através da volta do peixe à bacia, o que, segundo coloca a organização, refletiria que operacionalmente as ações desempenhadas pelo projeto estariam surtindo o efeito de modificação da realidade do bem hídrico na região, incluindo-se aí a gestão por bacia (mais do que simplesmente a gestão por municípios, o que sempre complexo

Programa de Pós-graduação em Saneamento, Meio Ambiente e Recursos Hídricos da UFMG 
de se acontecer por ser a água um objeto de estudo que supera os limites geográficos tradicionais).

Quadro 5.2: Histórico das principais atividades vinculadas ao Rio da Velhas e Projeto Manuelzão

\begin{tabular}{|l|l|}
\hline ANO & \multicolumn{1}{|c|}{ ATIVIDADE } \\
\hline 1867 & Descrição etnográfica, biológica e características gerais do Rio das Velhas \\
\hline 1952 & Encontro entre João Guimarães Rosa e Manuel Nardi ("Manuelzão") \\
\hline 1978 & Internato em Saúde Coletiva da UFMG \\
\hline 1990 & Primeiro texto do Projeto Manuelzão \\
\hline 1996 & Revisão do primeiro texto do Projeto Manuelzão \\
\hline 1997 & Fundação do Projeto Manuelzão \\
\hline 1997 & "Plano de Recursos Hídricos da Bacia do Rio das Velhas" - documento preliminar \\
& que serviu de base para a o PDRH \\
\hline 1998 & Indicação de João Israel Neiva para presidente do CBHRV \\
\hline 1998 & Criação da Unidade Técnica Executiva Interinstitucional (UT) \\
\hline 1999 & Lei Estadual dos Recursos Hídricos - n' 13.199/99 \\
\hline 2000 & Fundação do Instituto Guaicuy \\
\hline 2000 & Eleição de Paulo Maciel Jr. - Secretaria Municipal de Meio Ambiente \\
\hline 2002 & Reconhecimento do Instituto Guaicuy pelo Ministério Público \\
\hline 2003 & $\begin{array}{l}\text { Lançamento do documento "Características gerais do Rio das Velhas" - } \\
\text { documento preliminar ao lançamento do PDRH }\end{array}$ \\
\hline 2003 & Eleição de Apolo Heringer Lisboa - Instituto Guaicuy \\
\hline 2004 & Lançamento do Plano Diretor de Recursos Hídricos do Rio das Velhas (PDRHRV) \\
\hline 2004 & Deliberação Normativa CBH Velhas no 02 (Diretrizes de atuação dos subcomitês) \\
\hline 2004 & Declaração de Princípios do Comitê da Bacia Hidrográfica do Rio das Velhas \\
\hline 2005 & Reeleição de Apolo Heringer Lisboa - Instituto Guaicuy \\
\hline 2008 & Eleição de Rogério Sepúlveda - Instituto Guaicuy \\
\hline 2010 & Reeleição de Rogério Sepúlveda - Instituto Guaicuy \\
\hline 2013 & Eleição de Marcus Vinícius Polignano - Instituto Guaicuy \\
\hline 2015 & Atualização do Plano Diretor (início) \\
\hline
\end{tabular}

Fonte: Adaptado de THEODORO (2002), CAMARGOS (2005), LISBOA (2012), COSTA (2008), CBHRV (2015(a))

\subsubsection{Organização do Projeto Manuelzão}

Dada a organização interna do Projeto Manuelzão, fica claro que esta organização tenta imprimir um razoável grau de profissionalização de seus quadros para a atuação frente aos eventos do Rio das Velhas, inclusive com assentos em várias instâncias de consulta e decisão, com destaque natural ao Comitê da Bacia Hidrográfica do Rio das Velhas.

O fato também de que possui, por um lado, uma infraestrutura de trabalho em parceria com o governo estadual e, por outro, detém dados de pesquisa que são avaliados em suas rotinas 
pode um quadro atualizado de participantes (voluntários ou não ${ }^{50}$ ) pode tornar real a constatação de que o Projeto Manuelzão consegue imprimir maior nível de articulação e mobilização do que outros atores sociais envoltos na gestão da bacia descrita. Inclusive pela evidência (Figura 5.7) de que possui uma organização para ações distintas, de acordo com a temática a ser trabalhada ${ }^{51}$.

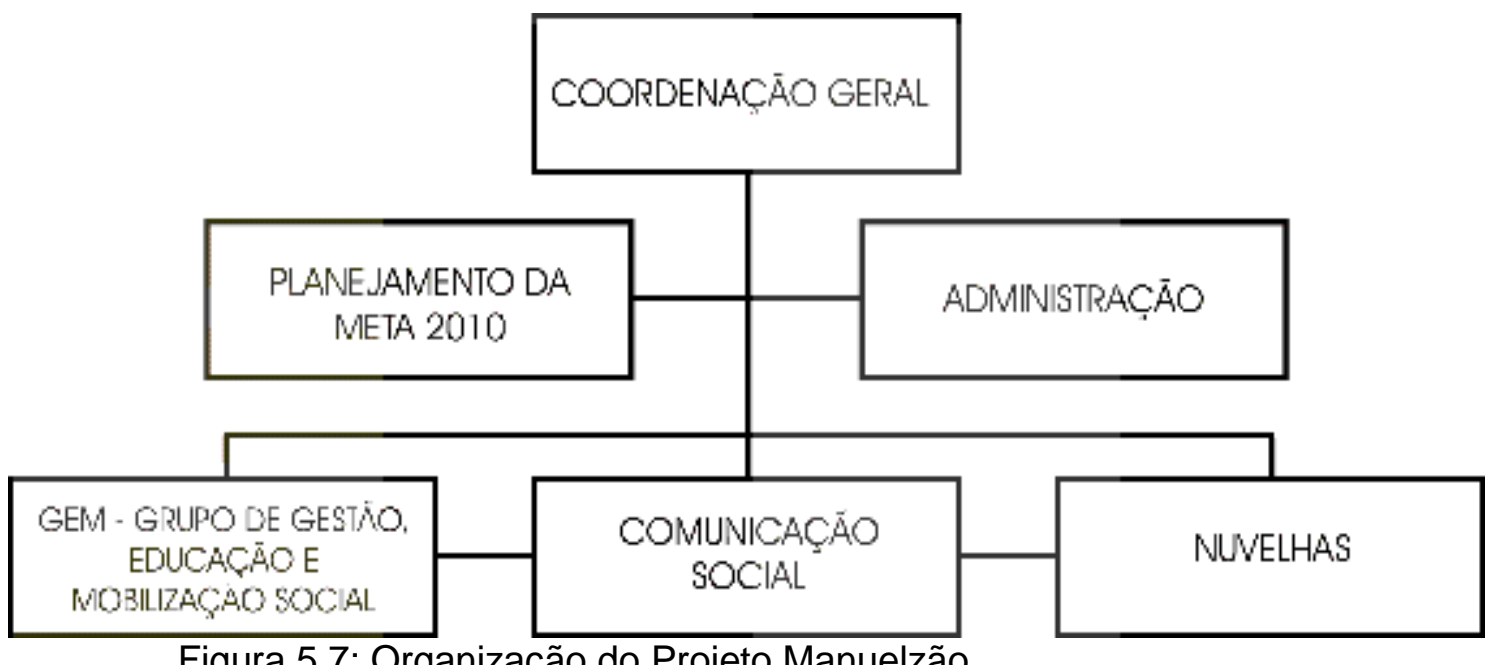

Fonte: PROJETO MANUELZÃO, 2015(c)

Mais vinculado aos propósitos de intervenção em um ambiente de políticas públicas, provavelmente se torne mais relacionado a este trabalho analisar que o Projeto Manuelzão tem seu posicionamento institucional também voltado às mesmas, o que poderia ser considerado um de fundamentos para o reconhecimento público: estar inserido nas agendas de discussão de empreendimentos que ocorrem na bacia, com predominância para a $\mathrm{RMBH}^{52}$.

Sem dúvida que o fato de possuir um corpus de atuação formada em sua grande maioria por pessoas de formação das áreas de exatas e biológicas também pode, caso não se tome devidas

$50 \quad$ Em uma coleta de dados via a página institucional do projeto, contabiliza-se em torno de 70 indivíduos envolvidos na organização das atividades desde a mobilização até os setores financeiros.

51 Como exemplo de sua operacionalização valeria enfatizar que as principais linhas de ação do Projeto seriam: Mobilização, Arte e Cultura, Educação, Comunicação e Pesquisa - vinculadas com a própria estrutura organizacional da entidade.

52 De maneira mais clara tem-se as discussões acerca da canalização de rios, a questão do tratamento do lixo e, mais atualmente, a temática da "Linha Azul", em contraposição à chamada "Linha Verde" em implantação desde 2006 na capital, Belo Horizonte, com vistas ao reordenamento de várias linhas viárias da região.

Programa de Pós-graduação em Saneamento, Meio Ambiente e Recursos Hídricos da UFMG 
reflexões sobre isto $^{53}$, se tornar uma organização futura com níveis crescentes de burocratização de atividades - apesar de até o momento não houve este alarme.

Por outro lado, esta constatação nos leva à seguinte indagação de que se é a estrutura montada (originária de uma faculdade de Medicina) que não permite muito a participação das áreas de humanas (o que parece pouco provável dado o caráter difuso da temática ambiental) ou se, na verdade, as discussões sobre a gestão de recursos hídricos em formatos de organismos de bacia ainda não foram devidamente incorporadas aos cientistas sociais enquanto participação e análise crítica.

São questão que já foram levantadas também em Beck (2009), Giddens (2010) e principalmente em Norgaard (1992), ao colocar que a ciência ambiental é, antes de tudo, uma ciência social. Porém esses autores colocam que o próprio campo de estudo ambiental estaria ainda a demandar sua consolidação científica, por uma vertente, e acadêmica, por outro, em termos de uma interação de conhecimentos mais ampla (LISBOA, 2012). O que remete também às colocações de Demo $(1985$, p. 29) ao indicar que

Sendo a ciência também um fenômeno histórico, é propriamente um processo. O conceito de processo traduz a característica de uma realidade sempre volúvel, mutável, contraditória, nunca acabada, em vir-a-ser. (...) Em ciência estamos sempre começando de novo.

Certamente também que o fato de existir há menos de duas décadas traz ao Projeto Manuelzão as sequelas inerentes de um processo que é de implantação para o longo prazo como o é a da mobilização social. Ainda mais para a ação em um Estado como o brasileiro, com forte vinculação ao economicismo e com as demandas urbanas em crescimento. Em termos gerais isto significaria que o próprio projeto está paulatinamente em processo de inserção dentro das agendas públicas estadual e regionais, necessitando de que haja novos agentes de diversas formações em seus quadros estratégicos e operacionais (LISBOA et al., 2008).

De fato, o Projeto Manuelzão possui um caráter de profissionalização que têm se mostrado dinâmico, mais ainda em relação à sua capacidade de comunicação social inter e supra bacia hidrográfica, com a produção de vários documentários, folhetos e afins que, no campo,

\footnotetext{
53 Como a incorporação necessária das discussões das ciências humanas e sociais, visto que não foi encontrado nenhum sociólogo, antropólogo, cientista político ou historiador (dentre outros perfis, certamente) nos quadros da entidade. O mesmo perfil da falta de professionais formados em ciências humanas também é existente na AGBPV.
}

Programa de Pós-graduação em Saneamento, Meio Ambiente e Recursos Hídricos da UFMG 
possuem um valor simbólico e de concretização de propostas evidente. Isto porque visa permitir um reconhecimento das populações do entorno de sua própria realidade de vida e de que a construção coletiva pode ser exercida. Mesmo em cenário de curto prazo para a ação (mobilização) quanto para os resultados (melhora na relação quantidade e qualidade hídrica e social).

Como já citado anteriormente na análise comparativa de casos nacionais, essa ação via novas concepções ("framing”) se mostrou bastante positiva no caso do Projeto Manuelzão e do próprio CBHRV para fundamentar uma respeitabilidade organizacional e institucional que muitos movimentos sociais não conseguem empregar. E isso aconteceu justamente porque os esforços iniciais foram capazes de apresentar resultados para problemas específicos (ABERS, 2007; ABERS e KECK, 2013; LISBOA et al., 2008).

Mais, como afirmou um dos representantes do CBHRV: "O sucesso do Projeto Manuelzão não separou a água só para o ser humano; ao invés de uma visão antropocêntrica, teve uma visão biocêntrica, maior, mais inclusiva".

\subsubsection{A "Meta 2010" e a "Meta 2014" como catalisadoras de ações}

A proposta de gestão do Rio das Velhas se encontra intimamente baseada na sua ação de longo prazo, estabelecida em assembleias variadas do comitê como compromisso acordado entre usuários de águas da bacia, sociedade civil organizada e os representantes públicos. Esse posicionamento de atuação tentou se aproximar da legislação mais pertinente e recente à época, destacadamente a Lei Federal n 9.433 de 1997 e a Lei Estadual n 13.199, de 1999. Nesse processo de aproximação junto ao poder público, o Projeto Manuelzão, e, por influência, o próprio comitê, criou um processo de diálogos com o poder executivo e, principalmente, legislativo, que acabou por se tornar um diferencial de ambos (LISBOA, 2012).

Normalmente, como pôde ser visto nos estudos de casos, os CBHs se orientam na direção do estabelecimento de metas e alianças junto aos representantes do executivo mais do que no legislativo, nas instâncias de poderes políticos. Muito advindo da liderança de Apolo Heringer Lisboa, que viu nesse posicionamento uma forma mais adequada de se tratar os projetos em andamento na bacia para o longo prazo, novos acordos institucionais foram criados.

Programa de Pós-graduação em Saneamento, Meio Ambiente e Recursos Hídricos da UFMG 
Dois deles se destacaram inclusive ao nível estadual, não apenas da bacia hidrográfica do Rio das Velhas, porque foram incorporados como "projetos estruturadores" (que definem políticas públicas específicas) junto ao governo do estado de Minas Gerais. Por exemplo, no ano de $2003^{54}$ houve a assinatura do governador do Estado de Minas na época, Aécio Neves (Partido da Social Democracia Brasileira - PSDB), que se comprometeu a implantar a proposta enquanto política pública de destaque na agenda de trabalho.

O projeto, denominado de "Meta 2010 - Navegar, nadar e pescar no Rio das Velhas até 2010", acabou por ser inserido também nas discussões do que viria a ser o "Plano Diretor de Recursos Hídricos da bacia do Rio das Velhas", de 2005 (ver CAMARGOS, 2005). A Meta 2010 foi encaminhada por uma comissão que teve o governo estadual mineiro juntamente com as prefeituras dos municípios de Belo Horizonte e Contagem e das cidades da bacia do Ribeirão da Mata, IGAM e outros órgãos e instituições.

Tanto que vale relembrar a já citada DN 07/04 do comitê, de 2004, quando da presidência do próprio Apolo, que citava a necessidade de maior integração institucional via um projeto com data de início e fim, com parceiros determinados:

Considerando que o Termo de Compromisso do Governo do Estado de Minas Gerais, assinado em 22 de março de 2004 e publicado em 23 de março de 2004 tem como objetivo conjugar os esforços dos representantes do Poder Público, do setor empresarial e da sociedade civil a fim de atender às metas de qualidade para o enquadramento dos corpos de água em Classe 2, no trecho da confluência com o Ribeirão Sabará até a confluência com o Rio Jaboticatubas até o ano de 2010, recuperando espécies de peixes que já povoaram o rio das Velhas e propiciando à comunidade da sua bacia a possibilidade da pesca, do lazer (natação e navegação) do turismo e o desenvolvimento socioeconômico sustentável da bacia.

Considerando que durante a fase de elaboração do Plano Diretor de Recursos Hídricos identificou-se a necessidade e oportunidade de o CBHVELHAS estabelecer imediatamente um diálogo contínuo, envolvendo os atores sociais estratégicos da bacia, a fim de viabilizar acordos necessários para garantir a melhoria da qualidade das águas do rio das Velhas;

\section{(...)DELIBERA:}

Art. $1^{\circ} \mathrm{O}$ Comitê da Bacia Hidrográfica do Rio das Velhas promoverá esforços para celebrar o primeiro instrumento jurídico com sua interveniência, tendo como partícipes a COPASA, o Município de Belo Horizonte, o Município de Contagem e a SEMAD como procedimento formal inicial da construção de acordos para a melhoria da qualidade da água do rio das Velhas.

54 Como consequência também da "Expedição Manuelzão desce o Rio das Velhas", realizada também no ano de 2003 pelo CBHRV e Projeto Manuelzão.

Programa de Pós-graduação em Saneamento, Meio Ambiente e Recursos Hídricos da UFMG 
$\S 1^{\circ} \mathrm{O}$ instrumento jurídico a que se refere este artigo é denominado Termo de Cooperação Técnica, e sua minuta encontra-se no Plano Diretor de Recursos Hídricos da Bacia Hidrográfica do Rio das Velhas.

Neste se evidência a proposta geral de direcionamento da articulação institucional e social para o Rio das Velhas e sua bacia hidrográfica, com suas atualizações previstas para ocorrerem até o ano de 2010, contabilizando-se aí os variados cenários que são possíveis de acontecer no longo prazo da gestão (LISBOA, 2012; COSTA, 2008). O foco principal foi o peixe como indicador socioambiental, onde ele tomou a conotação de representante da capacidade de recuperação não só biológica da bacia, mas, na verdade, a recuperação social e simbólica da água como mais do que um recurso e sim um bem natural de índice de qualidade de vida (PROJETO MANUELZÃO, 2010; LISBOA, 2012; LISBOA et al. 2008). Ou como descrito em GOULART (2005, p. 60):

A água trouxe mais este presente: o peixe seria o principal indicador da qualidade das águas e do meio ambiente no território da bacia do Rio das Velhas, permitindo avaliar os resultados obtidos em nosso trabalho. (...) Peixe este representando a biodiversidade histórica dos ecossistemas regionais da bacia, qualidade de vida e de meio ambiente.

Nesta direção, a proposta de se "Navegar, nadar e pescar no Rio das Velhas até 2010”, que tinha variados índices de poluição, foi considerada muitos setores (talvez com mais ênfase nos usuários industriais) como ingênua. Porém, essa proposta visou, de acordo com LISBOA (2012) e também nas pesquisas realizadas em campo, exercer pressão social e política sobre o poder público e órgãos ambientais da época:

As políticas públicas conquistadas neste período mostram como o Estado e os diferentes atores assumiram compromissos institucionais novos, de forma cooperativas, ainda que se possa lamentar a fraqueza ou mesmo cumplicidade do Estado na não efetivação de todos estes compromissos nos prazos previstos. Como exemplo dessas conquistas citamos principalmente a Meta 2010: Navegar, Pescar e Nadar no Rio das Velhas, tornada programa estruturador do Estado. Essa Meta, proposta inicialmente pelo $\mathrm{PMz}$, tornou-se núcleo do Plano Diretor do $\mathrm{CBH}$ Velhas, aprovado em 2004. Outra proposta foi a dos parques lineares, ou ciliares, proposta para erradicar as canalizações de rios em $\mathrm{BH}$ e assumida pelo prefeito Célio de Castro que aprovou o Plano Diretor de Drenagem de Belo Horizonte, dando início ao DRENURBS. Outro exemplo foi a Deliberação Normativa (DN) $\mathrm{n}^{\circ}$ 95/2006 do COPAM, que restringe as possibilidades das canalizações de cursos d'água em Minas Gerais, no mesmo sentido da anterior. Da maior relevância está a criação dos subcomitês de bacia, através da $\mathrm{DN} \mathrm{n}^{\circ} 02 / 2004$ do CBH Velhas, como proposta de descentralização da gestão do rio das Velhas, primeiro exemplo no Brasil. Através da DN n ${ }^{\circ}$ 1/ 2008, conjunta entre COPAM e CERH, como um dos parâmetros para Enquadramento das águas, foi definido o biomonitoramento na bacia do rio das Velhas, uma proposta pioneira no Brasil, já implementada pelo PMz há mais de dez anos na bacia do Velhas. 
Isso pôde ser notado (novos compromissos) por exemplo, quando do lançamento oficial da estação de tratamento (no primeiro semestre de 2006) que contou com a presença do governador Aécio Neves, que foi fortemente cobrado para que as fossem cumpridas em prazo hábil $^{55}$. Mais ainda, esta meta de gestão com foco em um resultado palpável de melhora na qualidade das águas da bacia foi bem recepcionada em diversos eventos pelo país, enquanto um reconhecimento de sua proposta de gestão participativa ${ }^{56}$.

Consequentemente, de forma a não perder as conquistas iniciais obtidas pela Meta 2010, houve a proposta da continuidade das ações, agora via a Meta 2014, o que refletiu bastante o cenário político institucional da época, como comprova o próprio Projeto Manuelzão, ao expor a transição entre os dois projetos:

Em 2003, durante a Expedição que desceu o Velhas até o São Francisco, propusemos a Meta 2010, de Navegar, Pescar e Nadar no seu trecho mais poluído, na passagem do rio pela Região Metropolitana de Belo Horizonte (RMBH). O então governador de Minas Aécio Neves a assumiu em março de 2004, por sugestão nossa. E posteriormente a transformou em Programa Estruturador do Estado. Foram feitos investimentos políticos, administrativos e financeiros tanto pelo Estado, quanto pelo Projeto Manuelzão/UFMG, diversas prefeituras e algumas empresas. Mas o ator mais eloquente foi a sociedade civil ao conseguir que o Estado encampasse sua proposta.

Fazendo agora um balanço da Meta 2010, ela teve 60\% de sucesso. Nadamos com segurança em Santo Hipólito, na região de Curvelo, no médio curso. Nesta região é comemorado o milagre da multiplicação dos peixes e da ressurreição do rio. Dados do biomonitoramento do NUVELHAS/Projeto Manuelzão/UFMG, que vem sendo realizado há mais de dez anos, comprovam que peixes antes ausentes estão hoje chegando à RMBH. No geral o rio melhorou muito. Mas ainda não conseguimos a vitória de poder nadar na RMBH com segurança. Por isso, para não deixar o vazio tomar conta, e fazer com os parceiros as reformulações necessárias na gestão, lançamos a Meta 2014, para finalmente podermos nadar na RMBH e ter aí um rio cheio de peixes da bacia do São Francisco. Algumas diretrizes para esse novo momento estão previstas em documento assinado dia 14 de Agosto, às margens do rio das Velhas, pelo governador Antônio Anastasia, por Aécio Neves, por diversos prefeitos - entre os quais o prefeito de BH Márcio Lacerda, os coordenadores do Projeto Manuelzão, secretários de Estado, deputados, Núcleos do Projeto Manuelzão e pessoas presentes ao evento. (PROJETO MANUELZÃO, 2012).

\footnotetext{
55 Refere-se aqui ao lançamento oficial da Estação de Tratamento de Esgoto do Ribeirão Arrudas (ETE Onça), em Belo Horizonte.

56 A título de exemplo, em 2007 a proposta recebeu o título de "Destaque Estadual" do Prêmio Brasil de Meio Ambiente, realizado pelo setor midiático, para empreendimentos de vinculação entre atividades produtivas e conservação ambiental.
}

Programa de Pós-graduação em Saneamento, Meio Ambiente e Recursos Hídricos da UFMG 
A grande questão da Meta 2014 foi justamente de enfatizar uma visão alternativa de intervenção nos corpos d'água, com a relevância das discussões sobre uma proposta de recuperação dos espaços ambientais, principalmente urbanos. A visão era de que a recuperação hídrica seria alcançada ao mesmo tempo em que a revitalização dos corpos d'água e da maior participação social ocorresse.

Interessa notar que tanto ambas as Metas são consideradas de forma explícita, em termos de seus resultados, na atualização do PDRH do CBHRV, ocorrida em 2015:

O PDRH 2015 incorpora os ganhos obtidos pelo plano da Meta 2010-2014, sinalizando que: houve avanços importantes no saneamento ambiental principalmente na região metropolitana, onde cerca de $60 \%$ dos esgotos estão sendo coletados e tratados; houve um aumento significativo da mobilização social, já incorporado dentro da estrutura do comitê de bacia através dos subcomitês; a revitalização se tornou um projeto estruturador de governo, embora ainda limitado a alguns segmentos do mesmo; os peixes voltaram a habitar a região do médio e alto Rio das Velhas em decorrência destas ações. Portanto o grande norteador do PDRH 2015 continua sendo a meta de nadar e pescar no trecho metropolitano do Rio das Velhas, que permanece como o epicentro da degradação (...) - CBHRV (2015(a), p. 17).

\subsection{O Comitê da Bacia Hidrográfica do Rio das Velhas (CBHRV)}

O Comitê da Bacia Hidrográfica do Rio das Velhas (CBHRV) foi criado a partir do Decreto $\mathrm{n}^{\circ}$ 39.692, de 29 de junho de 1998, por atribuição do governador do estado de Minas Gerais à época, o engenheiro mecânico, Eduardo Azeredo, do Partido da Social Democracia Brasileira (PSDB). Contextualmente o momento era o do início da implementação de políticas públicas consideradas como de cunho neoliberal no território mineiro, o que significa a emergência do setor privado na economia do estado mineiro e nas discussões sobre crescimento econômico, institucional e social (DULCI, 1999; COSTA, 2008; CUNHA, THEODORO, 2014; JÚNIOR, 2013; MOREIRA, 2013; SEDRU, 2011).

Configurar este momento histórico é necessário na medida em que esse comitê surgiu justamente das iniciativas de parcerias entre o governo brasileiro/mineiro e agências multilaterais de investimentos. No caso, o Banco Interamericano de Desenvolvimento (BID) foi a instituição responsável por operar a proposta de revitalização ambiental e hídrica encaminhada pelo Estado. Especificamente, o Comitê da Bacia Hidrográfica do Rio das Velhas (CBRHV) foi decretado com a finalidade de:

Art. $1^{\circ}$ - Fica instituído o Comitê da Bacia Hidrográfica do Rio das Velhas, com a finalidade de promover, no âmbito da gestão de recursos hídricos, a viabilização 
técnica e econômica-financeira de programa de investimento e consolidação de política de estruturação urbana e regional, visando ao desenvolvimento da Bacia.

Com já indicado, ele, comitê, surgiu em um momento em que o contexto da gestão institucional de recursos hídricos havia passado por sua primeira grande reforma desde o arcabouço jurídico de 1934, quando da promulgação da Lei Federal n 9.433 de 1997. Essa reformulação na forma com a gestão era pensada, de um sistema burocratizado para um sistema mais participativo e democrático, foi fundamental para que houvesse um ambiente jurídico mínimo propício para que organismos de bacia surgissem. Tanto que logo após o surgimento do CBHRV em 1998, houve a promulgação da Política Estadual de Recursos Hídricos via a Lei Estadual n 13.199, de 1999.

\subsubsection{Câmaras Técnicas}

Um dos itens de maior utilização e rotinização de procedimentos nos $\mathrm{CBHs}$ mineiros e brasileiros tem sido o da instalação de Câmaras Técnicas (CTs) como instâncias também de discussões temáticas vinculadas com a gestão hídrica de cada região. Tanto que o CBH Pará, CBH Paracatu ou o CBH Doce também possuem o modelo da utilização das CTs como instrumento administrativo e jurídico para a organização de suas atividades, inclusive para a gestão de seus recursos políticos e econômicos. Não diferente desse posicionamento, o CBHRV também possui em sua estrutura a possibilidade de que haja um contínuo suporte intelectual, técnico, administrativo, jurídico e comunicativo não-remunerado e não-vinculado diretamente ao comitê (em termos da composição de seus membros). O que significa que qualquer cidadão pode pleitar uma vaga dentro das CTs, que, no caso do comitê pesquisado, possuem 8 membros titulares e 8 membros suplentes, que são representantes dos 4 segmentos componentes do mesmo. De forma geral, a definição oficial das mesmas é que

As Câmaras Técnicas são colegiados formados a partir das instituições que compõem a plenária do $\mathrm{CBH}$ Rio das Velhas. Elas refletem o modelo de organização paritário do Comitê e tem como finalidade discutir com o tempo e a dinâmica que julgam necessárias as discussões temáticas, técnicas e complexas. (CBHRV, 2014(a)).

O que indica que as CTs são espaços previstos em diversas Deliberações Normativas do comitê, a partir do ano de 2006, quando 3 câmaras foram homologadas em documentação própria e no mesmo dia 10 de fevereiro do referido ano, gerada a partir da decisão ocorrida via reunião plenária, na $28^{\mathrm{a}}$ reunião ordinária de 02 de maio de 2005, quando da presidência de Apolo Heringer Lisboa. E em 2011, quando a última das 4 câmaras atuais foi homologada, sendo que todas são de caráter permanente de atuação. Objetivamente, tem-se a seguinte estrutura organizacional das câmaras:

Programa de Pós-graduação em Saneamento, Meio Ambiente e Recursos Hídricos da UFMG 
Câmara Técnica Institucional e Legal (CTIL): foi homologada via a DN 01/06. Ela é a instância responsável por verificar o aspecto legal e institucional de todas as atividades do comitê, além de adequar as decisões do mesmo às determinações legais. Possui competência ampla de atuação inclusive sobre o trabalho das outras câmaras, uma vez que deve à essas, assessorar, dentre suas várias funções (Art. $2^{\circ}$ ). De forma prática, há um movimento de indicação inicial se os projetos estão de acordo no comitê, as câmaras realizam seus trabalhos e a CTIL reverifica se os procedimentos jurídicos procedem. Sua proeminência na harmonização das normas existentes e da atuação do comitê pode ser identificada, mais recentemente, na DN 02/15, que, como já citada, aprovou a atualização do PDRH do mesmo em seu

Art. $2^{\circ}$ Fica delegada à Câmara Técnica Institucional e legal - CTIL a função de adequação do Plano Diretor de Recursos Hídricos da Bacia Hidrográfica do Rio das Velhas, de modo a incorporar revisão de redação.

Câmara Técnica de Outorga e Cobrança (CTOC): foi homologada via a DN 02/06. Tem como competência a análise e deliberação de processos de outorga, ou melhor, a concessão pública para utilização de usos múltiplos de recursos hídricos. Nela são discutidos como (fórmulas de cálculo), onde, por quanto tempo, por qual valor e para qual fim os recursos hídricos do CBHRV devem ser utilizados em cada caso em particular (Art. $2^{\circ}$, principalmente o Inciso II). Teve um crescimento recente em importância dentro da dinâmica do comitê no sentido de que as demandas por captação de água, com destaque na RMBH, têm também crescido nos últimos anos. Outro fato é que por poder impedir a liberação de outorga relativas ao território da bacia hidrográfica do Rio das Velhas, a CTOC tem sido por várias vezes contestada pelas partes interessadas na utilização dos recursos hídricos - mesmo que o IGAM seja o principal responsável pelo gerenciamento dos mesmos em Minas Gerais.

Câmara Técnica de Planejamento, Projetos e Controle (CTPC): foi homologada via a DN 03/06. Tem vinculação direta com a orientação ao comitê sobre o seu planejamento institucional e organizacional, principalmente em relação ao Plano Diretor de Recursos Hídricos, lançado em 2005 e atualizado em 2015. Consequentemente, é a instância responsável pelo acompanhamento e execução dos projetos e das demandas formais existentes no CBHRV. Atualmente o comitê possui um rol de projetos: Plano Municipal de Saneamento Básico (PMSB); projetos hidroambientais (recuperação de nascentes, por exemplo); biomonitoramento; controle de cianobactérias; plano de manejo; elaboração de termos de referência e a própria atualização do plano diretor, com já indicado. 
Câmara Técnica de Educação, Mobilização e Comunicação (CTECOM): diferentemente das CTs anteriores, esta câmara foi homologada apenas em 2011, via a DN 02/11, quando da presidência de Rogério Sepúlveda. Surgiu em um contexto de crescente pressão para haver uma câmara específica para promover a comunicação interna do comitê e, também, do comitê em relação à população em geral e instituições relativas ao tema/comitê. Visou desde o início ser a câmara responsável por comunicar e mobilizar tanto o comitê como também a AGBPV, em termos dos projetos em andamento ou a serem contratados (o que é previsto em seus Arts. $\left.1^{\circ}, 2^{\circ}\right)$.

\subsubsection{A gestão via subcomitês}

Para uma melhor compreensão de que como CBHRV organizou sua gestão de recursos hídricos, é demandada que sua opção de ação seja descrita como possibilidade de identificação dos limites e potencialidades de suas práticas. No caso da gestão via subcomitês é inegável (inclusive nas entrevistas realizadas) que sua origem remonta ao modelo de gestão local criada no Projeto Manuelzão (Núcleos Manuelzão) desde antes da década dos anos 2000s (LISBOA, 2012; COSTA, 2008). Porém, a ressaltar, não podem os dois serem considerados como a continuidade do mesmo modelo, pois

(...) os Núcleos teriam participação no subcomitê de sua área geográfica de atuação, representando a sociedade civil. Estava muito claro nos documentos que não era o caso dos Núcleos se transformarem em subcomitês, pois estes pertenciam a outra estrutura, ao Estado, vinculados ao CBH-Velhas. (LISBOA, 2012, p. 160).

O próprio autor citado já indicava, inclusive, que a principal atuação do Projeto Manuelzão havia sido justamente a constante atuação via subcomitês:

Sobre a formação dos subcomitês, vale analisar alguns aspectos dessas unidades e o objetivo de sua criação. Estes foram pensados como estratégias que pudessem viabilizar a concretude de uma das metas do $\mathrm{PMz}$ que era incentivar uma gestão ambiental integrada, descentralizada e participativa (...). (LISBOA, 2012, p. 155).

Outra indicação de que o Projeto Manuelzão teve influência na proposta da gestão via subcomitês foi a promulgação da Deliberação Normativa do CBHRV, $\mathrm{n}^{\circ}$ 02/04, quando da presidência do próprio Apolo Heringer Lisboa. Adiciona-se aqui também os estímulos à organização dos organismos de bacia via a Lei Federal n 9.433 de 1997, principalmente no que tange à composição com participação social por segmentos, por exemplo. Os subcomitês, diferentemente do comitê em si, não possuem poder deliberativo, sendo somente consultivo o seu poder político de alcance. Inclusive, no Parágrafo único do Art. $2^{\circ}$, é colocado que "É 
vedada a atribuição de personalidade jurídica aos subcomitês.”. Tal caracterização da impessoalidade jurídica também pode ser encontrada no modelo de gestão via CBHs (CBHPCJ, 2016), que também não a possuem, ou nem mesmo bens, funcionários, ou equipe técnica própria.

As competências dos subcomitês são consideradas no sentido de "pronunciar-se, mediante solicitação do Comitê da Bacia Hidrográfica do Rio das Velhas, sobre as questões relacionadas aos recursos hídricos em sua área de atuação - Art. $3^{\circ}$, Inciso II.

De acordo com a Figura 5.8, até o ano de 2012, o CBHRV possuía 14 subcomitês em sua área de atuação, principalmente na sua região metropolitana onde, como já descrito, possui a maioria das atividades produtivas da bacia (CBHRV, 2015(a)). Ao mesmo tempo, entretanto, a atuação via subcomitês tem sido visto como possível avanço para maior representatividade e articulação da população local (CBHRV, 2014(a)). 


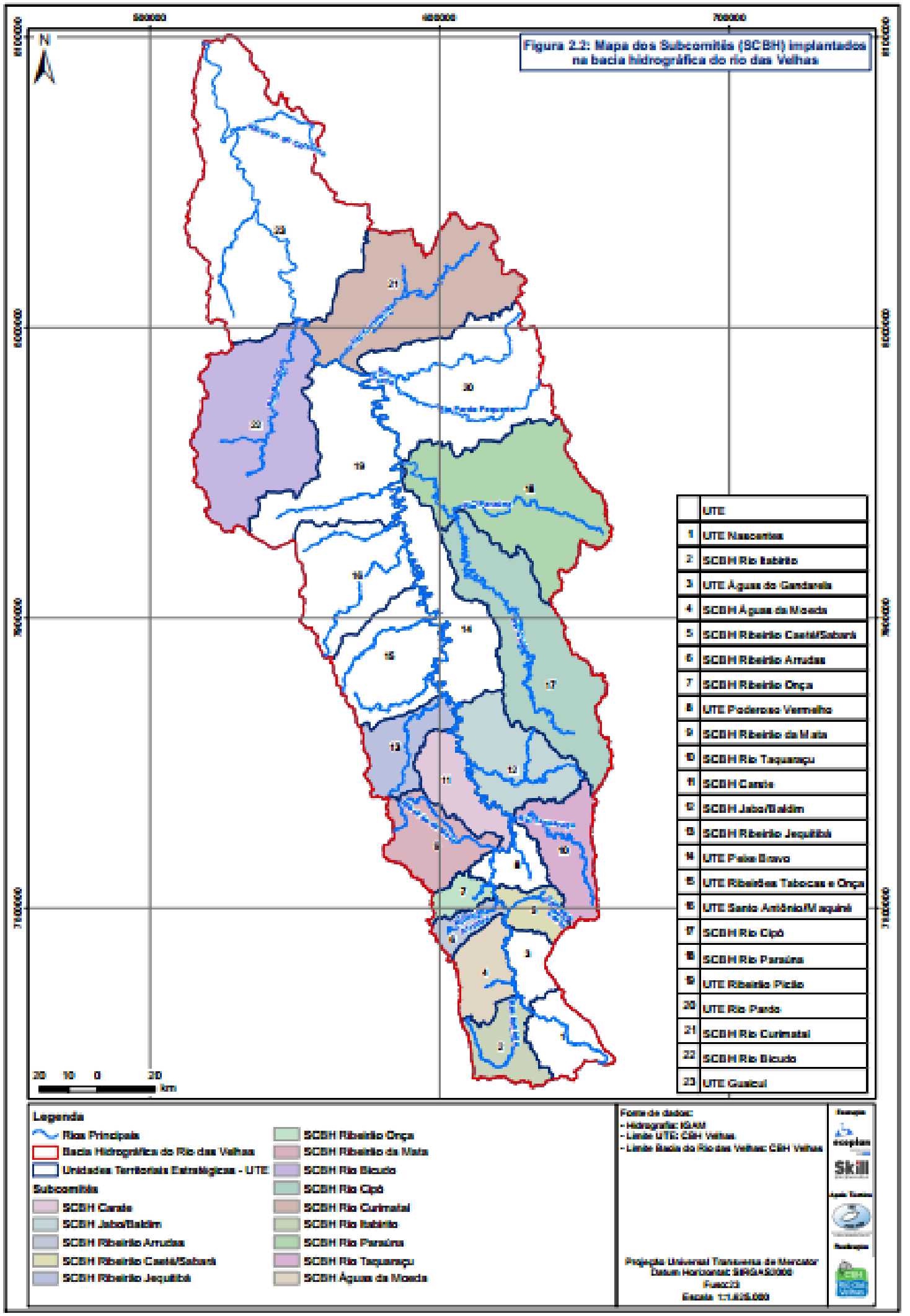

Figura 5.8: Subcomitês da bacia hidrográfica do Rio das Velhas Fonte: CBHRV 


\subsection{Sobre os conflitos identificados no CBHRV}

Especificamente sobre os conflitos relacionados ao Rio das Velhas, cabe iniciar pela noção de que a região sempre foi e continua a ser um local de disputas políticas e/ou econômicas. É parte de sua história de desenvolvimento a ocorrência de vários tipos de conflitos. A começar pela cobiça gerada quando da época inicial da mineração e da extração dos recursos naturais na região central de Minas Gerais.

Nos relatos de BURTON (1977), no final do século XVII e início do século XVIII são descritas as áreas relativas às atividades de garimpo, como também de pesca e corte de madeira para os mais diversos usos. Isso gerou conflitos de ordem interna entre os povos indígenas existentes na região nesse período, como de ordem externa com os interesses da coroa portuguesa em controlar a região (CBHRV, 2011; DULCI, 1999). Uma vez que já foram discutidos os conflitos sobre a gestão dos recursos hídricos existentes no estado de Minas Gerais, e a reafirmar a identificação maior dos mesmos nas regiões oeste e noroeste, cabe aqui agora as discussões referentes ao CBHRV em si. Isso é importante para que haja uma possibilidade de debate sobre o perfil de gestão que o comitê tem apresentado para lidar com seus conflitos e quais soluções foram encaminhadas. Mais ainda, tais identificações permitem a criação de um modus operandis dos organismos de bacia envolvidos em relação ao tempo de resposta e de transparência nas mesmas.

1. Processo eleitoral $($ Outubro de 2002) $=$ Houve eleição do professor da Faculdade de Medicina, Apolo Heringer Lisboa, para o mandato de 2003-2005. Porém o secretário de estadual de meio ambiente na época, sr. Celso Castilho, questionou o processo de habilitação eleitoral do comitê. O fato é que a figura política e de liderança de Apolo foi direta e indiretamente questionada pelos setores governamentais e principalmente de usuários.

Com isso o processo eleitoral foi inicialmente impugnado, o que gerou um mal-estar entre governo e sociedade civil, que estava altamente mobilizada para a referida eleição. Consequentemente, houve protestos e pressão social junto aos órgãos gestores, o que acabou por fazer com que a posse da nova diretoria eleita fosse adiada em quase um ano em suas atividades:

"Houve uma tentativa de melar o processo, um golpezinho de setores ligados ao usuário, desconfiados da participação do Projeto Manuelzão e da minha liderança. 
Isto por que eu sou ligado a uma liderança anterior político partidária, já estive exilado, isto despertou temor no pessoal que dependia do Velhas para obter outorga. E eles tentaram, fizeram um recurso quando já havia decorrido o prazo e a eleição foi adiada em pleno processo de votação. Nós mobilizamos prefeituras e Ongs e fomos ocupar a secretaria do meio ambiente. O secretário da época estava em Brasília e voltou no dia seguinte, viu aquela situação e voltou atrás de sua decisão. No dia seguinte, saiu no Diário Oficial uma mudança, mantendo as eleições para a outra semana e ninguém lançou chapa e nós vencemos as eleições por unanimidade. Mas eles não ficaram muito felizes e houve muita pressão para mudar este resultado. Eu esperei nove meses para tomar posse e o comitê do Velhas ficou nove meses desativado." (Fonte: entrevista, representante sociedade civil, fevereiro de 2007) - COSTA (2008).

Cabe descrever que a figura de Apolo foi fundamental no processo de articulação do CBHRV, não só por assumir a presidência do mesmo, mas porquê foi um ator político nos bastidores dos processos de tomadas de decisão. Ele como representante da sociedade civil via Projeto Manuelzão/Instituto Guaicuy fez com que a dinâmica existente no comitê realmente mudasse, uma vez que, como verificado em entrevista realizada:

“(...) melhorou demais o CBH com a atuação do Projeto Manuelzão, porque na época do Paulo Maciel, nem tinha reuniões, reuniões efetivas. E também o Velhas se tornou referência em nível institucional, pois vários outros comitês não tem atuação. E tudo o que o governo mais quer, se possivel, é acabar com os CBHs. Porque? Porque ele coloca várias condicionantes que não são cobradas; não há um banco de dados ou controle pelo IGAM, por exemplo, sobre as ações das mineradoras; melhorou muito mais o CBH com as últimas quatro gestões, a do Apolo e Rogério. $O$ comitê batalhou mais." (Fonte: entrevista, representante sociedade civil, janeiro de 2014).

$\mathrm{Na}$ realidade, o valor das lideranças nos processos de gestão tem sido muito considerado, como elo de diálogos entre as partes envolvidas, mas com a credibilidade necessária para tanto. Pois empoderam as partes interessadas que são ou estão enfraquecidas em processos de tomadas de decisão (ANSELL e GASH, 2007). É também aqui uma verificação daquilo que ABERS e KECK (2013) enfatizam como a "practical authority" dos indivíduos líderes nos processos, que legitimam e são legitimados nos mesmos. Isso porque demonstram em todos os momentos necessários o seu valor como tomadores de decisão, assim como também pelos resultados conseguidos.

Nesse sentido, figuras como a de Apolo Heringer Lisboa (tanto como membro do Projeto Manuelzão, como também como professor da UFMG) são necessárias como 
líderes orgânicos dos processos de discussão, na medida em que surgiram e se estabeleceram "de dentro" dos movimentos sociais. E não porque foram impostos ou por serem membros dos quadros estabelecidos de uma organização social ou governamental.

2. Processo eleitoral (dezembro de 2007) $=$ Nesse processo eleitoral os questionamentos foram diferentes do que no item anterior. Agora já estabelecida como uma organização de liderança do processo de gestão via comitê no Rio das Velhas, o Projeto Manuelzão passou a ser questionado como única presidência. Pois se uma pessoa física não poderia ser eleita por mais de uma vez, com uma reeleição, tal definição não estava determinada para a pessoa jurídica (COSTA, 2008; CBHRV, 2015(a); CAMARGOS, 2005). Essa lacuna permitiu ao Projeto Manuelzão lançar mais uma chapa para a presidência, via a pessoa jurídica do Instituto Guaicuy e com o engenheiro civil Rogério Sepúlveda como candidato. O mesmo foi aprovado por consenso na plenária, mas não é possível afirmar o mesmo no sentido de um conceito ideológico-administrativo.

Para alguns membros, a reeleição do Instituto Guaicuy foi questionada, não necessariamente de maneira conflitante, tal como é possível se identificada em COSTA (2008):

"Foi chapa única e todos os membros votaram favoráveis à reeleição, por isto que todo mundo acatou, foi consenso e tal. Mas se por exemplo tivesse na deliberação normativa que a entidade não pode ter 3 mandatos consecutivos, talvez isto influenciaria a ter uma nova chapa". (Fonte: Entrevista, representante poder público estadual, dezembro de 2007).

A solução proposta foi a instalação de uma "diretoria colegiada" para poder acontecer uma maior participação dos membros líderes do comitê, sendo a mesma composta por 8 membros, com 2 membros de cada segmento. De acordo com a interpretação de uma liderança do poder público estadual,

“(...)houve a criação da Diretoria Colegiada, o que trouxe alguns beneficios, principalmente porque a representatividade da sociedade é maior e tem um grupo mais heterogêneo na representação dos seus membros. Mas os conflitos ainda estão lá. Mas, claro, atualmente a relação está mais clara e com papéis mais claros e com a Peixe Vivo atuando mais." 


\section{Fechamento da sede do comitê e da Equipe de Mobilização Social (Outubro de}

2012) $=\mathrm{O}$ ano de 2012 foi aquele marcado por um recrudescimento nas relações e situações conflituosas entre o CBHRV e a AGBPV, muito por conta das definições sobre aplicações de recursos em projetos, como também pelas linhas de atuação das diretorias das duas organizações. De forma recorrente o ambiente foi de incerteza e de demanda por rapidez, por parte do comitê, em relação às ações das agências (situação citada em algumas entrevistas) e também do órgão gestor, o IGAM.

O momento crucial desses embates se deu quase no final do ano de 2012 quando houve o questionamento do IGAM acerca da atuação da equipe de mobilização social do comitê, que estaria atuando de forma executiva. Isso seria função apenas da AGBPV, que é a responsável pelas ações práticas determinadas e referendadas nas reuniões plenárias.

Como os percentuais de aplicação dos recursos advindos da cobrança pelos usos múltiplos dos recursos hídricos são determinados em apenas 7,5\% para custeio operacional, sendo os outros $92,5 \%$ para aplicação na bacia, questionamentos foram feitos. Com isso, houve paralisação dos trabalhos de mobilização no comitê e um malestar nas reuniões pôde ser notado durante a pesquisa de campo. Inclusive, na época, foi feita uma "Carta Aberta" à população e imprensa em geral, uma vez que houve o fechamento da sede administrativa do CBHRV e de ação inicial de possível encerramento das atividades da denominada "Equipe de Mobilização".

A solução, acordada apenas após várias reuniões de verificação das condições administrativas e jurídicas da questão, foi a de se efetuar um edital de seleção de equipe para compor uma equipe de mobilização do comitê. Esse procedimento foi realizado via a determinação legal contida no arcabouço da Lei Federal n ${ }^{\circ} 8.666$ de 1993, também conhecida como a "Lei das Licitações". Consequentemente, o Ato Convocatório 001/2013, pertinente ao Contrato de Gestão n ${ }^{\circ} 02 / \mathrm{IGAM} / 2012$, via a modalidade de "Coleta de Preços", na tipologia "Técnica e Preço" (onde a questão qualitativa e quantitativa da seleção é considerada como fator de classificação), foi publicado, sendo o objeto do contrato a denominação de "Contratação de serviços de educação e mobilização social na bacia hidrográfica do Rio das Velhas". 
Como a própria equipe anterior demonstrou ser a mais qualificada no processo de seleção, via a Fundação de Desenvolvimento da Pesquisa (FUNDEP), foram na prática como que recontratados, como indicaram alguns entrevistados. Assim, a FUNDEP é a responsável pelo referido projeto desde abril de 2013, tendo ocorrido dois termos aditivos ao contrato original de forma a prorrogar o mesmo. Porém agora contaria a equipe em serviço com o respaldo legal que, teoricamente (uma vez que tal prática era também praticada no CBHSF), havia inadequação jurídica anterior. Como exemplo dos resultados alcançados, entre abril de 2013 e fevereiro de 2016, foram entregues 21 diferentes produtos da equipe contratada, tais como: mobilização de população rural para participação nos subcomitês, desenvolvimento de cartilhas sobre educação ambiental, participação social e organização do comitê, eventos culturais no decorrer de toda a bacia, etc.

Por outro lado, a sair da questão puramente legal, interessante notar que a própria legitimidade e utilidade da existência de uma equipe especificamente para mobilizar os subcomitês e o comitê de forma geral foram colocadas em discussão (não necessariamente em xeque). Entretanto, ficou clara a importância dessa equipe de profissionais no sentido de poder possibilitar o gerenciamento de conflitos, latentes ou não, institucionais ou ao nível local da bacia.

Esse evento foi definidor de um posicionamento do comitê em termos de enfrentamento do posicionamento do IGAM mais do que da própria agência, uma vez que tal decisão foi vista como descendente e de pouca abertura inicial. Também foi considerada como uma decisão que atravessou o processo de diálogo institucional que estava em construção no período. Ou como indicou uma liderança entrevista da AGBPV sobre o fato:

"A verdade é comitê e agência precisam ser mais integrados, mais juntos. Sabe...confiança e mobilização é a mesma coisa, quando se perdem tem todo o trabalho de resgate e nem sempre se tem o resgate. E aí tudo o que foi feito antes é perdido e isso tem todo tipo de custo.".

Mais, esse acontecimento lembra as discussões de Ansell e Gash (2007) de que o nível de interdependência existente entre os participantes é fundamental para facilitar ou não que haja colaboração entre eles. Ao mesmo tempo, salienta os autores, medidas de 
apoio institucional e de aumento da confiança mútua são fundamentais, e quando há essa quebra de reciprocidade, conflitos presentes e futuros tendem a emergir.

De fato, como sugere Manikutty (1997), há uma tendência de que projetos participativos tendem a ser mais bem-sucedidos do que aqueles que não são assim constituídos. E mesmo que seja possível a existência de políticas públicas bem implementadas sem a participação comunitária (que demanda uma mobilização anterior para acontecer), quando ela ocorre as possibilidades de êxito aumentam.

Também há o reconhecimento de que a mobilização social do CBHRV é um dos seus diferenciais em relação a outros modelos de organismos de bacia (ou melhor, que teve a mobilização via sociedade civil de forma fundamental). Isso em Minas Gerais e, para alguns, até do Brasil, uma vez que esse comitê tem sido citado de forma corrente como um dos mais organizados do país. Valeriam aqui as observações de uma liderança representante do poder público estadual sobre tal:

"Os conflitos são presentes o tempo todo no Velhas, mas houve uma grave crise institucional no final do ano de 2012. E nisso, o elo mais legítimo, anterior ao comitê o mais prejudicado, que é a mobilização. (...) Com isso a equipe de mobilização foi demitida e readmitida, não é? Mas o bom é que essa crise gerou a oportunidade de falar frente a frente com a AGB e IGAM, porque essa burocracia toda pode engessar o funcionamento da gestão no final das contas ${ }^{57}$."

Por outro lado, toda essa situação de fechamento da sede do comitê e do encerramento, mesmo que parcial, das atividades do Grupo de Mobilização Social relembram de certa maneira os limites para gerenciamento dos comitês. Isso porque eles, de acordo com a Lei Federal $n^{\circ}$ 9.433, os comitês ainda possuem um caráter consultivo e não deliberativo (JONHSSON e LOPES, 2003), o que impõe restrições à sua capacidade de influência no jogo político-administrativo (CUNHA; THEODORO, 2014; EMPINOTTI, 2011).

Finalmente, interessa notar que dentro da atualização do PDRH do Rio das Velhas de 2015 (CBHRV, 2015), em seu Componente 7: Educação Ambiental, Comunicação e Mobilização Social - Programa 7.1 - há um rol de 7 atividades a serem realizadas pelo comitê para aprimorar essas temáticas interna e externamente de forma a evitar futuros

57 Apenas para salientar que, para Ansell e Gash (2007), os diálogos face-a-face são necessários mas não suficientes para se gerar colaboração, que não é apenas negociação entre stakeholders, mas sim a construção de confiança entre eles. E isso é, geralmente, um processo de longo prazo e de monitoramento contínuo.

Programa de Pós-graduação em Saneamento, Meio Ambiente e Recursos Hídricos da UFMG 
conflitos de posicionamento entre as partes interessadas na gestão hídrica ${ }^{58}$. Esse Componente 7 tem como indicadores de desempenho o "Plano de Ação de Educação Ambiental, Comunicação e Mobilização" ser concluído, com recursos advindos do próprio comitê, via cobrança pelo uso dos recursos hídricos ${ }^{59}$

4. Outorgas (Outubro a Dezembro de 2013) $=$ No final do ano de 2013 o CBHRV salientou o crescimento de conflitos relacionados com a questão das outorgas para usos múltiplos dos recursos hídricos. Principalmente na região do denominado "Alto Rio das Velhas", que, de acordo com PROJETO MANUELZÃO (2013(a)):

O Alto rio das Velhas compreende toda a região denominada Quadrilátero Ferrífero, tendo o município de Ouro Preto como o limite ao sul e os municípios de Belo Horizonte, Contagem e Sabará como limite ao norte e ainda uma porção do município de Caeté, tendo a Serra da Piedade como limite leste. Uma região considerada histórica e de fundamental importância para o abastecimento e manutenção da qualidade e quantitativa das águas da Bacia do rio das Velhas.

Dentro dessa região há também a Serra do Gandarela (região de grande diversidade ecológica e área de preservação) e onde conflitos de interesses foram citados. De acordo com os membros do comitê, existiriam diferenças entre a outorga e o seu cadastramento, o que faria com que um fluxo maior de captação ocorresse. Uma situação de grande desconforto para a gestão hídrica da bacia, de acordo com o presidente do comitê à época, o professor da UFMG e médico, Marcus Vinícius Polignano:

\begin{abstract}
"A situação vem se agravando por isso é importante pautar e pontuar as questões que envolvem os problemas que estão sendo levantados. Atualmente podemos perceber pelo panorama geral que as outorgas superam a capacidade de vazão outorgável e quanto mais água tirarmos do alto, pior será para a Bacia.", enfatizou o presidente do CBH Velhas, Marcus Vinícius Polignano, que se posicionou preocupado com a situação do rio das Velhas, que segundo ele, está doente e precisa de cuidados. "O nosso ser é o Velhas. Ele tem que sobreviver. Hoje a água não é suficiente para vazão ambiental e ecológica. É preciso que algo seja feito imediatamente”, ressaltou.
\end{abstract}

\footnotetext{
58 “(...) são compreendidas como um conjunto de ações voltdas a mobilizar e contribuir para um comportamento mais adequado para a preservação dos recursos hídricos através da preparação e disseminação de conhecimentos e informações que permitam à população compreender e refletir sobre a realidade socioambiental, destacadamente sobre os usos e usuários da água, os conflitos e impactos associados a esses usos, a qualidade da água, os papéis dos diferentes atores sociais e os instrumentos da Política Nacional de Recursos Hídricos. Mais que acessar informações claras, a população precisa ampliar progressivamente sua capacidade de interpretar informações socioambientais."

59 A ver, o custo do programa, em sua totalidade, está orçado em R \$ 320.000,00, para valores de 2015, com horizonte de realização de dezesseis anos (2015-2031) como temporalidade máxima.
}

Programa de Pós-graduação em Saneamento, Meio Ambiente e Recursos Hídricos da UFMG 
(...) "Não podemos fugir da verdade", declarou Polignano ao afirmar que o Plano Diretor, deverá contar com diretrizes e critérios definidos. "No plano temos que trabalhar a verdade, mas de forma factivel, baseado em dados técnicos". Para ele, é fundamental solicitar a questão do conflito também nesse processo."- PROJETO MANUELZÃO (2013(a))

Consequentemente, e por ser uma discussão muito crescente no comitê, foi decidida uma comissão para analisar o assunto na última reunião do ano de 2013, assim explicada também pelo presidente do CBHRV:

"O problema não se restringe ao Alto e não é apenas mudando critérios e normas que resolveremos os problemas. Temos um problema muito maior", avalia Polignano ao argumentar que é hora de esclarecer os fatos. "O Comitê não pode ser desova dos problemas da bacia se ele não tem a capacidade de decisão. Temos que ir para a luta", desabafou. (...) os debates esse ano foram importantes. Temos conflitos, mas sempre nos pautamos pela decisão de todos. $O$ ano que vêm teremos muitas decisões a tomar, mas faremos tudo o possivel para salvar nossas águas e nossos rios", salientou o presidente." - PROJETO MANUELZÃO (2013(b)).

Foram realizados encaminhamentos ao IGAM para que os processos de outorga fossem mais criteriosos em termos de sua liberação para a região do Alto Rio das Velhas, assim como para a bacia em geral. Infelizmente, como já citado em JEM (2015) e CBHRV (2015(b)), essa problemática permanece e tanto os conflitos de interesses quanto as reuniões de negociação por ações consensuais continuam. Isso significa que a responsabilidade dos órgãos gestores sobre a matéria só tende a crescer, uma vez que o número de outorgas requeridas para os diversos usos não parece diminuir e a capacidade de organização e monitoramento das mesmas é muito criticada.

5. Crise hídrica (Agosto de 2015): Como já anteriormente descrita, a crise hídrica pela qual o país passou a partir do ano de 2012 fez com que diversas ações ao redor do país acontecessem ao nível institucional e administrativo (ANA, 2015(a); IGAM, 2015(b)). Em Minas Gerais esses fenômenos naturais de seca também foram observados e no Rio das Velhas tal situação foi recorrente. Ou como uma liderança entrevistada da AGBPV indicou em janeiro de 2014:

“(...) o regime dos rios é que tem se modificados e não somente o volume em si. Há perda de áreas de recargas em vários locais e o escoamento de arraste é muito maior, com picos muito maiores. Quer dizer, com secas e cheias muito mais acentuadas. A vazão tende a ser constante, mas as formas de amortecimento têm sido diferenciadas.

Programa de Pós-graduação em Saneamento, Meio Ambiente e Recursos Hídricos da UFMG 
Consequentemente, existem mais sedimentos nas correntes. E tudo isso faz com que as ações hoje sejam mais para melhorar o quali-quant das águas e para proteção de áreas de recarga e saneamento."

Essa visão de alterações climáticas também foi citada pelo representante do poder municipal de Belo Horizonte, entrevistado ao final do ano de 2013, sendo que para o qual “(...) o ciclo da água dos rios hoje e com picos, ou seja, na maior nas enchentes e menor nas secas. E esse comportamento eu te digo hoje que se dá em toda a bacia.". A realidade é que o IGAM foi e tem sido muito solicitado a manter um maior controle sobre os recursos hídricos desde que a situação dos mesmos passou a ser considerada como de escassez pelo próprio CBHRV (CBHRV, 2015(c)).

Como exemplo, em agosto de 2015, alguns representantes dos organismos de bacia do Rio das Velhas se reuniram para resolver o conflito da sub-bacia do Rio Ribeiro Bonito, na região rural do município de Caeté, pertencente à $\mathrm{RMBH}$. Os principais problemas citados foram falta de hidrômetros, tecnologias de irrigação ultrapassadas e a constante falta de fiscalização.

Como propostas desenvolvidas a partir das negociações entre os atores sociais interessados, foram feitas algumas de curto prazo, dados os conflitos crescentes:

1. Medição da vazão: será realizada pelo SAAE com a finalidade de saber qual é o nível criticidade na bacia e então dimensionar o tamanho do problema de conflito. A medição será realizada uma vez por semana com apoio da equipe do comitê. 2. Fim da pressão nos pequenos produtores: o SAAE não poderá pressionar os produtores rurais, porque a empresa não tem poder de polícia para realizar manobras como o lacre de bombas, por exemplo. É papel do IGAM atuar com restrições caso seja encontrada alguma conduta irregular.

3. Uso insignificante de água não entra na outorga coletiva: produtores que não fazem usos elevados de água, ou seja, o chamado uso irrelevante, terão o direito ao uso da água independente das questões restritivas da outorga coletiva. 4. Estado de restrição: de acordo com a medição do volume de vazão, a região entrará em estado de restrição, tendo de reduzir o uso da água de acordo com a realidade da oferta.

5. Outorga sazonal: trabalhar com diferentes permissões de captação, de acordo com o período de chuva e seca.

6. Regularização das outorgas pelo IGAM.

7. Fiscalização dos usuários pelo IGAM.

8. Fim das outorgas: por enquanto não será permitida a realização de nenhuma no Ribeiro Bonito para não aumentar a situação de conflito.

6. Desastre ambiental (Novembro de 2015): A temática da atuação das mineradoras na bacia hidrográfica do Rio das Velhas quase sempre foi colocada em questão nas 70

Programa de Pós-graduação em Saneamento, Meio Ambiente e Recursos Hídricos da UFMG 
atas de reunião pesquisadas. Na maioria dos casos foram levantadas suspeitas pela sociedade civil e eventualmente por poderes públicos estaduais ou municipais em relação ao tipo de captação e utilização dos recursos hídricos para o setor mineral. Como exemplo é possível citar os conflitos gerados pelo desastre do rompimento de uma barragem na cidade mineira de Mariana, em 24 de novembro de 2015. Apesar de ser estar localizada na bacia hidrográfica do Rio Doce, esse episódio, considerado por muitos como o de maior impacto ambiental na história brasileira de que se tem notícia, foi considerado determinante para um posicionamento mais rígido do CBHRV sobre o tema mineração.

Como pode ser verificado na minuta da ata da $87^{\mathrm{a}}$ reunião do CBHRV, em 16 de dezembro de 2015, pelas falas citadas de vários membros do comitê, que expressam claramente preocupações sobre os níveis de influência que a atividade mineradora pode ter nas atividades sociais e econômicas:

Marcus Vinícius Polignano sinaliza que o CBH Rio das Velhas se posicionou publicamente contrário à calamidade ocasionada pelo desastre e também por suas consequências que representam prejuízos além de questões econômicas e sociais, como também a perda da identidade social. Considera ser um dano imensurável, pois ele ocorreu de forma sistêmica, se estendendo por $500 \mathrm{~km}$ de rio e atingindo $40 \mathrm{~km}$ mar adentro. (...) Expõe a necessidade de que o CBH Rio das Velhas promova discussões acerca do ocorrido e que a atividade de mineração seja revista enquanto projeto e processo, pois considera inadmissível, com a existência de tecnologia, de conhecimento e de responsabilidade ambiental (...). O Sr. Eduardo Nascimento FETAEMG considera um desrespeito por parte da empresa Samarco de não participar dos debates públicos, informa que a empresa já foi convidada quatro vezes a comparecer na Assembleia e não compareceu, como se ela não tivesse a obrigação de prestar esclarecimentos em espaços públicos.(...) O Sr. Deusdedite Aguiar - Prefeitura Municipal de Santa Luzia, explica que há registros de que o nosso minério anteriormente continha alto teor ferrífero, mas com o crescimento produtivo, fomos utilizando o minério rico, o que promoveu a necessidade de aproveitamento de outros tipos de minérios. Para ele, tudo parece ser uma questão econômica de concorrência e internacionalização de commodities de minério(...). Considera necessário compreendermos os aspectos econômicos da atividade de mineração em Minas Gerais, em relação à dimensão da economia do Estado e sobre a estratégia do Estado em conviver com mineração apesar do elevado risco de atividade.

Isso sinaliza que a desconfiança em relação ao setor minerário continua a existir em larga escala e que as negociações com esse setor são fundamentais atualmente. Em uma análise das políticas públicas com o setor mineral e utilização de bens naturais, é possível indicar que são conflitantes há várias décadas e que apenas a regularização e normatização do 
setor não têm mostrado a eficiência prometida (DULCI, 1999). Tanto que, de acordo com uma liderança representante do poder público estadual entrevistada,

"O fato é que o poder público municipal e o estadual ficam mesmo é no meio entre a sociedade civil e os usuários, os setores industriais, principalmente grandes empresas e mineração. E aí eles (poderes públicos) têm de atuar como mediadores, o que nem sempre dão conta."

Finalmente, em 16 de dezembro de 2015 foi publicada a "Moção - Rompimento de Barragem de Rejeitos", uma das únicas 3 moções realizadas pelo CBHRV em mais de 15 anos de existência ${ }^{60}$. Foi a uma forma de posicionamento do comitê frente ao ocorrido e também como indicação de apoio ao CBH do Rio Doce pelo evento ocorrido.

7. Conflitos relativos ao conhecimento técnico científico: Existem também conflitos que são vinculados com as diferentes perspectivas e formas de atuação oriundas dos setores que detém o chamado "conhecimento técnico científico" (CTC), visto em ABERS (2010). Esses segmentos incluem indivíduos representantes de áreas de conhecimentos específicos e variados que, em uma situação de determinação de normas legais, técnicas ou administrativas, tendem a ser mais considerados dentro das discussões do os setores da sociedade civil, por exemplo.

Isso acontece porque os técnicos possuem o domínio do caráter técnico que é considerado fundamental em sistemas de gestão que, mesmo sendo participativos, possuem sua essência no sistema burocrático da tomada de decisões. De forma geral no CBHRV, esses momentos de eventuais conflitos são apontados mais nos processos de debates nas Câmaras Técnicas (CTs) e, consequentemente, na apresentação de indicações de aceitação ou não das deliberações tomadas nas plenárias gerais do comitê.

Apesar de serem constantes, é possível considerar que são de pequena escala e têm sido contornados via processos de negociação, tais como o de acontecer segundos ou terceiros debates entre os membros, reapresentação em plenária após ajustes. Mesmo com a consideração de que o CTC possui possíveis benefícios para o aprimoramento

As outras duas foram: 1) em 22 de agosto de 2014 (contra a proposta de Lei 5.245/2014, que altera a lei número 15.082 de 2004, que dispões sobre os rios de preservação permanente); 2) em 19 de dezembro de 2014 (contra o Projeto de Lei 3436/12, que visava alterar a redução da área da Estação Ecológica do Cercadinho, localizado em Belo Horizonte).

Programa de Pós-graduação em Saneamento, Meio Ambiente e Recursos Hídricos da UFMG 
da gestão hídrica, por outro lado podem criar barreiras ao amplo acompanhamento público:

Em suma, estudos apontam que, no caso específico da gestão de recursos hídricos, o uso de CTC pode efetivamente facilitar e promover a escolha de alternativas mais robustas e sustentáveis. Contudo, ao mesmo tempo ele é potencialmente capaz de desestimular ou dificultar a participação democrática no processo descentralizado de gestão, caso o acesso e o entendimento do CTC ocorra de modo desigual. (ABERS, 2010, p. 53).

\subsubsection{O que esses conflitos sinalizam}

O primeiro ponto a se reconhecer é que nem todos os tipos de conflitos existentes na gestão das políticas públicas de recursos hídricos na bacia hidrográfica do Rio das Velhas foram aqui identificados. E tal fato há um fundo de razão muito citado nas entrevistas e trabalho de campo também, principalmente nos bastidores das reuniões plenárias. É que, como descrito por um ex-presidente do CBHRV,

“(...) existem conflitos expressos e outros que são reprimidos no Velhas. E,
claro...existem conflitos que, algumas vezes, o próprio comitê não tem maturidade
para realizar essas discussões, o que passa muito pela existência de uma agência de
bacia para se poder fazer isso, quando possível. Mas não há uma AGB técnica, pois
ainda não tem estrutura para isso, que é pegar uma demanda técnica e torná-la
política pública.

O que significa que a compreensão de todos os conflitos existentes ainda não pode ser linear, pois vários dos embates acontecem, inclusive, de forma paralela e demandam capacidades de decisões específicas. Tanto que existem agora as Câmaras Técnicas para tentar diminuir os espaços para os conflitos e ampliá-los para os debates com procedimentos consultivos (mas nunca deliberativos, porque quem delibera é a plenária do comitê). Mas somente elas não são capazes de identificar ou externar todas as várias faces de conflitos que realmente acontecem em todos os locais da bacia hidrográfica, quando considerada a perspectiva da existência do que do que disse um dos representantes do setor dos usuários entrevistado é que “(...) existem conflitos expressos e outros que são reprimidos. Ou...as pessoas não expressam. Ou não querem expressar.".

Fato é que, de acordo com os conflitos mais claramente identificados, esses podem ser considerados conflitos em que o CBHRV teve de aprender a modificar suas formas de gestão na direção de conseguir ser mais participação de seus membros. Principalmente, os conflitos

Programa de Pós-graduação em Saneamento, Meio Ambiente e Recursos Hídricos da UFMG 
indicaram ao comitê a demanda de se posicionar cada vez mais na direção de autoafirmação perante os outros organismos de bacia (fosse a AGBPV, PBH, IGAM ou mesmo ANA) como um local legítimo para a consulta e deliberação sobre recursos hídricos. Com isso, no longo prazo de seus mais de 15 anos de existência, o comitê pôde amadurecer institucionalmente sobre a aplicação dos instrumentos de gestão previstos na legislação e, fundamentalmente, pôde incluir mais interação e capacitação entre seus membros. E isso aconteceu tanto via a inclusão de projetos, CTs ou eventos, todos direcionados para a superação de conflitos de suas partes interessadas. Ou, como indicou um dos representantes da AGBPV entrevistado, “(...) há um amadurecimento dos próprios membros dos comitês. Provavelmente o próprio Velhas deve ser cada vez mais consolidado quanto mais sua atuação acontecer."

\subsection{A história política da região}

A região pertencente ao Rio das Velhas só pode ser verdadeiramente conhecida a partir de sua história social e política suas interações. Por estar localizada em uma larga e longitudinal extensão territorial que alcança algumas regiões do Estado de Minas Gerais, é uma bacia de perfil diferenciado no tempo e espaço. Sua ocupação se originou a partir da segunda metade do século XVII (BURTON, 1977; JOHNSSON e LOPES, 2003), com um perfil que foi construído primeiramente a partir do ciclo do ouro até o século XVIII, quando houve o seu declínio.

Simultaneamente houve o incremento dos setores de agricultura e pecuária, com destaque para a produção cafeeira do século XIX e leiteira do início do século XX (LISBOA, 2012). O ressurgimento da exploração mineral, que deu nome ao estado "das minas gerais", ocorreu apenas na primeira metade do século XX, principalmente a partir do ferro, cobre, magnesita, ouro, dentre outros.

Esse caráter de várias culturas e setores de produção também pode ser encontrado no campo político na medida em que, tal como indica uma liderança “(...) os mineiros têm caráter de conciliação, negociação, gostam de conversar com todo mundo, mas pouco”. Isso significa que a cultura política, considerada por alguns autores como fundamentais para ações de mobilização e participação sociais bem-sucedidas (ABERS e KECK, 2004; FRÉROT, 2009; CUNHA; THEODORO, 2014), foi aqui construída pela agregação e negociação (JOHNSSON, LOPES, 2003; LISBOA, 2012; GIL, 2008). E apesar da maior influência de sua região metropolitana e da capital do estado (GARSON, 2009), “A vida política mineira é

Programa de Pós-graduação em Saneamento, Meio Ambiente e Recursos Hídricos da UFMG 
bastante federativa, ou seja, Belo Horizonte não centraliza a política estadual." (JOHNSSON; LOPES, 2003).

De fato, o estado de Minas Gerais é local de origem de vários presidentes da república e histórico de possuir tendências políticas diversas, tendo o estado sido gerenciado por vários partidos. Em termos estaduais, a partir da redemocratização do país em 1985, o estado teve tantos governadores de tendência liberal como também trabalhista. Foram todos eles efetivados via processos eletivos que foram iniciados nas eleições gerais de 1986 e que iniciaram um novo perfil dos políticos modernos brasileiros e suas relações com a sociedade civil e o setor privado (ALMEIDA, 2007). Relações que se assemelham às ponderações de RUA e ROMANINI (2013) quando indicam que:

Na definição clássica de Max WEBER (1970), os políticos modernos são "empresários do voto". Em princípio, portanto, são atores cuja posição resulta da conquista de mandatos eletivos. Por essa razão, sua atuação nas políticas públicas é condicionada principalmente pelo cálculo eleitoral: eles avaliam como suas decisões poderão lhes render votos ou apoios para conquistar eleitores. No entanto, variando conforme cada sistema político, também pesa em sua atuação o pertencimento a partidos políticos, ou seja: seu próprio empoderamento dentro dessas organizações que disputam o preenchimento de cargos públicos. São exemplos: os parlamentares, governadores, prefeitos, membros eleitos do Executivo federal.

Já em um recorte delimitado ao período de implantação da Lei das Águas em 1997 e da oficialização do CBHRV em 1998, até o ano de 2013, período de análise da pesquisa, foram eleitos (ou assumiram por serem vice) como governadores 4 políticos de 2 diferentes partidos (TSE, 2015), sendo o Partido da Social Democracia Brasileira (PSDB) eleito por 3 vezes e o Partido do Movimento Democrático Brasileiro (PMDB) uma vez no período.

Cabe ressaltar que esses partidos encabeçaram alianças políticas junto a vários partidos menores e que dos governadores, dois deles, Aécio Neves e Antônio Anastasia, exerceram o cargo por mais de um mandato:

1) Eduardo Azeredo, engenheiro mecânico, Partido da Social Democracia Brasileira, PSDB, entre $1^{\circ}$ janeiro de 1995 a $1^{\circ}$ de janeiro de 1999 ;

2) Itamar Franco, engenheiro civil, Partido do Movimento Democrático Brasileiro, PMDB, entre $1^{\circ}$ janeiro de 1999 a $1^{\circ}$ de janeiro de 2003; 
3) Aécio Neves, economista, Partido da Social Democracia Brasileira, PSDB, entre $1^{\circ}$ janeiro de 2003 a $1^{\circ}$ de janeiro de 2007 e de entre $1^{\circ}$ janeiro de 2007 a 31 de março de 2010;

4) Antônio Anastasia, advogado, Partido da Social Democracia Brasileira, PSDB, entre 31 de março de 2010 a $1^{\circ}$ de janeiro de 2011 (assumindo por ser vice-governador) e entre $1^{\circ}$ de janeiro de 2011 a 4 de abril de 2014 (assumindo por eleição).

Como é identificado, o período de implantação das legislações mais pertinentes sobre recursos hídricos em âmbito nacional e estadual se iniciaram no período de governo de Eduardo Azeredo, 9.433/97, e Itamar Franco, 13.199/99, respectivamente. Já o período de formação do CBHRV (1998) se encontra ligado ao mandato de Eduardo Azeredo, porém sua efetiva aplicação se deu durante o primeiro governo de Aécio Neves, principalmente (2003-2007) PROJETO MANUELZÃO (2012).

Pois foi nesse primeiro mandato que ele garantiu a inclusão de políticas públicas de recursos hídricas ligadas ao Rio das Velhas, sobretudo a partir da influência da liderança exercida pelo Projeto Manuelzão na época. Essa influência se deu tanto pela presença de liderança histórica presente na figura de Apolo Heringer Lisboa, da Faculdade de Medicina da Universidade Federal de Minas Gerais (UFMG), como pela proximidade de diálogo deste e do Projeto Manuelzão como um todo junto ao governo de Aécio Neves e de seu vice-governador, Antônio Anastasia, ambos do PSDB.

Esse perfil de tendência tradicionalista e que ao mesmo tempo incorporador de políticas regionais tem seguido a lógica das articulações e coligações políticas de governo em Minas Gerais. Para demonstrar, o panorama do contexto político das prefeituras indica que existem as mais variadas coligações políticas possíveis para o exercício do mandato de 2012-2016. A título de exemplo, o prefeito eleito de Belo Horizonte, Márcio Lacerda, administrador, do PSB (Partido Socialista Brasileiro), pertence a uma coligação de mais de 18 partidos políticos no total (TSE, 2015).

Ao mesmo tempo, esse formato articulador é também observado principalmente a partir da redemocratização do país, e de forma crescente na maioria dos estados da federação (ABERS, 2010; JOHNSSON E LOPES, 2003). Do mesmo jeito, Minas Gerais também se caracteriza por ter uma economia de indústrias e serviços muito dinâmica e bastante variada, com foco 
em várias áreas de atuação, de mineração a tecnologia de ponta (DULCI, 1999; FEAM, 1998).

E isso se revela no fato de que, ainda que não haja uma identidade única por toda a bacia hidrográfica do Rio das Velhas, por outro lado permite que haja identidades regionais em seu vasto território de 51 municípios. E isso foi proposto a ser reproduzido nas subdivisões administrativas apresentadas durante o tempo de existência do CBHRV (THEODORO, 2002; CUNHA; THEODORO, 2014; IGAM, 2014; CAMARGOS, 2005 e 2008). Essa diversidade regional acabou por caracterizar também a forma como o próprio CBHRV foi se criando, uma vez que foi construindo redes de colaboração de micro para macro abrangência via seu principal ator social e político inicial, o Projeto Manuelzão.

Esse projeto foi o responsável por unir vários dos interessados na gestão hídrica em um grupo próprio de discussões (tal como se deu também no Rio Itajaí, em Santa Catarina) e com metas concretas de ação, ao invés das políticas tradicionais na área, dispersivas: “A experiência do Rio das Velhas se moveu na direção oposta, começando pela organização de dúzias de pequenos grupos, os Comitês Manuelzão, e conectando-os em conjunto sob um mesmo guarda-chuva.” (ABERS, 2007, p. 1459).

Em termos políticos e institucionais na atualidade, entretanto, a estrutura dos serviços ambientais tem sido cada vez mais questionada pelos atores sociais participantes (atuais e antigos) do CBHRV. Para algumas lideranças, “(...) há um sucateamento da gestão, porque Minas Gerais perdeu muito de sua estrutura de gestão, de seu pessoal e tudo o mais nos últimos anos.".

Tais relatos, contrapostos às documentações e trabalho de campo identificaram problemas institucionais citados principalmente a partir do segundo mandato (2004-2008) do governador Aécio Neves, do PSDB. Ele conseguiu polarizar sua agenda pública pelo cunho supostamente desenvolvimentista no estado mineiro pautado em políticas econômicas consideradas neoliberais e de forte relação com os setores privados.

Simultaneamente, porém, fez uma aproximação com os setores da sociedade civil vinculados com a gestão ambiental e hídrica no sentido de incorporar algumas das demandas destes, destacadamente a "Meta 2010”. A meta foi a proposta da recuperação da navegabilidade e da volta dos peixes ao Rio das Velhas como sinal de recuperação socioambiental da região. 
O tempo, no entanto, demonstrou que o apoio dado à gestão ambiental e hídrica foi menos do que o esperado, pois, segundo uma liderança, “(...) as opções e prioridades do governo estadual e municipal, de Belo Horizonte, para o meio ambiente, mudaram ou nunca foram essas na verdade, sabe?”. Um dos exemplos mais citados durante a pesquisa foram as ações relativas às intervenções na infraestrutura urbana de Belo Horizonte e sua região metropolitana, que possui uma rede de bacias hidrográficas variadas tal como pode ser visto na Figura 5.9:

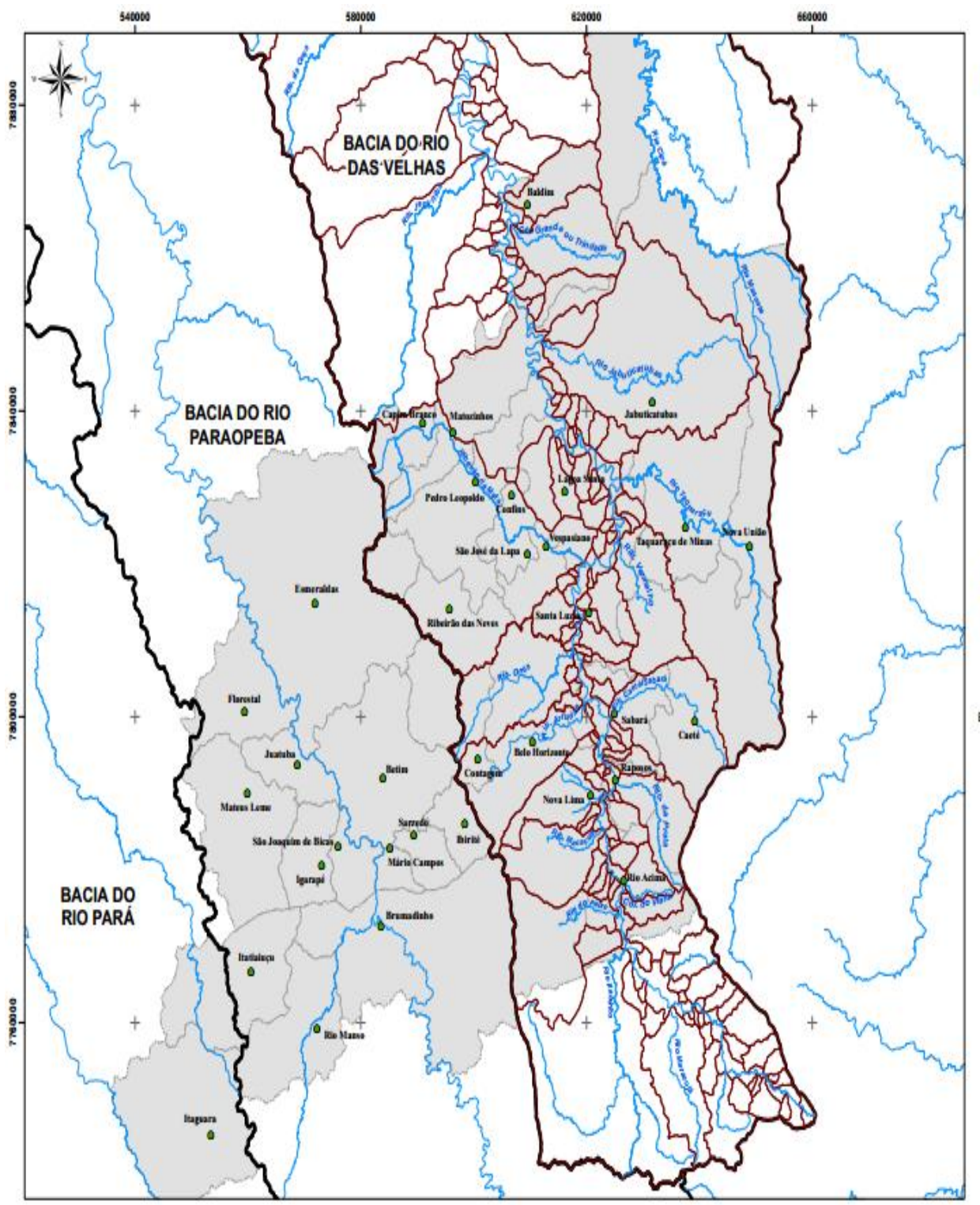

BACIAS HIDROGRÁFICAS DA REGIÄO METROPOLITANA DE BELO HORIZONTE
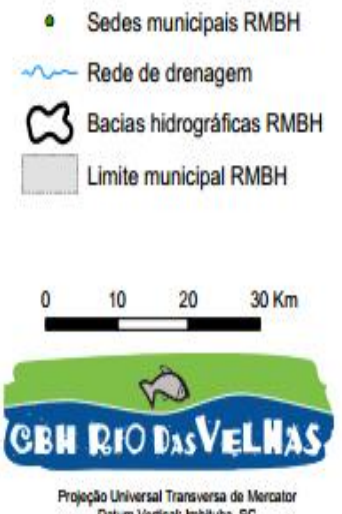
Datum Verioal: mbluba, $8 \mathrm{C}$

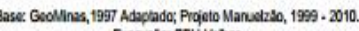
Elizorectia: Dariel Caradimento

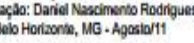

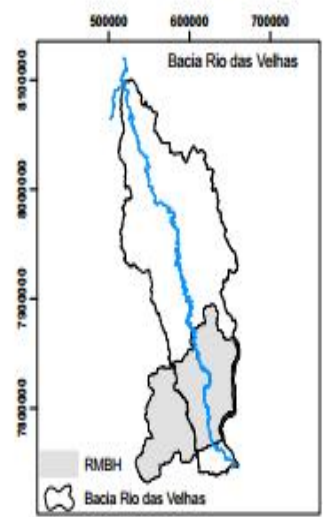

Figura 5.9: Bacias hidrográficas da Região Metropolitana de Belo Horizonte Fonte: CBHRV, 2015(a) 
Especificamente, foram canalizados diversos trechos do Ribeirão Arrudas (dentre outros), afluente do Rio das Velhas, inclusive na região central da cidade, para a criação do que foi denominado como "Boulevard Arrudas". Esse foi um projeto de intervenção urbana com forte impacto de controle dos cursos de água para possibilitar a suposta revitalização de vias de alta densidade de tráfego na área central da metrópole. Tal ação foi considerada na contramão das propostas em desenvolvimento sustentável existentes na capital, destacadamente o Programa de Recuperação Ambiental de Belo Horizonte (DRENURBS) - BONTEMPO et al., 2012.

Este programa tem todo um histórico em relação às tentativas da gestão institucional local em melhorar e controlar os recursos hídricos da capital mineira, com a reversão dos seus córregos não canalizados. É uma proposta, distinta da utilizada tradicionalmente pelos governos, o que faz dela alternativa para questões de drenagem urbana convencionais. De acordo com PBH (2013),

O Programa DRENURBS / NASCENTES foi lançado pelo Município de Belo Horizonte, por meio da extinta Secretaria Municipal de Política Urbana. Elaborado para ser implementado em fases sucessivas, o DRENURBS visa promover a despoluição dos cursos d'água, a redução dos riscos de inundação, o controle da produção de sedimentos e a integração dos recursos hídricos naturais ao cenário urbano. A Prefeitura de Belo Horizonte, ao criar o Programa DRENURBS, trouxe como inovação a proposta de inclusão dos cursos d'água na paisagem urbana, evitando-se as tradicionais canalizações. Há, também, o desafio da despoluição de suas águas, o que leva à busca de projetos que possam integrar serviços urbanos como a coleta de lixo e de esgotos ao serviço de drenagem das águas pluviais. Portanto, a área de trabalho deixa de ser apenas o leito do córrego para abranger toda sua bacia de drenagem.

Essas formas antagônicas de se lidar com os recursos hídricos na bacia hidrográfica do Rio das Velhas demonstram como integrar a gestão municipal, metropolitana e regional é um tema complexo no país (FREY, 2012). São visões de mundo (propostas convencionais e alternativas) que poderiam coabitar o mesmo espaço e serem discutidas conjuntamente. Mas, na realidade, elas são vistas como antagônicas em termos da aplicação técnica versus a concepção mais socioambiental, como salienta Moreira $(2013$, p.) salienta em todo o seu trabalho:

Portanto, é preciso perceber que todas essas abordagens, tanto no Brasil quanto nos demais países, com raras exceções, têm cunho predominantemente técnico assente na ideia setorizada do planejamento urbano, da administração pública e da ciência, trazendo controvérsias e fortes questionamentos em se analisando o desenho de cada processo. É possível que a maior crítica esteja ligada às formas de intervenção do 
espaço que abordam a participação popular de forma superficial, raramente considerando profundamente a gestão participativa no planejamento e na apropriação de tais espaços transformados.

Na verdade, existem críticas gerais em relação às políticas públicas de recursos hídricos não só na bacia hidrográfica do Rio das Velhas como também na bacia hidrográfica do Rio Pará, que é limítrofe e semelhante em algumas demandas (por melhoras na quantidade/qualidade de água, por exemplo) e origem de formação (com presença de lideranças reconhecidas como fortes em termos técnicos e sociais (JOHNSSON e LOPES, 2003). Fato é que após 12 anos de governo consecutivos da coligação liderada pelo PSDB no estado de Minas Gerais, em 2014 foi eleita a coligação de oposição, liderada pelo Partido dos Trabalhadores (PT). O governador eleito foi o ex-prefeito de Belo Horizonte (2005-2008) e ex-ministro do Desenvolvimento, Indústria e Comércio Exterior (2011-2014) do primeiro mandato da presidente Dilma Roussef, o economista Fernando Pimentel (com mesma formação de Aécio Neves). Foi a primeira vez que o PT assumiu o governo mineiro como líder da coligação partidária da qual fez parte, com um discurso de investimentos consistentes na área de infraestrutura estadual, para o período 2015-2018.

Esse período, entretanto, não é abarcado na presente pesquisa (cujo escopo se dá entre 19982012), o que impossibilita uma análise comparativa entre as linhas de atuação dos planos de governo e ações das duas coligações (PT x PSDB). Tidas como adversárias em pleitos anteriores para o setor de recursos hídricos, apenas a partir de 2019, que tal exercício será passível de ser realizado. Porém, adiante é realizada uma série de identificações sobre de quais formas as políticas públicas do estado mineiro e do CBHRV em particulares, ocorreram.

Todavia, tal análise longitudinal pôde ser realizada, por exemplo, no caso do CBH-Santa Maria, no estado do Rio Grande do Sul, ou no caso do Consórcio Intermunicipal para o Desenvolvimento Sustentável da Bacia do Rio Taquari (COINTA), nos estados de Mato Grosso e Mato Grosso do Sul, ambos no final da década de 1990 e início dos anos 2000. Nesses locais as mudanças político-administrativas estaduais modificaram as perspectivas de ação dos órgãos ambientais e geraram novas formas de interação entre os atores institucionais envolvidos (JOHNSSON E LOPES, 2003; ABERS, 2010). Em essência, a história política da região do Rio das Velhas é mais caracterizada por laços de colaboração municipal interregional. Um exemplo dessa interação é a RMBH, formada por 34 municípios e que possui uma crescente experiência na criação e gestão de espaços de interação social e política em sua área de abrangência.

Programa de Pós-graduação em Saneamento, Meio Ambiente e Recursos Hídricos da UFMG 
Essa região possui um conjunto de organismos de gestão usualmente pouco vistos em áreas urbanas, tais como: Conselho Deliberativo de Desenvolvimento Metropolitano; Agência de Desenvolvimento Metropolitano; Associação dos Municípios da Região Metropolitana de Belo Horizonte (GRANBEL); Grupo de Governança Metropolitana; Associação dos Municípios da Região Metropolitana de Belo Horizonte; Assembleia Metropolitana e de um Fórum Metropolitano (FREY, 2012; PBH, 2015; AMDBH, 2016; SEDRU, 2011). Especificamente em relação ao gerenciamento hídrico é preciso analisar que há relação complexa que se dá na região, sendo que o CBHRV não pode ser compreendido apenas em si mesmo, mas como parte de um sistema maior de interferências, como pode ser visualizado comparativamente no Quadro 5.3 adiante. Nele fica mais identificada que não são somente os municípios da bacia hidrográfica do Rio das Velhas que são impactos na gestão desse rio.

Ao contrário, na região do comitê há também os municípios da RMBH e também os municípios do já citado "colar metropolitano", o que totaliza um conjunto de 75 municípios que sofrem diferentes influências das políticas públicas que vão sendo realizadas, dadas as suas possíveis interfaces (SEDRU, 2011; OLIVEIRA, 2006; REZENDE e HELLER, 2008; MOREIRA, 2013). De acordo com liderança representante do segmento municipal e com experiência na gestão metropolitana de recursos hídricos, a consideração do colar metropolitano é importante porque

(...) o colar metropolitano revela na verdade que muitos mais municípios do que pensamos são afetados pela metropolização. Belo Horizonte está cada vez maior, mais complexa de gerir. Tem muitos problemas. E os municípios próximos já são muito afetados. Agora os mais distantes também têm muitos problemas. Veja bem...conseguir uma água de qualidade nessa região é muito difícil, mas no longo prazo...pode ser...é possível...Vai depender das interações entres os órgãos, mas pode demorar.

Como pode ser identificado no Quadro 5.3, há interações entre os municípios que participam do CBHRV, do CMBH e da RMBH, sendo que, além dos 51 que participam do CBHRV, conta-se também com as 34 cidades da Região Metropolitana de Belo Horizonte, as 16 cidades do Colar Metropolitano ${ }^{61}(\mathrm{RMBH}, 2016)$. Ao ser desconsiderada a repetição dos municípios que participam em mais de uma dessas classificações, tem-se o total de 75 cidades participantes.

$61 \quad$ O Colar Metropolitano tem recebido propostas para a incorporação de novos municípios em sua formação, tanto em relação aos impactos advindos das atividades produtivas de Belo Horizonte, como também por conta das possibilidades políticas de tal adesão.

Programa de Pós-graduação em Saneamento, Meio Ambiente e Recursos Hídricos da UFMG 
Quadro 5.3: Comparação entre as vinculações municipais e o CBHRV, RMBH e CMBH

\begin{tabular}{|c|c|c|c|c|c|}
\hline & $\begin{array}{c}\text { CIDADES } \\
\text { CBHRV }\end{array}$ & $\begin{array}{c}\text { CIDADES } \\
\text { RMBH }\end{array}$ & $\begin{array}{c}\text { CIDADES } \\
\text { CBHRV e RMBH }\end{array}$ & $\begin{array}{c}\text { CIDADES } \\
\text { CMBH }\end{array}$ & $\begin{array}{c}\text { CIDADES } \\
\text { CBHRV e CMBH } \\
\end{array}$ \\
\hline 1. & Araçaí & Baldim & Baldim & Barão de Cocais & Funilândia \\
\hline 2. & Augusto de Lima & Belo Horizonte & Belo Horizonte & Belo Vale & Itabirito \\
\hline 3. & Baldim & Betim & Caeté & Bom Jesus do Amparo & Prudente de Morais \\
\hline 4. & Belo Horizonte & Brumadinho & Capim Branco & Bonfim & Sete Lagoas \\
\hline 5. & Buenópolis & Caeté & Confins & Fortuna de Minas & \\
\hline 6. & Caeté & Capim Branco & Contagem & Funilândia & \\
\hline 7. & Capim Branco & Confins & Esmeraldas & Inhaúma & \\
\hline 8. & Conceição do Mato Dentro & Contagem & Jaboticatubas & Itabirito & \\
\hline 9. & Confins & Esmeraldas & Lagoa Santa & Itaúna & \\
\hline 10. & Congonhas do Norte & Florestal & Matozinhos & Moeda & \\
\hline 11. & Contagem & Ibirité & Nova Lima & Pará de Minas & \\
\hline 12. & Cordisburgo & Igarapé & Nova União & Prudente de Morais & \\
\hline 13. & Corinto & Itaguara & Pedro Leopoldo & Santa Bárbara & \\
\hline 14. & Curvelo & Itatiaiuçu & Raposos & S.Gonçalo R. Abaixo & \\
\hline 15. & Datas & Jaboticatubas & Ribeirão das Neves & S.José da Varginha & \\
\hline 16. & Diamantina & Juatuba & Rio Acima & Sete Lagoas & \\
\hline 17. & Esmeraldas & Lagoa Santa & Sabará & & \\
\hline 18. & Funilândia & Mário Campos & Santa Luzia & & \\
\hline 19. & Gouveia & Mateus Leme & Taquaraçu de Minas & & \\
\hline 20. & Inimutaba & Matozinhos & Vespasiano & & \\
\hline 21. & Itabirito & Nova Lima & & & \\
\hline 22. & Jaboticatubas & Nova União & & & \\
\hline 23. & Jequitibá & Pedro Leopoldo & & & \\
\hline 24. & Joaquim Felício & Raposos & & & \\
\hline 25. & Lagoa Santa & Ribeirão das Neves & & & \\
\hline 26. & Lassance & Rio Acima & & & \\
\hline 27. & Matozinhos & Rio Manso & & & \\
\hline 28. & Monjolos & Sabará & & & \\
\hline 29. & Morro da Garça & Santa Luzia & & & \\
\hline 30. & Nova Lima & São Joaquim de Bicas & & & \\
\hline 31. & Nova União & São José da Lapa & & & \\
\hline 32. & Ouro Preto & Sarzedo & & & \\
\hline 33. & Paraopeba & Taquaraçu de Minas & & & \\
\hline 34. & Pedro Leopoldo & Vespasiano & & & \\
\hline 35. & Pirapora & & & & \\
\hline 36. & Presidente Juscelino & & & & \\
\hline 37. & Presidente Kubitschek & & & & \\
\hline 38. & Prudente de Morais & & & & \\
\hline 39. & Raposos & & & & \\
\hline 40. & Ribeirão das Neves & & & & \\
\hline 41. & Rio Acima & & & & \\
\hline 42. & Sabará & & & & \\
\hline 43. & Santa Luzia & & & & \\
\hline 44. & Santana de Pirapama & & & & \\
\hline 45. & Santana do Riacho & & & & \\
\hline 46. & Santo Hipólito & & & & \\
\hline 47. & São José da Lapa & & & & \\
\hline 48. & Sete Lagoas & & & & \\
\hline 49. & Taquaraçu de Minas & & & & \\
\hline 50. & Várzea da Palma & & & & \\
\hline 51. & Vespasiano & & & & \\
\hline Total & 51 Municípios & 34 Municípios & 20 Municípios & 16 Municípios & 4 Municípios \\
\hline
\end{tabular}

Fonte: Próprio autor, CAMARGOS (2005), IBGE (2010); IBGE (2015); ADMBH (2016); CBHRV (2015).

Todavia, mesmo com uma forte presença do aparelho estatal ao nível metropolitano, ainda não se consolidou uma efetiva participação social pública nos processos de tomada de 
decisões (FREY, 2012; BONTEMPO et al., 2012), o que favoreceria o surgimento de novas possibilidades de lideranças, aprendizagens institucionais etc, tal como já destacou GARSON (2009). E ao mesmo tempo em que há uma crescente institucionalização na gestão hídrica desta área, ela sofre dos mesmos problemas encontrados em outras RMs brasileiras, tais como a da bacia do Rio Gravataí (RS), que abarca Porto Alegre, ou a bacia do Alto Tietê (SP), que abarca São Paulo: complexidade das interações institucionais; níveis variados de demandas sociais; problemas ambientais crescentes etc (TUCCI, 2001).

E esse cenário de maior colaboração municipal inter-regional identificado no CBHRV é diferente, por exemplo, do CBH Litoral Norte (SP) ou CBH da bacia do Rio Itapicuru (BA). Nesses organismos de bacia há um histórico mais concorrencial e clientelista, mas não tanto ao nível “(...) de algumas alianças, independentes de posições partidárias.”, da maneira como é encontrado no CBH-PCJ (Minas Gerais e São Paulo) - já citado como exemplo sobre a construção de uma identidade regional.

Mais uma vez cabe destacar que, se por lá existiram alterações nas políticas públicas de recursos hídricos a partir de alterações no governo estadual, tal influência não se mostrou com o mesmo impacto em Minas Gerais. Provavelmente essa manutenção do modelo político nesse estado seja mais observada pelo perfil partidário em atuação no período de intervalo dessa pesquisa (1998-2012), que verifica as 4 primeiras presidências do CBHRV.

Isso porquê, ao retomar a análise sobre o contexto político de Minas Gerais, vale relembrar que no recorte de 14 anos sobre a atuação do CBHRV, Minas Gerais foi governada pelo PMDB durante 4 anos no governo de Itamar Franco (com apoio dos setores de centroesquerda) e pelo PSDB via os governos de Eduardo Azeredo, Aécio Neves e Antônio Anastasia (com apoio do PMDB e de suas lideranças em quase todo o período) durante 10 anos. Nesse período, de acordo com alguns entrevistados durante a pesquisa, houve a manutenção de um modelo de gestão ambiental fortemente acoplado com políticas desenvolvimentistas liberais e próximas aos interesses dos segmentos industriais/mineração.

Por outro lado, o desenho institucional do CBHRV delimitou objetivamente desde seu início (CUNHA; THEODORO, 2014), via Deliberações Normativas (DNs), um viés de gestão mais favorável à atuação da sociedade civil, mesmo que sua origem tenha sido claramente influenciada pelo Estado. Isso demonstra, por um lado, uma tentativa dos movimentos sociais se contraporem a tal postura política desenvolvimentista e de racionalização do Estado e, por 
outro lado, a capacidade das lideranças do CBHRV em se articularem nos bastidores das políticas públicas para se posicionarem conjuntamente ao governo estadual. Porém, críticas ao forte posicionamento do Estado dentro da lógica de articulação do CBHRV, que deveria ter mais capacidade de exercer pressão por suas deliberações existem e indicam que as preocupações sobre uma captura do Estado por interesses setoriais estão presentes.

Isso tornou esse comitê com menos conflitos identificados do que, por exemplo, os que ocorreram no Comitê de Gerenciamento da Lagoa da Conceição (SC), onde os poderes municipal/estadual e usuários estiveram em conflito em algumas ocasiões desde sua formação em 2001. Em Minas Gerais, e, sobretudo, no CBHRV, a política de negociação entre pares (GIL, 2008) se tornou uma característica recorrente mais do que conflitos explicitamente estabelecidos (THEODORO, 2002; COSTA, 2008; MOREIRA, 2013; THEODORO e MARQUES, 2014).

Mas para se ampliar uma reflexão sobre o cenário político envolvido na gestão do Rio das Velhas, vale identificar que durante o período de pesquisa estabelecido, 1998-2012, o país possuiu três diferentes governantes federais, e dois partidos de coligações partidárias diferentes:

1) Fernando Henrique Cardoso, sociólogo, Partido da Social Democracia Brasileira (PSDB), entre $1^{\circ}$ janeiro de 1995 a $1^{\circ}$ de janeiro de 1999 e entre $1^{\circ}$ de janeiro de 1999 a $1^{\circ}$ de janeiro de 2003 ;

2) Luís Inácio Lula da Silva, metalúrgico, Partido dos Trabalhadores (PT), entre $1^{\circ}$ janeiro de 2003 a $1^{\circ}$ de janeiro de 2007 e entre $1^{\circ}$ de janeiro de 2007 a $1^{\circ}$ janeiro de 2011;

3) Dilma Vana Rousseff, economista, Partido dos Trabalhadores (PT), entre $1^{\circ}$ janeiro 2011 a $1^{\circ}$ janeiro 2015 ( $1^{\circ}$ mandato).

Ao se fazer uma comparação entre os cenários políticos dos governos nacionais e regionais expostos, em termos práticos o panorama é que entre os anos de 1998 e o final de 2002, o estado de Minas Gerais, via Eduardo Azeredo e Aécio Neves (PSDB) esteve na mesma base governista federal (Fernando Henrique Cardoso, PSDB) e que entre 2003 até 2012, via Aécio Neves e Antônio Anastasia (PSDB), esteve na base oposicionista ao governo federal (Luís Inácio Lula da Silva; Dilma Vana Rousseff; PT). 


\subsubsection{O período de gestão institucional neoliberal}

Como anteriormente colocado, a base de atuação para políticas públicas ambientais a partir da segunda metade da década de 1990 foi primordialmente moldada a partir das perspectivas de atuação das coligações coordenadas pelo PSDB e ao nível estadual:

Políticos de características tradicionalmente neoliberais e que promovem medidas tradicionais de gestão ambiental, baseadas em alto nível de controle institucional e político das organizações, fortes laços com o setor industrial (no caso, FIEMG, principalmente) e projetos de infraestrutura urbana passíveis de críticas. (BONTEMPO et al, 2012, p. 12).

Essa configuração acabou por estabelecer uma histórica política regional onde a presença governamental se consolidou por todas as esferas de decisão sobre recursos naturais e dos recursos hídricos, em particular. Mais ainda, o modelo desenvolvimentista com foco em subsídios industriais de largo porte e aparelhamento técnico para a tomada de decisões ajudou também a moldar um sistema de tomada de decisões igualmente técnico e com possibilidades aquém das demandadas para a participação efetiva da sociedade civil organização e do público comum em geral.

Uma possível explicação para esse contraste entre a demanda por maior participação e deliberação dentro das políticas públicas participativas emergentes após as décadas de 1980 e 1990 e o posicionamento refratário e desenvolvimentista mineiro pode ser encontrado no modelo de racionalidade institucional, inicialmente aplicada no governo de Eduardo Azeredo (1995-1999).

Esse posicionamento está adequado, inclusive, ao alerta de Swyngedouw (2005) e também Castro (2005) de que a racionalidade governamental cada vez mais acontece pela reformulação do Estado em um contexto de atuação neoliberal. Tanto que, nesse período começou a implantação de políticas de privatização dos sistemas de serviços do estado de Minas Gerais, inclusive em seu sistema financeiro, como o Banco de Crédito Real de Minas Gerais e, principalmente, o Banco do Estado de Minas Gerais (BEMGE).

Em relação a instituições vinculadas ao meio ambiente, Eduardo Azeredo tentou privatizar empresas do setor elétrico, tais como Furnas e, com destaque, a Companhia Energética de 
Minas Gerais (CEMIG), onde houve venda de ativos que alcançaram mais de um terço de suas ações transferidas ao setor privado.

Essa situação foi posteriormente modificada pela atuação do governador Itamar Franco que, sendo do PMDB e com apoio dos setores de centro-esquerda, conseguiu reverter e anular esse acordo de acionistas via poder judiciário, uma vez que ele não havia sido discutido e aprovado na Assembleia Legislativa do Estado. Da mesma forma, Itamar Franco se posicionou fortemente contrário ao movimento de privatização de Furnas e dos setores públicos como um todo. Ele se posicionou na direção de uma recuperação dos serviços públicos, com base em uma melhor organização do desenho institucional existente e que havia sido parcialmente atingido pela perda de patrimônio oriunda das ações dos últimos dois anos de mandato de Eduardo Azeredo.

Assim, a atuação da forma com que os recursos hídricos foram incorporados à agenda pública deve ser compreendida dentro de um contexto de forte presença dos órgãos governamentais, dos níveis municipais, regionais e nacional. Ou, como afirma uma liderança entrevistada,

(...) a agenda da água em Minas Gerais não é uma agenda de governo prioritária. (...) Quem define a pauta de água em Minas Gerais não é o comitê, é a ANA. O próprio IGAM não domina o número de outorgas, imagina a agenda como um todo, então!

Certamente que isso possibilitou ao CBHRV ficar mais susceptível ao encontro dos interesses governamentais/usuários baseados normalmente em comando-e-controle, de viés institucional $^{62}$, do que aos interesses dos movimentos sociais de representação-participaçãodeliberação, de viés social.

A própria questão das agendas políticas paralelas às decisões dos organismos de bacia e da agenda das políticas públicas hídricas tem sido fundamental para a compreensão dos limites mesmos, principalmente os CBHs. A ver, como já descrito em (BISWAS, 2008), os interesses envolvidos na gestão dos recursos naturais são colocados no formato intersetorial. E esse formato normalmente acarreta crescentes custos operacionais, jurídicos e sociais em várias áreas (HELLER e CASTRO, 2007; FREY, 2001; LISBOA, 2012; LUCHINI, 2000; MACHADO, 2003(a));

$62 \quad$ ASSUVE (2005).

Programa de Pós-graduação em Saneamento, Meio Ambiente e Recursos Hídricos da UFMG 
Outro fato relevante é analisar o que representou longitudinalmente os 12 anos sequenciais de governos do PSDB e suas coligações (Aécio Neves, Antônio Anastasia, Alberto Pinto Coelho) em Minas Gerais. Como descrito, baseados destacadamente sob o viés de uma racionalização da máquina pública pelo “choque de gestão” iniciado inclusive anteriormente, no governo de Eduardo Azeredo, a partir de 1995, os modelos de cunho neoliberais em bens e serviços públicos foram formalmente implantados em seus planos, programas e projetos. Ao discurso da implantação de políticas anticíclicas para contenção de gastos e, também, estimular a economia mineira, adicionou-se o pressuposto estímulo ao setor industrial.

Vale nesse sentido citar o caso da Companhia de Saneamento de Minas Gerais (COPASA MG), criada em 5 de julho de 1963, por meio da Lei Estadual n ${ }^{\circ} 2.842$, a partir da Companhia de Água e Esgotos (COMAG), com a missão da execução de programas de saneamento básico em Minas Gerais. A COPASA foi paulatinamente sendo modificada de seu perfil público para implantação da infraestrutura de serviços de saneamento, para um perfil de uma empresa de economia mista (com participação acionista privada-pública).

Em 2006, a COPASA oficialmente se tornou uma companhia de captação de recursos econômicos e financeiros no mercado de capitais ao realizar sua Oferta Inicial de Ações (Initial Public Offering-IPO). Tal ação possibilitou à empresa sua inserção no chamado "Novo Mercado" da Bolsa de Valores de São Paulo (BOVESPA), que significa um segmento específico de empresas com práticas de governança (corporativa) estabelecidas em seus estatudos (COPASA, 2017).

Essa mudança significa que atualmente a COPASA primeiro responde aos interesses de seu grupo de acionistas (dentre os quais o Estado mineiro é principal deles) em uma perspectiva de retorno de seus investimentos econômicos mais do que dos possíveis impactos sociais envolvidos. O que acaba por gerar críticas constantes do setor da sociedade civil sobre como a questão do saneamento nas bacias hidrográficas mineiras (apesar de não estar a COPASA em todos os municípios do estado) poderá ser melhorado em um cenário de investimentos focados em dividendos de curto prazo.

Além disso, a COPASA foi citada como uma empresa que detém viés de poluidora dos recursos hídricos no exercício de suas atividades, o que se adiciona ao cenário de diagnóstico de problemas ambientais diversos em Minas Gerais.

Programa de Pós-graduação em Saneamento, Meio Ambiente e Recursos Hídricos da UFMG 
De acordo com a Secretaria de Estado do Meio Ambiente, em relatório do Governo de Minas Gerais em $2015^{63}$ " numerosos processos administrativos parados: 2.700 processos de licenciamento; 5.300 processos para intervenção florestal; 110.000 autos de infração, equivalentes a mais de 150 milhões de dólares. Mais ainda, especificamente para a área de recursos hídricos, existem mais de 14.000 outorgas para uso não liberadas. De acordo com tal documento, as principais atividades afetadas incluem as relacionadas com mineração, indústria química, serviços e comércios em geral.

Mesmo que publicado a partir da atuação do novo governo eleito pelo Partido dos Trabalhadores, na gestão de Fernando Pimentel (2015-2018), os números podem ser considerados forte indicadores das práticas neoliberais utilizadas nos anos precedentes. $\mathrm{O}$ déficit público instalado, ao redor de 2.5 bilhões de dólares, para valores de 2015, foi identificado pela Controladoria-Geral do Estado, que também constatou a perda da capacidade de gerenciamento em Minas Gerais, com aumento considerável no custeio administrativo e contratos sem gerenciamento integrado, com comprovação de gastos.

O que dota de nexo as afirmações recorrentes nas entrevistas realizadas de que há um crescente desmantelamento do IGAM em especial, e dos órgãos ambientais, em geral, no território mineiro. Mais ainda, houve uma ênfase grande em que nos últimos anos, principalmente com o advento do governo de Antônio Anastasia (2010-2014-PSDB), tal desestruturação foi acentuada e que os programas de governo não estabeleceram uma participação mais ativa da temática de recursos hídricos na agenda estatal. Esta agenda, segundo as lideranças, está cada vez mais permeada dos interesses dos setores produtivos, destacadamente a mineração e setor agrícola.

Como exemplos, tem-se a argumentação de representantes do setor dos usuários: 1) “(...) há muita omissão do Estado, que é o órgão executor, e o IGAM tem sofrido muito esvaziamento em sua estrutura.”; 2) “(...) hoje o IGAM não domina nem o número de outorgas que concede. Imagina o sistema como um todo..."; ou da AGBPV: "O IGAM estava muito distanciado do cotidiano dos comitês e agora está se reaproximando. Mas pode demora para esse processo acontecer de novo.”; ou do segmento do poder público estadual: “(...) o pior é que não há nem um banco de dados ou controle pelo IGAM. Por exemplo, sobre as mineradoras e isso é dificil.".

63 Vide www.diagnostico.mg.gov.br.

Programa de Pós-graduação em Saneamento, Meio Ambiente e Recursos Hídricos da UFMG 
Mais ainda, há um esforço em se legitimar o discurso neoliberal desde as décadas de 1980 e 1990 em relação ao setor hídrico e isso não acontece(u) sem propósito. Esse movimento tem como objetivo, como pontua Castro (2005) e Swyngedouw (2000), criar hegemonias ideológicas e políticas crescentes em países em desenvolvimento que são, em última instância, muito dependentes de capital estrangeiro e que não pensam a água como um "ativo ecosocial” (SILVA, 2015).

Nesses locais não há uma força política e social e/ou estadual suficientemente forte para se opor às atividades corporativas. A consequência é que “(...) a viabilidade comercial das empresas privadas se converteu em um objetivo social." (CASTRO, 2005, p. 14), tornando os serviços privados de água e saneamento um fim em si mesmo, sem objetivos sociais, tanto em seus planejamentos, quanto nas implantações.

Isso porque, a questão da gestão de recursos hídricos em Minas Gerais e, em particular na bacia hidrográfica do Rio das Velhas, só pode ser compreendida a partir dos elementos políticos e econômicos anteriormente discutidos (desestruturação do Estado; iniciativas neoliberais a partir dos anos 1990; direcionamento de políticas públicas desvinculadas dos interesses socioambientais etc). E eles indicam fortemente que, tal como indica Johnsson e Lopes (2003, p. 77),

\footnotetext{
Alterações no governo estadual, normalmente, acarretam alterações de políticas, ao passo que alterações em nível municipal ou nas regiões administrativas, normalmente, são acompanhadas por uma manutenção do status quo.
}

O que indica que há realmente um descompasso entre as políticas de nível micro e macro regional para a gestão hídrica no país, o que salienta a importância de processos integrados de longo prazo.

\subsubsection{O que os estudos de casos revelam}

Impera observar desde o início de um exercício de análise comparativa a indicação de Wostl e Kranz (2010) de que a utilização de casos muito detalhados e/ou específicos podem na verdade dificultar que a mesma (análise) aconteça. Isso significa que deve haver abordagens que considerem o contexto e problemática de cada situação (HELLER, 2012), ao mesmo tempo em que se mantém um nível de generalidade capaz de gerar a possibilidade de indicadores para ações futuras.

Programa de Pós-graduação em Saneamento, Meio Ambiente e Recursos Hídricos da UFMG 
Nessa direção, primeiramente, o que mais se destaca em comum nos casos levantados é que a noção de gerenciamento sobre recursos hídricos utiliza de forma crescente o conceito de "bacia hidrográfica" como unidade para planejamento de ações institucionais ou estruturais, e de "comitê de bacia hidrográfica" como o principal elemento para ações políticas ou administrativas. Isso significa que os instrumentos para o gerenciamento têm caminhado, mesmo que em ritmos muito diferentes, na busca de uma consolidação de mecanismos de integração, seja na prática ou em teoria (GREEN, 2007).

Contudo, tais mecanismos (que no caso brasileiro significam diretamente os cinco instrumentos de gestão de recursos hídricos: enquadramento, plano diretor, sistema de informações, cobrança e outorga) são ainda muito dependentes de fatores interdependentes da gestão em si - dos sistemas políticos e institucionais de decisão. É de interesse notar que esses desafios institucionais para a gestão já eram indicados em alguns estudos do início dos anos 2000 (ver LUCHINI, 2000; THEODORO, 2002; JOHNSSON e LOPES, 2003).

Outro fato que chama a atenção é que, paulatinamente, como ocorre nos casos levantados, assim como Índia, Nigéria ou África do Sul, citados em Biswas (2008) e também em Roy (2005), a temática hídrica deve ser considerada em um lócus e em uma dinâmica própria. E não em uma instituição única, com regras que tem de incorporar, mas, na verdade, excluem campos que são interdependentes. Isso traz à discussão a afirmação de Wostl e Kranz (2010) de que seria importante, dentro dos procedimentos de gestão de políticas públicas de recursos hídricos, que haja espaços de atuação de um “adaptative management”. Isso poderia tornar possível que aumentos de performance institucional ocorressem, via descentralização de bens e serviços.

De forma geral o que se identificou é a gestão integrada de recursos hídricos ainda é uma política em construção nas políticas públicas e seus impactos ainda são, segundo Biswas (2008), marginais, seja em relação à sua inclusão nas discussões nas agendas públicas e, principalmente, nas implantações de políticas que são para além de projetos de infraestrutura. Os desafios para a consolidação de uma gestão participativa e integrada dos recursos hídricos não residem simplesmente nos tamanhos e/ou localizações geográficas das bacias hidrográficas em questão.

Eles estão também no tamanho dos seus respectivos governos, que poderiam gerar menos ou mais conflitos de interesses, mas sim como esses possíveis conflitos são gerenciados para 
consensos coletivos futuros ${ }^{64}$. Tanto que para Rothsthein e Teorell (2008) o tamanho que um governo possui não seria capaz de determinar a qualidade que este governo exerceria sobre seus cidadãos, mas sim sua capacidade em seguir as regras do jogo institucional estabelecido.

Consequentemente, as diferenças existentes entre os diversos organismos de bacia em termos de suas atuações, processos e resultados podem estar vinculadas diretamente ao fato que Abers (2007; 2009; 2010); Johnsson e Lopes (2003); e Luchini (2000) identificam como leituras e aplicações distintas da 9.433/97 e, também, das leis estaduais efetuadas pelos diferentes grupos de interesses envolvidos ${ }^{65}$.

Isso se dá não só pelas distintas disposições políticas existentes em cada bacia hidrográfica, como também pelas diferentes relações formais e informais envolvidas. E no Brasil essa situação pode ser quase que definidora do sucesso ou não de uma dada política pública ao nível municipal ou regional. Para o exercício de políticas hídricas melhor estruturadas e com maior capacidade de permanência no tempo (efetividade) e no espaço (descentralização), a capacidade dos CBHs pesquisados, em gerar e manter alianças se mostra fundamental para tal sucesso. Pois por um lado essas alianças formalizadas ou de bastidores (ABERS, 2007; LISBOA, 2012), criam novos ambientes de interações e, por outro lado, possibilitam (re)arranjos institucionais inerentes aos processos de gestão e ao diversificado contexto brasileiro (ALMEIDA, 2007).

Como salienta Johnsson e Lopes (2003), as instituições formais brasileiras são historicamente frágeis e pouco abertas para a participação do cidadão comum, salvo a partir do período-pós ditadura $^{66}$. E como também destaca Abers et al (2005) e Theodoro (2002), essa característica de um "engessamento institucional" deve ser considerada para a gestão participativa das políticas públicas, uma vez que o país possui um alto índice de descentralização físcal, fragmentação política e fortes elites locais. E como já colocado, vários organismos de bacia, criados por pressão social ou governamental, tiveram maior ou menor desenvolvimento

64 O CBHRV ou o CBH Paracatu, por exemplo, estão entre as maiores bacias hidrográficas do estado de Minas Gerais e, mesmo assim, têm apresentado gestão mais consistente e capacidade de interação institucional do que outros comitês regionais. O CBHRV, inclusive, é atualmente (2016), o comitê com maior capacidade de arrecadação de recursos advindos da aplicação do instrumento de cobrança pelo uso múltiplo dos recursos hídricos de sua bacia hidrográfica (IGAM, 2016; PIH, 2016).

65 Da mesma forma, como exposto em Veiga e Magrini (2013), para o contexto internacional.

66 Assim como em outros países latinos (TRAWICK, 2005; FREY, 2012; TORTAJADA e CASTELÁN, 2003; CASTRO, 2005; BOURLON e BERTHON, 1998).

Programa de Pós-graduação em Saneamento, Meio Ambiente e Recursos Hídricos da UFMG 
organizacional, assim como o envolvimento entre seus participantes de acordo com as alianças políticas exercidas.

Nesse sentido, os CBHs e consórcios podem ser compreendidos mais como espaços para a formação de acordos (consultivos) sobre questões essencialmente públicas do que para o controle do Estado e do setor privado, pela sociedade em geral (deliberativos) (ABERS et al, 2009; CUNHA; THEODORO, 2014; LISBOA, 2012). Consequentemente, os níveis de influência nos processos institucionais por parte desses organismos de bacia serão proporcionais ao(s) nível(is) organizacional(is) que possuem em termos formais e também informais. Em termos de suas possibilidades de exercerem colaboração entre as partes internas e externas aos seus processos de decisão (ANSELL e GASH, 2007).

Os CBHs demonstram-se como novas propostas e práticas de participação que só recentemente foram incorporadas às políticas de gestão pública. Tais como, por exemplo, os conselhos de políticas presentes, por exemplo, na Lei Orgânica de Saúde (LOS) e da Lei Orgânica da Assistência Social (LOAS) - como visto em Avritzer, 2008; assim como de planejamento público (Planos Diretores Municipais, Orçamentos Participativos, etc) - como discutidos em Menegat, 2000; Abers, 2010; Cunha, Theodoro, 2014; Avritzer, 2008.

$\mathrm{Na}$ verdade, as críticas ao real alcance e influência que arenas de consulta e deliberação em geral (e organismos de bacia em particular) conseguem exercer no cotidiano dos processos de tomada de decisão encontra suporte em crescente bibliografia nacional e internacional sobre o tema (FUNG e WRIGHT, 2003; COSTA, 2008; GUERRERO et al., 2015; SWYNGEDOUW, 2005; EMPINOTTI, 2011; CASTRO, 2005). Como salienta uma liderança do segmento dos usuários de água entrevistada,

O fato é que a sociedade não vê ou não tem essa preocupação de participação como prática da gestão, não. Vê somente os direitos, sem os deveres, sem o peso do acompanhamento que tem que ser feito para as coisas darem certo. (...) O importante é que o Velhas deve ser visto como local de articulação política, principalmente.

O mesmo foi identificado em trabalhos comparativos sobre a literatura de políticas públicas e/ou meio ambiente (GREEN, 2007; TRAWICK, 2005; TOTTI e AZEVEDO, 2013; OLIVEIRA, 2006; THEODORO e MATOS, 2015; BRANNSTROM et al., 2004). É uma tendência deve ser considerada como um indicativo sobre o longo caminho que as políticas 
públicas de recursos hídricos ainda devem avançar rumo ao aumento da descentralização administrativa e da participação social.

No caso do CBHRV, tanto a presença de líderes na criação como na retomada dos trabalhos do comitê após sua primeira presidência foram fundamentais para o estabelecimento de objetivos adequados a cada contexto. Além, assim como o CBH Paracatu, o CBHRV passou anos discutindo e definindo suas regras e regimento interno para, a partir daí, começar a decidir sobre questões fundamentais de operação de atividades, como a instalação dos instrumentos de gestão, equipe de mobilização social, etc. Foi feito consequentemente um processo, paulatino, da criação de uma rede de contato e de trabalho que consolidou novas oportunidades de ação (JOHNSSON e LOPES, 2003) ao longo dos mais de 15 anos de existência desse comitê.

Por outro lado, um fato identificado comparativamente, e que já havia sido colocado em Frey (2012) e em Empinotti (2011) é que tanto os consórcios municipais como os comitês de bacia são iniciativas institucionais promissoras, porém, não consolidadas e também distantes em questão dos resultados inicialmente pretendidos ${ }^{67}$. Essas propostas versavam sobre novas práticas colaborativas de gestão integrada e participativa, perspectiva que também pode ser encontrada em Veiga e Negrini (2013) quando se considera as primeiras duas décadas que estão a se consolidar para a PNRH (a partir das definições da Lei Federal nº 9.433/97, com suporte das leis estaduais).

Como pode ser visto em FUNG e WRIGHT (2003), existem muitas dificuldades na consolidação de perspectivas de participação mais justa e democrática. O Brasil, por exemplo, se caracteriza como um país com forte autonomia municipal em um estado federativo que é omisso com as regiões metropolitanas (FREY, 2012), em um cenário que acaba por dificultar ações locais recorrentes, pois

(...) o processo de descentralização e participação não é apenas difícil de ocorrer no Estado, mas também em outros setores da sociedade. A representação centralizada reflete as práticas da democracia participativa fortemente enraizada nas práticas políticas brasileiras. (EMPINOTTI, 2011, p. 203).

E ao se considerar o Brasil dentro do cenário mundial, Veiga e Negrini (2013) apontam que o modelo existente no país foi primeiro empregado nas regiões mais desenvolvidas do território

67 A ver, sobre os comitês e consórcios, respectivamente, os Arts. 41 e 42 da Lei Estadual n ${ }^{\circ} 13.199$, de 1999, para o âmbito mineiro; e os Arts. 37 e 47, respectivamente, da Lei Federal n 9.433, de 1997.

Programa de Pós-graduação em Saneamento, Meio Ambiente e Recursos Hídricos da UFMG 
e naquelas onde havia maiores problemas em relação à qualidade e quantidade de água. O que é observado é que esse direcionamento caracterizou ações de curto prazo e de resultados assimétricos em relação ao acesso da população aos serviços hídricos - algo visto também em UNU (2014). Em geral o modelo como um todo ainda não está completo e algumas sugestões para seu aprimoramento devem ser consideradas: fortalecer a coordenação entre governo federal e estadual; implementar o enquadramento dos corpos d'água; acelerar a implantação de IWRM em regiões menos antropisadas e com foco em gestão preventiva; considerar a adoção de algum tipo de sistema de mercado de água.

De forma geral o que houve nos países periféricos, como na América Latina, foi um aumento da desigualdade de acesso aos desfavorecidos. Isso porquê a introdução da racionalidade econômica para melhorar a gestão hídrica e seus serviços foi confundida com introdução à racionalidade mercantil, que transforma os recursos econômicos em fim e não instrução de ação (BARDHAN, 2004 e, principalmente, GUERRERO et al., 2015).

A forte presença da figura do Estado como, se não o principal (e até mesmo único, como na China), um dos principais atores nos processos de tomada de decisões também foi identificada na análise comparativa. Isso reflete que a estrutura institucional existente na maioria dos países foi pensada de forma mais descendente do que participativa e que ajustes estão em procedimento em vários países para dar conta das lacunas à participação (EMPINOTTI, 2011). Por outro lado, pode ser identificado o incremento de estruturação desse desenho institucional pela gradativa incorporação de instrumentos econômico-financeiros baseados em cobrança por uso múltiplo de recursos hídricos.

Todo esse contexto se assemelha bastante aos estudos de Harpham e Boateng (1997) que já indicavam que as tendências sobre desenvolvimento no mundo atual, a partir dos anos 2000s (e, por consequência, no Brasil) estariam muito baseadas na emergência de uma economia de mercado que estaria cada vez mais inserida em sistemas políticos pluralistas. Um contexto que pode ser considerado até certo ponto como $\mathrm{O}$ que indica que a interação entre as dimensões políticas, institucionais e econômicas são um caminho a ser frequentemente trilhado pelas políticas públicas em geral.

O problema é que os governantes têm pouco interesse em transferir poderes deliberativos para grupos formados por cidadãos comuns, com pouca ou nenhuma experiência além de votar, em processos que são complexos, frustrantes e que consomem variados recursos de seus 
participantes. De forma geral os estudos de casos indicam que essa inclusão ainda precisa acontecer.

No caso específico dos CBHs mineiros, e tal como destaca a discussão clássica de Putnam (1998), a inclusão da sociedade civil nas discussões políticas dos recursos hídricos se mostrou fundamental para o nível de capilaridade dos $\mathrm{CBHs}$ mineiros. Isso significa que aqueles comitês que souberam se articular politicamente junto aos poderes constituídos, e não apenas se mostraram resistentes aos mesmos, obtiveram um reconhecimento e legitimidade mais amplos do que naqueles onde houve pouca interação política-administrativa. O que leva à afirmação de uma liderança entrevistada do setor dos usuários de que “(...) longe da sociedade não se gerencia recursos hídricos. Ainda mais em uma área onde acontece omissão do Estado.”.

Nessa mesma linha de raciocínio, a questão da transparência no acesso a informações sobre o cotidiano dos comitês é bastante diferente entre os CBHs mineiros, o que demonstra diferentes estruturas de funcionamento. Enquanto alguns possuem páginas na internet com muitas informações, atualizadas, de seus cotidianos (casos do CBHRV, $\mathrm{CBH}$ Araguari, CBH Pará). Em outros, essa possibilidade de acompanhamento social é mais difícil, ao menos virtualmente. Porém ao se verificar as datas de fundação, história de formação e até também notícias na mídia e eventos realizados, é possível se identificar que os CBHs mais recentes têm demonstrado maior capacidade de comunicação social juntos aos seus parceiros e comunidade em geral.

É um fato demonstrativo também que há um processo de aprendizagem institucional sobre como funcionam os organismos de bacia e da importância de espaços de negociação entre grupos de interesses tão diversos como os que são normalmente presentes na gestão hídrica participativa. Ao mesmo tempo, também, as pesquisas de campo (em eventos e reuniões técnicas) demonstraram pouco conhecimento que os representantes têm da realidade dos outros comitês ou de como fazer interagir os mesmos dentro do sistema de gestão, apesar da existência de encontros regionais, estaduais e federais de CBHs. 


\subsubsection{Características de comitês que avançaram na gestão das políticas públicas de recursos hídricos}

De forma a estabelecer os principais pontos de orientação que motivaram alguns dos comitês em relação ao tipo de ações que realizaram em seu histórico institucional, adiante são discutidas, a ver:

> Começaram pequenos: os comitês de forma geral têm um início de atividades gradativas, via projetos-pilotos e normalmente somente com o passar dos anos conseguem estabelecer rotinas de atividades e, mesmo assim, apenas quando há uma consolidação administrativa e de participação social mínima. Isto significa uma agenda de reuniões e, eventualmente, câmaras técnicas de assessoria, aliada a eventos culturais e acadêmicos.

$>$ Projetos de fácil assimilação: os atores participantes, principalmente a sociedade civil, foram incluídos na estrutura dos comitês que se mantém em destaque justamente por terem atividades focadas, direcionadas, de curto, médio e longo termos. Principalmente projetos com resultados que puderam ser mensurados, de forma direta, pelos participantes, computou a favor do reconhecimento dos comitês que assim o fizeram pelos participantes de seus segmentos. Exs: Velhas (MG); Gravataí (RS); São Francisco (Nacional).

$>$ Forte interação social interna: em vários casos, os comitês onde os participantes tiveram mais interação em suas atividades, com maiores possibilidades de expor ideias, discutir programas e se conhecerem por conta disso, demonstraram maior capacidade de decisão. Isso não quer dizer, entretanto, que processos de conflitos ou discussões com posições antagônicas não sejam identificados. Exs: Paraíba do Sul (MG/SPQ/RJ); Gravataí (RS).

Dventos: Realizaram diversos eventos de formação e agremiação, tais como educacionais, culturais ou meramente festivos. Mais ainda, eventos regulares, mesmo que anuais (tais como de comemoração da data de formação dos comitês, por exemplo), indicaram ser capazes de dar uma personalidade a cada comitê. Também se identifica que as repetições de eventos fortalecem laços institucionais e pessoais que não são desenvolvidos da mesma forma quando em ambientes próprios das rotinas dos encontros nos comitês. Exs: Pará (MG); Velhas (MG); PCJ (MG/SP). 
Valorizaram as "pequenas vitórias": como destacaram Ansell e Gash (2007), a complexidade diária que existe para que um organismo de bacia funcione pode ser minimizada na direção da integração quando cada nova conquista é celebrada. Isso significa valorizar um novo projeto ou parceria que é iniciado(a); quando há o melhoramento de algum processo (como o aumento da participação dos municípios ou usuários de água, por exemplo). Exs: Velhas (MG); Gravataí (RS); Pará (MG).

Atuação ao nível local: a contínua e crescente mobilização ao nível local, principalmente, ao invés de atuação de macro políticas que esparsam ações e podem mitigar esforços e resultados, mostrou o fortalecimento dos comitês que assim optaram. Por um lado, esses CBHs passaram a compreender melhor os seus atores institucionais integrantes e, por outro, passaram a ser a ponte entre as demandas locais e a estruturação e aplicação das políticas de recursos hídricos regionais. Alguns deles incluíram estratégias de atuação via subcomitês justamente para poderem firma atividades de gestão hídrica junto com suas populações locais. Exs: Tarumã-Açu (AM); Velhas (MG); Gravataí (RS); Afluentes Mineiros do Alto Rio Grande (MG).

> Investiram na profissionalização de seus quadros e de sua comunicação social: os CBHs que profissionalizaram sua comunicação institucional demonstraram que conseguiram alcançar resultados muito mais efetivos em termos de participação virtual (via sites) e, principalmente, física. Isso se deu por um aumento da quantidade e da qualidade das informações que foram posteriormente apresentadas ao público em geral, com a geração de novas alianças institucionais, projetos, eventos etc. Da mesma forma, identifica-se uma maior organização dos quadros existentes nos CBHs estudados, seja pela maior qualificação dos participantes das câmaras técnicas, como também pela melhor distribuição de tarefas (CTs), existência de grupo específico para mobilização social, etc. Exs: Alto Tietê (SP); São Francisco (Nacional).

> Obtiveram reconhecimento público: um dos pontos principais dos comitês mais estruturados se dá pelo reconhecimento que conseguiram construir junto ao público de seus territórios de atuação. Esse reconhecimento aconteceu tanto pelo incremento de suas comunicações, como também pela capacidade de entrega de resultados, a capacidade de integrar públicos diferentes e a possibilidade criada de gerar agendas sociopolíticas. Certamente que com o correr dos anos a tendência de aproximação entre os comitês e a população local foi se consolidando quando essas ações descritas foram repetidas e explicadas ao público em geral. Como explicado em Abers (2013), 
essa aproximação também cria uma autoridade de atuação que nem todos os organismos de bacia conseguem estabelecer sendo, ao mesmo tempo, um diferencial que tal aconteça para a diminuição de conflitos e o estabelecimento de parcerias. Exs: Velhas (MG); Pará (MG); Sinos (RS).

- Tiveram suporte acadêmico elou legal-administrativo para suas ações: como conhecimento e organização de suas atividades, os CBHs que tiveram suporte de IES e também de especialistas jurídicos e administrativos, culminaram por estabelecer uma perspectiva de onde, como e quando realizar suas demandas a partir do que é estabelecido na PNRH ou nos seus PDRHs. Consequentemente, conseguiram, em escalas diferentes, construírem calendários de atuação que tentam evitar o surgimento de agendas institucionais paralelas, seja com relação aos temas como às ações municipais. Exs: Araçuaí (MG); Velhas (MG); Gravataí (RS); Sinos (RS); Vacacaí e Vacacaí-Mirim (RS).

Transformaram seu capital social em capital político: o que significa que passaram da potencialidade de grupos heterogêneos com ao menos um interesse comum, o que define minimamente uma coletividade, para a efetividade de ações políticas específicas para a obtenção de resultados determinados. Os CBHs mais estruturados perceberam que apenas a atuação ao nível social sem o incremento também da atuação política, era menos efetiva do que inicialmente supunham. Nesse sentido, passaram a atuar mais nos bastidores dos processos de tomadas de decisão, a tentarem influenciar a formação das agendas e dos planejamentos públicos. Exs: São Francisco (Nacional); PCJ (MG/SP).

- Firmaram alianças políticas e partidárias (mais políticas do que partidárias): ao invés de se aterem às discussões e limites das alianças partidárias que permeiam o cotidiano político nacional (ALMEIDA, 2007), alguns comitês preferiram se articular de forma de atuação política que pudesse estabelecê-los como local de encontro de várias tendências e partidos. Isso porque a questão municipal, de poder local, pode ser encarada como um âmbito onde a política partidária é muito presente e seu desmerecimento pode comprometer a vontade política dos seus representantes públicos em participar dos comitês. Consequentemente após agirem nos bastidores a ação foi no sentido de influencia a agenda pública de alguma maneira, sendo que a incorporação de planos, programas e projetos na mesma foi o caminho encontrado. Isso criou uma maior possibilidade de pressão dos comitês para cobrarem dos poderes 
públicos resultados de suas ações. Exs: Velhas (MG); Pará (MG); Paracatu (MG); São Francisco (Nacional).

Certamente que as características levantadas não são unilaterais em relação aos $\mathrm{CBHs}$ estudados, o que significa que nem todos realizaram todas. Em geral os comitês desenvolvem parcialmente as ações identificadas. A questão de explicação sobre o sucesso ou não de um determinado comitê não pode ser buscado apenas "de fora para dentro", a partir de suas relações e influências exógenas, e de como foi "constituído" institucionalmente. Em realidade, deve ser buscado "de dentro para fora", a partir da forma como foi "construído" social e politicamente. É a partir disso que se podem identificar limites e potencialidades de atuação dos organismos de bacia que detenham ou não legitimidade (e não apenas funcionalidade) de ação.

\subsubsection{Como é pode ser compreendida a particularidade do CBHRV}

Dentro do que foi exposto no sentido do posicionamento do que representam os CBHs no momento atual dos recursos hídricos no país, é importante situar como pode ser compreendida a particularidade do CBHRV. Primeiramente essa medida é importante pois pode caracterizar como que o comitê especificado pode ser estudado, criticado e possivelmente desenvolvido, porém dentro de um contexto maior, contemporâneo.

Ao mesmo tempo, como a pesquisa busca a identificação das restrições e limites da gestão das políticas públicas de recursos hídricos via o estudo de caso do Rio das Velhas, a busca da particularidade do mesmo é consequência de análises comparativas. Para iniciar esse tipo de discussão, cabe salientar que o CBHRV não possui, essencialmente, nenhuma ação de gestão que poderia ser considerada como "diferenciada". Ao contrário, suas práticas remetem constantemente ao que se tem realizado em $\mathrm{CBHs}$ ao redor do mundo ou do próprio Brasil.

Por exemplo, em termos de sua gestão institucional:

Gestão por sub-bacias/subcomitês: Apesar de que outros comitês brasileiros admitem a gestão via sub-bacias como unidades mínimas de planejamento, no caso do CBHRV essa opção foi levada a termo desde o início de suas atividades. Foram cristalizadas não somente em Deliberação Normativa, mas como uma prática de atuação ao nível local, sem dúvida herdada do modelo de gestão existente do Projeto Manuelzão 
("Núcleos Manuelzão"). Porém, com o tempo houve um aperfeiçoamento da gestão neste sentido, ao alcançar as 23 UTEs permeadas por 14 subcomitês.

$>$ Origem via ação acadêmica: Como já discutido, o Brasil tem mais de uma dezena de IES que se aproximaram, desde o início ou após o lançamento, de vários organismos de bacia, principalmente os CBHs. No caso do Rio das Velhas o fato da UFMG ter participado, via Projeto Manuelzão e Faculdade de Medicina, até mesmo até do nascimento do seu comitê, trouxe bônus e ônus: bônus como suporte intelectual e organizacional de ação; ônus por criar uma vinculação tão forte entre a figura do Projeto Manuelzão e o CBHRV que, segundo alguns entrevistados, a população em geral e mesmo os técnicos da área tem dificuldades em distinguir os limites.

Origem via fundo internacional: Há um lado de formação institucional forçada que não pode ser desconsiderada na história do comitê em estudo. Concebido dentro de uma proposta de financiamento internacional criou uma praticidade institucional inicial que ajudou a criar e perpetuar características técnicas administrativas na lógica do comitê.

Divisão quadripartite: A opção por uma divisão quadripartite, que assume as diferenças de dinâmica entre poder público estadual e poder público municipal, o CBHRV possibilitou um incentivo seletivo para a participação local, o que não é visto usualmente em outros desenhos institucional. Soma-se a isto o posicionamento do comitê em favorecer projetos de nível micro, a divisão quadripartite pode não ter superado a possibilidade de conflitos internos, porém estabeleceu limites de atuação dos segmentos dos membros.

Subdivisões de fundos setoriais nos planos de investimentos: Os investimentos setoriais nos planos de investimentos do CBHRV têm mantido uma caracterização regular para infraestrutura, via projetos hidroambientais, planos de saneamento básico etc. Por um lado esta opção faz com que seja criada uma base operacional ao comitê, com possibilidade da não pulverização de recursos e capacidade de accountability, mas, de outro lado, há espaço e demanda para práticas que estejam mais vinculadas com formação qualitativa de seus membros em várias frentes (educação ambiental; legislação; mediação de conflitos, etc). 
Em uma análise comparativa, o que pode gerar caminhos de discussão é que o CBHRV não pode ser compreendido por praticar ações diferentes das que já ocorrem em vários outros comitês do pais. Ao contrário: ele é destacado como um comitê que justamente segue o ideário de composição de ações de transparência aliadas com ações de pressupõem política e formação de quadros cada vez mais profissionais. O que a análise da gestão de recursos hídricos via o estudo de caso do CBHRV pôde revelar é que suas particularidades se encontram menos no "o quê" foi realizado, formal e institucionalmente, e mais no "como" foram realizadas suas escolhas de articulação política e administrativa para operar sua gestão hídrica. As respostas se encontram muito mais no processo de construção das suas políticas do que nos produtos gerados pelos processos políticos em si. O sucesso em termos de reconhecimento público e de legitimidade do comitê se devem muito mais ao seu caráter de formação próxima aos movimentos sociais e acadêmicos, inclusive em seu caráter ideológico, e menos por ter em sua origem um caráter exógeno de formação via fundos bilaterais de investimentos públicos-privados.

Entretanto, a relação de conflitos que foi identificada sugere que há pressões contínuas para que a gestão seja cada mais dirigida aos interesses governamentais em questões como a liberação ou não de outorgas, a definição da aplicação de recursos ou mesmo na continuidade do forte caráter tecnicista, e não político, das discussões na gestão. O que remete ao alerta já feito por Simpungwe (2006) da possibilidade de organizações criadas para a prática das discussões e planejamentos democráticos acabem por se transformarem em legitimadores e espectadores das decisões governamentais. 


\section{A ESTRUTURA DOS ARTIGOS DE TESE}

\subsection{Artigos de discussão}

\subsubsection{Dimensão institucional}

Primeiramente, tem-se no artigo que trata sobre a questão institucional do comitê analisado, questão, as discussões "Sobre a governança das políticas públicas na institucionalização da gestão de recursos hídricos do Rio das Velhas, Minas Gerais, Brasil”. Ele descreve os principais processos de gestão de recursos hídricos existentes na bacia hidrográfica do Rio das Velhas e os analisa a partir de uma perspectiva de gestão participativa, que é contextualizada em termos dos critérios de participação, responsabilidade e transparência.

A discussão evidencia lacunas existentes nos processos de tomada de decisão e de definição da agenda institucional em relação à bacia hidrográfica do Rio das Velhas que, mesmo sendo considerada uma das mais importantes do Estado de Minas Gerais, ainda demanda maior conhecimento de seus processos institucionais de gestão. $\mathrm{O}$ artigo também igualmente acompanha as transformações institucionais na gestão dos recursos hídricos na bacia pesquisada e de como a gestão foi sendo progressivamente colocada na agenda pública.

Como suporte metodológico é proposta a utilização das principais documentações referentes ao desenvolvimento das políticas públicas vinculadas à gestão da bacia hidrográfica do Rio das Velhas, tais como atas, reuniões, legislações, deliberações normativas e afins. Aliado a esse rol documental serão incorporadas as discussões oriundas das entrevistas realizadas com as lideranças do CBHRV e dos dados levantados em campo pelo pesquisador.

Este artigo tenta discutir sobre os principais fatores de restrição (“constraints") existentes na gestão do CBHRV para alcançar um estado de "gestão participativa" de seus processos. Mais ainda, a intenção é a de identificar quais restrições são fundamentais para um encaminhamento das ações do comitê na direção de uma atuação ao mesmo tempo integrada a partir dos critérios de participação, responsabilidade e transparência selecionados para a compreensão da "gestão participativa" existe ou não no CBHRV. Este artigo também está construído de forma a discutir os modelos de gestão institucional aplicados ao CBHRV desde sua fundação até o período atual, pois, dessa maneira, poderá haver a identificação das possíveis experiências de caráter inovador na bacia referida (gestão por subcomitês, instalação

Programa de Pós-graduação em Saneamento, Meio Ambiente e Recursos Hídricos da UFMG 
de Unidades Territoriais Estratégicas, estrutura do Plano de Aplicação etc), assim como indicar tentar identificar caminhos para a consolidação de processos de gestão.

O referido artigo foi enviado, revisado e aprovado para publicação na Revista Eletrônica Científica da UERGS, classificação Qualis B3, Interdisciplinar.

\subsubsection{Dimensão de integração do CBHRV}

Já o $2^{\circ}$ artigo proposto, relativo à dimensão denominada "Integradora", explana sobre "Os desafios institucionais de gestão hídrica em um modelo de participação quadripartite: o caso do comitê da bacia hidrográfica do Rio das Velhas, Brasil”. Ele tem como questão central tentar apontar os principais obstáculos para a gestão do CBHRV, tanto em termos internos (entre seus membros) como externos (como comitê com outras organizações/instituições). Ele objetiva elencar as restrições para que os procedimentos de gerenciamento de recursos hídricos, em um modelo quadripartite como o do CBHRV, possam ocorrer de forma harmônica para atuação endógena (organizacional) e exógena (institucional).

Dentre suas possíveis contribuições pesa o fato de que o CBHRV é considerado um dos comitês com maior experiência em gestão participativa de recursos hídricos, porém ainda possui diversas arestas organizacionais e institucionais que não são reveladas claramente, tanto em sua dinâmica quanto em seu arcabouço legal estabelecido. Conseguir estabelecer relações entre os principais conflitos (latentes ou não) entre seus participantes poderá favorecer o entendimento de como melhorar processos de tomada de decisão em ambiente difuso e complexo como o de um comitê de características tão próprias e com formação muito heterogênea.

Dentre estas características vale salientar a existência da capital do Estado de Minas Gerais e de sua região metropolitana (RMBH) com características muito próprias (GARSON, 2009; BONTEMPO et al., 2012); o exercício de gestão via estruturação quadripartite; ter sido criado sob a influência de orientações advindas de organismos multilaterais (Banco Mundial) mas ao mesmo tempo ter forte vinculação desde seu início com movimentos sociais diversos; ser um dos mais antigos e de maior atuação no Estado de Minas Gerais (1998).

Por outro lado, a principal questão do artigo reside na discussão sobre a participação no comitê e em seus processos de tomada de decisões, uma vez que existe um modelo 
quadripartite que demanda constante interação interna e externa de seus membros, o que nem sempre ocorreu ou ocorre.

Além de uma discussão sobre o caráter institucional formador do CBHRV e também da AGBPV, o artigo descreve a estruturação formal demandada pelo comitê e suas interações internas e externas para sua manutenção e operacionalização. Da mesma forma, é discutido sobre como está posicionado cada um dos grupos formadores do poder quadripartite da bacia hidrográfica em questão (poder público municipal, poder público estadual, sociedade civil e grandes usuários) em termos políticos e institucionais. Visa-se assim colocar em análise até onde tal modelo tem funcionado na prática a partir de suas interações (projetos, planos municipais, participação nas reuniões, propostas de cada setor etc).

Cabe destacar que o referido artigo já foi enviado, revisado, aprovado e publicado na Revista de Água da América Latina (REGA), classificação Qualis B3, Engenharias I.

\subsubsection{Dimensão legal do CBHRV}

Adiante, no terceiro artigo, desenvolvido especialmente para dar conta da complexidade existente sobre a dimensão "Legal" da gestão de recursos hídricos, das políticas públicas e da construção da governança destas, a denominação de discussão vai à direção da "Descentralização e gestão de recursos hídricos sob o enfoque legal: em busca dos fatores de inovação institucional para ações concretas".

O objetivo geral deste artigo é o de pesquisar sobre quais os elementos jurídicos e institucionais reguladores dos processos de tomada de decisões em relação à gestão por bacia hidrográfica e, em específico, no CBHRV, tendo como base as determinações legais sobre gestão integrada, participativa e descentralizada. Ele visa contribuir no sentido de que ao estudar quais os possíveis fatores que ajudariam o gerenciamento hídrico a avançar em relação à resolução de problemas bem definidos ${ }^{68}$ (papéis dos participantes, planejamentos diferenciados etc), é possível visualizar que a dimensão legal é mais do que uma determinação e sim um dos elementos de gestão, com destaque para o incremento da participação social e política local. Cabe salientar, inclusive, que o campo jurídico tem sido cada vez mais analisado sob o ângulo de suas oportunidades para integração e descentralização institucional.

$68 \quad$ “...nada pode ser intelectualmente um problema se não tiver sido, em primeiro lugar, um problema da vida prática”. - MINAYO (2012).

Programa de Pós-graduação em Saneamento, Meio Ambiente e Recursos Hídricos da UFMG 
Por um lado, a pesquisa utiliza do conjunto legal-institucional vinculado com a gestão de recursos hídricos, direta ou indiretamente vinculado ao tema (como planos diretores, uso do solo, institucional etc), na medida em que eles podem favorecer ou distanciar a atuação integrada e descentralizada do CBHRV. Por outro, há a utilização da série de entrevistas realizadas (26) com as principais lideranças relacionadas, direta ou indiretamente, com a gestão de recursos hídricos no Rio das Velhas (especialistas, acadêmicos, líderes locais e representantes institucionais), a partir de uma perspectiva metodológica de triangulação de métodos essencialmente qualitativa (pesquisa de campo, entrevistas, análise documental).

Certamente que a compreensão das relações entre a AGBPV e o CBHRV em termos da definição do escopo de atuação de cada um (muito mais do que o aquele previsto em lei) é um problema nevrálgico a ser colocado, uma vez que ele pode ser considerado uma restrição ao uso adequado do arcabouço legal. Outro problema é sobre se a criação de novas ações práticas (a gestão por subcomitês ou a previsão de aumento de suporte aos municípios, por exemplo) pode ser verdadeiramente incorporada na gestão, com suporte não somente legal, mas também operacional para responder às demandas da população da bacia.

Sendo assim, o artigo discute sobre a hipótese de trabalho levantada de que há lacunas entre as determinações legais e as práticas efetivas na gestão dos recursos hídricos da bacia do Rio das Velhas e de seu comitê. O artigo foca sobre quais os fatores que demonstram as disparidades existentes entre o campo institucional-jurídico e os processos de gestão ao nível de bacia hidrográfica, no caso específico do Rio das Velhas.

Este artigo foi enviado, revisado e aprovado para publicação na Revista Brasileira de Engenharia de Biossistemas (BIOENG), classificação Qualis B3, Interdisciplinar.

\subsubsection{Dimensão econômico-financeira do CBHRV}

Finalmente, no $4^{\circ}$ e último artigo de discussão, vinculado com “ $A$ aplicação de investimentos econômico-financeiros para a construção da governança dos recursos hídricos em comitês de bacia hidrográfica", a dimensão a ser focalizada é a "Econômica-Financeira" e onde o objetivo geral de análise é sobre o estabelecimento das associações entre as demandas da bacia hidrográfica do Rio das Velhas, as determinações colocadas pelo CBHRV, a estruturação dos temas pela AGBPV no Plano de Aplicação e como tem acontecido a implementação dos investimentos estabelecidos.

Programa de Pós-graduação em Saneamento, Meio Ambiente e Recursos Hídricos da UFMG 
Por tratar de temática de crescente importância, por lidar com a questão da aplicação de recursos econômicos e financeiros que têm por base, principalmente, a cobrança pelo uso de recursos hídricos, o artigo poderá auxiliar na identificação do escalonamento dos investimentos existentes na bacia hidrográfica do Rio das Velhas e, consequentemente, no próprio modelo de gestão via comitês que está a ser utilizado atualmente. Também poderá colaborar no aprimoramento das relações institucionais entre comitês e suas respectivas agências de bacia, de forma a não manter assimetrias (de poder, de representação, de responsabilidades etc).

Foi realizada análise dos principais mecanismos legais e institucionais para a gestão dos recursos econômico-financeiros disponíveis (ou em via de captação, tais como fundos setoriais, parcerias e afins) para o CBHRV e de como estes propõem aprimorar a integração entre seus participantes, inclusive ao nível de maior participação municipal. A isto foi incorporado o conjunto de entrevistas com membros do comitê e de sua agência de água e especialistas direta ou indiretamente ligados ao mesmo em relação aos tópicos sobre investimentos de recursos na bacia.

Dentre os problemas em destaque a discutidos estão a questão da demanda por maior participação dos municípios via a possibilidade de projetos de intervenção (criação de planos diretores municipais, capacitação profissional etc) e das perspectivas para a implantação de programas e ações para maior participação dos usuários e da sociedade civil, assim como quais as diretrizes de definição de aplicação de recursos a partir de uma perspectiva de atuação conjunta entre os atores sociais e institucionais participantes.

$\mathrm{O}$ artigo discute de quais formas os recursos previstos pela cobrança de recursos hídricos estão a ser alocados e utilizados na bacia hidrográfica do Rio das Velhas, na direção de descobrir possíveis lacunas de investimentos, como também possíveis assimetrias destes. Desta forma são colocadas inferências sobre quais as áreas que mostram prioridades aos investimentos públicos plurianuais inseridos na gestão desta bacia hidrográfica específica. Ao final, pretende o artigo identificar qual o andamento dos recursos captados e aplicados para a gestão do Rio das Velhas e onde são identificadas as maiores dificuldades para que a gestão possa ocorrer de acordo com as determinações legais e administrativas (em termos de alocação de pessoal, material ou operacional).

Programa de Pós-graduação em Saneamento, Meio Ambiente e Recursos Hídricos da UFMG 
Artigo enviado, revisado e aprovado para publicação na Revista Recursos Hídricos, da Associação Portuguesa de Recursos Hídricos (APRH), classificação Qualis B3, Engenharias $I^{69}$.

Finalmente, e na direção de criar um panorama sobre como que cada item de tese está organizado em relação aos seus pares de análise, tais como os métodos, resultados, discussão, conclusões e referências, apresenta-se consequentemente a estrutura de tese desta pesquisa. Destacam-se os tópicos próprios de "Considerações Finais", onde é sintetizado o trabalho desenvolvido; "Referências", destinado a toda a relação de bibliografia direta ou indiretamente relacionada à pesquisa realizada; e "Apêndices", no qual está o roteiro de entrevista utilizado. 


\section{A INSTITUCIONALIZAÇÃO DA GESTÃO DE RECURSOS HÍDRICOS NA BACIA HIDROGRÁFICA DO RIO DAS VELHAS, MINAS GERAIS, BRASIL, SOB A ÓTICA DEMOCRÁTICA E PARTICIPATIVA $^{70}$}

\subsection{INTRODUÇÃO}

Considerada como uma das grandes questões em discussão sobre os cenários presentes e futuros da gestão de recursos hídricos no mundo e no Brasil em particular, o conceito de governança tem sido analisado e revisitado por diversos atores sociais, individuais ou institucionais, e com vários níveis de profundidade e entendimento. Mesmo não sendo uma unanimidade em termos de sua aplicação e, ou capacidade de explicação científica, administrativa ou política, o fato é que sua influência é inegável no cenário intelectual das últimas décadas e tem dado provas de fôlego a prosseguir em evidência.

E tal destaque não acontece por acaso; ao contrário, a análise da governança em suas influências nos cenários mais variados é fruto de um processo de reflexão institucional sobre quais as demandas que o complexo âmbito de atuação do Estado no mundo contemporâneo tem capacidade ou não de tentar dar respostas, em qual tempo, em qual lugar e para quais comunidades, ainda mais a considerar o campo ambiental de debate (GIDDENS, 2010; CUNHA; THEODORO, 2014).

Mesmo tendo surgido por meio de influências corporativas oriundas dos setores econômicofinanceiro de nível internacional (BANCO MUNDIAL, 1992), o conceito de governança, ou melhor, o de "boa governança", foi difundido em larga escala, menos por propor medidas de comando e controle tradicionais e mais por iniciar uma série de discussões sobre o (pretendido) aprimoramento das estruturas públicas por meio de processos de inclusão e controles sociais diversos. Certamente que tal posicionamento gerencial deve ser entendido dentro de um contexto e de um arcabouço teórico e institucional, o que não livrou o conceito de ser analisado de forma crítica desde seu surgimento.

Neste sentido, o presente trabalho busca identificar, sob a ótica democrática e participativa que fundamenta conceitualmente boa governança, a dinâmica institucional e organizacional existente em uma bacia hidrográfica determinada. A selecionada foi a do Rio das Velhas,

\footnotetext{
70 Artigo enviado, revisado e aprovado para publicação na Revista Eletrônica Científica da UERGS, classificação Qualis B4, Interdisciplinar.
}

Programa de Pós-graduação em Saneamento, Meio Ambiente e Recursos Hídricos da UFMG 
localizada em Minas Gerais, terceiro estado-federado mais importante em termos econômicos e industriais no Brasil, por meio do estudo das restrições e potencialidades de atuação de seu comitê, que foi instituído pelo Estado no ano de 1998, justamente 10 anos após a nova Constituição Federal do país ser promulgada.

Além disso, o comitê surgiu apenas 1 ano após a principal legislação brasileira sobre recursos hídricos ser oficial (Lei Federal no 9.433, de 1997) e 1 ano antes de da Política Estadual de Recursos Hídricos em Minas Gerais (Lei Estadual $n^{\circ}$ 13.199). Inclusive, a demora na formulação de uma lei nacional sobre o tema no Brasil acabou por fazer com que vários estados criassem suas próprias leis regionais (TORTAJADA, 2001), próximo ao que aconteceu no território mineiro.

Cabe ressaltar também que o Brasil tem como forma de governo o modelo de república federativa, que é dotado de 27 unidades administrativas e com 3 níveis e escopos distintos para as tomadas de decisões institucionais (municipal/local; estadual/regional; federal/nacional). Isso faz com que a gestão de recursos hídricos adquira uma complexidade organizacional que demanda maior conhecimento e aprimoramento de seus instrumentos de gerenciamento.

Mais, o estado-federado de Minas Gerais possui o maior número de municípios do país, 853, e somente a bacia hidrográfica do Rio das Velhas, objeto desta pesquisa, compreende 51 municípios distribuídos em seus $29.173 \mathrm{~km}^{2}$ de área de drenagem e com $801 \mathrm{~km}$ de extensão da calha principal do rio, o que significa a distância em linha reta entre o ponto mais distante da foz e esta (CBH VELHAS, 2014; CAMARGOS, 2005).

Nesse sentido este artigo visa estudar qual o alcance do papel do Comitê da Bacia Hidrográfica do Rio das Velhas (CBHRV, daqui por diante) na gestão de recursos de seu território de competência, assim como delimitar o limiar da existência de autonomia ou controle por parte do Estado em termos das decisões deste e da consolidação de um modelo participativo real. Parte-se do pressuposto de uma atuação ambígua do Estado, ora a concordar com a autonomia dos organismos de bacia, ora a controlá-los em suas práticas institucionais.

Consequentemente, as questões são levantadas por vários autores que tratam sobre o conceito de boa governança, considerado dentro desta pesquisa como um dos modelos de gestão 
possíveis de serem aplicados em um dado contexto institucional. Tal possuiria como característica a incorporação de determinados critérios, a depender das perspectivas de análise (tais como ROGERS e HALL (2003); WARNER (2007); MAYNTZ (2000) etc). As mesmas, de forma geral, buscam a formação e consolidação do gerenciamento democrático e participativo, mesmo que dentro de um cenário de mudanças e intervenções aos interesses estatais (SWYNGEDOUW, 2005). Salienta-se que os cenários de mudanças institucionais são recorrentes no caso brasileiro, com maior ou menor valorização de instâncias e processos participativos.

Nessa direção, o artigo busca identificar quais os elementos institucionais que o CBHRV traz enquanto modelo de boa governança a partir de alguns critérios que foram escolhidos por representarem possibilidades de explicação mais amplas e concatenadas com a proposta deste artigo. Nesse sentido, os critérios de participação, transparência e práticas foram os escolhidos para comporem um rol de avaliação do CBHRV, mas outros critérios tais como tipo de desenho institucional, historicidade, legitimidade, legalidade etc também poderiam fazer parte de uma análise de gestão institucional, mas possivelmente a gerar encaminhamentos diferentes do aqui é trabalhado.

Vale também destacar que o que é considerado como "ações diferenciadas" é o conjunto de intervenções que não são utilizadas usualmente em modelos de comitês de bacia hidrográfica, não sendo necessariamente inovações na gestão e mais assimilações, adaptações de modelos usuais de gestão hídrica (com exemplos a serem demonstrados adiante).

No caso específico do Brasil, o estudo da aplicação de princípios de governança é uma possibilidade para o aprimoramento do setor público e de suas decisões políticas e administrativas. Sendo um dos principais atores no cenário ambiental do século XXI, o país tem colocado, em vários de seus Estados-membros, arranjos institucionais participativos para a gestão hídrica, seja por meio de legislação mais abrangente para tal, seja pela instauração de arenas de planejamento, consulta ou deliberação coletiva. Tal como descrito, o Brasil possui um caráter federativo onde a gestão de recursos hídricos acontece por meio da unidade de planejamento e integração principal que é a bacia hidrográfica, inclusive com determinação legal para tanto (Lei $\mathrm{n}^{\circ}$ 9.433, de 1997).

A Figura 7.1, por exemplo, tenta expor uma estrutura mínima de atuação para o Sistema Nacional de Recursos Hídricos, o que não impede, em termos jurídicos ou administrativos, 
outros tipos de desenhos institucionais. Ao contrário, a proposta prevista na legislação pertinente ao sistema de gestão hídrica do país é o de justamente tentar incluir instâncias que sejam próximas aos locais de atuação dos organismos de bacia - o que existe é uma matriz institucional que permite, legal e administrativamente, várias possibilidades.

Em sua forma tradicional, como visto na Figura 7.1, tem-se:

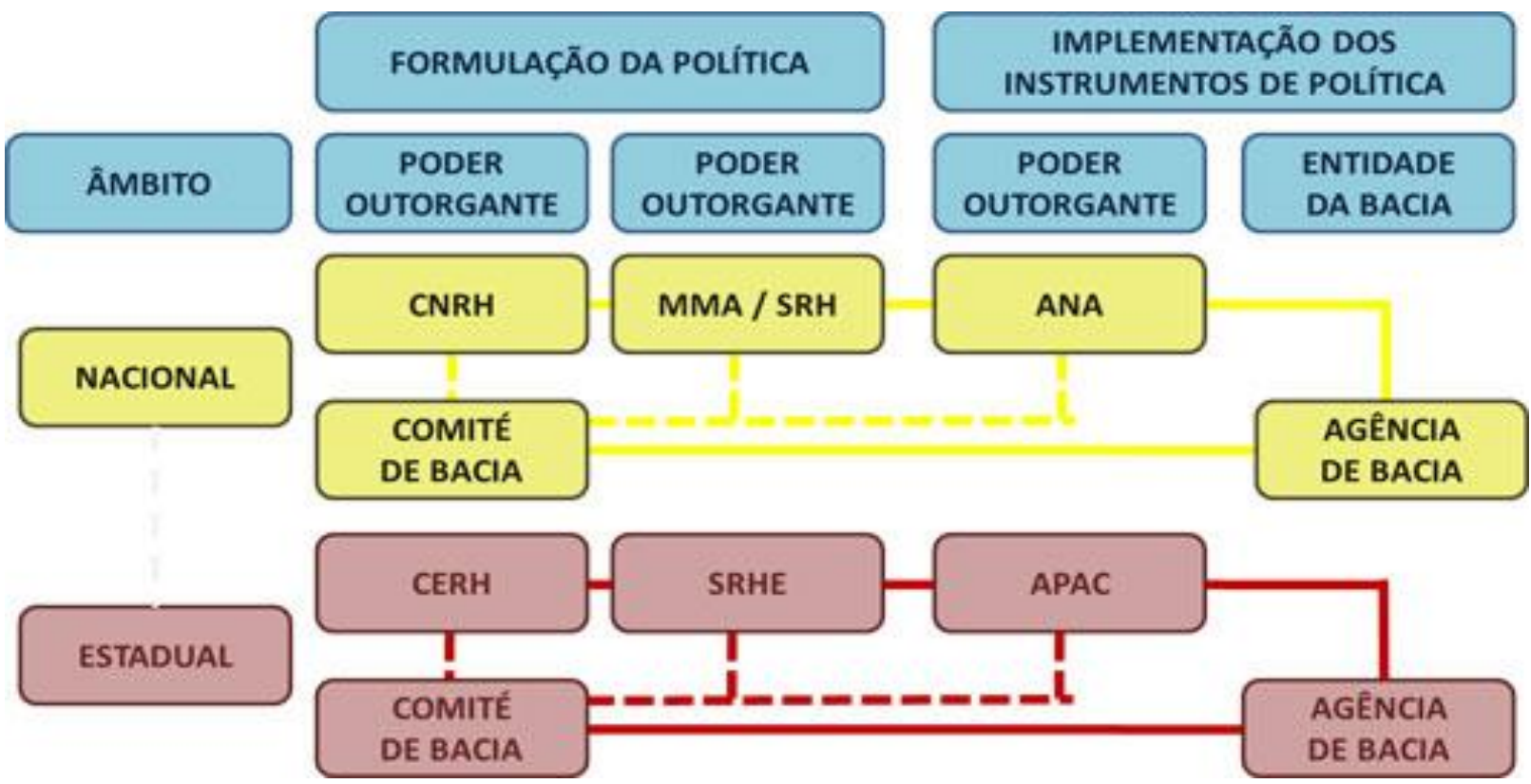

Figura 7.1: Estrutura mínima proposta para o Sistema Nacional de Recursos Hídricos

Fonte: ANA (2012)

Dentre suas instituições componentes estão:

1) Organismos Colegiados: Comitês de Bacia Hidrográfica (CBH); Conselhos Estaduais de Recursos Hídricos (CERH); Conselho Nacional de Recursos Hídricos (CNRH). Responsáveis pelas discussões e resoluções de conflitos ao nível das bacias;

2) Administração Direta: Secretarias de Estado; Ministério do Meio Ambiente (MMA)/Secretaria Nacional de Recursos Hídricos (SRH). Responsáveis pelo gerenciamento institucional e estrutural da Política Nacional de Recursos Hídricos. 
3) Poder Outorgante: Entidades Estaduais (no caso de Minas Gerais, o Instituto de Gestão das Águas - IGAM); Agência Nacional de Águas (ANA) ${ }^{71}$. Responsáveis pela aplicação dos instrumentos de gestão ao nível administrativo.

4) Entidade de Bacia: Agências de Bacia. Responsáveis por executar e ajudar administrativa e juridicamente aos Organismos Colegiados.

E nessa estrutura é que estão os Comitês de Bacia Hidrográfica $(\mathrm{CBH})$ como um dos principais exemplos possíveis dessa tendência de ampliação da democracia e da participação coletiva multiníveis, mesmo que ainda em consolidação e em prática não majoritária de aplicação em todo o território, devido às suas inerentes características. Normalmente o modelo de participação é tripartite, de forma que cada setor setor seja representado, mas sem a prevalência de um sobre os outros.

Já no modelo quadripartite do CBHRV, a divisão entre poder público municipal e estadual foi estipulada para possibilitar maior participação ao poder local, que possui lógica de atuação diferente da regional.

O referido objeto (Comitê da Bacia Hidrográfica do Rio das Velhas, ou CBHRV) foi selecionado na medida em que propicia o estudo de um organismo de bacia hidrográfica que se encontra em atuação há mais de 15 anos, sendo assim um dos mais antigos do país, como também por ser aquela bacia à qual pertence a capital do estado-federado em questão, Belo Horizonte. Isto lhe confere caráter particularizado no contexto da governança a ser exercida, uma vez que, conjuntamente com a bacia hidrográfica do Rio Paraopeba, que lhe é vizinha, tem-se a mais rica e populosa região metropolitana do estado de Minas Gerais. Mais ainda, dos 34 municípios que a compõem, 20 possuem território na bacia do Rio das Velhas e se encontram representados no CBHRV.

O comitê em si, em termos de sua composição, possui 28 membros titulares (e 28 suplentes) que, em um sistema quadripartite, estão representados em igual número de 07 membros por segmento (sociedade civil, usuários de água, poder público estadual, poder público municipal). Eles são eleitos para um mandato de 04 anos, passível de reeleição, e com a

\footnotetext{
71 A legislação pertinente à ANA é a Lei Federal n 9.984/00, e sobre o IGAM, o Decreto Federal $41.578 / 01$.
}

Programa de Pós-graduação em Saneamento, Meio Ambiente e Recursos Hídricos da UFMG 
realização de reuniões ordinárias e/ou extraordinárias (denominadas de "plenárias") para a definição de suas ações a cada ano.

Além disso, existem 04 Câmaras Técnicas (CTs) onde membros e não-membros podem interagir sobre aspectos específicos da gestão do comitê: (1) Planejamento, Projetos e Controle; 2) Educação, Mobilização e Comunicação; 3) Institucional Legal; 4) Outorga e Cobrança). A eleição, deve-se destacar, é parte de um processo de chamada pública, onde as instituições são selecionadas a partir de critérios técnicos-administrativos (vinculação com a temática ambiental e hídrica; histórico de participação em movimentos sociais e ambientais; representatividade comprovada em segmento próprio etc). Após esta seleção prévia, dão-se os processos de interação entre os atores e suas instituições para a definição dos nomes que irão compor os níveis de decisão estabelecidos (presidência, vice-presidência, diretoria colegiada, câmaras técnicas).

A discussão proposta pretende evidenciar lacunas existentes nos processos de tomada de decisão e de definição da agenda institucional em relação à bacia hidrográfica referida que, mesmo sendo considerada uma das mais importantes do Estado de Minas Gerais, ainda demanda maior conhecimento de seus processos institucionais de governança. Pretende-se aqui, igualmente, relatar e avaliar as transformações institucionais na gestão dos recursos hídricos na bacia pesquisada e de como a governança foi sendo gradativamente colocada na agenda pública pelo Estado (SWYNGEDOUW, 2005; GREEN, 2007).

O enfoque priorizado dentro do escopo da temática da boa governança da água é o da articulação dos atores institucionais para processos de gestão democrática e participativa. Mais ainda, a boa governança e suas argumentações teóricas podem cooperar para o entendimento, neste trabalho, para o entendimento sobre os principais problemas que afetam a bacia hidrográfica do Rio das Velhas, a partir dos dados coletados em campo aliados à análise documental e histórica proposta (MINAYO, 2012).

Cabe salientar que o termo governança possui várias leituras, nem sempre congruentes entre si e que demonstram a diversidade de possibilidades que, conceitualmente, o termo absorve (GREEN, 2007). Nessa direção, vale destacar as contribuições de DOUROJEANNI e JOURAVLEV (2002) e de TUCCI (2001) - de tendências mais convencionais - como também de TORTAJADA (2001), CASTRO (2007) ou SWYNGEDOUW (2005) - de 
tendências mais críticas, permitem revelar que a gestão enquanto processo de gestão pode criar ambientes e resultados diferentes entre si.

Outrossim, a própria proposta de gestão a partir da bacia hidrográfica, mesmo que considerada como um avanço administrativo ainda é bastante controversa em sua aplicação (ABERS, 2010, SOARES, 2008; THEODORO; MARQUES, 2014; TORTAJADA, 2001). Em uma bacia de proporção tão extensa e de níveis distintos de estrutura física, econômica e social (CAMARGOS, 2005; THEODORO; MARQUES, 2014) como se tem no Rio das Velhas, práticas de gestão integrada também são demandas para soluções complexas que envolvem direitos difusos como os hídricos (GREEN, 2007; ROGERS e HALL, 2005; ABERS 2010; ABERS e KECK, 2013).

Para MAYNTZ (2000) o termo pode ser compreendido como denominação de forma de direcionamento governamental que tem a ambição de ser associado a um conhecimento dos interesses e valores das pessoas (RICHARD e RIEU,2008). Na atualidade, caracterizaria novos estilos de governo que sejam distintos da atuação hierárquica tradicional, com a incorporação maior de redes de decisão mista entre público e privado, assim como de atores não governamentais da sociedade.

Desta forma, houve uma maior abrangência de significados do termo durante as últimas décadas, desde sua caracterização paradigmática fundamental de elaboração e implementação de políticas públicas até a inclusão de diversos aspectos (perspectiva bottom-up; redes públicas-privadas, déficit de democracia etc), o que colocou o termo em situações inclusive conflitantes e que foram derivadas das inclinações conceituais de seus autores (GREEN, 2007).

Para ROGERS e HALL (2003), por exemplo, a "governança" pode ser entendida como a alocação e regulação políticas entre sociedade e governos, por meio de mediação via valores, normas e, quando possível, legislações. Considera que as redes de influência, atividades domésticas e setores de mercado e sociedade civil são aspectos relevantes para a governança.

Assim, uma demonstração da nova forma de atuação dos governos passaria pela incorporação de novos atores vindos do mercado e da sociedade civil como possibilidade de recuperação da confiança da atuação institucional governamental e do estabelecimento de um novo patamar 
de democracia participativa, com mais espaços para a construção de diálogos institucionais (SOARES, 2008; WARNER, 2007; ABERS, 2010; CUNHA; THEODORO, 2014).

Outrossim, o conceito de governança que se encontra na literatura dominante idealiza um rol de interações entre governo-mercado-sociedade civil que se tornou central nas discussões das políticas públicas ("tri-partite partnership") - também presente em Cunha e Theodoro (2014) e Theodoro (2002) - porém Castro (2007) alerta que esse balanço de forças necessitaria ser examinado com maior rigor, pois correria o risco de não explicar todos os complexos arranjos institucionais existentes e seus conceitos.

Assim também indica Swyngedouw (2005) em que a "composição tripartite" não é igualitária, nem participativa, nem democrática como se supõe. O que indica que não basta que se tenha uma divisão igualitária de representação formal-institucional para que um processo de gestão democrática, descentralizada e participativa ocorra realmente. E para Richard e Rieu (2008), o termo "governança" se impôs a partir dos anos 80-90 como um símbolo de uma nova modernidade dentro dos modos de ação das políticas públicas, e foi sendo paulatinamente incorporado pelos economistas, até alcançar a expressão de "boa governança". Esta foi rapidamente utilizada por instituições financeiras internacionais como sinônimo de boa administração pública (em termos de estratégias e implementação de ações), principalmente em países sujeitos a programas de ajustamento estrutural, como o Brasil.

Sendo assim, o Banco Mundial (como depois outros organismos tais como PNUD, FMI, OCDE, dentre outros) foi a primeira instituição internacional a utilizar o termo "governança" como “... o modo em que o poder é exercido no gerenciamento econômico e dos recursos sociais para o desenvolvimento de um país.” - Banco Mundial (1992, p. 1). Ao se traduzir estas estruturas para o desenvolvimento institucional que ocorreu nas políticas públicas de água do Estado brasileiro e em Minas Gerais especialmente, nota-se que houve o envolvimento das mesmas em diversas fases da consolidação da gestão. A grosso modo a situação atual é a prevista em lei, porém deve ser entendida como resultado de um longo processo de debate para a construção de um modelo de governança ao setor hídrico.

Mais ainda, houve um importante papel de mobilização inicial alavancado pelo Estado para a criação e estruturação dos CBHs. Essa importância até hoje existe nos comitês brasileiros e faz com que muitas ações de iniciativas dos setores sociais sejam coadjuvantes ou dependentes dessa trajetória institucional estatal inicial.

Programa de Pós-graduação em Saneamento, Meio Ambiente e Recursos Hídricos da UFMG 
E a partir das discussões anteriormente citadas e na falta de consenso conceitual existente (GREEN, 2007), "boa governança" utilizada neste trabalho como uma das formas de gestão possíveis, porém sendo aquela em que se tem um modelo de gestão com maior democracia e participação dos atores envolvidos.

A escolha por esta definição se dá pela explicação de que os grupos diversos interagem para (tentar) criar um ambiente consensual mínimo para ações democráticas e participativas. O que a gestão democrática e participativa hídrica poderia exprimir a partir dessa noção seria da interdependência entre os atores públicos e privados, da interação constante entre diferentes para a criação de consensos coletivos para situações de gestão diversas frente às ações estatais que por vez mais controlam do que criam autonomias de ação (SWYNGEDOUW, 2005).

Assim, existe um reconhecimento de que têm havido avanços na consolidação de um modelo mais participativo e democrático de gestão institucional, mas que há de se ter também certa maturidade de se entender que o sistema para tal caminha ainda de forma lenta e que tem por base um arcabouço jurídico e institucional muito recente (tal como a criação da agência reguladora, a Agência Nacional de Águas (ANA), que é de 2000, ou o Instituto Mineiro de Gestão das Águas (IGAM), que é de 1997) - vide Figura 7.2 (a). Em realidade, todo o processo de institucionalização da gestão de recursos hídricos é relativamente nova no país, a ver:

Programa de Pós-graduação em Saneamento, Meio Ambiente e Recursos Hídricos da UFMG 

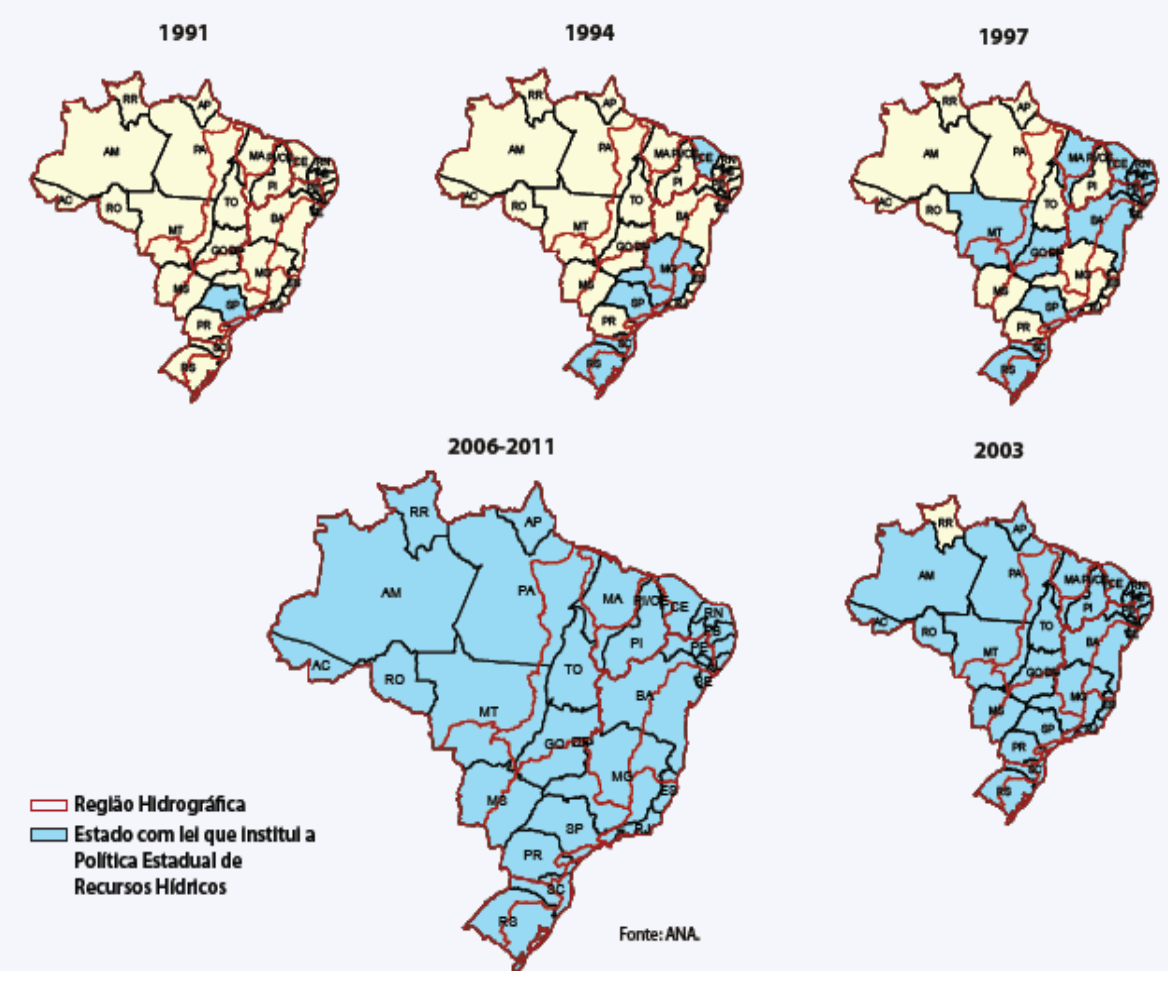

(a)
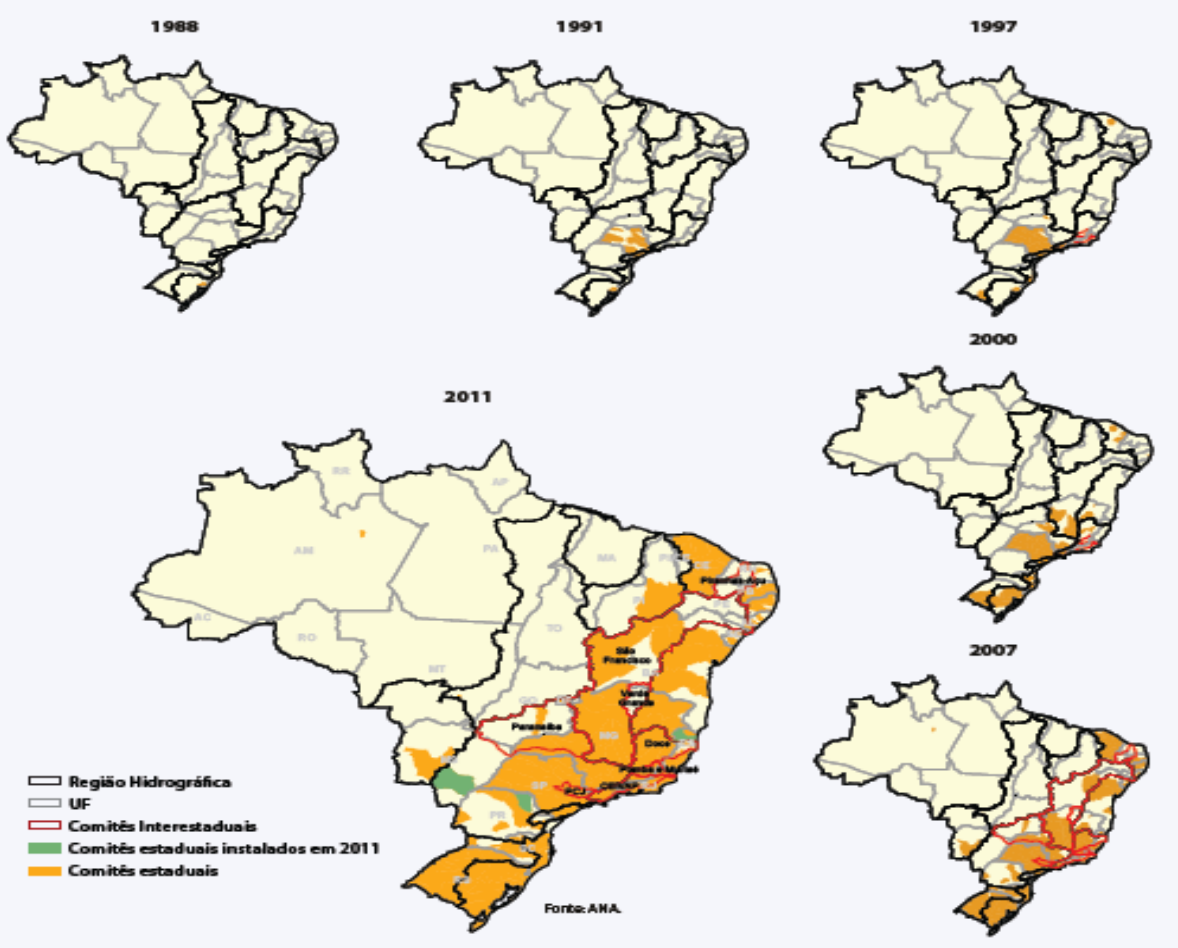

(b)

Figura 7.2: Avanço da institucionalização das políticas públicas estaduais de recursos hídricos (a) e da implementação de comitês de bacia hidrográfica no Brasil (b)

Fonte: ANA (2012)

Programa de Pós-graduação em Saneamento, Meio Ambiente e Recursos Hídricos da UFMG 


\subsection{MÉTODOS}

Para o desenvolvimento da pesquisa foi feita uma análise triangular que envolve tanto o aspecto teórico ("análise documental"), como de campo ("observação participante") e de entrevistas individuais ("análise de conteúdo"), o que é considerado dentro do conceito de "triangulação de métodos" já discutido por GOLAFSHANI (2003), FLICK (2009) e, principalmente, MINAYO et al (2005), de forma a dar ao fenômeno investigado, mais capacidade de ser explicável, confiável e validado.

Essa conjunção de métodos e técnicas de pesquisa foi escolhida na medida em que, atualmente, já se percebe na pesquisa qualitativa uma solidez suficiente para ser empregada como instrumento de pesquisas em geral e, em particular, por se adequar ao estudo de contextos complexos (FLICK, 2009). Mesmo que tradicionalmente as pesquisas se construam muitas vezes apenas nos elementos quantitativos de análise, a interação entre técnicas tem sido crescentemente adotada (MINAYO, 2012; MINAYO et al, 2005; THEODORO e MARQUES, 2014) para tentar explicar, mais do que descrever, processos institucionais.

Destaca-se assim que a principal fonte de coleta e análise de dados desta pesquisa está relacionada com 25 entrevistas realizadas com indivíduos de destaque tanto na gestão de recursos hídricos quanto nas análises desta, sendo aqui considerados como lideranças em suas áreas de atuação e com relações diretas ou indiretas com o CBHRV. Buscou-se refletir na escolha dos entrevistados a representatividade quatripartite do comitê pela participação de indivíduos pertencentes a vários grupos de interesses, além de elementos externos ao mesmo mas que dele têm conhecimento continuado.

Observados esses critérios, os entrevistados provêm dos seguintes segmentos: Usuários (5); Sociedade Civil (6); Poder Público Municipal (2); Poder Público Estadual (1); e de Instituições/Organizações (8) - tais como a agência de água do Rio das Velhas, denominada de "AGB Peixe Vivo" e universidades. Utilizou-se um roteiro padrão de entrevista aplicado a cada entrevistado, requerendo um tempo de entrevista da ordem de 50-60 minutos. O roteiro foi composto por 18 perguntas semi-estruturadas abertas sobre 8 diferentes categorias analíticas, a saber: uso e ocupação do solo; qualidade de água; quantidade de água; bioindicadores; dimensão institucional; dimensão integradora; dimensão legal; dimensão econômica-financeira. Salienta-se que neste artigo encontram contempladas as análises dos

Programa de Pós-graduação em Saneamento, Meio Ambiente e Recursos Hídricos da UFMG 
temas das dimensões institucional, integradora, legal e econômica-financeira, com ênfase sobre a primeira.

Para a análise de dados, empregou-se a "análise de conteúdo" (BARDIN, 1994), em que se tenta identificar argumentações diretas e indiretas dos discursos dos atores envolvidos, de maneira a se formar um panorama mais abrangente (e ao mesmo tempo, mais próximo) sobre o objeto escolhido. O que se esperava com as entrevistas era destacar quais as principais restrições e possibilidades de melhorias institucionais nos processos de gestão de recursos hídricos no Rio das Velhas, para possibilitar uma análise longitudinal dos mesmos (GREEN, 2007), principalmente em termos das 4 dimensões de pesquisa anteriormente descritas. Esperava-se também a identificação das nuances e dos bastidores das tomadas de decisões e das ações políticas dos diversos grupos representados no CBHRV.

Isto permitiu se verificar as "presenças" e "ausências" nos relatos que, com a utilização de outras técnicas, de forma isolada, seriam mais difíceis de serem detectadas, uma vez que aqui se admite a concepção da análise qualitativa como algo mais do que classificação de opiniões de informantes e sim como descoberta de seus códigos sociais (MINAYO, 2012). Também como suportes metodológicos para a pesquisa foram utilizadas as principais documentações referentes ao desenvolvimento das políticas públicas vinculadas à gestão da bacia hidrográfica do Rio das Velhas, tais como legislações, deliberações normativas e afins, assim como os dados levantados em campo ("observação participante"), de forma não sistemática mas decorrente da experiência vivenciada pelo primeiro autor deste trabalho no decorrer de vários anos como membro do próprio comitê e do Comitê da Bacia Hidrográfica do Rio São Francisco (CBHSF), uma vez que o Rio das Velhas é tributário deste.

Essa abordagem permitiu uma visão mais completa sobre as restrições e possibilidades de atuação do comitê referido, assim como sobre o sistema de gestão de forma geral, pois tanto o meio físico (uso e ocupação do solo), quanto biótico (quantidade e qualidade de água, bioindicadores), quanto antrópico (dimensões de atuação do CBHRV - institucional; integradora; legal; econômica-financeira), foram incluídos e discutidos. As análises de conteúdo possibilitaram a identificação de lacunas institucionais, uma das hipóteses da pesquisa, além de demonstrar que o método qualitativo é pertinente, entre outras coisas, porque sobre o tema em questão há pouco o que se quantificar e mais a se explicar em termos 
dos critérios empregados sobre participação, transparência e práticas diferenciadas, com vistas a processos mais democráticos de gestão.

Tais temas, à luz de uma análise de conteúdo, combinada com a interseção de dados documentais, de campo e de interações face a face, foram primordiais para que os resultados a seguir fossem conseguidos, frutos do que MINAYO (IDEM) chama da união entre “...a teoria da abordagem (o método), os instrumentos de operacionalização do conhecimento (as técnicas) e a criatividade do pesquisador (sua experiência, sua capacidade pessoal e sua sensibilidade").

\subsection{RESULTADOS E DISCUSSÃO}

O CBHRV possui um arranjo institucional, administrativo demográfico e jurídico que teve na sua base a proposta de uma gestão descentralizada, democrática, participativa e integradora. $\mathrm{O}$ que se percebeu dos elementos avaliados é que os determinantes da criação institucional deste comitê teriam de ser entendidos, no mínimo, em seu caráter contextual.

Como vimos, o conceito de boa governança que orientou a concepção do comitê não surgiu por um acaso mas sim inserido nas políticas internacionais de agências multilaterais que determinaram organizações mínimas de suposta participação social democrática (BANCO MUNDIAL, 1992; ROGERS e HALL, 2003; GREEN, 2007) como condicionalidades para o financiamento de empreendimentos variados de infraestrutura, sendo a área de recursos hídricos um exemplo tradicional de demanda desse tipo de apoio financeiro.

Ao mesmo tempo, o Brasil se encontrava a partir de meados dos anos 1980 em um processo de redemocratização de suas instituições e tal momento também deve ser considerado em uma análise longitudinal e organizacional mais ampla (que leve em conta as transformações institucionais de longo prazo).

O período resultou em novos arranjos políticos e administrativos de decisão e de implantação de políticas públicas. O que indica que existiram fatores endógenos e exógenos que se complementaram para que a criação de organismos de bacia, no caso do Brasil e de Minas Gerais, fosse realizada. 
Destaca-se que o comitê é uma representação desse contexto em que o próprio Estado (anteriormente um centralizador das decisões) foi o principal incentivador da formação do CBHRV, com a proposta, inclusive, de autonomia para a realização de suas funções (THEODORO, 2002; THEODORO; MARQUES, 2014, ABERS, 2010). O modelo de comitê, de base consultiva e deliberativa, com ampla participação pública e privada, dentro de processos abertos de acesso e saída de seus membros, foi uma característica explicitada desde sua gênese (CAMARGOS, 2005; GOULART, 2005; PROJETO MANUELZÃO, 2012; LISBOA, 2012), dentro da pretensão de se estabelecer como uma proposta muito próxima da colocada por SWYNGEDOUW (2005) em termos de uma "governança-além-do-Estado".

Contudo, o conjunto de dados de campo, juntamente com as entrevistas com lideranças, indicou que a implementação desse cenário de "multi arenas de interação democrática" (WARNER, 2007) foi fortemente questionada. Para alguns, o modelo saiu do papel apenas parcialmente e ainda tem muito o que ser debatido, aprimorado e implantado. Uma das questões consideradas é a representatividade institucional no âmbito do comitê; por exemplo, há maior concentração de subcomitês na parte mais urbanizada da bacia - vide Figura 7.2 (b); as reuniões para tomadas de decisões geralmente são realizadas na capital do Estado, Belo Horizonte, o que pode ser um fator limitante para a participação de representantes de entidades localizadas distantes da sede do Comitê.

Outros fatores mais sutis relacionados com o equilíbrio de participação e de composição da agenda do Comitê referem-se, por exemplo, à diversidade de ocupação da bacia e de uso dos recursos hídricos e de outros recursos naturais (Figura 7.3). A composição da agenda de questões a debater e decidir e a organização dos os processos de participação democrática dependem do contexto de cada região na bacia. Mais ainda, foi verificado que nos últimos anos, a estrutura institucional para a gestão de recursos hídricos em Minas Gerais como um todo e no CBHRV em especial foi muito dilapidada e colocou os atores sociais em rotas de colisão.

O caso mais emblemático, a título de ilustração, foi o choque de posições entre Estado e comitê em relação à organização da equipe de mobilização deste último e que já tinha atuação em toda a bacia hidrográfica há vários anos. Isso colocou a agência de águas (denominada Agência de Bacia Peixe Vivo - AGBPV) em conflito com o CBHRV e com o Instituto Mineiro de Gestão das Águas (IGAM) em várias ocasiões e gerou um período turbulento e de 
impasses na gestão da bacia, sendo considerado por muitos como uma crise institucional real ao final do ano de 2012 (LISBOA, 2012).

Naquele ano, por exemplo, devido às leituras antagônicas sobre a legalidade ou não da existência de equipes de mobilização social para atuação na bacia do Rio das Velhas, assim como que o CBHRV possuísse sede própria, o Estado se colocou fortemente contra ao modelo existente e demandou um novo desenho operacional sobre o assunto. Isso gerou desgastes constantes entre as partes até a normalização da situação, com a restauração das ações de mobilização social por meio de equipe selecionada por chamada pública.

Explica-se: o papel das equipes de mobilização era e é o de fazer a interação entre os atores sociais da bacia hidrográfica de forma a se consolidar o processo de gestão democrática, participativa e descentralizada. Porém, o financiamento da mesma não estava, segundo o Estado, de acordo com as determinações legais da Lei $n^{\circ}$ 9.433/97 e, até o ajustamento legal e administrativo, a equipe de mobilização foi dissolvida e eventualmente restabelecida, em um processo que demorou quase um ano para ser finalizado. Enquanto para Estado e AGBPV era uma questão de ajustamento jurídico e administrativo, para o CBHRV era uma questão de continuidade de uma política de gestão participativa que foi naquele momento interrompida. Consequentemente o conflito se deu entre os agentes.

Talvez aí se encontre um tema muito frequente no conteúdo das entrevistas, o fato de que tanto a agência quanto o comitê são percebidos por muitos dos entrevistados como menos autônomas do que o que foi pensado inicialmente (tal como os modelos da França ${ }^{72}$ e da Espanha $^{73}$ ). No fim das contas, a agência tem sido percebida menos como o órgão executor das demandas do comitê, como previsto em legislação, e mais como um braço institucional de intervenção do Estado, e não além dele, como sugere SWYNGEDOUW (2005).

Isso talvez se deva ao fato de que a AGBPV atua, administrativamente, por processos de licitação (principalmente pela Lei Federal 8.666/93), que trariam isonomia entre os atores sociais e institucionais envolvidos. Mas, na prática, são vistos como procedimentos de retardo às demandas colocadas no CBHRV e considerados como "cartoriais". Mais, existem decisões já tomadas, mas que são consideradas de tardia implantação pelos membros do CBHRV, tais

\footnotetext{
$72 \quad$ FRANCE (2014).

73 SWYNGEDOUW (2013).
}

Programa de Pós-graduação em Saneamento, Meio Ambiente e Recursos Hídricos da UFMG 
como a realização de planos diretores de saneamento ou projetos hidroambientais, ambos ao nível municipal ${ }^{74}$.

Outro problema constatado é que a maioria destes processos decisórios acontece em termos de considerações políticas e/ou econômicas de curto prazo que desmerecem arranjos sociais que são inerentemente de longo prazo (integração institucional, participação e democratização das arenas consultivas etc). $\mathrm{O}$ caso das dificuldades para a instalação de subcomitês realmente operacionais no território da bacia é um exemplo a ser considerado, visto que muitas vezes não há um suporte administrativo para que os mesmos atuem.

Na mesma direção, é possível se identificar que o foco da emergente cultura da água é sobre seu compartilhamento, descentralizado, entre atores sociais assimétricos em poder, localização e recursos, o que aumenta a demanda pela integração via modelos de cooperação social e institucional. O fato é que, tal como alerta ABERS et al (2010), a própria descentralização atua como uma nova abordagem nas políticas públicas e que deveria ser também um fator considerado na construção da agenda política para ir além das ações tradicionais estatais (SWYNGEDOUW, 2005). Os próprios comitês, por exemplo, podem adquirir sua justificativa de permanência se, por um lado, representam novas alternativas (MOULAERT et al., 2005) aos processos tradicionais de voz (representação) e voto (deliberação) e demonstrarem capacidade de interagir em termos de micro e macro políticas.

Com este cenário, a governança hídrica alcança um novo patamar ao tentar ser uma abordagem em que a integração na gestão da água possa ocorrer mesmo que por meio das resistências iniciais institucionais ou sociais (visto que redimensiona deveres, direitos e, principalmente, poder decisório - GOOCH e HUITEMA (2004)).

Estas resistências precisariam ser compreendidas por uma visão holística da gestão para que se tenha um planejamento/execução compatível para ações de nível estratégico e local conjuntamente que superem (UNESCO, 2006): inadequada consciência pública ou despolitização das discussões e deliberações (WESTER e MERREY, 2005); envolvimento limitado das comunidades e setores privados para planejamento e orçamento; falta de recursos para operar (KAUFMANN et al. 1999); fragmentação institucional (THEODORO, 2002);

74 Sobre Planos Municipais de Saneamento, ver Pereira e Heller (2015).

Programa de Pós-graduação em Saneamento, Meio Ambiente e Recursos Hídricos da UFMG 
inadequação de políticas públicas integradas (MACIEL, 2008); visão da água apenas como recurso (CASTRO, 2007); outras situações particulares.

E o aumento crescente do interesse pela gestão na referida bacia acontece tanto pela gravidade ambiental que tem vinculação ao tema, como também pelo aporte financeiro que está mais disponível atualmente para projetos e serviços ambientais. Nesse sentido vale destacar que, para os especialistas ouvidos, há um grande disparate entre os recursos alocados para a gestão (na ordem de 15 milhões de dólares anuais, de acordo com o Plano Plurianual de Aplicação da AGBPV) e os valores reais necessários à recuperação ambiental da bacia (que já recebeu mais de 600 milhões de dólares de investimentos para tal até 2013 e que tem planejamento de investimento de mais 250 milhões de dólares até 2015 - ABES, 2014).

Mas, deve-se esclarecer que não é esperado que os recursos oriundos da cobrança por uso de recursos hídricos sejam capazes de suprir todas as necessidades de investimentos na bacia, mas sim que sejam compreendidos como potenciais catalizadores para posterior mobilização de outros investimentos. Por exemplo, e tal como relatado em várias entrevistas, investimentos na realização de Planos Diretores de Recursos Hídricos, Planos Municipais de Saneamento, Planos Diretores Municipais etc podem efetivar adiante a captação de recursos destinados ao saneamento, meio ambiente e recursos hídricos de forma mais ampla e eficiente do que até agora tem sido feito.

Porém, este processo de entendimento por parte do Estado e dos membros do CBHRV da complexidade em que se encontra a gestão da bacia e de como poderiam efetivamente participar dela ainda se encontra em consolidação. Ao mesmo tempo, há um reconhecimento de que, de forma geral, houve um aumento na participação dos atores sociais, inclusive ao nível municipal, o que foi, inclusive, um dos principais objetivos do comitê nos últimos anos - vide Figura 7.4 .

O que foi relatado de forma recorrente é que tal aproximação se deveu muito mais aos interesses vinculados com as possibilidades de captação de recursos oriundos da cobrança por uso dos recursos hídricos (prevista na Lei Federal 9.433/97) para os municípios do que por participar realmente da gestão - provavelmente se encontra aí mais um exemplo da influência da ação estatal no processo de mobilização institucional da gestão hídrica ao direcionar o incremento da ação municipal local no comitê. Porquê mesmo que o recurso da cobrança não 
venha do Estado, ele é um importante ator institucional para a definição dos critérios da aplicação dos recursos nos municípios.

Sendo esse um fenômeno relativamente novo segundo os entrevistados, tal desconfiança existe e apenas o tempo poderá demonstrar sua extensão. De acordo com o que foi pesquisado, o discurso é que a participação no CBHRV tem sido pouco a pouco melhorada em seu sentido qualitativo e deliberativo. Assim, as pessoas e suas instituições têm demonstrado mais preparo para, de verdade, participar do planejamento e execução de ações e tentar vencer o "déficit democrático" (SWYNGEDOUW, 2005) presente em modelos de gestão democrática e participativa.

A Figura 7.3 e a Figura 7.4, por exemplo, demonstram a intenção de que, via unidades de planejamento e de subcomitês, seja ampliada a capilaridade de atuação administrativa e política ao longo da bacia hidrográfica. 


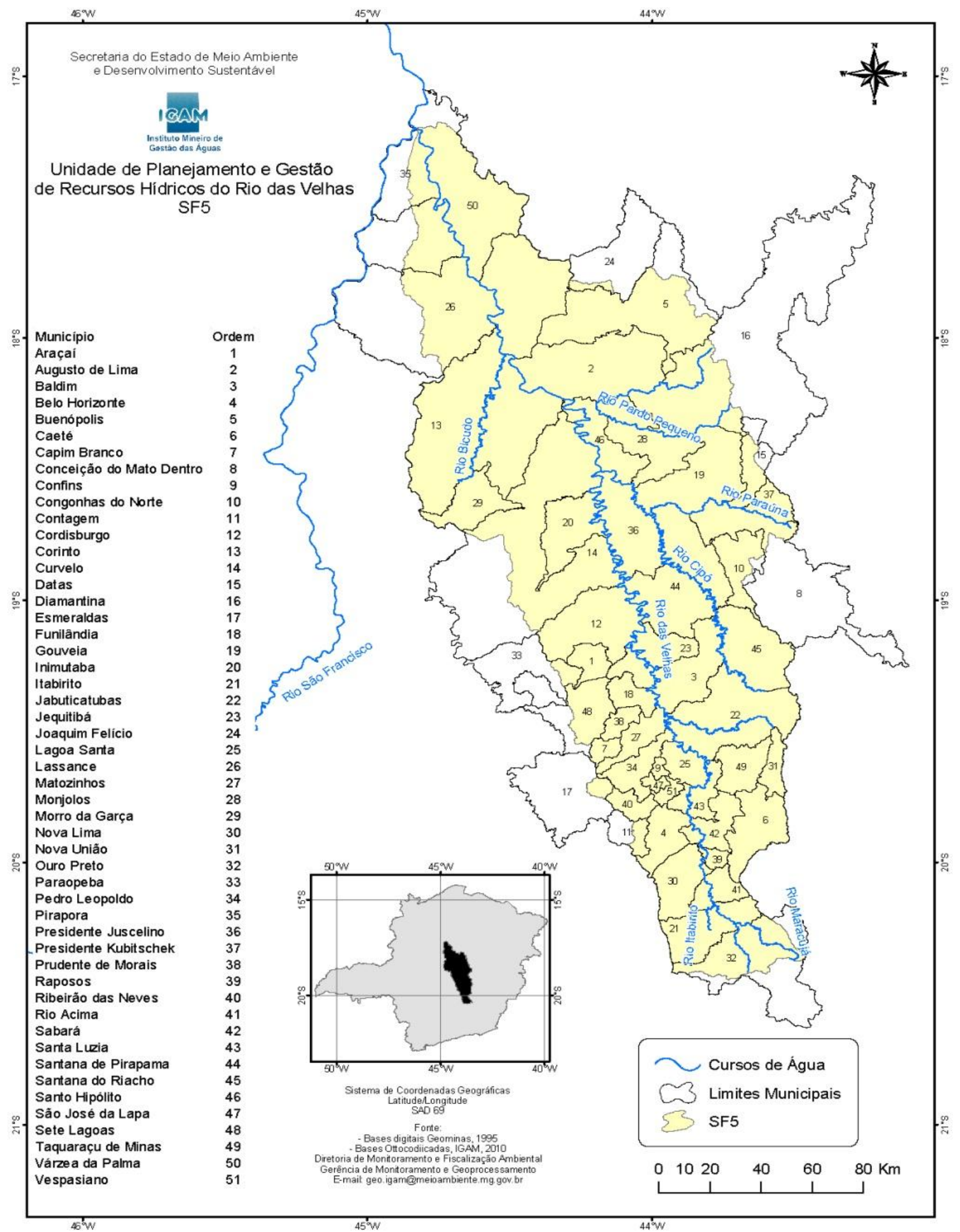

Figura 7.3: Unidades de Planejamento e Gestão de Recursos Hídricos

Fontes: www.igam.gov.br e www.cbhvelhas.org.br/index.php/module-positions

Programa de Pós-graduação em Saneamento, Meio Ambiente e Recursos Hídricos da UFMG 


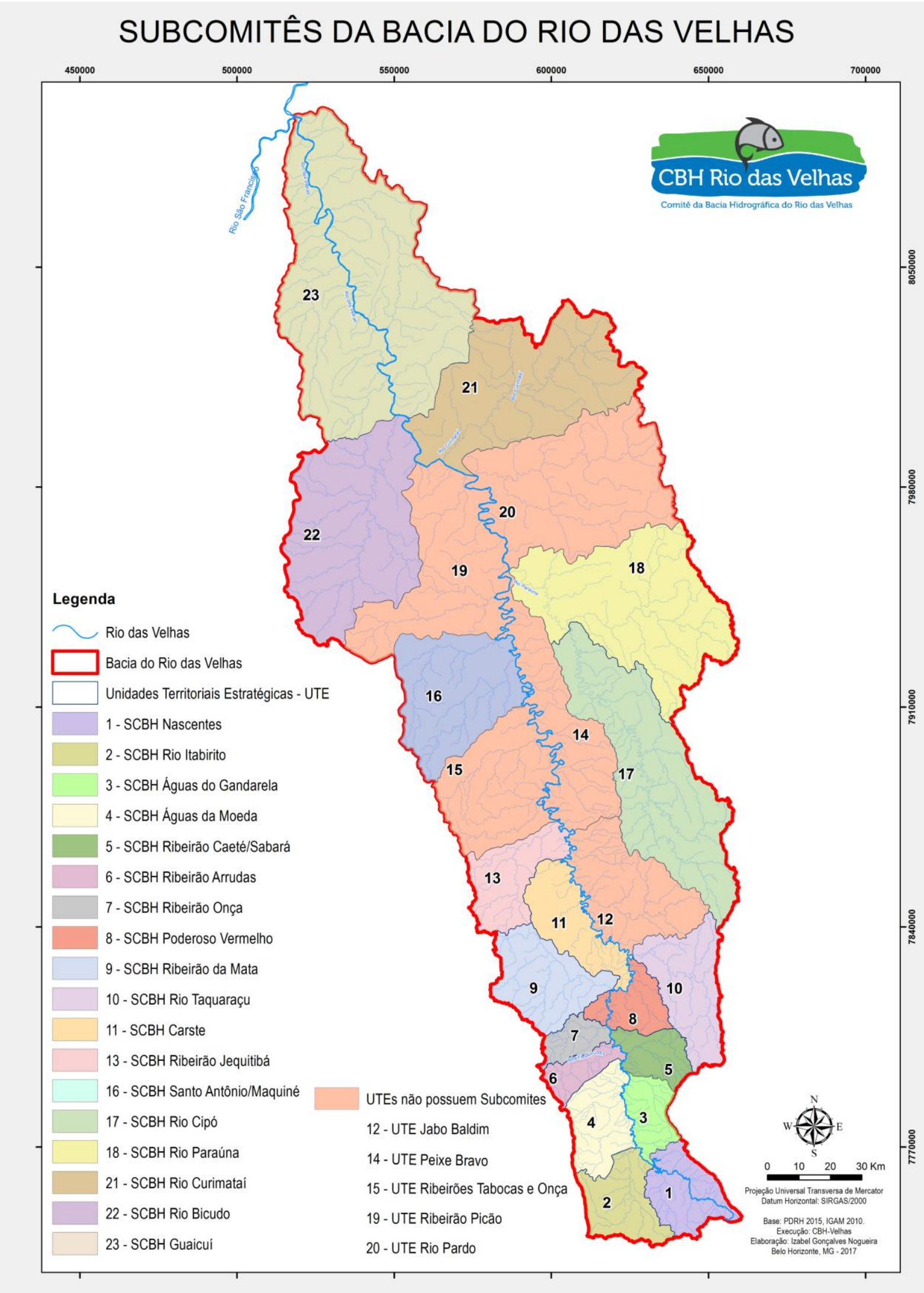

Figura 7.4: Subcomitês da bacia hidrográfica do Rio das Velhas (2017) Fontes: CBHRV (2017) 
Todavia, ao mesmo tempo as entrevistas mostraram que o comitê ainda precisa melhorar mais em tal aspecto para se aperfeiçoar; precisaria incorporar e refletir mais os movimentos sociais e ser capaz de criar interação institucional. Tal fato relembra muito as discussões oriundas de ARNSTEIN (1969) e também GOOCH e HUITEMA (2004) sobre os processos gradativos de participação. Seria necessária a implementação de um processo contínuo de "planejamento estratégico"; "implementação e gerenciamento"; "aprendizagem e adaptação" (WARNER, 2007) para que os CBHs passem a gerar novos ambientes para tais conversações, de maneira mais constante. Até porquê os sistemas (sociais, administrativos, econômicos, etc) são complexos e não haveria como todos os stakeholders participarem nem mensurarem todos os aspectos de governança envolvidos.

Foi identificada também no conteúdo das entrevistas a visão de que os órgãos gestores não atuam na mobilização de forma adequada para que o conceito de gestão democrática, descentralizada e integrada se torne realidade. O processo de consolidação da participação social no comitê pesquisado ainda é longo e frágil frente à estrutura e interesse de ação estatal, que muda suas ações para manter seu nível de controle, visto que é, provavelmente, o principal ator na gestão institucional (SWYNGEDOUW, 2005).

Da mesma forma, as organizações atualmente refletem as interações interpessoais de seus constituintes, o que demanda no processo de construção da boa governança institucional que lideranças sejam formadas e/ou consolidadas para se evitar que os processos sociais sejam interrompidos (WARNER, 2007). No estudo de caso do CBHRV, por exemplo, identificaram-se na pesquisa de campo e nas entrevistas as dificuldades em se estabelecer novas lideranças para a gestão institucional e local dos recursos hídricos. Cabe destacar, porém, que o número de instituições diferentes participantes tem aumentado nas reuniões do comitê em questão, assim como nos últimos processos eleitorais realizados para os mandatos de 2007-2013 e 2013-2017).

Assim, a constituição de uma arena de multiparticipantes, tal como os CBHs (WARNER, 2007) é geralmente controversa na medida em que seria uma "situação artificial" na qual as negociações se dão por meio das preferências sobre o quê ou quem deve ser incluído (RÖLING e MAARLEVELD, 1999). Isso conduz à observação sobre a importância de capacitação para a participação, visto que ela neste sentido seria, de alguma forma, seletiva. 
Pois alguns membros são profissionais, treinados e remunerados para tal (Estado, setor produtivo) e outros são voluntários e que podem sofrer assimetrias informacionais. Só que a existência de capacitação ou treinamentos deve levar em consideração a formação de lideranças que (auto)sustentem os CBHs adiante e consolidem a governança hídrica e política.

Por outro lado, interessante notar que os processos participativos (e talvez até os próprios comitês de bacia em geral), se não são adequadamente estruturados e conduzidos, podem retirar poder dos grupos participantes na medida em que alguns deles sejam cooptados por outros melhor estruturados (financeiramente, economicamente e, principalmente, politicamente, etc) (ABERS, 2010).

Tal situação pode gerar, inclusive, a auto exclusão de grupos sociais que acreditam ser esses espaços procedimentos hegemônicos e não de integração (TORTAJADA, 2001). Contudo, os atores sociais também podem atuar em paralelo ao CBHRV ou apenas em algumas situações determinadas, como forma de se manterem autônomos das decisões a serem tomadas.

Todos estes exemplos sinalizam que não há uma temporalidade para que modelos tais como os de comitês comecem a gerar resultados para a gestão hídrica (leia-se aqui maior interação, troca de experiências, formação de plano de trabalho etc), podendo demorar até anos para retirar as instituições de seu arranjo tradicional estabelecido (THEODORO, 2002; THEODORO; MARQUES, 2014). Ao mesmo tempo, o comitê pode ter uma governança insuficiente e mesmo assim gerar resultados para a gestão hídrica, o que, no longo prazo, também sinaliza um amadurecimento da forma de se fazer a gestão dentro do mesmo.

Também, a existência de redes de suporte técnico, humano, enfim, de capacitação e monitoramento da governança envolvida nos processos é, aparentemente, um fator fundamental para que os comitês sejam eficientes, além de poderem garantir sua legitimidade frente aos atores sociais envolvidos nos processos de tomada de decisões (ABERS e KECK, 2013).

Isto nos leva a outro ponto de importância ao se analisar o conteúdo das entrevistas, que são as práticas existentes. Cabe ressaltar aqui mais uma vez que se entende por práticas diferenciadas o rol de atividades que não são usualmente adotadas no cotidiano dos comitês. Não poderiam ser consideradas como inovadoras simplesmente porquê se mostram mais como adaptações sui generis para cada contexto do que a inclusão de procedimentos novos ao 
processo de gestão como um todo. Daí o que se verificou é que o que existem seriam oportunidades de inovação mais do que um processo de planejamento de inovação institucional em si.

Dentre esses momentos pode-se identificar que, tanto a partir dos relatos obtidos nas entrevistas, quanto na observação participante realizada junto ao CBHRV e na AGBPV e também na variada documentação técnica pesquisa, esses acontecimentos seriam:

1) A divisão quadripartite (sociedade civil/grandes usuários/poder público estadual/poder público municipal), fruto do intento de se agregar mais as demandas locais que possam dar força aos municípios e dentro do planejamento do comitê em criar subcomitês;

2) Criação de Câmaras Técnicas (CTs) para aprimorar qualitativamente as discussões geradas, sendo que as 04 atuais tem itens de discussão cada vez mais direcionados ao planejamento de longo prazo do comitê;

3) Redefinição do território da bacia em Unidades Territoriais Estratégicas (UTEs) - a partir das características das Figuras 7.3 e 7.4, com mais coerência demográfica, organizacional e geográfica da bacia (e que surgiu por meio de diálogos entre o CBHRV e AGBPV);

4) Manutenção da presidência do comitê no segmento da sociedade civil, de forma a solidificar a característica de participação democrática;

5) Aumento de parcerias institucionais para as áreas de formação educacional e técnica para a gestão de recursos hídricos, com vistas ao aprimoramento analítico e participativo dos membros e não membros do comitê (Agência Nacional de Águas (ANA); Conselho Regional de Engenharia e Agronomia (CREA); Associação Brasileira de Engenharia Sanitária e Ambiental (ABES), dentre outras).

Porém, cabe destacar, em todos estes posicionamentos, há níveis de participação e controle estatal que possuem mais capacidade de intervenção do que de diálogo institucional, possibilidade já levantada em SWYNGEDOUW (2005). 
Sendo assim, de forma geral identificaram-se os seguintes resultados a partir de toda a triangulação de métodos aplicada, tendo-se aqui como base também as análises realizadas pela análise de conteúdo dos itens mais frequentes relatados nas entrevistas com lideranças do setor:

Quadro 7.1: Participação, Transparência e Práticas no CBHRV

\begin{tabular}{|c|c|c|}
\hline Critérios & \begin{tabular}{|l|} 
Possibilidades \\
\end{tabular} & Restrições \\
\hline Participação & $\begin{array}{l}\text { 1) O avanço da participação no comitê } \\
\text { é quase um consenso e tem tudo para } \\
\text { continuar. } \\
\text { 2) Há mais diversidade de participantes } \\
\text { e com linhas de atuação mais diversa. } \\
\text { 3) Existe demanda reprimida em } \\
\text { relação à capacidade de adesão e } \\
\text { participação de novos membros nos } 04 \\
\text { segmentos, pois a importância do tema } \\
\text { se mostra crescente. }\end{array}$ & $\begin{array}{l}\text { 1) Como o modelo possui um forte laço } \\
\text { estatal, nem sempre o processo se } \\
\text { mostrou tão democrático e participativo } \\
\text { assim. } \\
\text { 2) Muitas vezes o aumento do número e } \\
\text { diversidade de atores não significa um } \\
\text { diferencial qualitativo para a gestão. } \\
\text { Também não implica em participação } \\
\text { mais democrática. Ainda há muito } \\
\text { utilitarismo na dinâmica do comitê, } \\
\text { assim como participação sem } \\
\text { representação efetiva. }\end{array}$ \\
\hline Transparência & $\begin{array}{l}\text { 1) O aumento de estrutura do CBHRV } \\
\text { e da AGBPV possibilitou um } \\
\text { incremento na transparência sobre o } \\
\text { planejamento e execução das ações } \\
\text { institucionais e operacionais. } \\
\text { 2) A gestão com base em planejamento } \\
\text { (com planos de aplicação de recursos) } \\
\text { tem acontecido mais frequentemente. } \\
\text { 3) Os conflitos se tornaram mais } \\
\text { transparentes e possuem agora mais } \\
\text { arenas de discussão do que no formato } \\
\text { original, sendo o aumento do número } \\
\text { de câmaras técnicas e a realização de } \\
\text { reuniões plenárias em outras cidades, } \\
\text { exemplos claros dessas novas } \\
\text { dinâmicas. }\end{array}$ & $\begin{array}{l}\text { 1) Nem todos os participantes do } \\
\text { CBHRV têm conhecimento ou } \\
\text { direcionamento adequado para captar e } \\
\text { entender de forma global o processo de } \\
\text { gestão. A estrutura tem crescido mas a } \\
\text { visão deve ser do processo como um } \\
\text { todo (planejamento, reuniões, decisões } \\
\text { etc). } \\
\text { 2) A prática de planejamento mais } \\
\text { sistemático e de mais longo prazo ainda } \\
\text { está a se consolidar e não é apropriada } \\
\text { por todos os membros e da mesma } \\
\text { forma. } \\
\text { 3) Tão somente a existência de mais } \\
\text { espaços de discussão não assegura que } \\
\text { os processos institucionais gerarão } \\
\text { consensos ou que serão rapidamente } \\
\text { admitidos e/ou implementados. }\end{array}$ \\
\hline Práticas & $\begin{array}{l}\text { 1) A gestão ao nível das microbacias } \\
\text { (subcomitês) tem se revelado bastante } \\
\text { animadora, sendo que a mobilização, } \\
\text { também ao nível local, possibilitou } \\
\text { maior motivação e interesse pelo } \\
\text { CBHRV. } \\
\text { 2) A implantação de projetos } \\
\text { ambientais e de saneamento, } \\
\text { principalmente com foco na gestão } \\
\text { municipal tem sido considerada um } \\
\text { avanço. } \\
\text { 3) A criação de Câmaras Técnicas } \\
\text { (CTs) que, teoricamente, dão suporte à } \\
\text { resolução de conflitos }\end{array}$ & $\begin{array}{l}\text { 1) As inovações estão por vezes } \\
\text { atreladas às amarras da legislação, } \\
\text { principalmente os processos licitatórios. } \\
\text { 2) Os municípios não têm se mostrado } \\
\text { estruturados em termos técnicos, } \\
\text { humanos e materiais para conseguirem } \\
\text { alocar recursos e projetos, ainda, para } \\
\text { suas necessidades. } \\
\text { 3) Os elementos técnicos fornecidos } \\
\text { pelas CTs para auxiliarem as decisões } \\
\text { políticas precisam ser cada vez mais } \\
\text { incorporadas na agenda do comitê. }\end{array}$ \\
\hline
\end{tabular}

Programa de Pós-graduação em Saneamento, Meio Ambiente e Recursos Hídricos da UFMG 


\begin{tabular}{|l|l|l|}
\hline $\begin{array}{l}\text { 4) Há a manutenção de um poder de } \\
\text { decisão de forma quadripartite, com } \\
\text { diferenciação entre poder público } \\
\text { estadual e municipal para aumentar o } \\
\text { poder de voz local. }\end{array}$ & $\begin{array}{l}\text { 4) Existem diferenças muito grandes de } \\
\text { dinâmica e de interesses na forma como } \\
\text { Estado e municípios vêem o comitê e o } \\
\text { sistema de gestão de recursos hídricos, } \\
\text { pois eles têm estruturas operacionais, } \\
\text { recursos humanos e materiais distintos. }\end{array}$ \\
\hline
\end{tabular}

\subsection{CONCLUSÕES}

A partir do que foi proposto na introdução deste trabalho, de tentar identificar as principais restrições e potencialidades existentes para o avanço dos processos de gestão democrática e participativa nas políticas públicas de recursos hídricos pelo estudo de caso do CBHRV, várias conclusões se mostraram possíveis de serem apresentadas. Acredita-se que este trabalho abra, igualmente, perspectivas de aprofundamento teórico e metodológico.

Dentre essas conclusões, primeiramente, cabe aqui reforçar o ponto da ainda necessária consolidação dos processos de participação e controle social que são vinculados ao gerenciamento de recursos hídricos em Minas Gerais e no CBHRV em particular. Devido aos fatos relatados anteriormente, a estrutura de acompanhamento e influência de um CBH frente à estrutura de atuação e controle do Estado ainda é díspar e se encontra em processo de consolidação.

Pois a realização do preceito da "boa governança" em um cenário ainda tão desigual, dificilmente poderá gerar mudanças significativas, mesmo com os diversos exemplos de tentativas de inovação institucional propostas e implantadas pelo CBHRV. A autonomia tão desejada pelos atores sociais, principalmente aqueles oriundos da sociedade civil, é reprimida em nome dos interesses de atuação estatal que, eventualmente, não exerce um reconhecimento das demandas desses em suas definições de agenda ambiental, tal como relatado sobre alguns conflitos de interesses existentes.

O que se percebeu afinal, após as pesquisas de campo e também as análises documentais e afins é que há realmente uma relação paradoxal entre as demandas governamentais que visam ao desenvolvimento de um modelo mais integrado e descentralizado de gestão, mas que, ao mesmo tempo, deixa que o mesmo aconteça apenas na medida em que não emperre seus interesses de agenda política. O que indica que há mesmo lacunas na gestão presente no cenário da gestão presumidamente democrática e participativa no comitê estudado, uma vez

Programa de Pós-graduação em Saneamento, Meio Ambiente e Recursos Hídricos da UFMG 
que a influência estatal se faz presente quando há resistência aos seus interesses (como no caso da crise institucional verificado no ano de 2012).

Objetivamente, há uma autonomia para a gestão democrática e participativa no discurso, mas o que se identificou de fato foi uma relevante presença do Estado nas práticas do comitê pesquisado. Exemplos para isso não se prendem somente ao controle sobre as ações do CBHRV no que tange às determinações de outorgas ou cobranças por uso de recursos hídricos, mas também na estruturação de mobilização social e projetos de intervenção da bacia. Ao mesmo tempo, foi o gerador da estrutura de gestão de recursos hídricos em Minas Gerais, e dentro de uma lógica exógena de desenho institucional, o Estado também se comporta como seu definidor de atuação, mesmo que, pretensamente, se tenha um contexto democrático e participativo de gerenciamento.

Significa, por um lado, uma demonstração do imenso caminho a ser ainda trilhado pelos atores sociais institucionais envolvidos com a gestão hídrica estadual em busca de uma autonomia real de consulta e deliberação de ações e, por outro lado, denota como a boa governança também se encontra inserida em uma realidade de controle institucional muito presente, a confirmar o pressuposto original deste trabalho. O que pode ser identificado a partir desta interação poderia ser traduzido, em nível de um desenvolvimento institucional, em três níveis de articulação que precisariam ser fortalecidos: 1) um sistema organizacional que se conduza por meio de uma gestão eficiente e eficaz; 2) melhore os mecanismos de suporte de decisão por meio da incorporação e interação das diversas experiências e realidades existentes na bacia, principalmente ao nível local; 3) fortalecimento das propostas institucionais para utilização da água em vários níveis (municipal, estadual, federal), através de uma gestão participativa e com planejamento integrado de longo prazo.

Ao se pensar a boa governança para a gestão de recursos hídricos na bacia específica, ficou a pesquisa assim a vislumbrar um contexto paradoxal de autonomia de ações políticas e sociais em alguns momentos da institucionalização do modelo de gerenciamento, mas, por outro, a penumbra do controle estatal a todo o instante denota e impõe limites à mesma estrutura que anteriormente próprio, Estado, contribuir para criar. E essa necessidade de se manter uma agenda com forte base institucional de Estado se revelou ainda constante de acordo com as triangulações de análise realizadas. Superar as restrições já descritas em direção às possibilidades postas pelo conceito de gestão descentralizada, democrática e participativa é 
um desafio que demanda, sem dúvidas, aprofundamentos permanentes de pesquisa e ação social. No caso do CBHRV, por um lado o aumento e manutenção do diálogo com os setores estatais terá de ocorrer, mesmo à custa de vários embates, como por outro lado a recuperação de uma visão de desenho institucional sólida e mais autônoma em relação aos interesses da agenda política governamental é provavelmente muito necessária.

Assim, percebe-se que o tradicional modelo de gestão adormece nas mãos dos expertos e a ampliação participativa é um processo que demanda multi-dimensões e intersetorialidade. Mas o grande atrativo dos CBHs não se relaciona apenas por sua proposta de inserção de atores e sim por: 1) se compor como um modelo alternativo de resolução de conflitos; 2) poder ser considerado como um modelo de gerenciamento adaptativo; 3) ser um caminho para possibilitar maior democratização e empoderamento da governança. Este elenco de possibilidades demostra que o CBHRV pode se consolidar como um espaço de mediação rumo a políticas públicas de boa governança. Se tal irá se confirmar é uma interrogação que somente é superada na medida em que autonomia dos processos de gestão de recursos hídricos no referido comitê for mais assegurada e menos controlada por meio de planejamento e execução adequada de ações. 


\section{OS DESAFIOS INSTITUCIONAIS DE GESTÃO HÍDRICA EM UM MODELO DE PARTICIPAÇÃO QUADRIPARTITE: O CASO DO COMITÊ DA BACIA HIDROGRÁFICA DO RIO DAS VELHAS, MINAS GERAIS, BRASIL ${ }^{75}$}

\subsection{INTRODUÇÃO}

Criado no ano de 1998, o Comitê da Bacia Hidrográfica do Rio das Velhas (CBHRV), localizado no Estado de Minas Gerais, Brasil, possui uma larga experiência na gestão de seus recursos hídricos e também de debate de formatos institucionais possíveis para a tomada de decisões que foram sendo aprimorados no decorrer de seus anos de existência (CAMARGOS, 2005; THEODORO; MARQUES, 2014; THEODORO, 2002). Dentre esses, destaca-se seu formato atual de consulta e deliberação denominado como quadripartite, que engloba a sociedade civil, o setor privado, o setor público estadual e o setor público municipal.

A questão do artigo proposto é tentar apontar os principais obstáculos para que a gestão do CBHRV tanto em termos internos (entre seus membros) como externos (como comitê com outras organizações/instituições) se consolide como pública, participativa, descentralizada e integrada. Ele objetiva elencar as restrições para que os procedimentos de gerenciamento de recursos hídricos, em um modelo quadripartite como o do CBHRV, possam ocorrer de forma harmônica para atuação endógena (organizacional) e exógena (institucional).

Isso porquê, mesmo sendo o referido comitê um dos com maior experiência em gestão participativa de recursos hídricos, ainda possui diversas arestas organizacionais e institucionais que merecem ser melhor estudadas, tanto em sua dinâmica quanto em seu arcabouço institucional. Conseguir estabelecer relações entre os principais conflitos (latentes ou não) entre seus participantes poderá favorecer o entendimento de como melhorar processos de tomada de decisão em ambiente difuso e complexo como o de um comitê de características tão próprias. Dentre essas características pode-se destacar:

1) Sua temporalidade de atuação, desde 1998, logo após a efetivação da Política Nacional de Recursos Hídricos, em 1997 (Lei n 9.433/97), o que acabou por se tornar um referencial na gestão hídrica estadual ao longo dos anos;

75 Artigo enviado, revisado, aprovado e publicado na Revista de Água da América Latina (REGA), Vol. 12, No 1, p. 31-42, jan/jun, 2015, classificação Qualis B3, Engenharias I.

Programa de Pós-graduação em Saneamento, Meio Ambiente e Recursos Hídricos da UFMG 
2) Existência de Região Metropolitana de Belo Horizonte (RMBH), que é composta por 34 municípios $^{76}$, sendo que destes 20 pertencem ao CBHRV. Outro ponto é que a $\mathrm{RMBH}$ possui um diferencial em relação às outras regiões metropolitanas brasileiras que é a existência do chamado Colar Metropolitano, que possui 16 municípios $^{77}$, de onde 4 fazem parte do CBHRV (IPEA, 2013). Isso totaliza no mínimo 77 municípios interligados aos processos de gestão do Rio das Velhas, o que demanda se discutir sobre a gestão urbana (BRITTO; BARRAQUÉ, 2008; BONTEMPO et al., 2012; AROEIRA, 2010);

3) Organização interna com forte presença da sociedade civil que, desde antes da oficialização do comitê, atuava de forma constante na bacia, principalmente através de ações educacionais e de pesquisa. Essas ações eram ligadas à Universidade Federal de Minas Gerais (UFMG), via a Faculdade de Medicina e ao Projeto Manuelzão, um dos principais atores sociais da região e que mantém suas atividades na atualidade;

4) Estrutura para a tomada de decisões com modelo quadripartite, com vista ao aumento da participação, democracia e integração entre os participantes do comitê e que é o objeto de discussão desse artigo.

A necessidade da gestão ser cada vez mais institucionalmente integrada para gerar ações coletivas não é recente (ABERS, 2010; OLSON, 1999) e merece ser aprofundada, principalmente ao nível da análise de governança (GREEN, 2007; GOOCH; HUITEMA, 2004; THEODORO; MATOS, 2015). Da mesma maneira, buscar um maior entendimento das dinâmicas existentes na gestão via bacia hidrográfica, comitês e agências é importante em termos institucionais.

O modelo mais usual de gestão de recursos hídricos em operação no país remete à divisão triparte de segmentos para processos de consultada e deliberação (TURTON et al., 2007; CAMPOS, 2004; CAMPOS e FRACALANZA, 2010):

\footnotetext{
76 Baldim, Belo Horizonte, Betim, Brumadinho, Caeté, Capim Branco, Confins, Contagem, Esmeraldas, Florestal, Ibirité, Igarapé, Itaguara, Itatiaiuçu, Jabuticatubas, Juatuba, Lagoa Santa, Mário Campos, Mateus Leme, Matozinhos, Nova Lima, Nova União, Pedro Leopoldo, Raposos, Ribeirão das Neves, Rio Acima, Rio Manso, Sabará, Santa Luzia, São Joaquim de Bicas, São José da Lapa, Sarzedo, Taquaraçu de Minas e Vespasiano.

Barão de Cocais, Belo Vale, Bom Jesus do Amparo, Bonfim, Fortuna de Minas, Funilândia, Inhaúma, Itabirito, Itaúna, Moeda, Pará de Minas, Prudente de Morais, Santa Bárbara, São Gonçalo do Rio Abaixo, São José da Varginha e Sete Lagoas.
}

Programa de Pós-graduação em Saneamento, Meio Ambiente e Recursos Hídricos da UFMG 
1) Sociedade: formada a partir de organizações civis estabelecidas na área e institucionalmente reconhecidas;

2) Estado: formado com a participação dos diversos poderes públicos constituintes do governo estadual e municipal;

3) Mercado: formado por usuários dos recursos hídricos que fazem captação dos mesmos com possibilidades de alterações diversas de suas disponibilidades, em termos temporal e/ou espacial.

No CBHRV, há uma divisão a mais nessa estrutura clássica. Essa diferenciação se dá no segmento estatal, onde o poder estadual é separado do poder municipal, partindo-se do pressuposto de possuírem dinâmicas e capacidades de intervenção diferentes. A legislação não determina um número ideal de divisões/segmentos, mas sim que haja representação democrática sem setor majoritário existente. Um modelo quadripartite demanda constante interação interna e externa de seus membros, o que é uma dificuldade tanto teórica quanto prática de se realizar (KOOIMAN, 2008; ANA, 2013).

Assim, a discussão contida nesse trabalho se relaciona com a dimensão integradora do CBHRV, que é entendida como a capacidade do objeto pesquisado em organizar e interagir institucionalmente seus segmentos na direção de processos e/ou resultados cada vez mais construídos e consolidados de formas democráticas, participativas e integradas. Mais ainda, a integração foi considerada a partir também de outra possível capacidade/intencionalidade do comitê: de permitir que novos arranjos organizacionais e institucionais possam ser construídos coletivamente e na direção de contextos sociais cada vez mais amplos. Foi feito um recorte de análise justamente nesses dois âmbitos diferentes e interligados: o nível endógeno (organizacional) e o nível exógeno (institucional) do comitê.

O que se fez foi tentar apontar as principais restrições e também possibilidades que tal desenho institucional (CUNHA; THEODORO, 2014) contém para a gestão dos recursos hídricos na área. As premissas foram que, internamente, o CBHRV não possui ainda uma prática de gestão integrada entre seus membros e que, externamente, existem grupos de pressão e poder advindos dos diferentes atores sociais e institucionais existentes na bacia do Rio das Velhas que geram interações diversas entre o comitê, a agência e Estado. 


\subsection{MÉTODOS}

A partir do tipo de objetivo da presente pesquisa, de tentar identificar as principais restrições para que um modelo de gestão participativa funcione, a determinação de um conjunto de métodos e técnicas, mais do que apenas uma em particular, se mostrou necessária. $\mathrm{Na}$ análise de uma dimensão de integração endógena e exógena de um organismo de bacia hidrográfica, além das tradicionais análises documentais que perfilam os limites teóricos de atuação de cada um desses fatores, as análises de campo e, destacadamente, as análises de conteúdo ganham um valor essencial para o aumento da capacidade de explicação do tema selecionado (CÂMARA, 2013). Isso porquê elas podem permitir um alcance maior nas interpretações dos agentes institucionais e sociais envolvidos mais além do que as determinações legais, administrativas e similares que já se encontram estabelecidas (MINAYO, 2012).

Uma vez que se considera aqui o entendimento sobre o processo de gestão dos recursos hídricos via o CBHRV, a busca pelo sentido das falas e ações dos elementos participantes dos processos de decisão na bacia é fator crucial para se tentar identificar lacunas no gerenciamento institucional previsto em lei e do que se espera em si de um comitê de bacia hidrográfica.

Para se poder destacar os principais grupos de pressão, assim como qual o papel de atuação esperado de um comitê como o $\mathrm{CBHRV}$, a metodologia de "triangulação de métodos" (MINAYO, 2005) foi escolhida para ser utilizada, pois permite tanto o descobrimento das experiências de campo, como a base normativa e documental. Foram realizadas 26 entrevistas com lideranças de vários setores direta ou indiretamente relacionados ao tema de pesquisa, de forma a se estabelecer conexões de conteúdo para as análises requeridas. A pesquisa assim se caracteriza como de base qualitativa (FLICK, 2009) e com orientação de conjugação de análises diferenciadas por técnicas de espaços e tempos diferentes.

Utiliza-se aqui como arcabouço de análise:

1) Análise de Campo: tem como princípio a técnica da "observação participante" (HAGUETTE, 2000), consolidada como instrumento para se captar o modus operandi do(s) grupo(s) escolhido para investigação. Detém como característica a possibilidade que permite ao pesquisador obter dados e informações através da lente do cotidiano ou de eventos particulares significantes ao trabalho proposto. Nessa técnica, a observação 
ocorre na participação junto ao grupo observado, de forma direta ou indireta, possuindo dificuldades e possibilidades próprias ao seu exercício, como a necessidade de constante vigilância sobre a objetividade de tudo o que é coletado e interpretado.

2) Análise Documental: tem como princípio a organização dos dados e informações existentes e sua consequente categorização para posterior estudo. Caracteriza-se por permitir ao pesquisador a separação, catalogação e comparação de informações em fontes diferentes no tempo, espaço, conteúdo, redação e público-alvo. O rol selecionado de documentos inclui as determinações legais e administrativas sobre o comitê referido, como consultas, propostas, deliberações e decisões, como também a produção teórica vinculada ao tema, tanto em âmbito governamental como acadêmico. O foco é o rol de informações relacionadas ao tema pesquisado.

3) Análise de Conteúdo: tem como princípio estabelecer como um conjunto de técnicas de pesquisa que visa à busca de sentido(s) em um dado documento pela utilização de procedimentos sistemáticos e objetivos (BARDIN, 1994; CAMPOS, 2004). Possui como método a possibilidade de inferências sobre a produção/recepção/distribuição das mensagens avaliadas. $\mathrm{O}$ foco se faz sobre o processo de comunicação existente em um determinado evento, atividade, prática e não somente nos dados em si.

Especificamente sobre o aspecto da dimensão integradora presente no CBHRV dentro da triangulação proposta a análise de conteúdo tem um espaço maior, uma vez que foi por ela, principalmente, que as questões subjacentes à gestão hídrica se tornaram evidentes a partir da série de entrevistas realizadas. De acordo com Bardin (1994), são necessárias determinadas etapas para que as análises qualitativas de conteúdo sigam um caminho mais orientado para captação de dados e de forma a serem também fundamentais como organização da técnica proposta.

Primeiramente, porém, se faz necessário explicar como se deu o processo de construção dessas etapas, que foram realizadas no período entre 2012 e 2015 de maneira a permitir resgatar a construção documental relativa ao tema proposto como também acompanhar as modificações legais, administrativas e institucionais que ocorreram no período. Cabe ressaltar também que o processo de observação participante sobre a gestão que deu suporte às análises ocorreu desde o ano 2000, quando o primeiro autor desse trabalho passou a atuar direta e 
indiretamente em atividades do comitê (reuniões plenárias, extraordinárias, câmaras técnicas, eventos).

Fosse como representante do setor de educação superior (entre 2004 a 2011) ou como representante da Associação Brasileira de Engenharia Sanitária e Ambiental (desde 2012), a opção pela observação participante (onde a "observação" se dá pela "participação" daquele que está pesquisando um dado fenômeno - no caso, a gestão de recursos hídricos via comitê) se mostrou a mais adequada para tentar compreender os discursos, os conteúdos e as práticas existentes no CBHRV.

Sobre os procedimentos em relação aos documentos analisados, destaca-se:

1) Pré-análise: estruturação inicial do material a ser trabalhado: $O$ intuito foi tentar identificar as principais restrições e potencialidades envolvidas na gestão de recursos hídricos via CBHRV, e com foco na dimensão de integração das atividades deste. Assim, o recorte temporal foi feito levando-se em consideração às principais legislações e documentos sobre recursos hídricos formulados a partir da década de 1980, quando aconteceu a institucionalização da temática de forma mais abrangente. Esse movimento se deu principalmente a partir da Constituição Federal de 1988, que ressaltou a questão da participação e democratização social em relação ao meio ambiente, que passou a ser considerado como direito fundamental para o exercício pleno da cidadania. Mais especificamente em relação ao $\mathrm{CBHRV}$, foram consideradas as consultas, propostas, deliberações e decisões diretas ou indiretamente ligadas ao mesmo.

2) Exploração do material: escolhas das categorias de análise: As categorias de análise consideradas foram aquelas que indicaram possibilidades de explicar o perfil do comitê em termos de suas interações internas e externas. Sendo assim, elas cobrem a tríade necessária à avaliação socioambiental: meio físico (uso/ocupação do solo); meio biótico (quantidade de água; qualidade de água; bioindicadores); meio antrópico (dimensões de cunho: institucional, integradora (tema deste artigo), legal e econômica-financeira).

Consequentemente, nessa etapa foi construída uma estrutura de roteiro de entrevista formada por essas oito temáticas que foram discutidas a partir de 18 perguntas, aplicadas a 26 lideranças que compuseram o painel de entrevistados selecionados. Tal seleção se deu pela liderança e reconhecimento dos entrevistados sobre a temática do CBHRV, tanto no 
setor administrativo, técnico, social e acadêmico. $O$ formato de entrevista permitiu a exploração dos temas a partir da interpretação dos próprios escolhidos que, de forma geral, responderam todas as perguntas e permitiram a gravação de suas respostas, salvo um único caso, que duraram em torno de 50-60 minutos para sua aplicação.

3) Tratamento dos resultados: busca pela significação e validação dos dados: Após a estrutura do material e da definição das categorias, o tratamento dos dados aconteceu pela identificação dos principais temas que foram enunciados nas entrevistas e confrontados com as experiências de campo e análise de documentos. Essa triangulação permitiu o avanço do trabalho no sentido de esclarecer possíveis potencialidades e restrições aos processos de integração do comitê na medida em que não somente as informações, mas também os sentidos inseridos nelas por seus autores. Essas significações se deram principalmente pela análise de conteúdo, que não se atém simplesmente ao discurso inerente a cada entrevista/entrevistado. Ao contrário, ela permitiu tratar os dados na direção de explicações e não somente descrições dos eventos. No caso da dimensão integradora isso foi fundamental por indicar caminhos para um maior conhecimento da gestão institucional de recursos hídricos da qual o CBHRV faz parte.

Cada uma das etapas descritas foi aplicada na pesquisa e todas foram importantes para a identificação das diversas questões latentes e explícitas na gestão endógena e exógena do CBHRV. Essas mesmas etapas foram construídas a partir da perspectiva de manutenção da confiabilidade e da validade das mesmas enquanto instrumentos metodológicos de pesquisa (GOLAFSHANI, 2003), de forma a impedir análises enviesadas sobre a gestão.

Para a seleção e execução das entrevistas e da análise documental, por exemplo, os preceitos de representatividade da amostra, pertinência dos temas e dos documentos e da exaustividade dos temas foram considerados para aprofundar a pesquisa (BARDIN, 1994). Em relação à observação participante, os cuidados tomados e exercidos pelo primeiro autor deste artigo foram no sentido de um afastamento gradativo de suas funções como membro do CBHRV, de forma a possibilitar uma leitura mais objetiva e sistemática de suas decisões e ações.

\subsection{RESULTADOS E DISCUSSÃO}

De acordo com a Lei Federal $n^{\circ}$ 9.433/97 - que institui a Política Nacional de Recursos Hídricos (PNRH) e cria o Sistema Nacional de Gerenciamento de Recursos Hídricos 
(SINGREH), formado pelos Conselhos, Ministério do Meio Ambiente (MMA)/Secretaria de Recurso Hídricos e Ambiente Urbano (SRHU), Agência Nacional de Águas (ANA), Órgãos Estaduais, Comitês de Bacia Hidrográfica $(\mathrm{CBH})$ e Agências de Água) - a representação nos comitês deve ter indivíduos (Art. 39): da União; dos Estados e do Distrito Federal cujos territórios se situem, ainda que parcialmente, em suas respectivas áreas de atuação; dos Municípios situados, no todo ou em parte, em sua área de atuação; dos usuários das águas de sua área de atuação; das entidades civis de recursos hídricos com atuação comprovada na bacia.

Mais ainda, no parágrafo primeiro deste mesmo artigo, salienta-se que o número e critérios de composição serão estabelecidos nos próprios comitês, desde que a representação estatal não seja maior do que a metade do número total de participantes. Isto significa que, teoricamente, o modelo de representação proposto legalmente versa sobre a possibilidade da dimensão integradora no comitê seja estabelecida por um diálogo constante entre suas partes formadoras (sociedade civil, usuários e Estado). Nesse sentido, seria um pressuposto para práticas de boa governança, compreendida aqui, dentre as várias perspectivas possíveis (GREEN, 2007; THEODORO; MATOS, 2015), como a articulação institucional com ampla participação, capacidade de inclusão e de resposta às demandas dos participantes dos processos de decisão, que devem ser transparentes e acessíveis.

Porém, consequente à referida lei, foi editada a Resolução no $5 / 2000$, pelo Conselho Nacional de Recursos Hídricos (CNRH), que definiu valores máximo, mínimo e fixo para a composição de CBHs no país, tais como: Estado com $40 \%$ de representação máxima; sociedade civil com $20 \%$ de representação mínima; usuários com $40 \%$ de representação fixa, respectivamente. $\mathrm{O}$ fato que demonstra a dificuldade em se integrar os segmentos participantes, é que alguns CBHs já tinham legislação anterior por terem sido criados há mais tempo do que a Resolução $n^{\circ}$ 5/2000 e, consequentemente, se estruturaram de forma diferente da determinação legal (BRASIL, 1997). Isto faz com que existam diferentes desenhos institucionais para compor comitês no país, com os segmentos a terem maior ou menor espaço representativo, tal como se vê na Tabela 8.1.

O CBHRV tem uma composição onde o poder estatal é representado por $50 \%$ dos participantes, o nível máximo permitido pela Lei Federal $n^{\circ} 9.433 / 97$, e superior ao limite indicado pela Resolução no 5/2000 do CNRH. Este comitê possui a participação igualitária de 
seus membros ( $25 \%$ do percentual total), que são 56 no total, sendo 28 titulares e 28 suplentes.

Mas esse recorte representacional do CBHRV não deve ser entendido apenas como uma configuração legal e tal desenho institucional encontra respaldo mais em suas origens históricas do que no arcabouço jurídico (NOGUEIRA, 2004). Desde sua criação por meio do Decreto Estadual 39.692, em 29 de junho de 1998, a questão da representação paritária quadripartite foi colocada. De acordo com as análises metodológicas de conteúdo realizadas junto às entrevistas com lideranças, o diferencial deste comitê em separar a representação estatal em Poder Público Estadual e Poder Público Municipal foi resultado da preocupação em evitar que as representações locais ao longo da bacia, leiam-se prefeituras, estivessem enfraquecidas ou com pouca capacidade de intervenção.

Assim o modelo de gestão quadripartite foi pensado como possibilidade de atuação mais abrangente tanto da sociedade civil como dos outros segmentos, uma vez que teriam de discutir e tomar decisões de forma ainda mais conjunta do que o modelo tripartite. A ideia de uma divisão de segmentos vai à direção de se evitar a formação de maioria simples para a tomada de decisões por um segmento qualquer (NEDER, 2015). Dessa forma a condicionante de decisão conjunta estaria colocada de forma mais distribuída, indo além da noção tradicional de gestão como determinante do aparato estatal (SWYNGEDOUW, 2005).

Tabela 8.1: Análise comparativa entre alguns $\mathrm{CBHs}$

\begin{tabular}{l|c|c|c}
\hline Comitê & Poderes Públicos & Usuários & Organizações Civis \\
\hline Alto Tietê (SP) & 66,7 & 14,8 & 18,5 \\
\hline Velhas (MG) & 50 & 25 & 25 \\
\hline Meia Ponte (GO) & 40 & 40 & 20 \\
\hline Curu (CE) & 40 & 30 & 30 \\
\hline CEIVAP (MG, RJ e SP) & 38 & 40 & 22 \\
\hline Recôncavo Norte (BA) & 33,3 & 33,3 & 33,3 \\
\hline Lagos São João (RJ) & 33 & 33 & 33 \\
\hline Alto Iguaçu e Alto Ribeira (PR) & 31,6 & 36,8 & 31,6 \\
\hline Sinos (RS) & 20 & 40 & 40
\end{tabular}

Fonte: ANA (2011), IGAM (2011).

Um possível diferencial, ao menos ao nível conceitual, da representação por modelo quadripartite seria justamente permitir maior ambiente de negociação de propostas e deliberações institucionais entre os segmentos, mas mantendo-se o caráter de integração 
governamental via o próprio comitê de bacia (CAMPOS, 2004; CAMPOS e FRACALANZA, 2010).

Nesse sentido, ressalta-se que o modelo de gestão via comitê apresenta, teoricamente, a proposta de interação organizacional para a ação, diferentemente de outros modelos de gestão por conselhos e afins. Os comitês não são apenas consultivos, como também propositivos e, principalmente, deliberativos (tomam decisões). Isto significa que possuem poder de Estado na medida em que definem a utilização ou não de um bem público, com poder legal para tal e para se fazer executar (POMPEU, 2010; BRASIL, 1997). Ao mesmo tempo, porém, uma verificação sobre a competência legal dos CBHs (Art. 38 da Lei Federal 9.433/97) demonstra que esse poder de "deliberar" aparece de forma limitada e passível de ser modificada em instâncias superiores (Conselho Estadual de Recursos Hídricos (CERH); Conselho Nacional de Recursos Hídricos (CNRH) via recursos na esfera devida pelo proponente).

Esta relação é institucionalmente orientada para criar uma vinculação de gestão entre os entes federados de forma ascendentes. Por exemplo, esta estrutura assegura espaços organizacionais de negociação entre os interesses locais, regionais e nacionais dos segmentos, principalmente quando se considera a perspectiva de uma gestão por bacia(s) hidrográfica(s), interdependentes. Verifica-se que este sistema de deliberações escalares na verdade é uma prerrogativa de garantia de direitos e deveres para o fim de uma gestão participativa e integrada de recursos hídricos.

Ao mesmo tempo, considerar que o modelo de comitê é uma nova forma de participação apenas porquê existe participação direta pode mascarar uma visão maior de como funciona o sistema de tomada de decisão sobre recursos hídricos e suas interações em termos de governança. Em termos práticos, por exemplo, uma decisão tomada ao nível do comitê de bacia não quer dizer que será necessariamente seguida e respeitada ou não alterado em instâncias superiores. Ela é apenas uma das etapas de discussão e deliberação existentes dentro do Sistema Nacional de Gerenciamento de Recursos Hídricos (ANA, 2011).

Da mesma forma ocorre com as agências de água, em termos de limitações de atuação. Uma vez que não têm papel de regulação, que é dado à ANA, elas podem agir apenas como secretarias executivas de seus respectivos comitês, inseridas em suas funções técnicasadministrativas. São por vezes consultivas, mas não deliberativas dentro da estrutura atual (e nem poderiam, pois essa ação é definida aos comitês). Mas uma preocupação recorrente 
identificada nas entrevistas foi justamente tentar compreender melhor qual o papel das agências dentro do sistema de gestão de bacia estabelecido, pois, para algumas lideranças, quem definiria a pauta de discussão sobre os recursos hídricos em Minas Gerais, por exemplo, seria a ANA mais do que os próprios comitês.

Alerta-se, porém, que há também reconhecimento, por parte dos entrevistados, de uma gradativa e maior atuação da agência de água responsável, a "Associação Executiva de Apoio à Gestão de Bacias Hidrográficas Peixe Vivo" (AGBPV) e também da ANA no sentido de auxiliar o CBHRV a tomar suas decisões de maneira mais integrada em termos organizacionais/institucionais.

Um exemplo seriam os projetos hidroambientais e de formação técnica e administrativa para planos municipais de saneamento. Nota-se que o nível de percepção e limites sobre a atuação da agência e do comitê também é um processo ainda em formação, pois, tal como registrado em entrevista com uma liderança, deveria ficar claro a todos os membros que “(...)o CBHRVé o cérebro e a AGBPV são os braços.".

Um problema é que essa capacidade pretensa de atuação integrada e participativa demanda nível de organização interna e externa que pode não ocorrer, visto que são processos técnicos e políticos de nível também contextual. De natureza igual, o papel previsto de ação do comitê de bacia de ser capaz de fazer representar adequadamente diversos atores sociais e institucionais em uma arena democrática e participativa com vistas ao aprimoramento da gestão hídrica pode nem sempre ou nunca ser exercido caso sua articulação interna e externa não se consolide.

\subsubsection{Estruturação endógena do CBHRV}

O CBHRV tem uma estrutura quadripartite pouco usual, mas que segue de forma bem próxima àquela indicada nos órgãos técnicos. Possui Plenária para as reuniões ordinárias de seus 56 membros e não membros (a se destacar que todos os encontros são de ordem e fé pública, e podem ser acompanhados por qualquer indivíduo pertencente ou não à bacia hidrográfica do Rio das Velhas); possui Presidência e Diretoria Colegiada, que agem em conjunto para as interações políticas internas e externas; Câmaras Técnicas (Projetos e Controle; Institucional-Legal; Outorga e Cobrança; Comunicação) e Secretaria Executiva (AGBPV). Ao nível comparativo, a estrutura do CBHRV é muito similar também ao tipo de

Programa de Pós-graduação em Saneamento, Meio Ambiente e Recursos Hídricos da UFMG 
desenho institucional encontrado no comitê da bacia hidrográfica ao qual é tributário, que é o do Rio São Francisco (CBHSF).

Entretanto, esse possível "mimetismo institucional” não é uma regra nem encontra orientação definitiva em nenhuma legislação pertinente, mas sim orientações de cunho geral para que sejam realizados os trâmites administrativos requeridos em lei da melhor forma possível.

De acordo com as análises de conteúdo, ficou identificado também que o nível de conhecimento técnico sobre os assuntos tratados no comitê são por vezes assimétricos e, consequentemente favorecem a influência de alguns grupos citado vem dos grupos econômicos que permeiam o comitê, com destaque aos setores de mineração e agricultura, que utilizam recursos hídricos em suas operações.

Alia-se a isso o fato de que há muito planejamento nos processos de gestão de recursos hídricos que, para ser implantados, necessitam de um conhecimento técnico mínimo que não se encontra em toda a bacia ou nos quadros de pessoal dos subcomitês e prefeituras.

De acordo com relatos obtidos nas entrevistas, há uma percepção de que há um peso político e administrativo maior da representação da RMBH do que dos outros territórios na bacia, seja pela capacidade de articulação dos mesmos ou pelos atores institucionais e sociais envolvidos. Isso resulta em uma gestão limitada aos mesmos grupos institucionais e de interesses, a manter as contradições de uma proposta que seja além das tradicionais (SWYNGEDOUW, 2005).

Apesar da participação ser considerada alta tanto por membros quanto por especialistas, o saber técnico e a interação política pessoal e institucional seriam fatores importantes para a realização da gestão. Isso faz também com que o nível de execução de tarefas pelo comitê seja considerado apenas regular, pois depende de outros organismos de bacia para acontecer.

Outro fato que poderia justificar um pouco mais a relação causal entre representação precária e execução de decisões pode ser identificado pela dificuldade das instituições públicas em reconhecerem as decisões tomadas via modelos de comitês e de representação em geral (ABERS, 2010), fazendo com que articulações governamentais não aconteçam. Certamente que o CBHRV tem independência, podendo deliberar possíveis mudanças ao nível interno de 
sua estrutura, mas como responde a um sistema de gestão de recursos hídricos maior, seu nível de influência ainda está em consolidação.

\subsubsection{Estruturação exógena do CBHRV}

Quando se observa a gestão de um dado comitê de bacia hidrográfica inserido em um sistema de gestão hídrica maior e sob uma perspectiva de governança, a questão de seu relacionamento interinstitucional se torna fundamental para tentar entender seus níveis de atuação. Na verdade, um dado comitê é apenas um dos vários elementos componentes do SINGREH e, mesmo dada sua importância como mecanismo de participação social multidimensional, ele é interinstitucional e, como tal, deve compreender seus limites de atuação dentro sistema.

Mais ainda, ao se analisar a composição do referido sistema, a documentação legal e institucional relativa e às entrevistas realizadas, o papel dos $\mathrm{CBHs}$ poderia ser identificado tanto como basilar como, ao mesmo tempo, dependente de uma série de outras instituições para poder exercer suas funções da forma prevista.

Uma prova dessa situação pode ser demonstrada quando se verifica que o poder de decisão dado ao órgão é a Agência Nacional de Águas (ANA) que irá exercer a ação regulatória e de integração entre os organismos de bacia (comitês, agências específicas por bacia, conselhos etc). Ela, agência, enquanto escritório técnico deve ser capaz de assessorar os comitês a desempenhar suas funções a todo instante, o que pode ter gerada a desconfiança sobre os limites de atuação da instituição por parte de alguns membros do CBHRV.

Essa situação de possível concentração de poder decisório na instância federal via agência reguladora já havia sido indicada anteriormente (THEODORO, 2002) e também foi relatada pelos entrevistados e identificada de forma regular em documentos relativos às reuniões ordinárias e extraordinárias do CBHRV (CBHRV, 2012) e eventos similares de outros órgãos e entidades ligadas ao tema e que foram pesquisados.

Porém, o que se verifica em uma análise mais ampla é que a ANA está exercendo seu poder de regulação, mas não de deliberação sobre as decisões dos comitês do país e do CBHRV, em particular, o que nem sempre está claro aos seus membros (ABERS, 2010).

Programa de Pós-graduação em Saneamento, Meio Ambiente e Recursos Hídricos da UFMG 
Mesmo que um entrevistado tenha afirmado que “(...) a ANA é quem define a pauta sobre recursos hídricos em Minas Gerais", existe uma capacidade de influência do órgão, mas não de interferência nas decisões, pois tal ação feriria o princípio do próprio modelo de gestão de fortalecer as decisões ao nível da bacia hidrográfica. De forma geral, o que se identifica é uma enorme constituição de órgãos ligados aos recursos hídricos, uma vez que existem departamentos, secretarias, superintendências e afins em cada instituição estadual ou nacional.

Ao se tentar verificar os papéis de atuação de várias delas, fica claro que são recortes muito semelhantes e até sobrepostos (WARNER, 2007), o que não ajuda a se definir com tanta objetividade, qual o órgão responsável por qual ação de planejamento, monitoramento ou avaliação, por exemplo. De acordo com as análises de conteúdo, o país e o Estado de Minas Gerais ainda favorecem um tipo de desenho institucional de difícil interpretação para o público em geral, salvo os especialistas, sendo que tal dificuldade existe também dentro dos próprios CBHs (ABERS, 2010, NOGUEIRA, 2004).

As instituições foram criadas em ambientes históricos, sociais e políticos diferentes, com tarefas de perspectivas também distintas. Quando se adiciona a esta situação o fato de que o arcabouço institucional e jurídico é diversificado e complexo vê-se que ainda é difícil a interação entre os órgãos componentes. Percebe-se que a política prescreve um modelo de gestão descentralizado, democratizado e participativo, mas, na realidade, a atuação é considerada como centralizada e cartorial, de acordo com as análises realizadas a partir das entrevistas. Centralizada na medida em que nem todos os membros se encontram nas mesmas condições técnicas e de poder organizacional para influenciar os processos institucionais. E cartorial porque os procedimentos de tomada de decisões estão fortemente baseados nos preceitos legais e administrativos, mais do que na gestão em si.

Especificamente sobre a temática institucional, ficou evidenciada a preocupação das lideranças sobre a real capacidade de atuação do modelo de gestão via comitê ser integrado atualmente, pois seria uma arena de discussões mais democrática que a usual, mas ainda de pouca influência no sistema como um todo.

Um fato que identifica isto é que cada instituição componente do sistema age por si mesma e não costuma agir conjuntamente a outras no planejamento de suas ações. O poder público, destacadamente, o estadual e o federal, ignoram as decisões do comitê e não dialogam com o mesmo de forma permanente. Casos de entidades da sociedade civil, inclusive ao nível 
acadêmico, não são consultadas sobre eventuais ações na bacia hidrográfica, foram identificados em vários momentos da pesquisa - fosse como representação do segmento da sociedade civil ou como consulta para tomada de decisões.

A composição dos secretariados, municipais e estadual, diretamente relacionados com a gestão ambiental e hídrica é tida como exemplo da falta de interação interinstitucional, na medida em que não são normalmente alinhados, de acordo com os entrevistados, com as propostas de gestão em discussão há vários anos no CBHRV.

Mais ainda, seus "representantes" não são eventualmente pessoas/lideranças do setor ambiental/hídrico e assim, pouco diálogo institucional é realizado Isso reflete uma incapacidade da realização de uma política de boa governança na medida em que a participação ao máximo possível de todos os atores sociais é um pressuposto da mesma (TORTAJADA, 2001; GREEN, 2007; THEODORO; MATOS, 2015).

Assim, pode-se identificar que o CBHRV também não possui uma prática de gestão integrada ao nível endógeno, analisada comparativamente no Quadro 8.1, pois:

1) A prática da gestão quadripartite é muito nova e bem pouco usual dentro do sistema de gestão estadual e nacional, o que acarreta diferentes leituras pelos membros do poder público em outras instâncias;

2) Mesmo sendo um dos pioneiros e dos mais influentes comitês de bacia hidrográfica, o CBHRV está inserido em discussões e determinações que envolvem outros comitês de constituições muito distintas - lembrando que só no Estado de Minas Gerais há 36 Unidades de Planejamento e Gestão de Recursos Hídricos (UPGRHs);

3) Os recursos necessários para que haja uma estruturação considerada como adequada pelos membros e especialistas na gestão dos recursos hídricos em termos institucionais e que incluiria melhorias significativas na troca de informações, integração de dados e informações está muito aquém do necessário;

4) Grupos econômicos têm demonstrado possuir muito mais poder de influência e coalização de interesses entre/inter instituições do que os CBHs e o CBHRV, em particular; 
5) Tal como no âmbito endógeno, os instrumentos de gestão são considerados em diferentes perspectivas, de acordo com os interesses de cada segmento;

6) As decisões que são tomadas ao nível do comitê não são necessariamente aceitas, respeitadas ou implantadas como previstas pelas instituições públicas de direito, fato já evidenciado em Abers (2010); Theodoro e Marques (2014); Nogueira (2004).

Quadro 8.1: Restrições e possibilidades à integração endógena e exógena do CBHRV

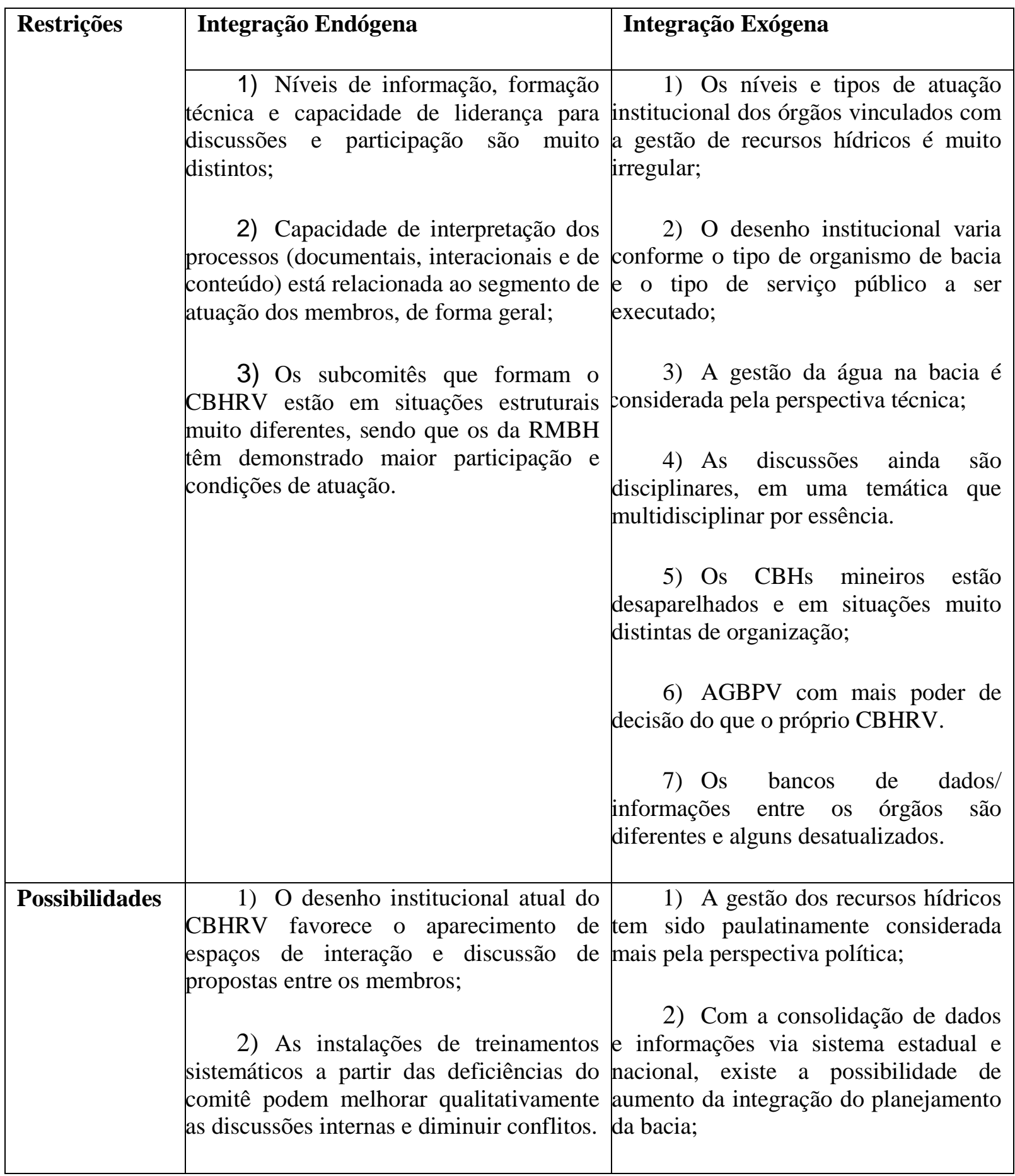

Programa de Pós-graduação em Saneamento, Meio Ambiente e Recursos Hídricos da UFMG 


\subsection{CONCLUSÕES}

Nesse artigo foi possível abordar alguns pontos pertinentes à gestão de recursos hídricos em um comitê de bacia que adota um modelo quadripartite de tomada de decisões, que é o CBHRV. Para sua realização, vale notar que a aplicação de metodologia de triangulação de métodos (trabalho de campo; documentos; entrevistas com lideranças) se mostrou apropriada para a identificação de algumas restrições e potencialidades a serem consideradas em políticas públicas futuras.

Verificou-se que dentre as principais restrições do comitê estudado para um bom desempenho funcional, em caráter endógeno, as assimetrias existentes em termos de acesso e interpretação informacional, técnico e estrutural estão muito presentes.

Isso se reflete em dificuldades para a construção de uma agenda mais propositiva ao comitê. Por outro lado, o modelo quadripartite favorece que haja maior interação entre os atores institucionais com possibilidades de decisões mais participativas e democráticas ao longo prazo. Já externamente, o CBHRV enfrenta como desafio a questão de que a gestão hídrica tem sido considerada como um viés técnico muito mais recorrente do que político, que é a essência da ideia de comitê.

Esse fato corrobora a importância de que modelos de desenho institucional de representação na gestão, não só o quadripartite, sejam cada mais implementados para se favorecer o acesso à tomada de decisões por todos os segmentos interessados. No ambiente do comitê estudado, os discursos e argumentações técnicas ganham espaços que, originalmente, foram pensados para serem ocupados pelas demandas sociais em processos de interação e, assim, análises como as aqui efetuadas devem se tornar constante para favorecer maior aprofundamento do tema.

Adiciona-se a isto que os governos não têm demonstrado uma aproximação com a sociedade civil e, de acordo com as análises de campo e de conteúdo, a mesma não participa de forma consultiva/deliberativa das definições governamentais relativas à agenda ambiental e hídrica, o que enfraqueceria a consolidação de um processo de governança integrado.

Mais ainda, se identificou que a estrutura não somente informacional, mas também física e de recursos humanos envolvidos na gestão é bastante variável. O se percebe a partir daí é que 
os aprimoramentos institucionais necessários para o modelo quadripartite avançar, no CBHRV, especificamente, suas discussões e aplicações, ainda estão em andamento, na direção de efetivamente praticarem uma boa governança. Destaca-se que esse processo para se efetivar políticas públicas sob uma ótica da governança é ato contínuo em termos institucionais e sociais. Nesse sentido, coloca-se a perspectiva de que análises constantes das suas restrições e potencialidades para futuros aprimoramentos se mostra necessária para a superação dos desafios postos ao modelo quadripartite. 


\section{DESCENTRALIZAÇÃO INSTITUCIONAL E GESTÃO DE RECURSOS HÍDRICOS SOB O ENFOQUE LEGAL: O CASO DO COMITÉ DA BACIA HIDROGRÁFICA DO RIO DAS VELHAS, MG, BRASIL $^{78}$}

\subsection{INTRODUÇÃO}

A gestão ambiental se situação, em termos jurídicos, dentro dos denominados "Direitos de Terceira Geração" (JÚNIOR, 2006), ou seja, ela se relaciona com os direitos coletivos, que envolvem desde a qualidade de vida até questões sobre a autodeterminação dos povos. Esses direitos significam que a coletividade, mais do que o indivíduo considerado de forma isolada, deve ser protegida. $\mathrm{O}$ meio ambiente, consequentemente, faz parte, constitucionalmente, dos direitos e garantias fundamentais que devem ser oferecidas pelo Estado de forma a garantir a melhor condição possível ao andamento das funções públicas e sociais e também pessoais.

Por outro lado, mesmo a estar baseada em medidas legais para sua operacionalização, a gestão de recursos hídricos possui características muito além do que apenas as determinações normativas são capazes de estabelecer. Deve, portanto, procurar interagir com o máximo de possibilidades de campos de conhecimento e de técnicas possível de forma a criar um entendimento maior de sua capacidade de intervenção sobre a realidade.

Outrossim, a vinculação entre a gestão hídrica e as políticas públicas é um movimento que deve ser mais estudado e praticado, principalmente na direção de uma perspectiva de incorporação da gestão pública. Este conceito é aqui considerado como a capacidade da criação, manutenção e/ou consolidação de redes de trabalho para a implantação de decisões institucionais coletivas. O sentido passa a ser de se fazer integrar atores sociais formais e informais que possam realizar acordos e arranjos institucionais mais participativos realmente (FREY, 2000; CARVALHO, 1998) e que sejam também democráticos e eficientes (que gerem melhor aproveitamento de recursos humanos, materiais e naturais).

Quer dizer, há uma necessidade de se aprimorar as funções públicas para além do exercício tradicional de poder de atuação do Estado (SWYNGEDOUW, 2005) vista a demanda

\footnotetext{
78 Artigo enviado, revisado e aprovado para publicação na Revista Brasileira de Engenharia de Biossistemas (BIOENG), classificação Qualis B4, Interdisciplinar.
}

Programa de Pós-graduação em Saneamento, Meio Ambiente e Recursos Hídricos da UFMG 
crescente por uma aplicação de abordagens interdisciplinares como possibilidade de aumento da capacidade de explicação na área (BRITO et al., 2012).

Até porquê, a eficiência buscada em processos de gestão institucional participativa pode ser bem diferente daquela busca pela origem do tradicional do termo governança (SWYNGEDOUW, 2005), onde havia uma grande tendência de visão economicista e estatal (BANCO MUNDIAL, 1992).

O objetivo da pesquisa foi de se tentar identificar as principais possibilidades e também as restrições existentes no modelo de gestão que se pretende descentralizado e democrático. $\mathrm{Na}$ mesma medida, se busca se identificar possíveis efeitos esperados advindos das atuações de um comitê dentro do contexto de gestão institucional-legal existente. Como objeto de estudo se tem a bacia hidrográfica do Rio das Velhas e de seu comitê direto, a ser considerado como CBHRV de agora em diante.

Nessa direção se tem como questão de pesquisa o questionamento sobre quais os fatores que demonstram as relações institucionais e jurídicas e os processos de gestão ao nível da bacia hidrográfica do Rio das Velhas. Também se via depreender quais seriam as possíveis ações de atuação do referido comitê que se mostram capazes de aproximarem ou distanciarem os dos escopos de atuação jurídica/gerencial previstos.

Consequentemente, a hipótese de pesquisa que se revela é a de se tentar assinalar há distâncias conceituais e operacionais existentes entre as determinações legais da gestão (conjunto de leis, deliberações normativas, decretos etc) e as práticas e resultados alcançados ao nível do CBHRV. Isso se faz necessário para viabilizar o entendimento das dinâmicas dos processos de tomada de decisões na gestão hídrica nacional e, primordialmente, estaduais, visto que a apropriação histórica desse sistema ainda é recente, como se pode verificar na Figura 9.1 posterior: 


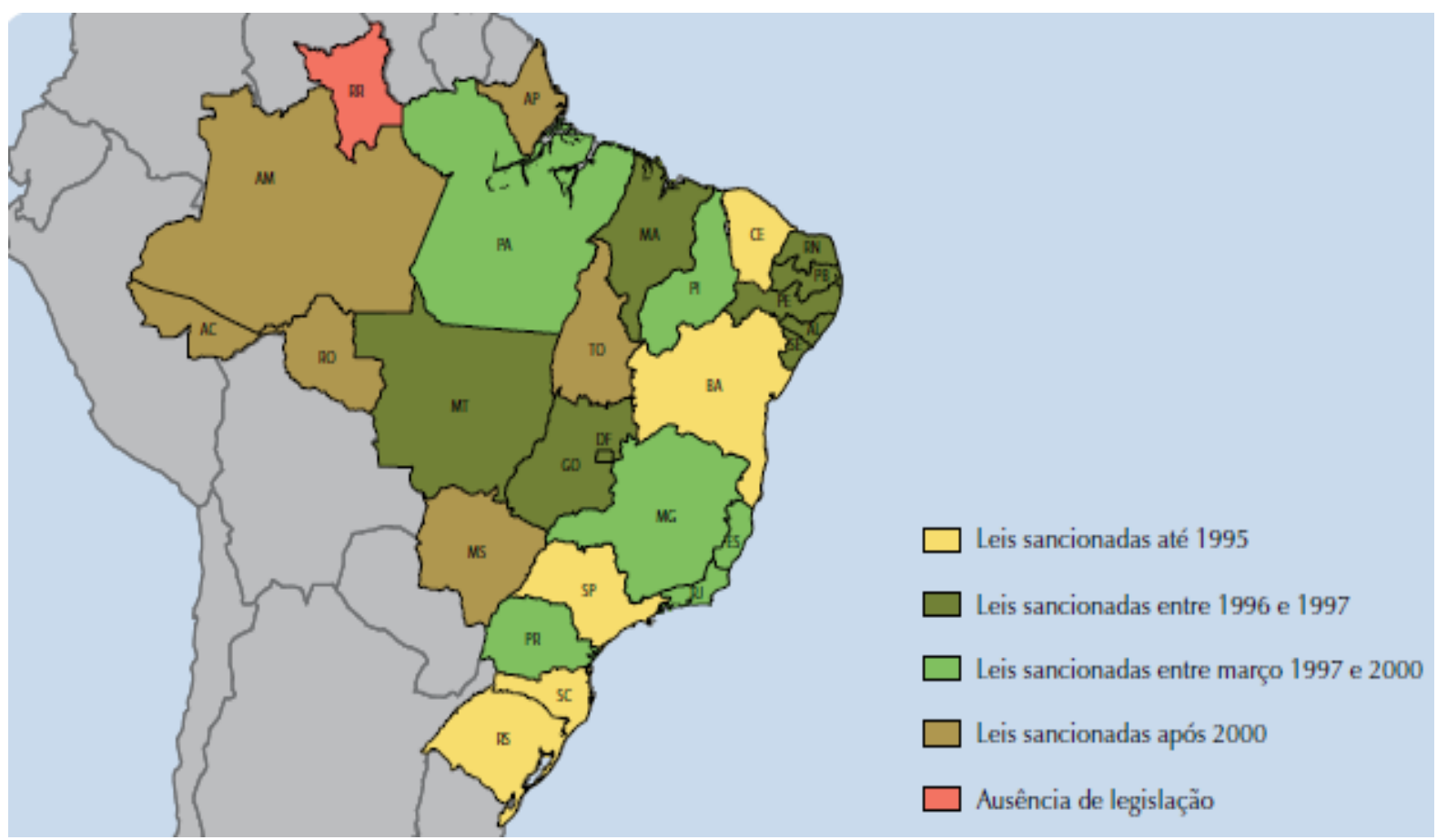

Figura 9.1: Síntese histórica das legislações estaduais de recursos hídricos no Brasil Fonte: GEO Brasil (2007)

E ao se considerar o arcabouço jurídico constitucional existente, bem diferente de outros países (MELLO; THEODORO, 2009; MOULAERT et al., 2005), a organização política e administrativa brasileira tem como seus constituintes a União (pessoa jurídica de direito público interno), os Estados-membros, o Distrito Federal e os municípios (VEIGA; MAGRINI, 2013). Vale salientar que são todos dotados de autonomia, ou seja, possuem poder de organização política, administrativa, tributária, orçamentária e institucional, tendo seu poder limitado pela Constituição Federal (ANA, 2006 e 2011). Isto significa que são autônomos, porém não independentes, uma vez que autonomia é antes um conceito político do que jurídico.

Ao contrário, a tomada de decisões no campo do gerenciamento hídrico é em si interdependente e está ligada ao arranjo político e institucional para funcionar de acordo com os preceitos legais de cada época. Até porquê, cabe destacar que a Lei Orgânica do Município não tem estatura constitucional, mesmo sendo prevalecente às outras leis ou normas municipais contrárias a si (JÚNIOR, 2006), e fica subjugada às determinações de âmbito das macro políticas públicas e jurídicas. 
Minas Gerais, por exemplo, foi um dos primeiros Estados a incluir na agenda pública e política algum mecanismo legal sobre o tema hídrico, sendo que em 1994 foi oficializada a Lei Estadual n 11.504, que determinava a elaboração do Plano Estadual de Recursos Hídricos (PERH). Mais adiante esta lei foi substituída pela Lei Estadual $\mathrm{n}^{\circ} 13.199$, que continua em vigor atualmente, principalmente por indicar a formação tanto da política (PERH) quanto do sistema (SEGRH) estadual de gerenciamento do tema, sendo o Instituto Mineiro de Gestão das Águas (IGAM) o órgão gestor, criado em 1997 (IGAM, 2015).

Este possui vinculação direta com a Secretaria de Estado de Meio Ambiente e Desenvolvimento Sustentável (SEMAD), que é uma autarquia estadual, ou seja, tem vinculação com o direito administrativo e com a administração pública indireta enquanto entidade que tem como objetivo o desempenho de atividades de gestão de forma descentralizada, porém passível de fiscalização e tutela do Estado. Melhor, é uma entidade autônoma de patrimônio próprio, com finalidade de planejamento e execução de ações de interesse coletivo ou estatal (JÚNIOR, 2006).

Assim, considerado como um responsável direto pela impossibilidade de novas interações institucionais, o campo jurídico tem sido cada vez mais analisado sob o ângulo de suas oportunidades para integração e descentralização institucional (VEIGA; MAGRINI, 2013). Ao se estudar quais os possíveis fatores que ajudariam o gerenciamento hídrico a avançar em relação à resolução de problemas (papéis dos participantes, planejamentos, etc), o trabalho visualiza que a dimensão legal é mais do que uma determinação e sim um dos elementos de gestão (MENEGAT, 2002), com destaque para o incremento da participação social e política local. Esse cuidado se torna fundamental quando se considera a realidade legal brasileira onde o caráter federativo imputa decisões em escalas diferentes e onde o princípio da subsidiariedade deve ser abalizado (GRANJA e WARNER, 2006).

\subsection{MÉTODOS}

Mesmo sendo uma análise sobre os aspectos legais e institucionais sobre a gestão de recursos hídricos em uma bacia hidrográfica específica, a pesquisa realizada se pautou pela interseção de métodos que possibilitassem o avanço da investigação sobre o tema. Por um lado, a pesquisa se utilizará do conjunto legal-institucional vinculado com a gestão de recursos hídricos, direta ou indiretamente vinculado ao tema (como planos diretores, uso do solo, 
institucional etc), na medida em que eles podem favorecer ou distanciar a atuação integrada e descentralizada do CBHRV.

Por outro, haverá a utilização da série de entrevistas realizadas (26) com as principais lideranças relacionadas, direta ou indiretamente, com a gestão de recursos hídricos no Rio das Velhas (a envolver especialistas, acadêmicos, líderes locais e representantes institucionais), a partir de uma perspectiva metodológica de triangulação de métodos qualitativa.

De maneira detalhada, essa tríade se estabelece enquanto combinação de elementos interdependentes de análise onde se sobressaem:

1) "observação participante": advinda da participação, via observação, de diversos momentos, eventos e cotidianos dos organismos de bacia vinculados ao CBHRV, tal como o próprio, sua agência de água, seus órgãos vinculantes e afins;

2) "análise de conteúdo": que se faz a partir da exploração qualitativa das informações que são geradas diretamente pelos indivíduos pesquisados via técnica de entrevistas face a face que podem revelar mais do que dados comumente catalogados (BARDIN, 1994);

3) "análise documental" = procedimento de coleta, primária e secundária de informações que sejam vinculadas ao objeto de estudo a partir de documentação oficial e/ou formal, direta ou indireta, anteriores e recentes, sob o prisma das políticas públicas e gestão institucional.

Essa composição estratégica de procedimentos se justifica na medida da complexidade que é se estudar processos de formação ou consolidação de práticas de gerenciamento integrado a partir de preceitos jurídicos e institucionais. Objetivamente, há aqui o emprego de metodologia de cunho qualitativo, onde aos fatores tradicionais de identificação de dados são agregadas as interpretações construídas e reveladas pelas lideranças escolhidas e entrevistadas.

Foram escolhidas na medida em que representam de forma clara alguma relação direta ou indireta com o comitê, sua agência, órgão de gestão ambiental ou de pesquisa; e entrevistadas enquanto técnica de coleta de dados qualitativa e de resposta aberta, a partir de perguntas semiestruturadas. Com isso se visou minimizar possíveis desvios de análise que fossem realizados a partir unicamente de uma única fonte e transmissão de informações. Tal como 
salienta CAMPOS (2004), para um melhor estudo que envolva a análise de conteúdo, a escolha do método e da técnica a ser empregada em uma pesquisa merece muita atenção e cuidado, principalmente pelo fato desta análise envolver a busca dos sentidos possíveis de um ato dentro de um dado contexto.

Como se trata da análise e discussão de um campo jurídico, um ponto importante de se colocar é que também há uma tríade a se considerar na gestão ambiental na federal brasileira, que é a de que Estado Federal, Estados-Membros e Municípios compõe as esferas de governo, o que é considerado como uma inovação legal (GRANJA e WARNER, 2006). Isto se deve ao fato de, ao menos teoricamente, favorecer a interação e a subsidiariedade das decisões jurídicas e institucionais sobre meio ambiente. Essa é possivelmente mais uma potencialidade na questão de se estabelecer uma interpelação de métodos para se poder entender melhor o tema.

\subsection{RESULTADOS E DISCUSSÃO}

Ao se analisar jurídica e institucionalmente os processos de gestão hídrica pelo estudo de caso do CBHRV, sob a ótica da implantação de processos de gestão participativa gestão (MENEGAT, 2002), valeria se definir que a gestão participativa não é (e nem poderia ser) o mesmo que governo. Este possui um caráter referencial de autoridade formal, de poder de comando e controle público por parte do Estado, em um dado período, em um dado contexto e em um arranjo institucional próprio. Igualmente, a compreensão de como se dão as principais restrições e possibilidades de melhoramento no modelo de gestão em andamento na bacia hidrográfica do Rio das Velhas deve se remeter, principalmente, às determinações legais da Constituição Federal de 1988 (GRANJA e WARNER, 2006).

Esta se destaca por adotar o modelo de "Estado Democrático de Direito", com forma de governo republicana (base na soberania popular interna e externa), presidencialista e com uma proposta de separação harmônica e interdependente entre os poderes legislativo, judiciário e executivo. Mais ainda, esta Constituição Federal, a sétima a ser exercida no país, teve como princípio o resgate dos princípios da cidadania, da organização social e do aumento da representação política que, teoricamente, teria maior possibilidade de participação direta e representativa na agenda social gestão (MENEGAT, 2002).

Programa de Pós-graduação em Saneamento, Meio Ambiente e Recursos Hídricos da UFMG 
Uma das formas dessa participação democrática e descentralizada acontecer seria criada também pela inclusão dos municípios brasileiros como entes que compõem o modelo federativo e com ordenação administrativa através de instauração de lei orgânica ao nível de seu território de atuação.

Mesmo com a existência de legislação pertinente aos recursos hídricos, principalmente de forma nacionalizada e federalizada, com o Código das Águas de 1934 (Decreto n 24.643, de 10 de julho de 1934), o tema só foi ser incorporado de forma mais ampla a partir da promulgação da nova Constituição Federal, fruto de um processo histórico de redemocratização das políticas públicas no país (NEDER, 2002; VEIGA; MAGRINI, 2013; FREY, 2000). Nela, a questão hídrica encontra respaldo em vários de seus artigos, com destaque para o Título VIII, Capítulo VI, Art. 225, que trata especificamente sobre o tema “Do Meio Ambiente". Por conseguinte, é dada uma nova dinâmica às relações institucionais relativas à gestão de recursos hídricos no país que, em efeito, se transformam em leis estaduais e leis orgânicas municipais com o devir dos anos, tal como se salienta no Quadro 9.1.

Ou seja, foi todo um processo de busca pela descentralização institucional onde a participação do maior número de atores sociais foi buscada e onde a gestão participativa, como meio de estabelecimento de novos arranjos sociais, expressos além de mecanismos de coerção, fosse realizada (GONÇALVES, 2006; (GRANJA e WARNER, 2006).).

Por outro lado, há aqui uma possível disparidade de ordem temporal que merece ser analisada: enquanto o arcabouço jurídico do país determinada a incorporação de novos valores, instituições e procedimentos administrativos, econômicos, financeiros e legais, por outro a sociedade civil, o setor privado e o próprio Estado se encontravam em condições diferenciadas de entendimento, atuação e perspectivas sobre o tema.

Isto se traduziu em processos atropelados de constituição de organismos de bacia, fosse na constituição de comitês e agências de bacia hidrográfica ou mesmo na criação de autarquias, secretarias e afins em todos os níveis da estrutura pública estatal do país. Em relação aos diversos temas associados com a questão da água, tal como o saneamento (REZENDE e HELLER, 2008; BRITO et al, 2012), drenagem (BATISTA e NASCIMENTO, 2002), resíduos sólidos (THEODORO et al., 2013), uso e ocupação do solo etc, acabou por ocorrer a 
criação de agendas públicas sobrepostas e com desafios legais de difíceis soluções em curto prazo (como na questão da gestão de áreas urbanas, por exemplo - BONTEMPO et al., 2012).

Quadro 9.1: Avanços na gestão hídrica após a Constituição Federal de 1988

\begin{tabular}{|c|c|}
\hline Período & Fato e Característica \\
\hline $\begin{array}{l}\text { Pós-Constituição de } 1988 \\
\text { e Pré Lei Nacional }\end{array}$ & $\begin{array}{l}\text { 7) Grande dinâmica nos debates sobre a gestão de recursos } \\
\text { hídricos; } \\
\text { 8) Advento de diversas legislações estaduais: São Paulo, Ceará, } \\
\text { Rio Grande do Norte e Paraíba, dentre outras; } \\
\text { 9) Criação do Sistema Estadual de Recursos Hídricos em Minas } \\
\text { Gerais, Lei no 11.504/94; } \\
\text { 10) Reformulação do Conselho Estadual de Recursos Hídricos em } \\
\text { Minas Gerais (1995); } \\
\text { 11) Reformulação do Comitê da Bacia do Rio Paraíba do Sul } \\
\text { (CEIVAP), em março de 1996; } \\
\text { 12) Lei Nacional n }{ }^{\circ} 9.433 \text {, sancionada em } 08 \text { de janeiro de } 1997 .\end{array}$ \\
\hline Pós Lei Nacional & $\begin{array}{l}\text { - Novas legislações estaduais: Pernambuco (1997), Espírito Santo } \\
\text { (1998), Minas Gerais, Paraná e Rio de Janeiro (1999); } \\
\text { - Criação da Secretaria de Recursos Hídricos do Ministério do } \\
\text { Meio Ambiente, que desde } 95 \text { funcionava sob regime de } \\
\text { medida provisória; } \\
\text { - Avanços substantivos no Estado do Ceará; } \\
\text { - Lentidão relativa no âmbito da União, entre } 1997 \text { e } 2000 \text {. }\end{array}$ \\
\hline $\begin{array}{l}\text { Pós-criação da Agência } \\
\text { Nacional de Águas }\end{array}$ & $\begin{array}{l}\text { - Recuperação relativa da dinâmica em rios de domínio federal, } \\
\text { com avanços pontuais na bacia do Paraíba do Sul, em especial, } \\
\text { com a aprovação da Lei no } 10.881 / 04 \text { e assinatura do Contrato } \\
\text { de Gestão com a AGEVAP; } \\
\text { - Dinâmica específica introduzida nos Estados do Nordeste, a } \\
\text { partir do PROÁGUA/Semi-árido; } \\
\text { - Retrocessos relevantes no caso da bacia do rio São Francisco, já } \\
\text { que, não obstante a elaboração do Plano de Bacia, os embates } \\
\text { judiciais envolvendo o Projeto de Interligação de Bacias, e do } \\
\text { desmonte do Sistema do Paraná. }\end{array}$ \\
\hline
\end{tabular}

Fonte: ANA, 2006

E como se verifica tanto na Quadro 9.1 como na jurisdição pertinente, há uma tendência em se favorecer a gestão ambiental e a gestão hídrica, especificamente, ao nível local, de forma a fortalecer os municípios brasileiros (em número de 5.570 até o início de 2015) a lidarem com o assunto de forma mais corrente. E os municípios, por serem entidades federativas com personalidade jurídica de direito público interno e dotado de autonomia, com competência legislativa e tributária e sendo considerados na jurisprudência como entes federativos, assumem uma importância até naquele momento pouco desenvolvida junto ao campo da gestão descentralizada. 
Porém, tal delegação demonstra precisar ser mais trabalhada, inclusive pelo fato de que, constitucionalmente, os rios, assim como lagos e qualquer corrente de água são de domínio da União (Art. 20), que pode sobre os mesmos legislar privativamente (Art. 22).

A própria Lei Federal n ${ }^{\circ}$ 9.433, que institui a Política Nacional de Recursos Hídricos (PNRH) foi citada nas entrevistas com lideranças como legislação que falhou ao não considerar de forma particular o papel dos municípios dentro do sistema de gestão e sim como mais um componente do mesmo. O resultado disso pode ser analisado como um consequente afastamento dos municípios dos processos de tomada de decisão até bem recentemente, quando os recursos da cobrança (IGAM, 2015) começaram a ser aplicados para projetos hidroambientais e planos de saneamento municipais.

Isso têm significado um poder de tomada de decisão sobre os recursos hídricos com grande base na agenda política pública federal estatal e, subsidiariamente, nos governos estaduais. Em termos práticos a capacidade de intervenção estatal se coloca de forma destacada na determinação das ações a serem tomadas sobre os recursos hídricos como, por exemplo, em ações de planejamento, execução e gestão. Um exemplo mais específico sobre isso é a criação, em 2000, da Agência Nacional de Águas (ANA), que é a agência reguladora responsável pelo gerenciamento dos recursos hídricos brasileiros e que é citada como a principal definidora das ações a serem realizadas pelo Estado.

Como se percebe no Quadro 9.2, inclusive, a gama de instrumentos de gestão de base jurídica (decretos, leis, planos, resoluções, portarias etc) na federação brasileira faz com que a forma de resposta dos entes federados (27 unidades administrativas, sendo 26 os Estados-Membros e o Distrito Federal) seja muito diferenciada. Isso reflete, direta ou indiretamente, possíveis disparidades existentes entre o campo institucional-jurídico e os processos de gestão ao nível de bacia hidrográfica.

Quer dizer, isso sinaliza que os níveis de governabilidade (exercício de poder ao plano do Estado) e de governança (aqui compreendida como acordos e arranjos institucionais formas/não formais e interacionais) vão depender muito das condições sistêmicas e do desenho institucional de cada Estado-Membro (GONÇALVES, 2006; CUNHA; THEODORO, 2014) para serem realizados. 
Quadro 9.2: Instrumentos de gestão de recursos hídricos nas unidades federativas brasileiras

\begin{tabular}{|c|c|c|c|c|c|c|c|c|c|c|c|c|}
\hline \multirow{2}{*}{\multicolumn{2}{|c|}{$\begin{array}{c}\text { Região/ } \\
\text { Unidades } \\
\text { Federadas }\end{array}$}} & \multicolumn{11}{|c|}{ Instrumentos } \\
\hline & & PERH & PRH & Enq. & Outorga & Penal. & Cob. & Rat. & CM & Com. & Fundo & SIRH \\
\hline \multicolumn{13}{|c|}{ Região Sul } \\
\hline \multicolumn{2}{|c|}{ Rio G. do Sul } & & & & $\bar{D}$ & & & & & & $\bar{L}$ & \\
\hline \multicolumn{2}{|c|}{ Santa Catarina } & & & & D & & & & & & D & \\
\hline \multicolumn{2}{|l|}{ Paraná } & & & & $\mathbf{D}$ & & D & & & & & \\
\hline \multicolumn{13}{|c|}{ Região Sudeste } \\
\hline \multicolumn{2}{|c|}{ São Paulo } & $\mathbf{L}$ & & & D & D & L/D & & & & D & \\
\hline \multicolumn{2}{|c|}{ Rio de Janeiro } & & & & $\mathbf{P}$ & & $\mathbf{L}$ & & & & $\bar{D}$ & \\
\hline \multicolumn{13}{|c|}{ Espírito Santo } \\
\hline \multicolumn{2}{|c|}{ Minas Gerais } & $\bar{D}$ & $\bar{D}$ & $\bar{D}$ & $\mathbf{P}$ & $\bar{D}$ & D & D & D & & $\bar{D}$ & $\bar{D}$ \\
\hline \multicolumn{13}{|c|}{ Região Centro-Oeste } \\
\hline \multicolumn{13}{|c|}{ Mato Grosso } \\
\hline \multicolumn{13}{|c|}{ Mato G. do Sul } \\
\hline \multicolumn{2}{|l|}{ Goiás } & & & & $\mathbf{R}$ & & & & & & & \\
\hline \multicolumn{2}{|c|}{ Distrito Federal } & & & & D & & & & & & & D \\
\hline \multicolumn{13}{|c|}{ Região Nordeste } \\
\hline \multicolumn{2}{|l|}{ Bahia } & & & & $\bar{D}$ & & $\bar{D}$ & & & & & \\
\hline Sergipe & & & & & D & & & & & & D & \\
\hline Alagoas & & & & & D & & & & & & & \\
\hline Pernam & & $\mathbf{L}$ & & & & & & & & & & \\
\hline Paraíba & & & & & $\bar{D}$ & & & & & & $\bar{D}$ & \\
\hline Rio G. $\mathrm{c}$ & Norte & $\bar{L}$ & & & $\bar{D}$ & & & & & & D & \\
\hline Ceará & & & & & D & & D & & & & D & \\
\hline Piauí & & & & & D & & & & & & & \\
\hline Maranh & & & & & & & & & & & & \\
\hline & & & & & Regi & Norte & & & & & & \\
\hline Pará & & & & & & & & & & & & \\
\hline Amazon & & & & & & & & & & & & \\
\hline Tocanti & & & & & $\mathbf{P}$ & & & & & & & \\
\hline Amapá & & & & & & & & & & & & \\
\hline Roraim & & & & & $\mathbf{P}$ & D & & & & & D & \\
\hline Acre & & & & & & & & & & & $\mathbf{L}$ & \\
\hline & Ausên & instrume & nas leis & & & & & & & & & \\
\hline & Presen & instrume & em lei & & & & & & & & & \\
\hline & Em im & ação & & & & & & & & & & \\
\hline SIRH & Sistem & Informaçõ & obre $\mathrm{Re}$ & $\operatorname{rsos~H}$ & $\cos$ & & & & & & & \\
\hline PERH & Plano 1 & ual de Re & os Hídr & & & & & & & & & \\
\hline PRH & Plano & cursos Hí & os de ba & a hidro & ifica & & & & & & & \\
\hline Enq. & Enqua & ento de co & s de águ & em clas & , segundo $\mathrm{I}$ & s prepor & rantes & água & & & & \\
\hline Penal. & Penali & & & & & & & & & & & \\
\hline Cob. & Cobrar & elo uso de & ursos hí & & & & & & & & & \\
\hline Rat. & Rateio & astos das c & $\mathrm{s}$ de usc & últiplo & & & & & & & & \\
\hline CM & Compe & ão a muni & & & & & & & & & & \\
\hline Com. & Outras & las de com & ssação & & & & & & & & & \\
\hline Fundo & Fundo & dual de $\operatorname{Re}$ & sos Híd & os, par & plicação em & acia hidr & ráfica & & & & & \\
\hline $\mathbf{P}$ & Portari & & & & & & & & & & & \\
\hline D & Decret & & & & & & & & & & & \\
\hline $\mathbf{R}$ & Resolu & & & & & & & & & & & \\
\hline $\mathbf{L}$ & Lei & & & & & & & & & & & \\
\hline
\end{tabular}

Fonte: ANA (2007) 
Ao se analisar comparativamente, por exemplo, percebe-se a utilização de decretos (ou seja, que regulamentam as leis e dispõem sobre a administração pública em termos de sua organização) como o principal instrumento jurídico para a gestão, sendo Minas Gerais um exemplo claro por esta opção. O Estado, ao mesmo tempo, tem destaque por possuir um arcabouço legal que praticamente nenhum outro tem, com grande vinculação aos instrumentos de gestão tradicionalmente estabelecidos (cobrança, plano diretor, outorga, sistema de informações, enquadramento), diferentemente de alguns Estados que não tem estrutura implantada (ALMEIDA et al., 2013).

Por exemplo, a outorga (ou seja, a concessão pública para uso múltiplo dos recursos hídricos em uma dada bacia hidrográfica de um dado Estado-Membro ou da União) é o instrumento que mais se destaca. Ela é o fator essencial de regulamentação legal do uso hídrico a partir do enquadramento e que, consequentemente, permite a realização dos cálculos necessários para o estabelecimento da cobrança (IGAM, 2015) por este uso citado e requerido. Ela é fundamental para a instalação de empreendimentos produtivos e para a regulação ambiental e hídrica consultiva e não-consultiva. De forma geral, se percebe que o arranjo jurídico é muito amplo para se realizar a gestão de forma simplificada e em apenas uma esfera de decisão.

$\mathrm{Na}$ verdade, ao se analisar o aspecto jurídico e hídrico como um todo, cabe salientar que a legislação hídrica versa basicamente sobre direitos de propriedade (acesso livre; propriedade comum; propriedade privada; propriedade estatal), o que significa que, com o aumento de usos múltiplos da água, aumenta-se também a possibilidade dos conflitos. Essa realidade, inclusive, tem sido cada vez mais verificada no país e em seus Estados da região sudeste (Rio de Janeiro, Espírito Santo e, particularmente com mais intensidade, em São Paulo e Minas Gerais) e nordeste, principalmente nas bacias do Rio Paraíba do Sul e do Rio São Francisco, respectivamente. Tanto que no início do ano de 2015 assumiram esses Estados publicamente a existência de crises hídricas de captação, retenção e abastecimento por seus governos.

Sendo assim, os princípios para que aconteça a efetividade da gestão institucional passam por aspectos de transparência nas negociações, inclusão do número maior possível de partes interessadas (a se considerar que não se incluem todos ao mesmo tempo e em mesmas condições), coerência e ética nas decisões tomadas via processos que demandam equidade consultiva e deliberativa. Percebe-se que estas premissas encontram condições apropriadas principalmente a partir da consideração da bacia hidrográfica com unidade de planejamento,

Programa de Pós-graduação em Saneamento, Meio Ambiente e Recursos Hídricos da UFMG 
uma vez que propicia um recorte social e geográfico mais definido, de maior interação entre os atores e com normatização específica.

Melhor, é uma condição tanto da jurisprudência a ser indicada em cada local e condição, como também do desejo institucional de gestão que se deseja construir e implantar. Isto tendo sempre em vista aos marcos regulatórios propostos e através do incentivo a espaços de consenso como, por exemplo, os organismos de bacia como um todo (a se incluir também os municípios) e aos comitês em particular (THEODORO, 2002).

Um exemplo da importância disso pode ser identificado que em 2014 foi apresentado no Senado Federal brasileiro um Projeto de Lei do Senado - PLS 288/2014, de 16 de outubro de 2014 - que pretende (pois ainda se encontra em discussão) alterar a Lei Federal 9.433/97 com a proposta de incluir os CBHs na discussão sobre a mudança da vazão de seus corpos de água (taxa de escoamento hídrico através de uma dada tubulação em uma dada unidade de tempo) SENADO FEDERAL (2015). Visa-se com isso possibilitar uma utilização mais ampla dos usos múltiplos que eram realizados e que estariam muito vinculados aos interesses pela segurança energética, basicamente, de acordo com os levantamentos das entrevistas e de observação participante.

E caso tal alteração aconteça, os comitês de bacia hidrográfica terão a competência de decidir sobre as alterações de vazão outorgada de reservatórios regularizadores existentes em suas bacias vinculantes. Isso se coaduna com o que foi também identificado por estas duas metodologias das afirmações de que a gestão dos recursos hídricos no país e nos comitês ainda é feita de cima para baixo (“topdown") e cartorial.

Melhor, seria feita basicamente a partir de regulamentos e não de processos políticos coletivos desde a base, populações locais e municipais da bacia. Mas cabe lembrar também que a infraestrutura institucional dos comitês em geral tem sido constantemente colocada em questão e que os novos desafios e responsabilidades que porventura possam lhes ser determinadas talvez sobrecarreguem a capacidade de intervenção dos mesmos. No caso da determinação de vazão, que é um procedimento bastante técnico e que demanda conhecimento prévio, provavelmente algo que nem todos os municípios possuam em seus quadros de pessoal, uma vez, de modo geral, há uma baixa capacitação em recursos hídricos no país (IPEA, 2012). Em todo caso, tal proposta também pode ser encarada como uma possibilidade real de inovação para futuras ações de melhorias na gestão.

Programa de Pós-graduação em Saneamento, Meio Ambiente e Recursos Hídricos da UFMG 
Já no caso específico do CBHRV, por exemplo, e de acordo com as entrevistas realizadas com as lideranças do setor, há várias restrições para que tal interação ocorra do modo como previsto e que os municípios assumam melhor suas possíveis participações. Elas passam por fatos como:

1) De que os municípios não entenderiam bem ainda o seu papel dentro da estrutura de gestão de recursos hídricos e, consequentemente, não exerceriam suas titulares à mesma medida;

2) Não conheceriam bem os instrumentos e o gerenciamento hídrico como um todo, sem identificarem claramente a importância do comitê, subcomitês, câmaras técnicas e diretoria colegiada, por exemplo;

3) O CBHRV, por se encontrar desmobilizado e sem grandes recursos para investimentos em infraestrutura, não daria o apoio necessário para as prefeituras poderem atuar;

4) Ao mesmo tempo em que a gestão é territorial, por bacia hidrográfica, se teria de pedir constante apoio formal e não formal às prefeituras para se evitar conflitos institucionais e sociais.

Para compensar um pouco esse distanciamento entre o nível estatal público estadual e o municipal, o CBHRV incorporou a criação de uma representação quadripartite dentro de sua estrutura, que é composta por 28 membros titulares divididos em poder público estadual, poder público municipal, sociedade civil e usuários (setor privado). Tal medida se encontra dentro das determinações legais e administrativas que são usualmente especificadas ao modelo de gestão por comitê, com atribuições consultivas, propositivas e deliberativas, como especificada no Quadro 9.3.

O objetivo foi o de se tentar dar maior representação ao nível local da bacia, uma vez que, como dito em várias entrevistas, Estado e municípios não pensam de forma igual e, por isso, devem estar separados enquanto membros do comitê. O problema de tal perspectiva e que identificada na análise documental e na análise de conteúdo é que os níveis de capacidade de intervenção política e institucional de ambos (Estado e municípios) são mesmo muito diferenciados a depender do tema (planos diretores, por exemplo), o que não facilita que atuem conjuntamente para a descentralização institucional-legal de forma integrada. 
Quadro 9.3: Atribuições determinadas aos Comitês de Bacia Hidrográfica (CBHs)

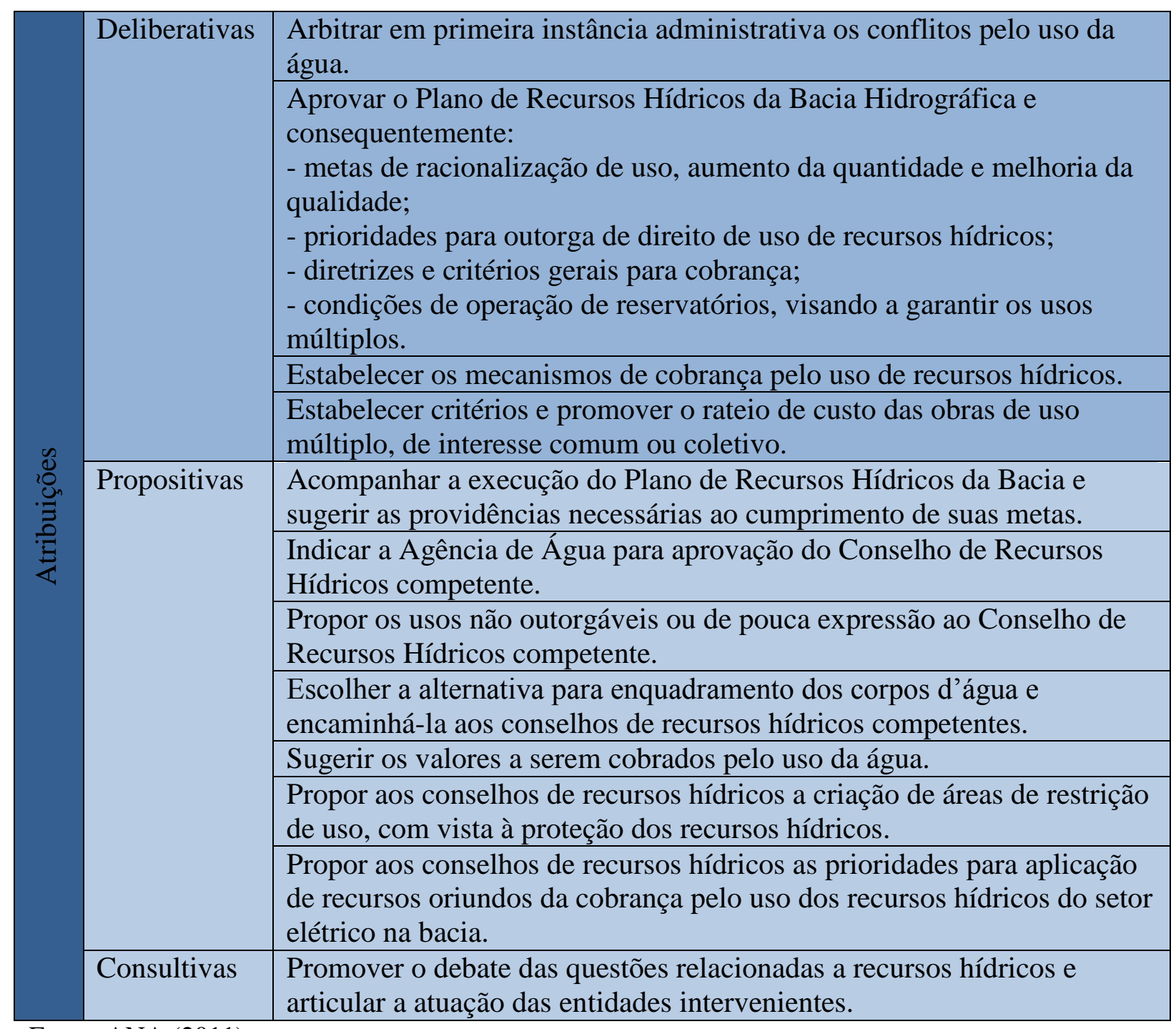

Fonte: ANA (2011)

Outra ação legal que também foi tomada se deu no fomento para a criação de subcomitês de bacia hidrográfica, que são em número de 13 atualmente (2015), pela Deliberação Normativa (DN) CBHRV nº 02 de 2004. Com isto se buscou se assegurar maior descentralização, ao menos, das discussões consultivas e propositivas, uma vez que somente o CBHRV em si pode deliberar sobre ações no território da bacia. Essa medida tem foi bem avaliada na pesquisa de campo e nas entrevistas, pois possuem uma tendência de serem ampliadas no decorrer da bacia e têm demonstrado uma proximidade com as populações locais.

Em mesmo sentido a reconfiguração da bacia hidrográfica em Unidades Territoriais Estratégicas (UTEs), pela DN $\mathrm{n}^{\circ} 1$ de 2012, se mostrou como proposta para facilitar o planejamento de atuação do comitê no território a partir das características semelhantes destes 
e não apenas na definição administrativa e jurídica em prática. Uma complementa a outra no sentido de poder delimitar os níveis de atuação dos subcomitês e das comunidades locais da bacia e para qualificar mais a gestão como espaço multinível de participação. Porém a criação de UTEs não encontrou tanto retorno tanto em campo quanto na pesquisa documental econômica e financeira e nem nas entrevistas. Pois, mesmo que teoricamente sejam consideradas como um avanço, na prática o comitê não teria ainda estrutura de tornar essa deliberação real e sua validade em termos legais e operacionais foi colocada em questão pelos operadores do sistema.

Ao mesmo tempo, essa iniciativa em termos da tomada de decisões de caráter legal e institucional não necessariamente pode ser traduzida como avanço no comitê enquanto um organismo de bacia. A se pensar nos preceitos para o estabelecimento de práticas de gestão institucional, tais como participação, transparência e espaços multiníveis de interações formais e não formais (BENSON et al, 2015), o caminho ainda não estaria consolidado, de acordo com as pesquisas de campo e análise de conteúdo. Os diálogos entre as partes são mensurados atualmente muito mais pela capacidade de liberação ou não de outorgas ou na capacidade de se implementar mecanismos de cobrança, como também na possibilidade de captação de recursos pelas prefeituras participantes do CBHRV (IGAM, 2015).

Esses movimentos institucionais foram citados como exemplos de que há um utilitarismo na ação estatal do arcabouço legal mais do que a incorporação de valores de gestão participativa, como ser descentralizada e participativa de fato e não de direito. Ou, como verificado em entrevistas, as vontades políticas e recursos institucionais (econômicos, financeiros e legais) conjugados é que seriam mais importantes para a gestão do apenas um deles somente a agir. Essa posição faz coro aos relatos das lideranças de que eventualmente quem define a pauta da agenda institucional da água em Minas Gerais e no CBHRV é a ANA, que tem sido cada vez mais presente no acompanhamento do tanto do próprio como de sua agência.

Outro ponto levantado pelas lideranças seria de que mesmo há uma distância, maior ou menor a depender do ponto de vista do autor e da instituição, entre lei e prática, uma vez que a legislação previu mecanismos (comitês, agências, conselhos, dentre outros), mas o quanto isto influencia diretamente na gestão ainda estaria longe de ser alcançado. Esta se situaria além de uma abordagem tecnocêntrica ou burocratizada (BANCO MUNDIAL, 2003) que se mostra insuficiente para dar conta de uma realidade multifacetada que demanda processos mais 
democráticos para participação e deliberação (BRITO et al., 2012), direção na qual a gestão institucional busca existir. Ou seja, mesmo que haja todo um conjunto de normatizações não quer dizer que, necessariamente, haverá maior interação entre os atores sociais e institucionais participantes. Mais, só instrumentos de gestão não asseguram mudanças sociais e institucionais e, de acordo com as análises de conteúdo e documental, da forma e no estágio em que se encontra o modelo atual em termos jurídicos e institucionais ainda não se confirmou como suficientemente cristalizado enquanto sistema de gestão das águas ou de desenvolvimento sustentável.

\subsection{CONCLUSÕES}

Como indicado no início deste texto, o objetivo do trabalho foi o de se tentar identificar restrições e possibilidades ao modelo de gestão participativa e descentralizada sob o enfoque legal. Isto posto, foi possível se verificar a existência de lacunas entre a teoria da legalidade presente na gestão e sua prática, seja no CBHRV ou em suas entidades vinculantes. Esses descompassos devem ser entendidos, a partir da triangulação de métodos colocada em prática, a partir de um movimento de tentativa de integração e gestão participativa que está a se formar e que tem obtido contornos diferentes de interpretação pelos segmentos componentes do comitê.

Entre as disparidades existentes entre o campo institucional e jurídico e os processos de gestão ao nível do CBHRV e da bacia hidrográfica como um todo, pode-se salientar o desconhecimento do sistema de gestão, seja em questões jurídicas ou administrativas, a falta de um planejamento integrado e de longo prazo que consiga refletir as demandas sociais da bacia, assim como a ainda pouca adesão tanto das populações da mesma e do fato de que as regras para participação em na proposta do sistema descentralizado não estão claras aos seus participantes.

Já como diferenciais de iniciativas institucional e legal o trabalho verificou que as deliberações normativas se orientaram para o fortalecimento da gestão descentralizada via subcomitês, que são considerados como um avanço neste aspecto da gestão hídrica. Outrossim, o direcionamento dos recursos pelo uso de recursos hídricos para o estabelecimento de projetos e afins junto aos municípios foi muito considerado nas entrevistas e pesquisa de campo realizadas. Porém, fato recorrente é que o sistema como um todo ainda é precário para a demanda existente, mesmo como arcabouço jurídico estabelecido. Esse 
distanciamento entre a teoria jurídica e a prática administrativa foi também citado de forma recorrente.

Isto é, a partir da metodologia aplicada, a dimensão legal se mostrou insuficiente como mecanismo de direcionamento da gestão ao modelo descentralizado e participativo. Isto, porém deve ser entendido dentro de uma proposta maior que foi muito citada pelas lideranças de que somente com a incorporação do arcabouço jurídico em um modelo de mais articulado e mais interinstitucional. O que é identificado é que a gestão descentralizada e integrada em sua ótica legal e em uma perspectiva de gestão participativa é mais latente do que potente. $\mathrm{Ou}$ seja, ela por vários momentos não se manifesta em toda a sua possibilidade, mas se mostra capaz de se desenvolver na medida em que circunstâncias contextuais sejam favoráveis.

O fato de que há um envolvimento na gestão local e um aporte de investimentos podem ser considerados exemplos disso, porém ainda há muito a ser consolidado. Até porquê, como diz um preceito do campo jurídico, "a lei só pode atuar quando é provocada"; cabe ao modelo de gestão institucional-legal, via organismos de bacia, demonstrar que tal pode ser uma realidade. E mais, que, ao conseguirem seus intentos, consigam também arcar com suas novas responsabilidades. O que ficou claro na pesquisa encaminhada foi, assim, que o modelo de descentralização e gestão de recursos hídricos sob o enfoque legal demanda ser continuamente repensado para dar conta de seus desafios institucionais colocados atualmente. 


\section{RECURSOS ECONÔMICOS-FINANCEIROS PARA A CONSTRUÇÃO DA GOVERNANÇA DOS RECURSOS HÍDRICOS. INSUFICIÊNCIAS, ASSIMETRIAS E OPACIDADES NA BACIA HIDROGRÁFICA DO RIO DAS VELHAS, MINAS GERAIS, BRASIL ${ }^{79}$}

\subsection{INTRODUÇÃO}

Considerada como uma das principais temáticas emergentes na gestão de recursos hídricos, a aplicação de recursos econômico-financeiros no nível de bacia hidrográfica ainda continua a ser um assunto que pode e deve ser aprofundado, visando ao seu aperfeiçoamento (SEPÚLVEDA et al., 2011). A formulação de políticas públicas específicas para o tema, assim como a institucionalização de procedimentos que possam dar maior eficiência aos processos de tomada de decisão para investimentos públicos, é uma demanda cada vez mais presente no cotidiano do sistema de gestão dessa área (CAMPOS et al, 2014). Nesse sentido, a identificação dessa discussão dentro do cenário do estado de Minas Gerais se torna aqui importante, primeiramente devido às suas características particulares.

Localizada na região central do Estado de Minas Gerais, a bacia hidrográfica do Rio das Velhas possui uma extensão de $801 \mathrm{~km}$ e com 51 municípios totalmente localizados em território mineiro, com uma área de drenagem de $29.173 \mathrm{~km}^{2}$, tendo como nascente o Parque Municipal das Andorinhas em Ouro Preto e como foz o Rio São Francisco, em Várzea da Palma. É uma bacia hidrográfica que tem uma de suas características principais o fato de que mais de $70 \%$ da sua população se encontra na Região Metropolitana de Belo Horizonte (RMBH), que é a capital do Estado. Nesta, o Rio das Velhas se destaca por ser um dos mais importantes mananciais de captação de água e atende diretamente aos municípios de Belo Horizonte, Nova Lima, Raposos, Sabará e Santa Luzia (ANA, 2009).

Consequentemente, os habitantes da RMBH, 4.843.316 milhões (IGAM, 2014(a)), utilizam de maneiras e intensidades variadas os recursos hídricos existentes e que, até 2008, não eram passíveis que qualquer tipo de controle pecuniário.

Como objeto de discussão nesse trabalho se tem justamente a dinâmica (arrecadação e aplicação de recursos) econômica-financeira na bacia hidrográfica do Rio das Velhas (e pelo seu respectivo comitê e agência de água) a partir da cobrança pelo uso dos seus recursos

\footnotetext{
79 Artigo enviado, revisado e aprovado para publicação na Revista Recursos Hídricos, Vol. 37, No 2, p. 47-63, 2016, da Associação Portuguesa de Recursos Hídricos (APRH), classificação Qualis B3, Engenharias I.
}

Programa de Pós-graduação em Saneamento, Meio Ambiente e Recursos Hídricos da UFMG 
hídricos, ocorrida em 2009 (IGAM, 2014(b); IGAM, 2014(c)). Ela foi regulamentada pela Deliberação Normativa CBH Velhas no 3/2009 e aprovada pelo Conselho Estadual de Recursos Hídricos (CERH) pela Deliberação CERH n 185/2009.

No caso específico de Minas Gerais, é cabível tentar compreender a complexidade da situação de uso deste recurso dotado de valor econômico enquanto insumo de diversas atividades produtivas (IGAM, 2014(d) e IGAM, 2014(e)), a partir da Figura 10.1. De acordo com IGAM (2014(f)), essa figura representa graficamente que no território mineiro há um percentual de $13 \%$ para o consumo humano, de $15 \%$ para o consumo industrial e bem maior, de $24 \%$ para finalidades de irrigação (IGAM, 2014 (f)).

E essa importância percentual relativa aos setores produtivos também é demonstrada no denominado "Plano Plurianual de Aplicação (PPA)", que é o instrumento de gestão existente, ao nível administrativo, para que projetos com finalidades diversas e com origem na bacia hidrográfica que captem recursos para infraestrutura ou formação técnica - ele é formalizado via Deliberação Normativa do próprio CBHRV, sendo o atual o do exercício de 2015 a 2017 , via $\mathrm{DN} \mathrm{n}^{\circ}$ 010, de 2014 (CBH VELHAS, 2014). Consequentemente, processos de governança que envolvem os usos múltiplos desses recursos hídricos, por via de múltiplos atores é um passo fundamental.

Nesse rol de finalidades a Figura 10.1 indica vários deles, com destaque para grandes usuários industriais diferentes, setor agropecuário, setor mineral e também consumo humano regular. Devem ser pensados, em termos de planejamento de curto e longo prazo, em consideração também a estes percentuais e usos consultivos e não consultivos dos vários segmentos.

Como se pode verificar na Figura 10.1, também, em termos das finalidades das outorgas concedidas em 2013, por número de outorgas, os maiores consumidores/captadores dos recursos hídricos não são as pessoas e sim os processos de produção variados. E essa variação tanto na disponibilidade quanto na demanda hídrica é um fator importante a ser considerado pelas políticas públicas, visto que, inclusive, conflitos sobre recursos hídricos já são uma realidade no próprio estado de Minas Gerais (MOREIRA et al, 2014). 


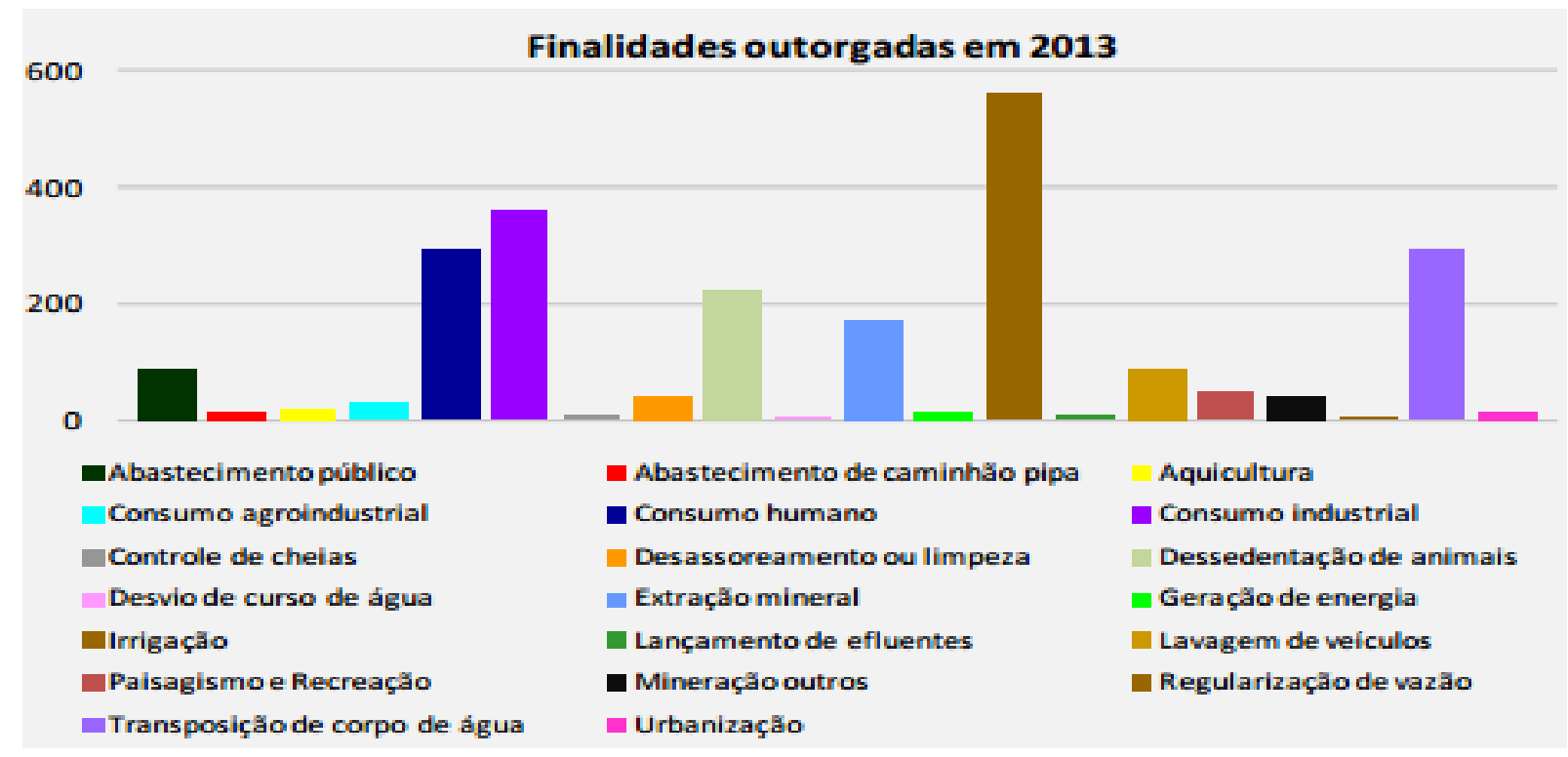

Figura 10.1: Finalidades outorgadas para uso de recursos hídricos em 2013, em MG Fonte: IGAM, 2014(a)

Visa-se neste trabalho se identificar as principais restrições e possibilidades que a aplicação de recursos econômico-financeiros possa ter gerado ao modelo de gestão pública participativa, descentralizada e integrada relativa aos recursos hídricos a partir do final da primeira década do ano 2000, da forma como é pretendida pela legislação vigente, nacional e estadual. Na mesma direção, objetiva-se tal análise a partir da perspectiva da construção de mecanismos que favoreçam ações de governança institucional e social na gestão, tais como a definição conjunta de aplicação de recursos da cobrança pelo uso dos recursos hídricos de forma mais consolidada, com maior participação pública.

É buscada aqui a verificação tanto das formas como têm sido realizados os recursos econômico-financeiros na bacia hidrográfica do Rio das Velhas e quais seus principais procedimentos e grupos de aplicações para o planejamento geral para a bacia em termos de suas possibilidades administrativas, tendo como recorte o período entre 2010 e 2014 de execução da cobrança.

E, de acordo com tais questões, parte-se do pressuposto de que, uma vez que a gestão econômico-financeira dos recursos hídricos da bacia hidrográfica do Rio das Velhas se dá através da sua agência executiva e a partir das deliberações do Comitê da Bacia Hidrográfica do Rio das Velhas (CBHRV), em bases administrativas e legais, forma-se um tipo de gestão participativa que que pode produzir assimetrias de poder e representação dentro dos 
processos de tomada de decisão da gestão dos recursos hídricos. Assim, entender de quais formas se dão os investimentos econômico na bacia hidrográfica do Rio das Velhas pode ser revelador de potencialidades de melhorias no planejamento e serviços vinculados ao tema.

\subsection{MÉTODOS}

Primeiramente, vale destacar que a área de pesquisa escolhida (Figura 10.2 (a)) apresenta uma localização estratégica em termos geográficos e de potencial de captação e utilização de recursos hídricos que poucas regiões no país podem contar. É uma grande área que está na parte central do estado mineiro e dentro de uma bacia hidrográfica maior (Rio São Francisco) que também é muito grande vasta e que percorre vários estados brasileiros. É uma bacia hidrográfica pertencente à Unidade de Planejamento e Gestão de Recursos Hídricos deste mesmo rio (UPGRH-SF5), que pode ser identificada pela Figura 10.2 (b).

Já a principal base de discussão sobre os recursos públicos existentes para a bacia hidrográfica do Rio das Velhas é fundamentalmente o plano de investimentos denominado como "Plano Plurianual de Aplicação" (PPA), que tem vinculação direta com o Plano Diretor de Recursos Hídricos (PDRH) da área (CAMARGOS, 2005), de acordo com as determinações legais Ele se constitui por um lado como um documento relacionado ao planejamento das políticas públicas em termos de investimentos e, por outro lado, como um norteador metodológico em relação à tipologia desses mesmos investimentos em um dado período acordado. Esse período pode variar de um caráter anual, como era feito inicialmente no comitê, ou mesmo de mais tempo, como de 3 anos, como passou a ocorrer em 2014.

Programa de Pós-graduação em Saneamento, Meio Ambiente e Recursos Hídricos da UFMG 
(a)

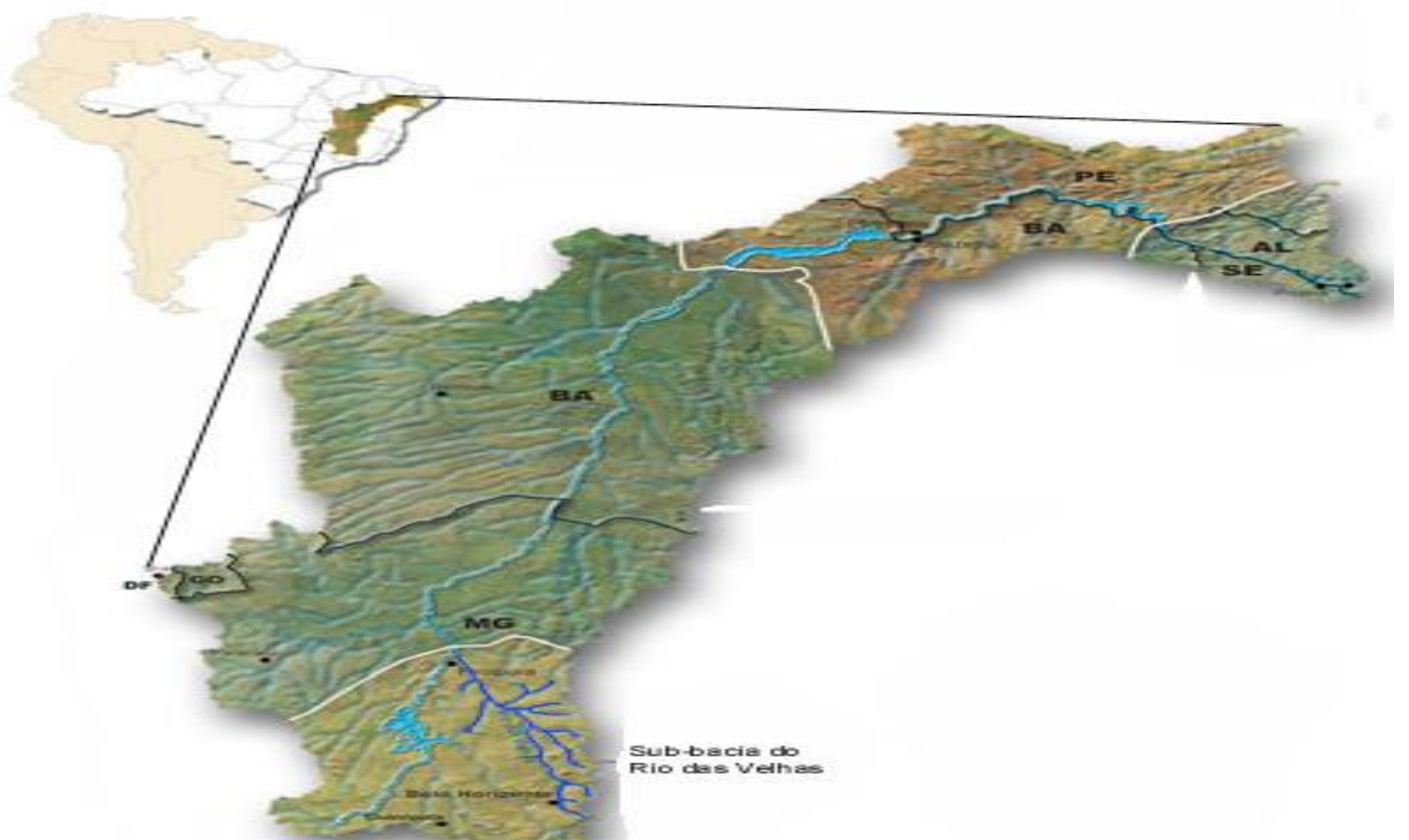

(b)

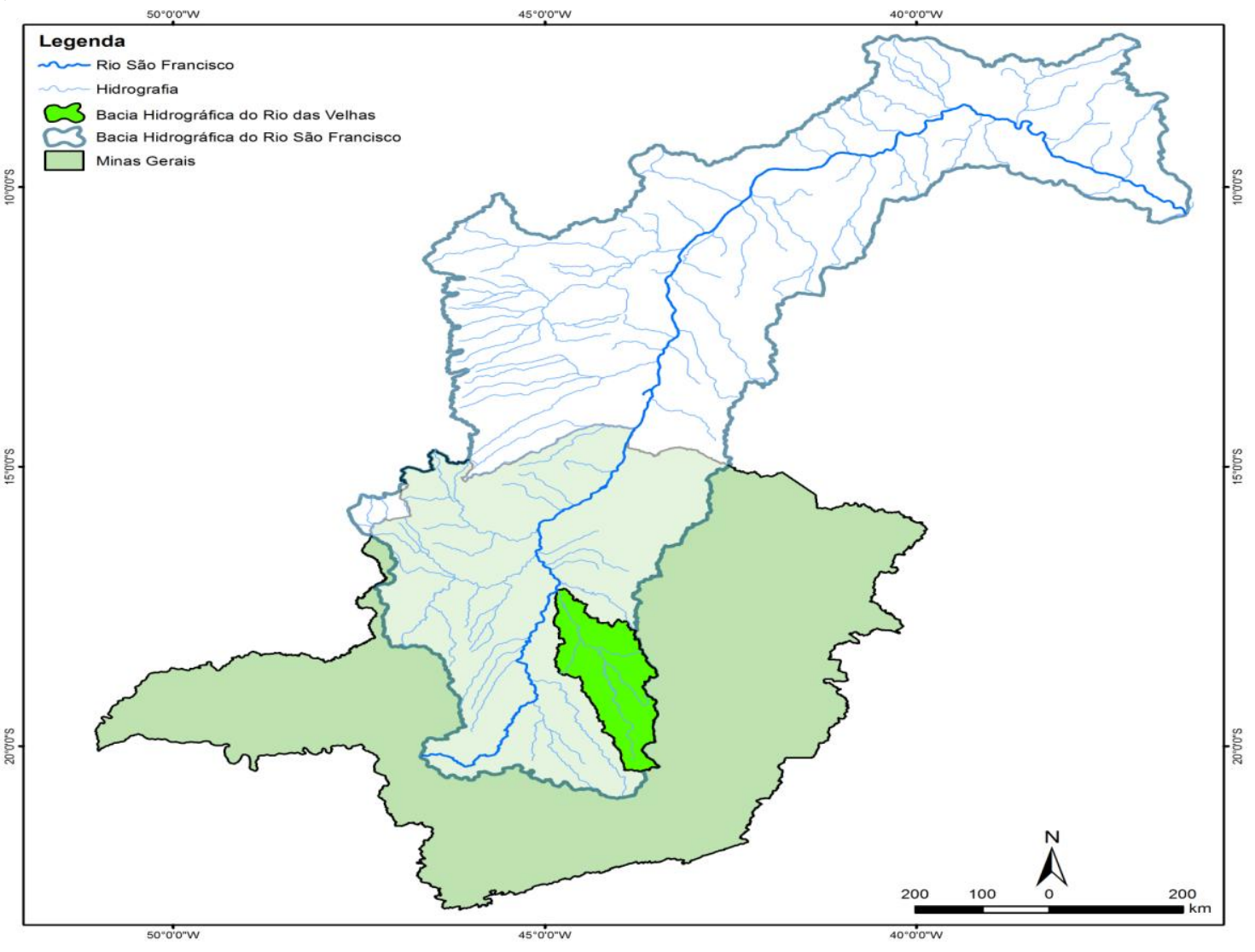

Figura 10.2: Localizações da bacia hidrográfica do Rio das Velhas: a) no país e na bacia hidrográfica do Rio São Francisco; b) na bacia hidrográfica do Rio São Francisco e em Minas Gerais

Fonte: CBH Velhas, 2013 
Essa mudança foi estabelecida de forma a propiciar à Agência de Água (denominada de " $A G B$ Peixe Vivo") maior capacidade de intervenção ao não pulverizar recursos para ações de curto prazo em projetos ou muito específicos ou que necessitam maior prazo para dar resultados (como recuperação de áreas degradas, por exemplo).

Neste sentido, a pesquisa procurou realizar a análise dos principais mecanismos legais e institucionais para a gestão dos recursos econômico-financeiros disponíveis (ou em via de captação, tais como fundos setoriais, parcerias e afins) para o CBHRV e de como estes potencialmente podem aprimorar a integração entre seus participantes via projetos denominados como "hidroambientais", ou eventos ou mesmo cursos de capacitação técnica. A isto é incorporado o conjunto de entrevistas com diversas lideranças relacionadas direta ou indiretamente ao CBHRV e também à AGBPV em relação aos tópicos sobre investimentos de recursos econômico-financeiros, e da gestão institucional da bacia como um todo.

No trabalho foi realizado o que é considerada como a "triangulação de métodos" de pesquisa, que significa a compatibilização de fundamentos, propósitos e resultados específicos que, em conjunto, podem fornecer uma estrutura explicativa mais consistente, a ver:

1) a "observação participante": advinda de trabalho de campo junto a todo o arcabouço jurídico e institucional relacionado aos organismos de bacia hidrográfica vinculados direta ou indiretamente ao CBHRV, desde o ano de 2005 a 2011. Nesse conjunto de organizações se incluem as Câmaras Técnicas, Agência de Águas, Conselhos, eventos científicos, culturais, técnicos e administrativos.

2) "entrevistas": foram realizadas 25 entrevistas individualizadas, semiestruturadas com as lideranças acadêmicas, institucionais, técnicas e sociais relacionadas com a temática dos recursos hídricos na área de abrangência da pesquisa, de forma direta ou indireta e foram selecionados a partir da formação por segmentos existente no CBHRV, se do setor privado/público/social. As entrevistas tiveram como característica a discussão sobre 8 diferentes temáticas relacionadas com os recursos hídricos, por meio de 18 perguntas que abarcaram 3 meios (físico/biótico/antrópico) e 4 dimensões (institucional; legal; integradora; econômica-financeira).

A proposta foi cobrir o maior número de representantes possível por segmento. Consequentemente a este método foi aplicada a etapa de "análise de conteúdo" sobre as 
entrevistas (CAMPOS, 2004), onde se buscou identificar as principais categorias de sentido presentes nos depoimentos das lideranças selecionadas; 3) "documentos": em que foram avaliados os diversos procedimentos e deliberações relativas aos investimentos econômicofinanceiros em termos de orçamento e gastos públicos.

Isto faz com que a pesquisa seja de base qualitativa, na busca de se identificar as potencialidades e limites a processos de gestão participativa nas tomadas de decisão envolvendo os recursos econômico-financeiros. Considera-se aqui o conceito de governança como processos institucionais que tentam coordenar social e institucionalmente ações coletivas distintas e quase sempre assimétricas em termos de poderes e recursos, e também como instrumento metodológico de análise (GREEN, 2007; TORTAJADA, 2001).

\subsection{RESULTADOS E DISCUSSÃO}

\subsubsection{A institucionalização da gestão de recursos econômico-financeiros no CBHRV}

Para o entendimento da aplicação de recursos econômicos na bacia hidrográfica referida é necessária a consideração da criação não só do procedimento de cobrança pelo uso de recursos hídricos, mas, primordialmente, da criação do próprio CBHRV, realizado em 1998, através do Decreto Estadual no 39.692. Ele foi idealizado como um espaço tanto de consulta como de normatização de procedimentos, que são deliberados conjuntamente pelos atores sociais envolvidos na gestão, em uma proposição diferente da composição tripartite clássica (sociedade civil, estado e mercado).

Isso porque, e tal como adverte SWYNGEDOUW (2005), o modelo de gestão triparte não pode ser considerado, ao menos de antemão, como tão democrático e participativo como se supõe (CASTRO, 2007). E isso se deve às e possíveis restrições de acesso, entendimento, infraestrutura interna/externa e voz (não sendo estas as únicas possíveis) que cada segmento encontra para poder se fazer representar em uma instância colegiada diversificada.

No caso específico deste comitê, a organização interna foi estruturada, desde o início do comitê, em termos quadripartites, sendo o grande diferencial a separação do poder público em dois tipos de representação: estadual e municipal, o que poucas vezes é realizado no país. Normalmente há apenas a separação entre Estado-Sociedade Civil-Setor Privado. Tal escolha foi um posicionamento, pelo CBHRV, de que as dinâmicas existentes entre os poderes locais 
e o regional são diferentes. Esse fato pode ser analisado sob duas perspectivas: de um lado, há uma preocupação de que os segmentos componentes no comitê possam ser estabelecidos em um nível mínimo (e pretenso) de igualdade de representação. Por outro, é um reconhecimento de que há uma assimetria de origem interna ao setor público, que não conseguiria realizar de forma igualitária políticas públicas de micro e macro intervenção.

Mais ainda, isso demonstra que os níveis de capacidade de articulação política para o desenvolvimento de ações ambientais encontram restrições e potencialidades diferentes e tal fato é refletido nas Deliberações Normativas (DN) existentes. Por exemplo, quase $50 \%$ dos recursos econômico-financeiros previstos para o período entre 2015-2017 está alocado para ações de implantação de projetos para recuperação, conservação e revitalização da bacia ao nível local e somente em torno de $22 \%$ dos recursos para ações de planejamento ao nível regional do território referido.

Cabe ressaltar que os 56 membros do comitê, estabelecidos por legislação, (28 titulares e 28 suplentes, representantes dos 4 segmentos componentes) tentam decidir de forma participativa os tipos de investimentos e programas a serem inseridos na bacia para cada período estabelecido via DN. Certamente que este processo foi sendo modificado da estrutura original, no sentido da criação de Câmaras Técnicas (CTs), procedimentos burocráticos tais como as próprias DNs ou pareceres do Conselho de Administração e toda uma gama de suporte ao gerenciamento hídrico que se almejava estruturar.

E mais uma vez cabe aqui ressaltar que o simples desenho institucional de representação quadripartite não pode ser garantia de que as assimetrias dos segmentos irão ser aumentadas, estabilizadas ou suprimidas e que processos de interação para governança sejam realizados (CUNHA; THEODORO, 2014).

Sendo governança considerada aqui como um processo para além de mecanismos tradicionais de gestão e institucionalização estatal (SWYNGEDOUW, 2005), na verdade até o contrário do intento de aumento da eficiência do modelo de comitê pode acontecer. Um exemplo seria que, com mais uma subdivisão, o processo de governança da bacia pode se tornar mais complexo e ter de assumir e lidar com mais riscos institucionais e sociais do que até então haveria (BECK et al, 1997; BECK, 2009; KOOIMAN, 2008). Inclusive, normalmente as políticas públicas geram resultados diferentes daqueles inicialmente intencionados (BOUDON, 1979).

Programa de Pós-graduação em Saneamento, Meio Ambiente e Recursos Hídricos da UFMG 
O surgimento de uma agência de bacia hidrográfica, diretamente vinculada às operações do comitê, foi uma questão legal e administrativa que demandou tempo para ser efetivada, sendo oficializada apenas em 15 de setembro de 2006 e o CBHRV começou suas atividades em 1998. Juridicamente, são entidades institucionais que detêm um caráter descentralizado e finalidades não lucrativas. Elas só podem existir a partir da declaração de interesse por parte dos comitês de bacia e, logo após, analisadas e confirmadas pelos conselhos regionais e nacional de recursos hídricos.

É, obviamente, uma medida legal também prevista na Lei Federal 9.433/97 para a efetivação da Política Nacional de Recursos Hídricos (PNRH) que visa inserir as agências, assim como os comitês, dentro do Sistema Nacional de Gerenciamento de Recursos Hídricos (SINGREH), como medida de ação integrada de gestão. Já a prática tem demonstrado que as temporalidades de ação de CBHs e Agências nem sempre são os mesmos e é preciso processos de entendimentos contínuos para funcionar tal pretensa parceria (SEPÚLVEDA et al., 2011; THEODORO; MARQUES, 2014).

No caso específico da agência do Rio das Velhas, a escolhida foi a "Associação Executiva de Apoio à Gestão de Bacias Hidrográficas Peixe Vivo” - AGBPV, que se caracteriza por ser uma associação civil, pessoa jurídica de direito privado, formada tanto por organizações da sociedade civil quanto por usuários de recurso hídricos (IGAM, 2014(a)). Possui um Conselho Fiscal, um Conselho de Administração e uma Diretoria Executiva, sendo que esta suporta tecnicamente as decisões da Assembleia Geral, órgão soberano da agência. Enfim, a AGBPV é uma entidade delegatária de duração indeterminada e que se vincula diretamente às determinações legais de âmbito estadual e federal, além das determinações do próprio comitê.

Nesse ponto cabe a reflexão de que a agência é um braço executivo do comitê vinculante, sendo por este determinado em suas ações, ao menos em termos teóricos e legais, e não o contrário (THEODORO; MARQUES, 2014; JOHNSSON e LOPES, 2003). Cabe à agência a implantação das políticas de recursos hídricos de seu comitê que é, diretamente, o organismo de bacia a ser considerado no sistema de gestão de recursos hídricos como um todo. Atualmente, a AGBPV está responsável pelo gerenciamento executivo dos comitês do Rio das Velhas e do Rio Pará, regionais, e do Comitê da Bacia Hidrográfica do Rio São Francisco (CBHSF), que possui caráter nacional. 
Para dar ordenamento ao funcionamento da agência citada, foram instituídos dois contratos de vigência entre a AGBPV e o Instituto Mineiro de Gestão das Águas (IGAM), sendo o primeiro de três anos (assinado em 2010) e o segundo de quatro anos (assinado em 2012). Isto significa em termos práticos que a agência tem de prestar contas não só ao CBHRV como também à instituição de governo com a qual celebrou os acordos. E isso se dá através do detalhamento de suas ações durante o ano, o que inclui valores absolutos e percentuais de desembolso anual e acumulados.

O que significa que cada valor aplicado deve ser explicado também em termos de percentual de investimento por área ou temática. Também são de sua responsabilidade a implementação do Plano Diretor de Recursos Hídricos (PDRH); a complementação e atualização dos cadastros dos usuários e a avaliação pelos membros e usuários do comitê sobre suas ações. Essa série de medidas de acompanhamento e gestão necessária porque é a AGBPV quem faz a aplicação dos recursos econômico-financeiros na bacia do Rio das Velhas, a partir do advento da cobrança pelo uso múltiplo de recursos hídricos.

No entanto, um fato subjacente a essas ações é que tal exercício (acompanhamento/gerenciamento) se relaciona com uma perspectiva de processos de governança em que todos os segmentos seriam participativos, consultivos e/ou deliberativos, além de compreensivos criticamente dos instrumentos envolvidos (outorga, cobrança, enquadramento, sistema de informações, plano diretor). E, de acordo com as entrevistas e pesquisas de campo realizadas e analisadas, esse ainda não é o cenário de dinâmica do CBHRV, que ainda tem lacunas em suas ações participativas, descentralizadas e integradas, que são algumas das características principais demandadas para que a governança se realize.

Principalmente também quando há um modelo de tomada de decisão por comitês e conselhos (MELLO e REZENDE, 2014; THEODORO; MATOS, 2015), como também pela existência de área metropolitana na questão (PORTO et al., 2006; TORTAJADA e CASTELÁN, 2003; MMA, 2011), como é o caso do comitê estudado. A região metropolitana de Belo Horizonte é a área de maior adensamento populacional e poluidor dentro da bacia hidrográfica do Rio das Velhas e também do próprio estado de Minas Gerais (CAMARGOS, 2005; CHB VELHAS, 2012).

Dentro dessa estrutura, cabe ressaltar, a ação estatal de definição de planos, programas e projetos é muito presente e tende a reproduzir procedimentos de comando e controle 
tradicionais (com destaque para projetos de infraestrutura e menos para capacitação interna, por exemplo) com pouca ação de análise institucional conjunta na direção de mudanças ou aprimoramentos de procedimentos (BECK et al, 1997; BECK, 2009). Esses procedimentos, inclusive, restringem ações para além da concepção estatal, com possível menor autonomia dos atores sociais participantes (SWYNGEDOUW, 2005)

Apenas em 2009 o CBHRV instituiu a cobrança pelo uso da água, ainda que já constasse das legislações recorrentes, principalmente a Lei Federal $n^{\circ} 9.433$ de 1997 e a Lei Estadual $n^{\circ}$ 13.999 (regulamentada apenas em 2005, pelo Decreto $n^{\circ}$ 44.046). Isso se deu justamente pela necessidade de se afinar o arcabouço jurídico ao sistema de gestão hídrica que existia, inclusive com melhores definições do papel dos organismos de bacia participantes.

Mas, deve-se salientar, existem atualmente 18 normativas legais relativas à cobrança pelo uso de recursos hídricos em Minas Gerais que devem ser consideradas para toda decisão relativa ao tema (IGAM, 2014(b)). Isto poderia ser considerado um indicativo da importância crescente do assunto na agenda pública, política e institucional da gestão hídrica, ao mesmo tempo em que indica a complexidade existente no tema

O gerenciamento de recursos hídricos atualmente tem, cada vez mais, tentado basear decisões em termos socioambientais e técnicos conjugados, em uma perspectiva de governança, ou seja, se fazer interagir e gerar possibilidades de interação (KOOIMAN, 2008) entre diferentes atores sociais e institucionais (GREEN, 2007). O maior exemplo dessa tendência se encontra na atualização do Plano Diretor de Recursos Hídricos da bacia hidrográfica do Rio das Velhas, finalizado em 2015 e onde a questão da consolidação de processos de gestão participativa é salientada.

A governança aqui compreendida implica na relação entre os atores institucionais envolvidos e, partir desse contexto, se desenvolvem as consultas e deliberações em termos da criação/inclusão/consolidação de processos participativos, integrados e, essencialmente, mais democráticos. Nessa condição, a formalização de procedimentos administrativos relativos aos valores econômicos oriundos da cobrança pelo uso múltiplo dos corpos de água refletem também um crescimento regional e nacional da cobrança - como na Figura 10.3 é demonstrada, há uma evolução na captação dos recursos hídricos ao nível da instância da 
União:

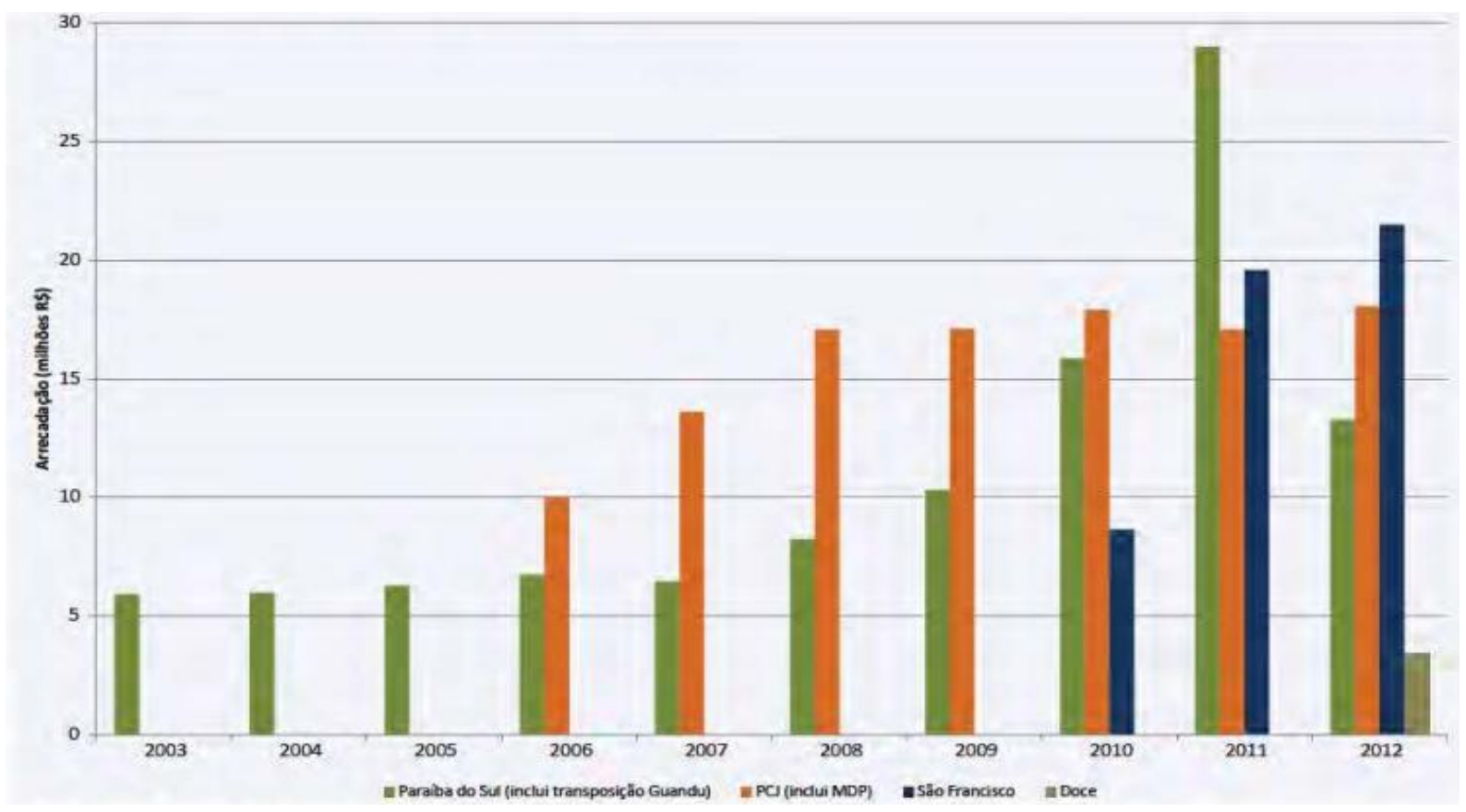

Figura 10.3: Evolução da arrecadação com a cobrança pelo uso de recursos hídricos de domínio da União

Fonte: ANA (2013)

Também vale acrescentar que o CBHRV foi o primeiro organismo de bacia no Estado a assumir a cobrança pelo uso da água que, em termos de proposta, significaria a incorporação do preceito da água como bem natural dotado de valor econômico (Lei Federal 9.433/97). A cobrança visa, ao menos pretensamente, ao reconhecimento da água como um bem ecológico, social e econômico (MOURA e ARAÚJO, 2014), dando ao usuário uma indicação de seu real valor, além de estimular a racionalização de seu uso (IGAM, 2014(f); IGAM, 2015; IGAM, 2016).

A implementação da cobrança foi precedida por um processo longo de estudos e discussões com os diversos segmentos da bacia, que teve início durante a fase de elaboração do Plano Diretor de Recursos Hídricos da bacia, aprovado em dezembro de 2004. A Deliberação CBH Rio das Velhas $\mathrm{n}^{\circ}$ 03, de 20 de março de 2009, estabelece critérios e normas e define mecanismos básicos da Cobrança pelo Uso de Recursos Hídricos na Bacia Hidrográfica do Rio das Velhas. Ela não é um imposto e sim um preço público para controle e incentivo ao uso racional dos recursos hídricos, sendo que só pagam os usuários que possuem captação ou derivação de: extrações de águas subterrâneas; lançamentos de efluentes em corpos d'água; 
extrações de águas subterrâneas, considerados como significantes pelo órgão competente (IGAM, 2016).

Sua metodologia de cálculo é feita por cada comitê respectivo da bacia hidrográfica em análise, e é revista anualmente, para cada usuário, com a aprovação também do Conselho Estadual de Recursos Hídricos (CERH). Após a definição dos valores, são emitidos os boletos de pagamento denominados de DAE (Documentos de Arrecadação Estadual), pela Secretaria de Estado da Fazenda (SEF) e enviados aos usuários cadastrados.

Tal como é descrito em IGAM (2016), até o início do ano de 2016 existem 4 agências de bacias em atuação no estado de Minas Gerais. Elas atuam nas 6 atuais (2016) bacias hidrográficas mineiras (e seus afluentes) que já implementaram o instrumento da cobrança pelo uso dos recursos hídricos, totalizando mais de 235 milhões de reais em valores de 2016.

Como se pode identificar no mesmo, em termos comparativos, a capacidade de captação de recursos econômicos e financeiros para as diversas bacias é bastante diferente (não só porquê cada bacia tem perfil socioambiental distinto, como também institucional) tanto em termos absolutos quanto percentuais, o que pode ser um indicador das insuficiências da gestão em consolidar um sistema de arrecadação de fundos.

Dada sua importância no cenário dos recursos hídricos em Minas Gerais, o CBHRV é o que lida com o maior montante de recursos, mas não é o que consegue em maior percentual a equiparação entre o que é cobrado e o que é captado efetivamente. Há, inclusive (Tabela 10.1), bacias que conseguem arrecadar até mais do que o previsto inicialmente devido, possivelmente, às suas configurações de usuários cadastrados, atuação da agência e do comitê. O que também indica uma necessidade de adequação das formas de identificação dos possíveis pagadores, como também de análises mais individualizadas para se possibilitar entender tais diferenças. 
Tabela 10.1: Total arrecadado até 2014 pela cobrança pelo uso de recursos hídricos nas bacias implantadas em Minas Gerais.

\begin{tabular}{lcrrrr}
\hline \multicolumn{1}{c}{ Bacia } & Período & $\begin{array}{l}\text { Cobrança } \\
\text { Prevista }\end{array}$ & Arrecadado & $\begin{array}{c}\text { Diferença } \\
\text { Absoluta }\end{array}$ & $\begin{array}{r}\text { Diferença } \\
\text { Percentua } \\
\text { l }\end{array}$ \\
\hline Velhas & $2010-2014$ & $48.869 .744,28$ & $41.058 .031,35$ & $7.811 .712,93$ & $15,98 \%$ \\
\hline Araguari & $2010-2014$ & $26.237 .568,60$ & $25.219 .715,50$ & $1.017 .853,10$ & $3,88 \%$ \\
\hline PJ & $2010-2014$ & $409.844,85$ & $423.309,24$ & $(+) 13.464,69$ & $(+) 3,29 \%$ \\
& & & & & $*$ \\
\hline Piranga & $2010-2014$ & $7.526 .405,95$ & $7.465 .011,71$ & $61.394,24$ & $0,82 \%$ \\
\hline Piracicaba & $2010-2014$ & $19.983 .549,53$ & $19.389 .512,31$ & $594.037,22$ & $2,97 \%$ \\
\hline $\begin{array}{l}\text { Santo } \\
\text { Antônio }\end{array}$ & $2010-2014$ & $4.371 .435,96$ & $4.281 .497,51$ & $89.938,45$ & $2,06 \%$ \\
\hline Suaçui & $2010-2014$ & $1.611 .685,34$ & $1.550 .761,32$ & $60.924,02$ & 3,78 \\
\hline Caratinga & $2012-2014$ & $1.743 .919,03$ & $1.740 .145,44$ & $3.773,59$ & $0,22 \%$ \\
\hline $\begin{array}{l}\text { Manhuaç } \\
\text { u } 2012-2014\end{array}$ & $1.769 .393,23$ & $1.891 .253,00$ & $(+) 121.859,77$ & $(+) 6,89 \% *$ \\
\hline Total & & $112.523 .556,76$ & $103.019 .237,38$ & $9.504 .319,38$ & $8,45 \%$ \\
\hline
\end{tabular}

*Percentuais arrecadados acima dos valores cobrados estipulados.

Fonte: IGAM (2011); IGAM (2013); IGAM (2014(e)).

Cabe salientar que, de acordo com a determinação legal federal ( $n^{\circ}$ 9.433/97) e, principalmente, estadual (13.199/99), pertinente, $100 \%$ de todos os recursos que forem arrecadados pelo sistema de cobrança pelo uso múltiplo hídrico deverão ser obrigatoriamente investidos na bacia hidrográfica de origem e gerenciados por sua agência, via orientação do comitê. Mais ainda, a composição percentual de aplicação deverá ser de tal forma: 1) 92,5\% em estudos, projetos, obras e programas, em concordância com o PDRH da bacia hidrográfica referida; 2) 7,5\% no pagamento de despesas com o custeio da agência de bacia e/ou entidade equiparada - essa distribuição está amparada na Lei Estadual $n^{\circ} 20.311 / 2012$ e no Decreto Estadual $n^{\circ} 45.230 / 2009$. Essa distribuição é fiscalizada tanto pelo comitê, via sua Câmara Técnica de Planejamento, Projetos e Controle (CTPC), como também pela própria AGB Peixe Vivo, que faz os demonstrativos de tais possíveis aplicações.

Porém, de acordo com as entrevistas realizadas e, mais recentemente até com a confirmação pelo próprio órgão gestor (IGAM, 2016(b)), nem sempre esses percentuais foram respeitados, o que seria devido tanto pela impossibilidade de pagamento de taxas relativas a taxas bancárias, como também falta de conformidade no uso dos recursos por desconhecimento ou interpretação errônea da legislação. Porém, em março de 2016 foi anunciada a aplicação tal como prevista em lei para reestruturação dos organismos de bacia existentes. É uma nova 
oportunidade para o desenvolvimento institucional da bacia, porém sua veracidade em termos de aplicação somente poderá ser avaliada ao final do atual plano de exercício fiscal da agência, a ser discutido adiante.

De acordo especificamente com as entrevistas realizadas com as lideranças dos órgãos de gestão ambiental, tal medida poderia ser considerada um avanço institucional, ao colocar foco na estruturação da bacia na qual os recursos são provisionados. Já de acordo com as lideranças sociais entrevistadas, esse movimento poderia, em tese, fortalecer os arranjos locais e facilitar o desenvolvimento regional, inclusive com a inclusão de novos usuários que, ao verificarem possibilidades de recursos econômico-financeiros para suas regiões, passariam a atuar mais. Na prática há um crescente investimento dos recursos cada vez mais via a implantação de processos hidroambientais (recuperação de áreas degradas, contratação da realização de Planos Municipais de Saneamento (PMS) e capacitação dos membros do comitê).

No entanto, tal caminho ainda está a ser consolidado e demanda mais ações institucionais para ocorrer, como, por exemplo, identificar quais as lacunas entre valor cobrado dos usuários cadastrados e o valor efetivamente arrecadado, sob o risco de não se justificar novos investimentos na bacia futuramente; vê-se tal situação no Tabela 10.2.

Tabela 10.2: Demonstrativo de valores cobrados e arrecadados na bacia hidrográfica do Rio das Velhas entre 2010 e $2014(\mathrm{R} \$)$

\begin{tabular}{lcccccc}
\hline \multicolumn{1}{c}{ ANO } & $\mathbf{2 0 1 0}$ & $\mathbf{2 0 1 1}$ & $\mathbf{2 0 1 2}$ & $\mathbf{2 0 1 3}$ & $\mathbf{2 0 1 4}$ & TOTAL \\
\hline $\begin{array}{l}\text { Cobrança } \\
\text { Prevista }\end{array}$ & $7.913 .942,01$ & $9.094 .596,88$ & $8.803 .252,83$ & $12.276 .536,64$ & $10.781 .415,92$ & $\mathbf{4 8 . 8 6 9 . 7 4 4 , 2 8}$ \\
\hline $\begin{array}{l}\text { Arrecadado } \\
7.234 .303,86\end{array}$ & $7.891 .625,64$ & $7.233 .001,89$ & $9.322 .671,12$ & $9.376 .428,84$ & $\mathbf{4 1 . 0 5 8 . 0 3 1 , 3 5}$ \\
\hline $\begin{array}{l}\text { Diferença } \\
\text { Absoluta }\end{array}$ & $679.638,15$ & $1.202 .971,24$ & $1.570 .250,94$ & $2.953 .865,52$ & $1.404 .987,08$ & $\mathbf{7 . 8 1 1 . 7 1 2 , 9 3}$ \\
\hline $\begin{array}{l}\text { Diferença } \\
\text { Percentual }\end{array}$ & $8,59 \%$ & $13,23 \%$ & $17,84 \%$ & $24,06 \%$ & $13,03 \%$ & $\mathbf{1 5 , 9 8 \%}$ \\
\hline Fo
\end{tabular}

Fonte: Adaptado de, IGAM (2011); IGAM, 2014(e)

Os quase 8 milhões de reais de diferença entre os valores cobrados e os valores arrecadados (ou seja, 15,98\% do valor montante total ilustram como há uma defasagem entre os dois, no sentido de que o que deveria ser realmente o procedimento de captação de recursos para aplicação na bacia não ocorre adequadamente, visto que desde o início da cobrança, os dois montantes nunca foram correspondentes, pelos motivos descritos anteriormente de falta de

Programa de Pós-graduação em Saneamento, Meio Ambiente e Recursos Hídricos da UFMG 
alinhamento institucional na aplicação da legislação. Entre os anos de 2010 a 2014, por exemplo, os percentuais variaram de $8,59 \%$ em seu início e depois foram se expandindo crescentemente de 13,23\% (2011), 17,84\% (2012) a 24,06\% em seu ápice (2013), com retração para 13,03\%. - o que gerou uma diferença percentual média de 15,98\% nesse período. Em uma análise comparativa, essa flutuação de valores seria reflexo das relações institucionais presentes na bacia entre seus organismos de gestão, com o desalinhamento entre os proponentes dos contratos de gestão e dos conselheiros dos comitês participantes (IGAM, 2016(b)).

\subsubsection{O Plano de Aplicação}

De forma a se entender melhor como se dá o processo de definição de investimentos, além das atas de discussão, cabe recorrer ao principal elemento documental existente para o planejamento de ações na bacia, o "Plano Plurianual de Aplicação" (PPA). Ele é um instrumento de gestão na bacia, uma vez que é previsto constitucionalmente e também através de Deliberação Normativa (DN), sendo a mais atual a de $n^{\circ} 10 / 2014$, que se refere ao exercício dos anos de 2015 a 2017 e que visa primordialmente a dar maior celeridade aos recursos captados pela cobrança via desembolso.

Concomitantemente, ele permite um acompanhamento coletivo sobre quais as áreas prioritárias de ação e dá diretrizes econômicas (bens e serviços a serem oferecidos, informação monetária) e financeiras (gestão dos ativos e dos investimentos), que favorecem avaliações sociais e institucionais. Essas referidas avaliações são demandatórias à AGBPV que deve cumprir diversos índices de metas: 1) Disponibilização de informações; 2) Planejamento e gestão; 3) Cobrança pelo uso dos recursos hídricos; 4) Operacionalização da cobrança; 5) Reconhecimento Social. Essas metas são avaliadas posteriormente por seus conselhos fiscal e de administração, além dos comitês aos quais a agência está vinculada.

No caso do CBHRV e sua respectiva gestão, verifica-se um aumento gradativo da diversificação da provisão de recursos) devido justamente às deliberações do comitê, que reconhecem cada vez mais as complexidades da gestão), que contam com mais tópicos do que sua primeira versão. Enquanto em 2010-2011, o denominado "Plano de Aplicação" (PA), de caráter anual, descrevia apenas o valor total de repasse dos investimentos do Contrato de Gestão com o IGAM, já em 2012 há uma categorização muito maior. Nela constam tanto o saldo financeiro existente como também a projeção de receita financeira; o valor de repasse 
da cobrança e do valor previsto de captação relativa à cobrança para o ano consequente à sua implantação.

Já no PPA, para os anos de 2013 e 2014, assim como para 2015-2017, as atividades foram estabelecidas a partir de três grandes grupos de ação: 1) Programas e Ações de Gestão; 2) Programas e Ações de Planejamento; 3) Programas e Ações Estruturais de Revitalização. Cada um desses grupos teve, portanto, subdivisões para facilitar sua implementação (componente; subcomponente; ação programada; atividade). Esse posicionamento metodológico também poderia ser lido como uma tentativa de se tentar qualificar melhor os investimentos a serem realizados, uma vez que são mais específicos do que os Planos de Aplicação anteriores, principalmente o primeiro, de 2010. Na prática, esse modo de planificação tem demonstrado gradativamente uma melhor compreensão de como são realizadas as aplicações por parte das populações das sub-bacias, assim como dos membros do comitê.

Verifica-se também que, nos dois primeiros anos de sua realização, o Plano de Aplicação foi de caráter anual em sua aplicação, com planejamento de acordo com cada idem ou subitem, mas sempre a findar em dezembro de cada ano de exercício. Posteriormente foi modificado com a Deliberação Normativa do CBHRV, $n^{\circ}$ 12, de dezembro de 2011, tendo como base a Deliberação Normativa do comitê, que aprova o Contrato de Gestão com o IGAM.

Esse modelo de gestão via PPA tem sido cada vez mais utilizado e conta com inserção, inclusive, no Ministério do Meio Ambiente. Um possível problema que surge é os vários órgãos vinculados com a gestão ambiental (secretarias municipais e estaduais, prefeituras etc) que utilizam tal modelo de PPA possuem cronologias, agendas e necessidades diferentes em termos temporais, de recursos humanos e materiais. Além também de, eventualmente, corroborarem as mesmas ações, o que pode diminuir a eficiência da gestão pública.

A partir das entrevistas com as lideranças relacionadas direta ou indiretamente com o processo de gestão de recursos hídricos do Rio das Velhas e de sua bacia, assim como a população em geral, ficou evidenciado que de forma geral há uma visão técnica e burocrática sobre a aplicação dos recursos econômico-financeiros, mas que tal não é errado pois devem seguir as linhas de procedimentos ditados pela Lei Federal no 8.666/93. Ou seja, o PPA é um instrumento de planejamento a partir das priorizações do CBHRV, e que deve seguir os 
trâmites legais para a implantação das suas ações, a depender do produto/serviço a ser entregue.

Como exemplos, cabe citar que para a realização de um plano municipal de saneamento básico, o prazo é de 10-12 meses; para os atuais trabalhos de atualização do PDRH do comitê, o prazo é de dezoito meses; para execução de projetos ambientais/saneamento a definição depende do escopo/tempo/custo e para diagnósticos, estudos e projetos o prazo estabelecido fica entre 4-8 meses. Ou seja, cada categoria de recurso tem um tempo próprio para sua implementação, o que não é facilmente entendido pelos membros do CBHRV, de acordo com as entrevistas realizadas.

Exemplos poderiam ser sobre a implantação dos projetos hidroambientais para recuperação de nascentes, como também os processos de seleção para realização de Planos Municipais de Saneamento. Todos esses processos, que são originários das demandas dos membros do comitê, são avaliados, primeiramente, pela Câmara Técnica de Planejamento, Projetos e Controle (CTPC) e, posteriormente, pela AGB Peixe Vivo, que emite um parecer a ser apreciado nas plenárias gerais que ocorrem no decorrer do ano no CBHRV. Somente após sua aprovação em plenária, após explicações e discussões que se fizerem necessárias por demanda dos membros, CTPC ou agência, é se faz o encaminhamento para implantação da proposta referida. Cada proposta implementada será depois verificada também junto ao IGAM (IGAM (2014(d)). Internamente, o procedimento de encaminhamento de demandas de projetos ao comitê segue a Figura 10.4:
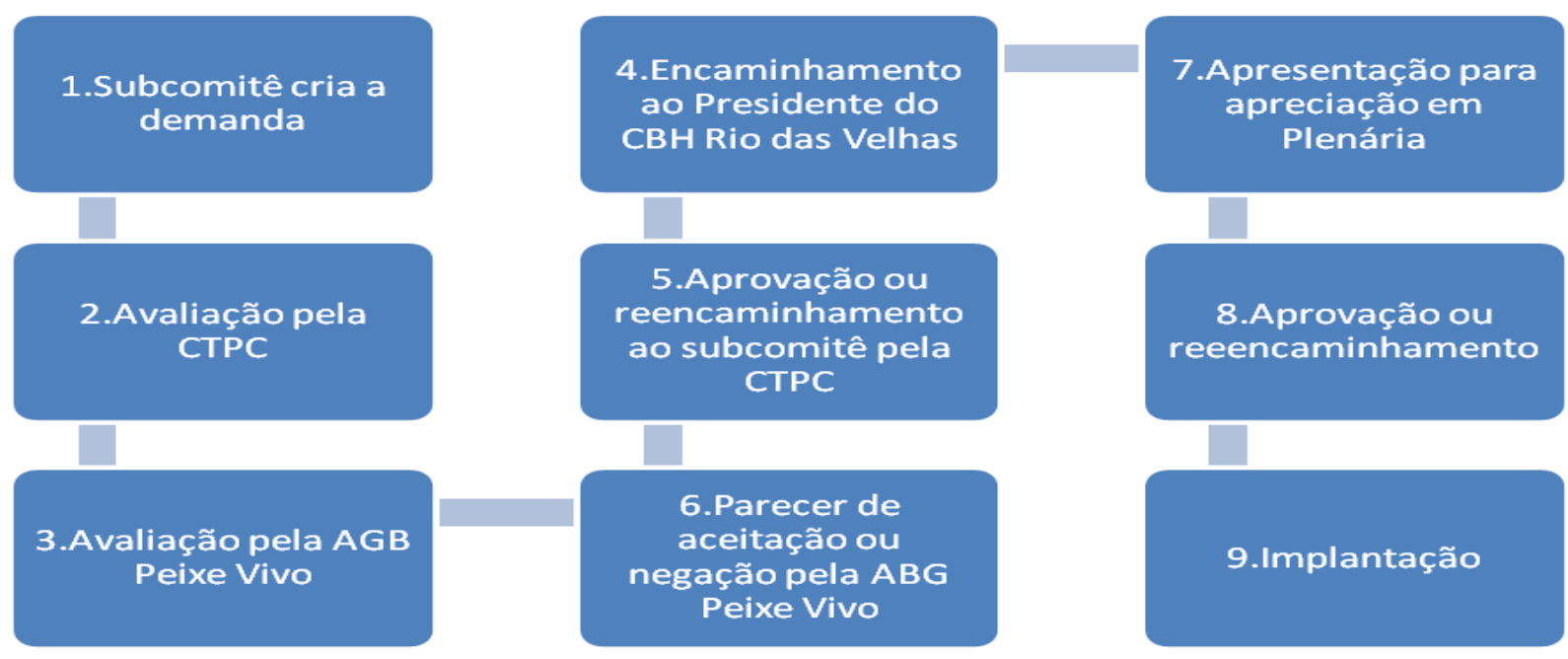

Figura 10.4: Procedimento para encaminhamento de demandas de projetos no CBHRV 
Por outro lado, esses procedimentos não foram identificados como plenamente compreendidos tanto na pesquisa de campo como também nas entrevistas que citaram todo esse processo como muito cartorial e burocrático. Haveria, aparentemente, um descompasso temporal entre as demandas dos vários setores, principalmente da sociedade civil, e a capacidade de resposta da agência de bacia. Ao mesmo tempo, a AGBPV tem sido bem avaliada nos relatórios publicados pelo IGAM, inclusive pelos membros do CBHRV.

Esses relatórios foram realizados a partir de questionários aplicados em reuniões plenárias e constam das atividades demandatórias à agência para a aferição de seu desempenho anual junto aos membros do comitê - e que foram confirmadas tanto nas entrevistas com lideranças, como também na pesquisa de campo, onde o primeiro autor deste artigo pôde ver a aplicação do referido questionário. Ao mesmo tempo, há demandas pelos membros do comitê por um maior esclarecimento sobre como os recursos da cobrança são utilizados.

O contraste da situação poderia ser considerado pelo fato de a agência não ter conseguido ainda manter um padrão de gastos igual ao seu montante anual (como demonstrado anteriormente), porém tem mantido um desempenho acima do estabelecido nos seus índices do Contrato de Gestão junto ao IGAM (IGAM, 2013-c).

De acordo com entrevista realizada junto à Diretoria Técnica da AGBPV, a questão de muitas vezes os desembolsos não serem efetuados ou os processos durarem mais do que o previsto ou atrasarem é reflexo, principalmente a partir de 2012, em termos de adequações aos percentuais para custeio $(7,5 \%)$ e investimentos na bacia $(92,5 \%)$, demandadas pelo IGAM. A questão do custeio operacional, por exemplo, colocou a agência em conflito com o CBHRV pela contenção de gastos que foram efetuados.

De acordo com a Diretoria Técnica da AGBPV, outro fator que contribuiu para algumas decisões se deu pelos atrasos do repasse de verbas do IGAM à agência, uma vez que esta não pode receber os recursos diretamente do erário federal, mas sim via órgão gestão da área, tanto por ser pessoa jurídica de direito privado como por ser o órgão executivo dos comitês que, por legislação federal e estadual, não possuem personalidade jurídica própria. Houve, inclusive, corte de pessoal (em torno de 15 profissionais), em destaque para o grupo responsável pela mobilização social na bacia e isso gerou uma série de conflitos por conta das interpretações diferentes entre os órgãos gestores e o comitê e que foram resolvidos apenas 
após vários meses de conversações entre os órgãos e os organismos de bacia. Tal descompasso pode ser acompanhado a partir da Tabela 10.3.

Tabela 10.3: Totais de arrecadação e repasses no CBHRV

\begin{tabular}{lrrr}
\hline EXERCÍCIO & COBRADO & ARRECADADO & \multicolumn{1}{c}{$\begin{array}{c}\text { REPASSADO } \\
\text { (até outubro de cada ano) }\end{array}$} \\
\hline 2010 & $7.913 .942,01$ & $7.234 .303,86$ & $7.071 .446,58$ \\
\hline 2011 & $9.094 .596,88$ & $7.891625,64$ & $7.942 .209,92$ \\
\hline 2012 & $8.803 .252,83$ & $7.233 .001,89$ & $6.745 .685,41$ \\
\hline 2013 & $12.276 .536,64$ & $9.322 .671,12$ & $8.489 .748,54$ \\
\hline 2014 & $10.781 .415,92$ & $9.376 .428,84$ & $7.284 .696,13$ \\
\hline TOTAL & $\mathbf{4 8 . 8 6 9 . 7 4 4 , 2 8}$ & $\mathbf{4 1 . 0 5 8 . 0 3 1 , 3 5}$ & $\mathbf{3 0 . 2 4 9 . 0 9 0 , 4 5}$ \\
\hline
\end{tabular}

Fonte: IGAM (2014(e)); IGAM (2014(f)).

Um fato também a ser considerado é que os investimentos econômico-financeiros a serem feitos na bacia hidrográfica do Rio das Velhas devem ser considerados somente a partir de "estimativas" de arrecadação pela cobrança por uso dos recursos hídricos e não por um orçamento fixo, ano a ano, mesmo que o ano anterior sirva como parâmetro para discussão. Ou seja, o atual PPA tem desembolsos prováveis de atuação de acordo com cada ano de exercício, que leva em consideração o "resultado da valorização das atividades a serem executadas" (CBHRV, 2012).

Tal situação evidencia que se a gestão estiver baseada simplesmente em termos de sua capacidade projetada de recursos via cobrança poderá haver uma série de descompassos entre o que foi planejado e o que foi realmente captado junto aos usuários de água para fins de implantação de políticas públicas diversas. Na mesma direção, e tal como foi levantado nas entrevistas e no campo, há um disparate entre a quantidade de recursos que seriam necessários para o efetivo desenvolvimento da bacia hidrográfica do Rio das Velhas (na ordem de centena de milhões de reais por ano) e aquela que é verdadeiramente alocada para tal (da ordem de dezenas de milhões de reais por ano).

Objetivamente, a relação seria entre a demanda estipulada, em torno de mais de 800 milhões de reais por parte do Projeto Manuelzão (um dos principais atores sociais relacionado com a gestão do comitê, que alcançariam mais de um bilhão de reais em valores de 2014) para a recuperação da bacia hidrográfica em questão, e os valores estimados de arrecadação anual, de R \$ 9.423.109,63 em 2013, por exemplo. Mais ainda, ao se considerar o PDRH em si, em 
sua atualização de 2004, os investimentos estimados para a recuperação ambiental da bacia perfazem recursos em torno de R $\$ 5$ bilhões de reais, em valores de 2012 (IGAM, 2014(a)).

Porém, é válido ressaltar que existem fontes de recursos públicos para além das previstas pela cobrança do uso de recursos hídricos que se destinam a ações de melhorias para bacias hidrográficas e seus municípios constituintes, seja no orçamento da União, Estados, municípios ou autarquias. Existem também investimentos setoriais (ou seja, recursos de áreas indiretas e correlacionadas) que, junto às outras possíveis fontes citadas, devem ser mais bem analisadas (MMA, 2011) com fins de planejamentos vindouros. O que falta, porém, e de acordo com a análise de conteúdo realizada nas entrevistas com as lideranças do meio, é uma maior interação institucional (KOOIMAN, 2008) e um maior conhecimento dos trâmites funcionais (IGAM, 2015) para que essa captação ocorra.

Isso inclusive pelos técnicos participantes das instituições responsáveis pelas políticas públicas de recursos hídricos, como também os próprios membros do CBHRV, o fato é que existiria aí uma lacuna importante a ser considerada para futuras políticas públicas de intervenção na bacia e que se coloca na impossibilidade de se contar categoricamente com todos os recursos projetados, seja pela inadimplência, atrasos ou desligamentos dos usuários de água vinculados ao sistema de cobrança.

Da mesma forma, há possibilidades também de que as pretensas captações de recursos adicionais (fundos nacionais ou internacionais de investimentos, por exemplo) para serem aplicados na bacia do Rio das Velhas não aconteça, sejam pelas insuficiências técnicas e estruturais de alguns municípios (ABERS, 2010), sejam pelos trâmites institucionais e burocráticos inerentes à possíveis captações, assim como por mudanças dos cenários políticos e institucionais macros.

Um exemplo claro dessa situação de desestrutura por parte dos municípios brasileiros e mineiros é que, de acordo com a Confederação Nacional de Municípios (CNM), das 5.570 cidades do país, 5.368 (96,4\%) encerraram o ano de 2014 com irregularidades no Cadastro Único de Convênios (CAUC), que é um sistema de informações sobre transferências voluntárias de recursos da União. Isso impede, ao menos parcialmente e na medida em que são feitos ajustes às irregularidades verificadas, a captação de recursos de ordem federal por parte dos municípios afetados.

Programa de Pós-graduação em Saneamento, Meio Ambiente e Recursos Hídricos da UFMG 
No caso de Minas Gerais, o percentual foi de 97,5\% dos municípios (ou seja, 832 de 853) em condição não favorável a participar de repasses de recursos nacionais (tais como os da Agência Nacional de Águas, Ministério do Meio Ambiente etc) (CNM, 2014). O que demanda um cenário de articulação de boa governança para se minimizar o problema de falta de estrutura institucional para captação de recursos do erário público, uma vez que às determinações legais a administrativas devem ser acopladas articulações políticas e institucionais. Certamente que tais processos não são lineares e contingências na gestão podem ocorrer.

Dentro dessa realidade díspar entre a quantidade de recursos necessários para sanar as demandas existentes na bacia hidrográfica do Rio das Velhas e a estrutura, atual tanto do CBHRV quanto da AGBPV, e a partir das 23 entrevistas realizadas e das participações em campo do primeiro autor deste trabalho, o direcionamento atual é de se enfatizarem projetos de saneamento básico, planos diretores, projetos hidroambientais etc. Essa forma seria uma possibilidade de se capacitar os 51 municípios da bacia a melhorarem suas propostas e tentarem conseguir captar os outros recursos existentes citados. Certamente que esse não é um processo nem linear e nem garantido, uma vez que existem vários processos de negociação e qualificação local, informacional e organizacional envolvidos.

Aparentemente, há a possibilidade também do incremento da participação de novos usuários a este processo de captação de recursos, porém tal fato demandaria em si mesmo ao menos três medidas:

1) Maior conhecimento dos procedimentos de captação e investimentos econômicofinanceiros por parte dos possíveis novos participantes do sistema; o que poderia ser feito com uma larga aproximação entre o CBHRV e AGBPV e do sistema de gestão como um todo, pois tal se trata aqui de um problema de qualificação local;

2) Consolidação de um sistema de gerenciamento de informações de usuários, cada vez mais detalhado e orientado para a identificação dos usuários passíveis de cobrança por uso de recursos hídricos, pois se trata aqui de um problema também de qualificação local, mas também informacional;

3) Desenvolvimento de procedimentos de parcerias institucionais, projetos nacionais/internacionais ou afins para captação de recursos de investimentos conjuntos e/ou 
acoplados à cobrança por uso de recursos hídricos, pois se trata aqui de um problema de qualificação organizacional.

Essas ações estariam dentro de um contexto de busca por um planejamento além do clássico, mais voltado para processos de negociação do que a processos de execução de metas. Tal condição é indicada até pelo próprio Ministério de Meio Ambiente, que a sugere em termos de suas prioridades para aplicar o Plano Nacional de Recursos Hídricos (PNRH), previsto na Lei Federal $n^{\circ}$ 9.433/97para o período entre 2012-2015 (MMA, 2011). Porém, o próprio órgão reconhece que existem dificuldades para que isso se realize sem possíveis conflitos, dada a complexidade do tema. E para tal acontecer é importante também que os dados apresentados à população para o efetivo exercício do controle sejam mais bem trabalhados em termos de suas redações, descrições e facilidades de acesso, uma vez que estão pulverizados em várias fontes de dados e informações.

\subsection{CONCLUSÕES}

Com o cruzamento das pesquisas realizadas em termos documentais, de campo e nas entrevistas realizadas, o trabalho identificou que os recursos econômico-financeiros relacionados ao CBHRV são cada vez mais direcionados a partir das categorias existentes no PPA e seus três grandes grupos de atuação. Por outro lado, de acordo com as pesquisas de campo, entrevistas e análise documental, os recursos seriam muito inferiores à capacidade de investimentos na dimensão do necessário.

As documentações analisadas revelaram que todas diretrizes e estrutura institucional existentes carecem ainda de um desenvolvimento em termos interacionais e de capacidade de aplicação dos recursos. Há um descompasso temporal e funcional entre o comitê, o órgão gestor e o órgão executor da política de recursos hídricos na bacia, mas ao mesmo tempo esse processo tem sido construído e reconstruído nos últimos anos, com maior profissionalização das decisões.

De forma geral, há um reconhecimento de que o trabalho realizado pela AGBPV no desenvolvimento de uma transparência institucional em relação à gestão hídrica tem sido realizado, porém ainda é considerado distante do que as lideranças indicam como necessária. Pois não basta apenas a apresentação de relatórios, balancetes e afins para o desenvolvimento da governança enquanto capacidade de resposta, apesar de isso ser um começo. Ao contrário, 
os embates identificados entre a capacidade de pagamento da agência, seus repasses programados e as demandas do comitê requerem um trabalho de longo prazo e de aproximação constante entre os organismos de bacia relacionados. É um processo multiinstitucional para o gerenciamento da bacia, pois envolvem um rol de organizações responsáveis por organizar os investimentos econômicos, sob supervisão da AGBPV.

Como tem sido pesquisado pelos autores sobre as dimensões institucional/integradora/legal do comitê, há assimetrias institucionais e sociais nas relações que envolvem os aspectos de gestão na bacia hidrográfica do Rio das Velhas, que se traduzem nos investimentos econômico-financeiros em projetos de infraestrutura, de obras públicas e não de políticas públicas continuadas. E tal se vê muito mais priorizado do que ações de maior mobilização e interação social e institucional que podem, no longo prazo, fortalecer o modelo de gerenciamento proposto pelo comitê como mais participativo, democrático e compartilhado. Ou seja, o sistema de gestão deve ser construído menos em suas análises e decisões tecnicistas, com forte presença do aparato burocrático, e mais inclusivo dos diversos segmentos participantes do mesmo, com destaque para a sociedade civil organizada ou em vias de organização.

Se tal direcionamento irá ocorrer futuramente é difícil de se afirmar, uma vez que os montantes de investimentos necessários para a recuperação da bacia são muito maiores do que sua capacidade atual de captar recursos para tanto. É uma questão que vale a pena ser acompanhada, visto que a forma como investimentos econômico-financeiros são feitos revelam as prioridades de atuação institucional a cada momento. 


\section{CONSIDERAÇÕES FINAIS}

Apesar de no início dessa pesquisa a perspectiva de análise fosse pela análise da governança dos recursos hídricos, a mudança para a análise da gestão das políticas públicas de recursos hídricos se mostrou mais adequada. Não só pelo uso excessivo que o termo "governança" tomou nos últimos anos dentro das discussões sobre políticas públicas (policy) como também pelo fato de que a busca se deu pelos momentos que essas políticas passaram.

Nessa direção, a utilização de um estudo de caso em particular foi sendo observada como a metodologia, mas capaz de identificar como um conjunto de políticas públicas hídricas foram estabelecidas em território mineiro.Inicialmente, no entanto, o estudo de caso do Rio das Velhas havia sido pensado somente em si mesmo e com relação às suas possíveis dimensões legal, institucional, de integração e também econômica-financeira. Porém a inclusão do nível local, por exemplo, foi feita dada a importância da RMBH e do Colar Metropolitano; o nível regional por conta das UPGRHs existentes e de possíveis conflitos mineiros; o nível nacional por possibilitar uma comparação entre os arranjos e escolhas institucionais de cada estado; e o nível internacional por servir como ponderação sobre as formas de atuação de cenários políticos diferentes do brasileiro. As análises comparativas realizadas possibilitaram verificar uma posição real de destaque em nível regional e nacional do CBHRV e de algumas das razões porque ele é considerado como uma referência na temática da gestão de políticas públicas hídricas.

Primeiro, porque o comitê estudado soube fazer política de bastidores, sendo política aqui considerada como o exercício contínuo e/ou contingencial de poder a partir das demandas e objetivos colocados na agenda pública. Ao invés de separar (ou negligenciar) a atuação institucional da política, como vários organismos de bacia já fizeram ou ainda fazem, questionando os poderes estadual e municipais sempre que possível, o CBHRV demonstrou capacidade de agir nas oportunidades que apareceram para tal. Isso não quer dizer que momentos conflituosos não ocorreram. Ao contrário, como relatado, houve vários conflitos institucionais relatados, porém cada vez mais eles foram resolvidos via instâncias de negociação participativa do que de enfretamento público.

Programa de Pós-graduação em Saneamento, Meio Ambiente e Recursos Hídricos da UFMG 
Essa verificação indica, todavia, que nem todas as arestas de posicionamentos contrário já foram resolvidos no CBHRV, uma vez que o próprio processo da gestão participativa e integrada está em andamento. Mais ainda, a existência de conflitos é uma condição inerente a instâncias de decisão que são baseadas justamente na busca consensual de decisões coletivas tais como são encontradas em organismos de bacia, especialmente comitês.

Dentre as oportunidades que foram aproveitadas pelo CBHRV e que foram verificadas nas entrevistas, pesquisa de campo e documentos, as principais delas são aquelas vinculadas com ações estatais. E aqui vale uma consideração: o comitê pesquisado usou seu capital social advindo das suas organizações civis participantes, principalmente o Projeto Manuelzão, para tentar influenciar ações de políticas públicas de Estado e não de Governo. O que significa que a busca foi pela inclusão do comitê na agenda pública de maneira oficial, e não somente como um organismo componente do sistema de gestão estadual de recursos hídricos.

E tão somente este detalhe destoa da maioria das ações dos CBHs brasileiros estudados; pois estes praticam suas ações de gestão apenas ao nível das arenas convencionais de discussão dentro dos limites administrativos estritos. O que a pesquisa identificou foi que há alternativas de ações para além do que é estabelecido nas legislações vigentes em termos de parcerias, capacidade de influenciar processos, modificações nos desenhos institucionais em ação, etc.

Como exemplo temos a influência que o comitê do Rio das Velhas teve em pautar fortemente a agenda ambiental hídrica mineira no início dos anos 2000s como forma de tentar consolidar minimamente um sistema participativo de gestão pública hídrica. Pois caso não houvesse assim procedido, a tendência da repetição de um "comitê de gabinete" existir era muito grande, tal como ainda é possível de ser verificado em várias partes do país.

Pela análise do contexto da gestão institucional realizada, normalmente os CBHs não utilizam (ou não querem e/ou não sabem utilizar) todo o poder que possuem. Paradoxalmente, esse poder de atuação dos comitês é relativamente pequeno pois está legal e administrativamente circunscrito ao que determina as legislações nacionais (de recursos hídricos; de geração de energia; de saneamento; de recursos florestais; de meio ambiente, etc). Desde a forma da Lei das Águas de 1934 até a reforma feita pela PNRH em 1997, os comitês brasileiros são muito consultivos, deliberam com frequências irregulares entre si (a depender de seus quadros e desenho institucional), mas atuam relativamente pouco nos bastidores do palco das decisões 
político-administrativas. Consequentemente, seus limites de atuação também são esparsos e descontínuos.

Regiões onde inclusive há um envolvimento maior das partes interessadas têm demonstrado que a participação dos mesmos na construção e implantação de políticas públicas é fundamental à direção de resultados consistentes. Porém apenas gradativamente tem sido identificado o reconhecimento de que a participação social contínua e em todos os níveis é uma premissa incorporada às instituições.

No caso do CBHRV, ao possuir entre seus membros diversos representantes dos municípios da $\mathrm{RMBH}$, do $\mathrm{CMBH}$, tanto em termos de organizações sociais, usuários e governo, ajuda a construir um ambiente maior de cooperação, mesmo com os problemas inerentes ao modelo de gestão participativa. $\mathrm{O}$ comitê demonstrou de maneira geral que possui uma competência de articulação de interesses, não necessariamente melhor, dos CBHs estudados.

Isso aconteceu com intensidade na abertura de canais de participação crescentemente qualificada do próprio comitê. Por exemplo, foi identificada a prática da mobilização social desde seu início (agora oficializada, inclusive, na forma da Equipe de Mobilização Social), para dentro e para fora da estrutura dos organismos de bacia. Esse fato é um destaque na medida em que os setores ambientais não detinham essa movimentação junto ao campo midiático e políticos, como foi exercida pelo Projeto Manuelzão e depois pelo comitê em si (porém ainda fortemente influenciada pelo primeiro). Tal trabalho, em uma revisão de longo prazo, só foi possível por um trabalho constante junto aos membros do comitê e da população da bacia. As políticas públicas hoje estão mais para políticas de investimentos econômicos e financeiros do que para políticas públicas em si, no que se refere à inclusão social e técnica das populações e também da democratização das decisões.

A principal questão de pesquisa aqui colocada, sobre "quais são os principais fatores de restrição das ações do CBHRV a partir de uma perspectiva de governança?" e suas consequentes questões por temáticas, foram discutidas, como já salientado, em termos das suas dimensões institucionais, integradoras, legais e econômica-financeira. Para a interpretação do objeto de pesquisa a partir desse recorte, a escolha metodológica da triangulação de métodos para dar suporte às discussões foi empregada e identificou diversos aspectos da gestão dos recursos hídricos no território definido.

Programa de Pós-graduação em Saneamento, Meio Ambiente e Recursos Hídricos da UFMG 
Salienta-se mais uma vez que a proposta foi de se contextualizar os resultados alcançados em cada etapa do processo de pesquisa, assim como suas lacunas, limites e possibilidades encontradas tanto no sentido conceitual, legal ou metodológico e quais as principais contribuições possíveis de serem detalhadas para o avanço posterior da temática frente ao campo científico, acadêmico e profissional.

Nesse sentido, as análises institucionais indicaram que processos mais participativos e com maior controle social precisam ser consolidados tanto para a gestão como um todo em território mineiro, como para ao CBHRV em particular. A existência de diferentes atores envolvidos, se por um lado é uma premissa do sistema de gestão participativa de recursos hídricos, por outra demanda um sistema institucional integrado e onde todos os participantes têm condições semelhantes de informação e capacidade de influência nos processos de tomada de decisão.

Esse cenário ainda não acontece devido tanto aos interesses da agenda política de cada região e da bacia hidrográfica como um todo (que pode ou não favorecer maior participação das organizações), como também pela forte presença governamental nas práticas pesquisadas no comitê referido. Procedimentos de mobilização e participação social foram normalmente identificados como secundários frente aos processos por maiores investimentos em infraestrutura dos municípios e regiões.

Se no caso brasileiro, por exemplo, o direcionamento para maior gerenciamento ao nível local, municipal, não necessariamente se traduziu em avanços nos desenhos e práticas institucionais, no caso do CBHRV se identificou que práticas diferenciadas foram incorporadas inclusive na agenda pública governamental. Porém a submissão da gestão pública a um controle social constante é uma premissa ainda em consolidação.

Institucionalmente há uma fragmentação das ações de gestão, com os órgãos responsáveis pela gestão dos recursos hídricos a atuar de forma pouco articulada entre si e sem uma visão sistêmica. Tais afirmações são derivadas das análises metodológicas empregadas (pesquisa de campo; entrevistas; documentos) e, especificamente sobre os três aspectos de governança institucional avaliados - participação, transparência, práticas diferenciadas.

Estes aspectos reforçaram a identificação de que existem lacunas operacionais para a atuação do comitê como, por exemplo: participação social nos processos continua a merecer maior 
incremento, mais em qualidade do que em quantidade dos atores, que devem compreender melhor os processos de tomada de decisões; a sistemática da gestão demanda maior aprimoramento técnico-administrativo tanto dos membros do comitê como dos órgãos gestores; mesmo com forte direcionamento aos municípios como prática diferenciada, os mesmos não se encontram em condições de recursos humanos e materiais para exercer todo seu potencial na gestão dos recursos hídricos.

Por outro lado, a pesquisa verificou que: gradativamente o poder local (sociedade civil e municípios) vai se apropriando da dinâmica de gestão via comitê, que demanda maior participação e controle social; os conflitos têm se tornado mais transparentes e as discussões inter setoriais têm se desenvolvido no sentido de agregar decisões mais consensuais; as câmaras técnicas têm se aprimorado mais no sentido de dar suporte para as decisões colegiadas do modelo de comitê existente no Rio das Velhas; o modelo quadripartite tem criado mais condições para consultas e deliberações, principalmente com o reconhecimento das diferenças institucionais entre o poder público municipal e o estadual.

Já como diferenciais de inovação institucional e legal o trabalho verificou que as deliberações normativas se orientaram para o fortalecimento da gestão descentralizada via subcomitês, que são considerados como um avanço neste aspecto da gestão hídrica. Igualmente, o direcionamento dos recursos pelo uso de recursos hídricos para o estabelecimento de projetos e afins junto aos municípios foi muito considerado nas entrevistas e pesquisa de campo realizadas.

Porém, fato citado é que o sistema como um todo ainda é precário para a demanda existente, mesmo como arcabouço jurídico estabelecido. Esse distanciamento entre a teoria jurídica e a prática administrativa foi também citado de forma recorrente. Ao mesmo tempo, salienta-se mais uma vez que a presença governamental se mostrou constante e decisiva na forma como se deram os processos de mobilização social e de estruturação do CBHRV. Nessa direção, o modelo de comitê para recursos hídricos é menos um espaço para o exercício de práticas de governança e mais um local de realizações de discussões de teor burocrático e administrativo sob a vigilância governamental constante.

Já em termos das análises sobre a integração endógena/exógena no comitê escolhido, se verificou que, no aspecto endógeno, os níveis de informação, formação técnica e capacidade de liderança para discussões e participação são muito distintos, o que impede que a 
capacidade de governança nos processos decisórios se estabeleça como se pretende o modelo de comitê. Até por que se identificou que a capacidade de interpretação dos processos (documentais, interacionais e de conteúdo) está relacionada ao segmento de atuação dos membros, de forma geral, o que revela outra assimetria para a gestão participativa dos recursos hídricos.

Outra restrição verificada também foi sos subcomitês que formam o CBHRV estão em situações estruturais muito diferentes, sendo que os da Região Metropolitana de Belo Horizonte $(\mathrm{RMBH})$ têm demonstrado maior participação e condições de atuação. E em seu aspecto de integração exógena, se comprovou que o comitê estudado ainda precisa melhorar suas relações setoriais, uma vez que o desenho institucional varia conforme o tipo de organismo de bacia e o tipo de serviço público a ser executado.

Da mesma forma, a gestão da bacia hidrográfica é considerada mais em sua perspectiva técnica do que política, mais disciplinar do que multidisciplinar. Mas, pelo viés das possibilidades, o desenho institucional atual do comitê favorece o aparecimento de espaços de interação e discussão de propostas entre os membros e a instalação de treinamentos sistemáticos a partir das deficiências do comitê podem melhor qualitativamente as discussões internas/externas e diminuir atritos para consolidação de procedimentos baseados na governança.

As análises legais por sua vez demonstraram a existência de descompassos entre as determinações legais e suas práticas no cotidiano da gestão de recursos hídricos, seja em termos dos tempos para efetivação de suas determinações, seja pela existência de instituições com desenhos e definições operacionais distintas para fazer a gestão se realizar. De fato, há um arcabouço jurídico muito complexo e já em aplicação há várias décadas, mais tais não foram apreendidos ou efetivos nas práticas cotidianas do comitê estudado, uma vez que a governança presente na gestão dos recursos hídricos deve ser considerada mais em seu aspecto político do que somente jurídico.

Entre as disparidades existentes entre o campo institucional e jurídico e os processos de gestão ao nível do CBHRV e da bacia hidrográfica como um todo, pode-se salientar o desconhecimento do sistema de gestão, seja em questões jurídicas ou administrativas, a falta de um planejamento integrado e de longo prazo que consiga refletir as demandas sociais da bacia, assim como a ainda pouca adesão tanto das populações da mesma e do fato de que as 
regras para participação em na proposta do sistema descentralizado não estão claras aos seus participantes.

A partir da metodologia aplicada, a dimensão legal se mostrou insuficiente como mecanismo de direcionamento da gestão ao modelo descentralizado e participativo. Isto, porém deve ser entendido dentro de uma proposta maior que foi muito citada pelas lideranças de que somente com a incorporação do arcabouço jurídico em um modelo de mais articulado e mais interinstitucional. Logo, é identifico a gestão descentralizada e integrada em sua ótica legal e em uma perspectiva de boa governança é mais latente do que potente. Ela não se manifesta em toda a sua possibilidade, mas se mostra capaz de se desenvolver na medida em que circunstâncias contextuais sejam favoráveis. O fato de que há um envolvimento na gestão local e um aporte de investimentos podem ser considerados exemplos disso, porém ainda há muito a ser consolidado.

E sobre as análises econômicas-financeiras ficou evidenciada, primeiramente, a grande distância em termos dos recursos necessários para a recuperação socioambiental da bacia hidrográfica do Rio das Velhas e os recursos disponíveis para tanto. Nesse sentido, o direcionamento atual tanto da CBHRV e, principalmente, da AGBPV, é de se enfatizar projetos de saneamento básico, planos diretores municipais, eventuais cursos de capacitação e afins. Tais ações se encontram caracterizadas nos Planos Plurianuais de Aplicação (PPA), que diferenciam e orientam como econômica e financeiramente serão alocados os recursos para períodos de três anos consecutivos.

As documentações analisadas revelaram que todas diretrizes e estrutura institucional existentes carecem ainda de um desenvolvimento em termos interacionais e de capacidade de aplicação dos recursos. Há um descompasso temporal e funcional entre o comitê, o órgão gestor e o órgão executor da política de recursos hídricos na bacia, mas ao mesmo tempo esse processo tem sido construído e reconstruído nos últimos anos, com maior profissionalização das decisões.

De forma geral, há um reconhecimento do trabalho realizado da AGBPV no desenvolvimento de uma transparência institucional em relação à gestão hídrica, porém ainda é considerado distante do que as lideranças indicam como necessária. Pois não basta apenas a apresentação de relatórios, balancetes e afins para o desenvolvimento da governança enquanto capacidade de resposta. Ao contrário, os embates identificados entre a capacidade de pagamento da 
agência, seus repasses programados e as demandas do comitê requerem um trabalho de longo prazo e de aproximação constante entre os organismos de bacia relacionados.

Até porquê, como tem sido pesquisado pelos autores sobre as dimensões institucional/integradora/legal do comitê, há um déficit democrático nas relações que envolvem os aspectos de gestão na bacia hidrográfica do Rio das Velhas, que se traduzem nos investimentos econômico-financeiros em projetos de infraestrutura, de obras públicas e não de políticas públicas continuadas. E tal se vê muito mais priorizado do que ações de maior mobilização e interação social e institucional que podem, no longo prazo, fortalecer o modelo de gerenciamento proposto pelo comitê como mais participativo, democrático e compartilhado. O sistema de gestão deve ser construído menos em suas análises e decisões tecnicistas, com forte presença do aparato burocrático, e mais inclusivo dos diversos segmentos participantes do mesmo, com destaque para a sociedade civil organizada ou em vias de organização.

Finalmente, a pesquisa realizada visou identificar restrições e potencialidades da gestão das políticas públicas de maneira a contribuir para o aprofundamento de um tema que se encontra em crescente relevância no cenário nacional. Futuros aprofundamentos de pesquisa estão em aberto, uma vez que a gestão é um si um processo contínuo.

Em termos de pesquisa é possível identificar que o arcabouço jurídico dá pouco poder real de decisão e influência ao modelo de gestão via comitê. Apesar de já passados mais de dez anos de tal afirmação, ainda hoje os organismos de bacia ocupam um local secundário dentro da agenda política pública em Minas Gerais e no Brasil em geral, com destaque para os comitês de bacia. Prova disso é que o poder público tem ignorado as decisões e planejamentos dos planos diretores das bacias hidrográficas, e também as decisões estatais não consideram os comitês em relação às suas obras de infraestrutura. Fatos como a transposição do Rio São Francisco (HENKES, 2014) ou a canalização de córregos para a ampliação de avenidas em Belo Horizonte e outras cidades do país (capitais, principalmente) reforçam este argumento. 


\section{REFERÊNCIAS}

ABERS, R. N. Projeto Marca D’Água - Relatórios Preliminares 2001 - A Bacia do Rio das Velhas, Minas Gerais, 2001. Paper: Núcleo de Pesquisa em Políticas Públicas (UnB). Janeiro, 2002.

Organizing for governance: building collaboration in brazilian river basins. World Development. Vol. 35. No 8. 2007.

Água e Política: atores, instituições e poder nos Organismos Colegiados de Bacia Hidrográfica no Brasil. São Paulo: Annablume, 2010.

ABERS, R. N.; JOHNSSON, R. M. F.; FRANK, B.; KECK, M. E.; LEMOS, M. C. Inclusão, deliberação e controle: três dimensões de democracia nos comitês e consórcios de bacias hidrográficas no Brasil. Ambiente \& Sociedade. Vol. XII. No 1. Jan-Jun. 2009.

ABERS, R. N.; KECK, M. E. Comitês de bacia no Brasil: uma abordagem política no estudo da participação social. Revista Brasileira de Estudos Urbanos e Regionais. Vol. 6. No 1. 2004.

. The political construction of decision-making power in river basin committees. $6^{\circ}$ encontro da ABCP. 2007.

. Practical Authority. Oxford. New York: Oxford, 2013.

ABERS, R. N.; JORGE, K. D. Descentralização da gestão da água: por que os comitês de bacia estão sendo criados? Ambiente \& Sociedade. Vol. VIII. No 2. Jul-Dez. 2005.

ASSOCIAÇÃO BRASILEIRA DE ENGENHARIA SANITÁRIA E AMBIENTAL (ABES). Programa para revitalização da bacia do Rio das Velhas. Disponível em: <http://www.abesmg.org.br/visualizacao-de-clippings/pt-br/ler/3046/programa-para-revitalizacao-da-bacia-dorio-das-velhas-e-finalista-do-premio-furnas-ouro-azul>. Acesso em: 13 Jul. 2014.

AGÊNCIA DE DESENVOLVIMENTO METROPOLITANO DE BELO HORIZONTE (ADMBH). Dúvidas frequentes. Disponível em: http://metropolitana.mg.gov.br/pagina/duvidas-frequentes. Acesso em: 30 mar. 2016.

AGENCIA NACIONAL DE ÁGUAS (ANA). Evolução da organização e implementação da gestão de bacias no Brasil. Brasília: ANA. 2002.

2006.

. Consolidação da $1^{\text {a }}$ etapa do Plano Estadual de Recursos Hídricos de Minas Gerais.

Geo Brasil: Recursos Hídricos: resumo executivo. Brasília/DF. 2007.

Atlas das Regiões Metropolitanas: abastecimento de água. Resumo Executivo. Brasília: ANA, 2009.

. O Comitê de Bacia Hidrográfica: o que é e o que faz? Brasília: SAG, 2011(a).

. O Comitê de Bacia Hidrográfica: prática e procedimento. Cadernos de capacitação em recursos hídricos, Vol. 2, Brasília: SAG, 2011(b). ANA, 2012.

. Conjuntura dos recursos hídricos no Brasil: informe 2012. Edição especial. Brasília:

Alternativas organizacionais para gestão de recursos hídricos. Brasília: ANA, 2013(a).

. Conjuntura dos recursos hídricos no Brasil: informe 2013. Brasília: ANA, 2013(b).

Programa de Pós-graduação em Saneamento, Meio Ambiente e Recursos Hídricos da UFMG 
. Conjuntura dos recursos hídricos no Brasil. Informe 2014. Brasília. 2015(a).

. Conjuntura dos recursos Hídricos no Brasil - Encarte especial sobre a crise hídrica. Informe 2014. Brasília. 2015(b).

ALAMI, S.; DESJEUX, D.; MOUSSAOUI, I. G. Os métodos qualitativos. Petrópolis, RJ: Vozes, 2010.

ALMEIDA, A. C. A cabeça do brasileiro. 2a Ed. Rio de Janeiro: Record, 2007.

ALMEIDA, L. F. R., BROCH, S. A. O., DIAS, C. A., SOBRINHO, T. A. Análise do gerenciamento dos recursos hídricos de Mato Grosso do Sul. Revista de Gestão de Água da América Latina. V. 10, No 1, jan-jun 2013.

ANSELL, C.; GASH, A. Collaborative governance in theory and practice. Journal of Public Administration Research and Theory. Volume 18. Issue 4. 2007.

ARNESTEIN, S. R. "A Ladder of Citizen Participation," JAIP, Vol. 35, No. 4, July 1969, pp. 216-224.

AROEIRA, R. M. Recuperação ambiental de bacias hidrográficas, Belo Horizonte, Brasil.In: MACHADO, A. T. G. M. et al. (Org.). Revitalização de rios no mundo: América, Europa e Ásia. Belo Horizonte: Projeto Manuelzão, p. 221-240, 2010.

ARRETCHE, M. T. da S. "Tendências no estudo sobre avaliação", 1996, apud RICO, Elizabeth Melo (org.). Avaliação de Políticas Públicas: uma questão em debate. São Paulo, Cortez. 1998.

ASSOCIAÇÃO BRASILEIRA DE ENGENHARIA SANITÁRIA E AMBIENTAL (ABES). Disponível em: <http://www.abes-mg.org.br/visualizacao-de-clippings/pt-br/ler/3046/>. Acesso em: 13 jul. 2014.

ASSOCIAÇÃO DE USUÁRIOS PRÓ-GESTÃO DAS ÁGUAS DA BACIA HIDROGRÁFICA DO RIO DAS VELHAS (ASSUVE). Ata de Constituição do Estatuto Social. Belo Horizonte. 2005.

ATLAS DO DESENVOLVIMENTO HUMANO NO BRASIL (ATLAS BRASIL). (2013). Disponível em: < http://www.atlasbrasil.org.br/2013/>. Acesso em: 15 jan. 2016.

AVRITZER, L. Instituições participativas e desenho institucional: algumas considerações sobre a variação da participação no Brasil democrático. Opinião Pública. Vol. 14. No 1. Jun, 2008.

AZAMBUJA, D. Teoria Geral do Estado. 44ª ed., São Paulo: Globo, 2005.

BANCO MUNDIAL. Governance and Development. Washington, 1992.

Série Água Brasil: Estratégias de gerenciamento de recursos hídricos no Brasil. $1^{\text {a }}$ edição. Brasília, 2003.

BARDHAN, P. Governance issues in delivery of public services. Journal of African Economies. Vol. 13. Suppl. 1. 2004.

BARDIN, L. Análise de conteúdo. Lisboa: Edições 70, 1994.

BARRETEAU, O.; BOTS, P. W. G.; DANIEL, K. A. A framework for clarifying "participation" in participatory research to prevent its rejection for the wrong reasons. Ecology and Society. Vol. 15. No 2. 2010.

BAUER, M. W., GASKELL, G. Pesquisa qualitativa com texto, imagem e som: um manual prático. Capítulos 1, 2, 3, 8. Editora Vozes, 2008.

Programa de Pós-graduação em Saneamento, Meio Ambiente e Recursos Hídricos da UFMG 
BECK, U. Critical theory of world risk society: a cosmopolitan vision. Constellations, Volume 16, $\mathrm{n}^{\mathrm{o}}$ 1, 2009.

BECK, U.; GIDDENS, A., LASH, S. Modernização Reflexiva: política, tradição e estética na ordem social moderna. São Paulo: Editora Unesp, 1997.

BECKER, H. S. Métodos de pesquisa em Ciências Sociais. Indrodução, Capítulos 1 e 2. $3^{\text {a }}$ ed. São Paulo: Hucitec, 1997.

BATISTA, M. B. B., NASCIMENTO, N. O. Aspectos institucionais e de financiamento dos sistemas de drenagem urbana. Revista Brasileira de Recursos Hídricos, V. 7, nº 1, mar 2002.

BENSON, D., GAIN, A. K., ROUILLARD, J. J. Water Governance in a comparative perspective: from IWRM to a 'Nexus' approach? Water Alternatives, V. 8, nº 1, jan 2015.

BISWAS, A. K. Integrated water resources management: Is it working. International Journal of Water Resources Development. 2008.

BOBBIO, N. Estado, Governo, Sociedade - Para uma teoria geral da política. $14^{\mathrm{a}}$ Ed. Editora Paz e Terra. 2007.

BONTEMPO, V. L.; OLIVIER, C.; MOREIRA, C. W. de S.; OLIVEIRA, G. Gestão de águas urbanas em Belo Horizonte: avanços e retrocessos. Revista de gestão de água da América Latina. Vol. 9, no. 1, jan/jun 2012.

BORBA, M. L.; THEODORO, H. D.; NASCIMENTO, A., PORTO, M. Atenção do PNRH à integração, à descentralização e à participação. VII Simpósio de Hidráulica e Recursos Hídricos dos Países de Língua Oficial Portuguesa. Novembro, 2007.

BOSCARDIN, Cláudia Regina. A gestão de bacias hidrográficas urbanas: a experiência de Curitiba. Dissertação (Mestrado). Pontifícia Universidade Católica do Paraná. Curitiba. 2008.

BOUDON, R. Efeitos perversos e ordem social. Zahar Editores. Rio de Janeiro. 1979.

BOURLON, N.; BERTHON, D. Desenvolvimento sustentável e gerenciamento das bacias hidrográficas na América Latina. Revista Técnica e Informativa da CPRM. Vol. 2. No 10. 1998.

BOSCARDINI, Cláudia Regina. A gestão de bacias urbanas: a experiência de Curitiba. Dissertação de Mestrado. Pontifícia Universidade Católica do Paraná. 2008.

BRANNSTROM, C.; CLARKE, J.; NEWPORT, M. Civil society participation in the decentralization of Brazil's water resources: assessing participation in three states. Singapore Journal of Tropical Geography. Vol. 25, Issue 3. 2004.

BRITTO, A. L.; BARRAQUÉ, B. Discutindo gestão sustentável da água em áreas metropolitanas no Brasil: reflexões a partir da metodologia européia Water 21. Cadernos Metrópole, sem. 1 p. 123-142, 2008.

BRITO, A. L. N. de P., LIMA, S. C. R. Borges de; HELlER, L., CORDEIRO, B. de S. Da fragmentação à articulação. A Política Nacional de Saneamento e seu legado histórico. Revista Brasileira de Estudos Urbanos e Regionais, V. 14, No 1, maio 2012.

BRUNNENGRAEBER, A. Interdisciplinarity in governance research. GARNET Working Paper: No 08/06. September, 2006.

CÂMARA, R. H. Análise de conteúdo: da teoria à prática em pesquisas sociais aplicadas às organizações. Gerais: Revista Interinstitucional de Psicologia, nº 6, Vol. 2, jul-dez, 2013.

Programa de Pós-graduação em Saneamento, Meio Ambiente e Recursos Hídricos da UFMG 
CAMARGOS, L. de M. M. (Coord.). Plano diretor de recursos hídricos da bacia hidrográfica do rio das Velhas: resumo executivo - dezembro 2004. Belo Horizonte: Instituto Mineiro de Gestão das Águas, Comitê da Bacia Hidrográfica do Rio das Velhas, 2005.

. Governança de recursos hídricos: um estudo das percepções dos stakeholders sobre a gestão das águas no Estado de Minas Gerais. Dissertação de Mestrado. Fumec. 2008.

CAMPOS, C.J.G. Método de análise de conteúdo: ferramenta para a análise de dados qualitativos no campo da saúde. Revista Brasileira de Enfermagem, v. 57, nº 5, 2004.

CAMPOS, V. N. O.; FRACALANZA, A. P. Governança das águas no Brasil: conflitos pela apropriação da água e a busca da integração como consenso. Rev. Ambiente e Sociedade, Vol. 13, No. 2, p. 365-383, jul./dez. 2010.

CAMPOS, M. V. C. V., RIBEIRO, M. M. R., VIEIRA, Z. M. C. L. A gestão de recursos hídricos subsidiada pelo uso de indicadores de sustentabilidade. Revista Brasileira de Recursos Hídricos. Vol. 19, No 2, abr/jun. 2014.

CARMODY, L.; Doré, D.; PEIYUAN, G.; NETTE, A.S.; AN, J. Water in China: issues for responsable investors. Responsible Rearch. 2010.

CARNEIRO, E. J.; ASSIS, M. F. C. Conflitos ambientais em Minas Gerais: exploração da água na micorregião de São Lourenço. Estudios Sociales. Vol. XXI, No 41, 2012.

CARVAlHO, M. C. A. A. (1998). Participação social no Brasil hoje. Pólis Paper, n. 2, 27 p. Disponível em: http://polis.org.br/publicacoes/participacao-social-no-brasil-hoje/>. Acesso em: 05 jan. 2015.

CASTRO, C. N. Gestão das águas: experiências internacional e brasileira. Instituto de Pesquisa Econômica Aplicada. 2012.

CASTRO, J. E. Agua y gobernabilidad: entre la ideologia neoliberal y la memoria histórica. Cuadernos del Cendes. Ano 22. No 59. Ma-Ag. 2005.

Water governance in the twentieth-first century. Ambiente \& Sociedade. Vol X. No 2. Jul-Dez. 2007.

El estudio interdisciplinario de los conflictos por el agua en el medio urbano: una contribución desde la sociología. Caderno CENDES, 2008.

CASTRO, J.E.; HELlER, L. (Eds.). Water and sanitation services. Public policy and management. Chapter 1-5. Londres: Earthscan, 2009. 363p.

CASTRO, J. E.; HELLER, L., MORAIS, M. P. (Eds.). O direito à água como política pública na América Latina: uma exploração teórica e empírica. Brasília: Ipea, 2015.

CHIAVENATO, I. Introdução à Teoria Geral da Administração. $7^{a}$ Edição. Editora Campus. 2004.

COMITÊ DA BACIA HIDROGRÁFICA DO RIO ARAGUARI (CBH ARAGUARI). A bacia. Disponível em: 〈http://www.cbharaguari.org.br/a-bacia/rio-araguari> . Acesso em: 15 jan. 2016.

COMITÊ DA BACIA HIDROGRÁFICA DO RIO DAS VELHAS (CBHRV). Apresentação. Disponível em: <http://cbhvelhas.org.br/apresentacao/>. Acesso em: 24 abr. 2016. 2011(a).

Programa de Pós-graduação em Saneamento, Meio Ambiente e Recursos Hídricos da UFMG 
Mapa do Rio das Velhas. Disponível em <http://cbhvelhas.org.br/a-baciahidrografica-do-rio-das-velhas/>. Acesso em: 24 out. 2014. 2011(b).

. Atas de reunião, $\mathrm{n}^{\mathrm{o}} 1 \mathrm{a} \mathrm{n}^{\mathrm{o}} 15.2012$.

. Plano Plurianual de Aplicação (PPA) 2013-2014. Dezembro, 2012(a).

. Carta Aberta do Comitê da Bacia Hidrográfica do Rio das Velhas. Disponível em: $\overline{<\mathrm{https}}$ ://mobilizacaonabaciadoriodasvelhas.wordpress.com/>. Acesso em: 19 mai. 2015. 2012 (b).

. Localização da bacia hidrográfica do Rio das Velhas em relação à bacia hidrográfica do Rio São Francisco, Minas e Belo Horizonte. Disponível em: <http://www.cbhvelhas.org.br/index.php/more-about-joomla/a-bacia>. Acesso em: 01 out. 2013. 2013(a).

$\overline{2013(b)}$.

. História. Disponível em: <http://cbhvelhas.org.br/historia/>. Acesso em: 20 fev.

Câmaras Técnicas. Disponível em: < http://cbhvelhas.org.br/camaras-tecnicas/>. Acesso em: 01 jul. 2014(a).

. Subcomitês. Disponível em: <http://cbhvelhas.org.br/subcomites/>. Acesso em: 15 mar. 2014(b).

- Plano diretor de recursos hídricos da bacia hidrográfica do Rio das Velhas. Resumo Executivo. Belo Horizonte. 2015(a).

. Crise hídrica. Disponível em: <http://cbhvelhas.org.br/noticias/revista-rio-das-velhasno1-crise-hidrica-no-rio-das-velhas/>. Acesso em: 16 nov. 2015. 2015(b).

\begin{tabular}{l} 
Escassez hídrica gera conflito. Disponível em: \\
\hline <http://cbhvelhas.org.br/noticias/escassez-hidrica-gera-conflito-pelo-uso-da-agua-na-regiao-
\end{tabular} da-sub-bacia-ribeiro-bonito/>. Acesso em: 19 ago. 2015. 2015(c).

. Normas mineiras. Disponível em: < http://cbhvelhas.org.br/normas-mineiras/>. Acesso em: 15 jan. 2015(d).

- Unidades Territoriais Estratégicas (UTEs) - 2012. Disponível em: < http://www.solutionsforwater.org/wp-content/uploads/2012/01/Fig-4-Territorial-division-ofRio-das-Velhas-Basin.pdf>. Acesso em: 23 abr 2016. 2016.

COMITÊ DA BACIA HIDROGRÁFICA DO RIO DOCE. A Bacia. Disponível em: <http://www.cbhdoce.org.br/a-bacia/>. Acesso em: 05 mai. 2016.

COMITÊ DA BACIA HIDROGRÁFICA DO RIO IBICUÍ (CBH IBICUÍ). A bacia do Rio Ibicuí. Disponível em: < http://www.comiteibicui.com.br/abaciadorioibicui.php>. Acesso em: 08 mai. 2016.

COMITÊ DA BACIA HIDROGRÁFICA DO RIO MANHUAÇU. A Bacia. Disponível em: <http://www.cbhmanhuacu.org.br/a-bacia>. Acesso em: 15 jan. 2016.

COMITÊ DA BACIA HIDROGRÁFICA DO RIO PARÁ (CBH PARÁ). Quem somos. Disponível em: <http://www.cbhpara.org.br/quemsomos.htm>. Acesso em: 17 abr. 2016.

COMITÊ DA BACIA HIDROGRÁFICA DO RIO PARACATU (CBH PARACATU). Municípios integrantes. Disponível em: < http://www.cbhparacatu.com.br/p/municipiosintegrantes.html>. Acesso em: 13 mai. 2016.

Programa de Pós-graduação em Saneamento, Meio Ambiente e Recursos Hídricos da UFMG 
COMITÊ DA BACIA HIDROGRÁFICA DO RIO PARANAÍBA (CBH PARANAÍBA). Principais características. Disponível em: <http://cbhparanaiba.org.br/a-bacia/principaiscaracteristicas>. Acesso em: 08 jan. 2016.

COMITÊ DA BACIA HIDROGRÁFICA DO RIO PARANOÁ (CBH PARANOÁ). O Comitê. Disponível em: < http://www.cbhparanoa.df.gov.br/>. Acesso em: 15 jan. 2016.

COMITÊ DA BACIA HIDROGRÁFICA DOS RIOS PIRACICABA, CAPIVARI E JUNDIAÍ (CBH PCJ). Institucional. Disponível em: <http://www.comitespcj.org.br/>. Acesso em: 20 mar. 2016.

COMITÊ DA BACIA HIDROGRÁFICA DO RIO SÃO FRANCISCO (CBHSF). Apresentação. Disponível em: <http://cbhsaofrancisco.org.br>. Acesso em: 23 abr. 2016.

COMITÊ DA BACIA HIDROGRÁFICA DO RIO SUAÇUÍ (CBH SUAÇUÍ). Apresentação. Disponível em: <http://www.cbhsuacui.org.br/apresentacao>. Acesso em: 18/02/2016.

COMITÊ PARA INTEGRAÇÃO DA BACIA HIDROGRÁFICA DO RIO PARAÍBA DO SUL (CEIVAP). Apresentação do CEIVAP. Disponível em: <http://www.ceivap.org.br/apresentacao.php>. Acesso em: 23 Abr. 2016.

CONFEDERAÇÃO NACIONAL DE MUNICÍPIOS (CNM). (2014) Disponível em: $<$ http://www.cnm.org.br/noticias/exibe/mais-de-96-dos-munic\%C3\%ADpios-devemencerrar-o-ano-com-pend\%C3\%AAncias-no-cauc-aponta-a-cnm>. Acesso em: 09 fev. 2015.

COLEBATCH, H. K. Governing the use of water: the institutional context. Desalination. Vol 186. 2006.

CORTÊS, S. M. V. "Técnicas de coleta e de análise qualitativa de dados" in Cadernos de Sociologia/Programa de Pós-Graduação em Sociologia - PPGS/UFRGS. Volume 9. Porto Alegre, 1998.

CORTES, S. V.; LIMA, L. L. A contribuição da Sociologia para a análise de políticas públicas. Lua Nova. No 87. 2012.

COSTA, Maria Angélica Maciel. Reflexões sobre a política participativa das águas: o caso do CBH Velhas (MG). Dissertação de Mestrado. Universidade Federal de Minas Gerais. 2008.

COSTA, Francisco Emerson Vale. Uma experiência amazônica de gestão dos recursos hídricos: a criação do Comitê de Bacia Hidrográfica do Rio Tarumã-Açu, Manaus - AM Brasil. Universidade Federal do Pará. 2011.

COMPANHIA DE SANEAMENTO DE MINAS GERAIS (COPASA). Recursos hídricos: um planeta azul. 2014.

A Empresa. Disponível em: < http://www.copasa.com.br/wps/portal/internet/acopasa/a-empresa>. Acesso em: 13 Jul. 2017.

CUNHA, E. S. M.; THEODORO, H. D. Desenho institucional, democracia e participação: conexões teóricas e possibilidades analíticas. Belo Horizonte: Editora D’Plácido. 2014.

DALlARI, D. A. Elementos da Teoria Geral do Estado. 25 Ed. São Paulo: Saraiva, 2005.

DEMO, P. Introdução à metodologia da ciência. Capítulos 1 a 3. $2^{\mathrm{a}}$ Ed. São Paulo:1985.

DENHEZ, F. Tout savoir sur l'eau - Guide visuel. Éditions Marcel Didier. Canada. 2013.

DENZIN, N. K.; LINCOLN, Y. S. O planejamento da pesquisa qualitativa: teorias e abordagens. Capítulos 1 e 2. Porto Alegre: Artmed, 2006.

Programa de Pós-graduação em Saneamento, Meio Ambiente e Recursos Hídricos da UFMG 
DESLAURIERS, J. P. Recherche qualitative - Guide pratique. Chapitre 5. Chenelière/McGraw-Hill. Montréal. 1991.

DÉSVEAUX, E.; FORNEL, M. de (Orgs.). Faire des sciences sociales - Généraliser. Introduction. Éditions de L’École des Hautes Études en Sciences Sociales. Paris. 2012.

DOUROJEANNI, A.; JOURAVLEV, A. Gestión del agua a nivel de cuencas: teoría y práctica. CEPAL - Comissão econômica para América Latina e Caribe. 2002.

DULAC, V. F.; CRUZ, R. C. Mapeamento das ações de gestão dos recursos hídricos no âmbito de um comitê de gerenciamento de bacia hidrográfica. Revista Brasileira de Recursos Hídricos, v. 20, n. 3. p. 583-593. 2015.

DULCI, O. S. Política e recuperação econômica em Minas Gerais. Editora UFMG. Belo Horizonte. 1999.

EMPINOTTI, V. L. E se eu não quiser participar? O caso da não participação nas eleições do comitê de bacia do Rio São Francisco. Ambiente e Sociedade. Vol. XIV. No 1. Jan-Jun. 2011.

ENVIRONMENT AND CLIMATE CHANGE CANADA (ECCA). Disponível em: <https://www.ec.gc.ca/eau-water/default.asp?lang=En\&n=E05A7F81-1>. Acesso em: 11 fev. 2016.

ESMAN, M. J.; UPHOFF, N. T. Local Organizations - intermediaries in rural development. Capítulo 1. Londres. Cornell University Press. 1989.

ESTADO DE MINAS GERAIS (MINAS GERAIS). Decreto ${ }^{\circ}$ 39.692. Institui o Comitê da Bacia Hidrográfica do Rio das Velhas. 29 Jun 1998.

FUNDAÇÃO ESTADUAL DO MEIO AMBIENTE (FEAM). A questão ambiental em Minas Gerais: discurso e política. Belo Horizonte: Fundação João Pinheiro, 1998.

FIGUEIREDO, M. F.; FIGUEIREDO, A. M. C. Avaliação política e avaliação de políticas: um quadro de referência teórica. Revista Análise e Conjuntura. Belo Horizonte, 1986.

FILHO, T. A.; THIOLLENT, M. J. M. Metodologia para projetos de extensão: apresentação e discussão. Universidade Federal de São Carlos (UFSCar) : Cubo Multimídia, 2008.

FLICK, U. Qualidade na pesquisa qualitativa. Porto Alegre: Artmed, 2009.

FRANCE - MINISTÈRE DE L'ÉCOLOGIE, DU DÉVELOPPEMENT DURABEL, DES TRANSPORTS ET DU LOGEMENT. The democracy of water in the basins. 2014. Disponível em : <http://ifwn.org/wp-content/uploads/2014/09/plaquette-gouvernance-anglaislight.pdf $>$. Acesso em : 25 jun. 2016.

FRÉROT, A. L'eau - Pour une culture de la responsabilité. Éditions Autrement. Paris. 2009.

FREY, K. Políticas públicas: um debate conceitual e reflexões referentes à prática da análise de políticas públicas no Brasil. Planejamento e Políticas Públicas. No 21. 2000.

- A dimensão politica-democrática nas teorias de desenvolvimento sustentável e suas implicações para a gestão local. Ambiente \& Sociedade. Ano IV. No 9. 2001.

Abordagens de governança em áreas metropolitanas da América Latina: avanços e entraves. Revista Brasileira de Gestão Urbana. Vol. 4. No 1. Jan-Jun. 2012.

FUNG, A.; WRIGHT, E. O. (Orgs). Deepening democracy: institutional innovations in empowered participatory governance. Verso Editions. USA. 2003.

GARSON, S. Regiões metropolitanas: por que não cooperam? Rio de Janeiro: Letra Capital: Observatório das Metrópolis. Belo Horizonte, 2009.

Programa de Pós-graduação em Saneamento, Meio Ambiente e Recursos Hídricos da UFMG 
GEO BRASIL. Recursos hídricos: componentes da série de relatórios sobre o estado e perspectivas do meio ambiente no Brasil. Brasília: MMA; ANA, 2007.

GIDDENS, A. As conseqüências da modernidade. São Paulo: Unesp, 1991.

. A política da mudança climática. Rio de Janeiro: Zahar, 2010.

GIL, A.C. Métodos e técnicas de pesquisa social. São Paulo: Atlas, 1995.

. Estudo de caso. São Paulo: Atlas, 2009.

GIL, D. L. L. Negociação e gestão de conflitos. Instituto Politécnico de Engenharia de Coimbra. Dezembro, 2008.

GIROLETTI, D. Administração no Brasil: potencialidades, problemas e perspectivas. Revista de Administração de Empresas. Vol. 45. Edição Especial Minas Gerais. 2005.

GLOBAL WATER PARTNERSHIP (GWP). The Dublin Principles for Water as Reflected in a Comparative Assessment of Institutional and Legal Arrangements for Integrated Water Resources Management. Technical Advisory Committee (TAC). Número 3. 1999.

GLOBAL WATER PARTNERSHIP (GWP). China's water resources management challenge: the "three red lines". Technical Focus Paper. 2015.

GOLAFSHANI, N. Understanding reliability and validity in qualitative research. The Qualitative Report. Vol. 8, N 4, 2003.

GOOCH, G. D. e HUITEMA, D. "Improving governance through deliberative democracy initiating informed public participation in water governance policy processes". Paper. Stockhom Water Symposium. 2004.

GONÇALVES, A. O conceito de governança. CONPEDI, Manaus, Anais, 2006. Disponível em: < http://cgca.com.br/userfiles/file/o\%2\%20Alcindo\%20Goncalves.PDF>. Acesso em: 31 jan. 2015.

GOULART, E. M. A. (Org.). Navegando o Rio das Velhas das Minas aos Gerais. Vol. I e II. Belo Horizonte: Instituto Guaicuy - SOS Rio das Velhas/Projeto Manuelzão/UFMG, 2005.

GOVERNO DE MINAS GERAIS. Diagnóstico de Minas Gerais. Disponível em: <http://www.diagnostico.mg.gov.br/>. Disponível em: 17 fev. 2016.

GRANJA, S. I. B.; WARNER, J. A hidropolítica e o federalismo: possibilidades de construção da subsidiariedade na gestão de águas no Brasil?. Revista de Administração Pública. Rio de Janeiro 40(6) :1097-1121, Nov. /Dez. 2006.

GREEN, C. Mapping the field: the landscapes of governance. Flood Hazard Research Center. Middlesex University. London, 2007.

HAGUETTE, T. M. F. Metodologias qualitativas na Sociologia. $7^{\text {a }}$ edição. Rio de Janeiro: Editora Vozes, 2000.

HALL, D. Water in Public Hands. Public Service International. Londres. 2001.

HARMONICOP. Public participation and the European water framework directive: role of informations and communication tools. Work Package 3 report of the Harmonicop, 2003.

HARPHAM, T.; BOATENG, K. A. Urban governance in relation to the operation of urban services in developing countries. Habitat International. Vol. 21. Issue 1. 1997.

HELLER, L. Explaining successes and failures of river basin committees in Brazil. Brazilian Political Science Review. Vol. 8, No 1, p. 131-137. 2014.

Programa de Pós-graduação em Saneamento, Meio Ambiente e Recursos Hídricos da UFMG 
HELlER, L.; CASTRO, J. E. Política pública de saneamento: apontamentos conceituais. Revista Engenharia Sanitária e Ambiental. Vol 12. No 3. jul-set 2007.

HELLER, L.; REZENDE, S. C. Disciplina de "Políticas Públicas de Saneamento". Programa de Pós-Graduação em Saneamento, Meio Ambiente, Recursos Hídricos. 2012.

HELLER, P. G. B. Modelos de prestação dos serviços de abastecimento de água e esgotamento sanitário: uma avaliação comparativa do desempenho no conjunto dos municípios brasileiros. Tese de Doutorado. Universidade Federal de Minas Gerais. 2012.

HENKES, S. L. A política, o direito e o desenvolvimento: um estudo sobre a transposição do Rio São Francisco. Revista Direito GV. Vol. 10. No 2. jul-dez. São Paulo. 2014.

HIGGINS, S. S. O estudo dos efeitos não intencionais da ação intencional na teoria sociológica. Revista Sociologias. Ano 13. No 28, set-dez 2011.

HIRSCHMAN, A. Saída, voz e lealdade. São Paulo: Perspectiva, 1973.

HOORNBEEDK, J. A. Policy-making institutions and water policy outputs in the European Union and the United States: a comparative analysis. Journal of European Public Policy. Vol. 11. No 3. 2004.

INTER-AMERICAN DEVELOPMENT BANK (IADB, 2016). Saving for development How Latin America and the Caribbean can save more and better. Washington, 2016.

INSTITUTO BRASILEIRO DE GEOGRAFIA E ESTATÍSTICA (IBGE). Dados populacionais. 2010.

Área territorial brasileira em 2014. (2015). Disponível em: <http://www.ibge.gov.br/home/geociencias/areaterritorial/principal.shtm> . Acesso em: 15 jan 2016.

. Estimativas populacionais dos municípios em 2015. (2016). Disponível em: $<\mathrm{http}$ //saladeimprensa.ibge.gov.br/noticias?view=noticia\&id=1\&busca=1\&idnoticia=2972>. Acesso em: 31 jan. 2016.

INSTITUTO DO MEIO AMBIENTE E RECURSOS HÍDRICOS (INEMA). (2015). Comitês de bacia. Disponível em: <http://www.inema.ba.gov.br/gestao-2/comites-debacias/comites/cbh-itapicuru/>. Acesso em: 08 jan. 2016.

INSTITUTO MINEIRO DE GESTÃO DAS ÁGUAS (IGAM). Conferência das águas: resultado das pré-conferências. Belo Horizonte. 2000.

2006.

. Plano Estadual de Recursos Hídricos de Minas Gerais - Relatório Final. Dezembro,

. Primeira etapa do Plano Estadual de Recursos Hídricos de Minas Gerais - Relatório Técnico. Projeto Proágua/Semi-Árido. Junho, 2007.

Apresentação dos resultados do monitoramento e do índice de balneabilidade do Rio das Velhas, 2007.

. $7^{\circ}$ Fórum das Águas. Belo Horizonte. 2008.

. Relatório de ações 2008. Belo Horizonte. 2009.

. Unidades de Planjeamento e Gestão de Recursos Hídricos em Minas Gerais, 2010. Disponível em: <www.igam.mg.gov.br/images/stories/mapoteca/upgrhs-minas-gerais>. Acesso em: 05 fev. 2013. 
. Identificação de municípios com condição crítica para a qualidade de água na bacia do Rio das Velhas - Relatório 2013. Belo Horizonte. 2013.

. Financiamento público da pesquisa em recursos hídricos no Brasil: o Fundo Setorial CT-Hidro. Rio de Janeiro, 2012.

Normativos legais sobre a cobrança pelo uso da água. Disponível em: <http://www.igam.mg.gov.br/gestao-das-aguas/cobranca-pelo-uso-de-recursos-hidricos/1456normativos-legais-sobre-a-cobranca-pelo-uso-da-agua>. Acesso em: 19 dez. 2014(a).

Relatório de execução - Indicador 2: Planejamento e Gestão. Disponível em:<http://www.agbpeixevivo.org.br/images/AAGB/relatorios/cg03igam/2012relatorio\%20d e\%20mapeamento\%20E\%20acompanhamento12.pdf>. Acesso em: 10 dez. 2014(b).

$$
\text { Relatório de Gestão 2013. Disponível em: }
$$

<http://www.agbpeixevivo.org.br/images/2014/cg02igam/relatorios/relatorio_de_gestao_cg02 igam_exercicio2013.pdf>. Acesso em: $11 \mathrm{dez} .2014$ (c). $\begin{array}{ccccc} & \text { Relatório anual de acompanhamento das ações executadas, com recursos da cobrança } \\ \text { pelo } & \text { uso de hídricos. }\end{array}$ <http://www.agbpeixevivo.org.br/images/2014/cg02igam/relatorios/apendice\%20II\%20\%20r elatorio\%20anual\%20acompanhamento\%20DAS\%20acoes.pdf>. Acesso em: 13 dez. 2014(d).

Cobrança pelo uso de recursos hídricos. Disponível em: <http://www.igam.mg.gov.br/gestao-das-aguas/cobranca-pelo-uso-de-recursos-hidricos>. Acesso em: 29 dez. 2014 (e).

$2^{\circ}$ Relatório de gestão e situação dos recursos hídricos em Minas Gerais. Belo Horizonte. 2014(f).

- Cobrança pelo uso de recursos hídricos: Rio das Velhas. Disponível em:

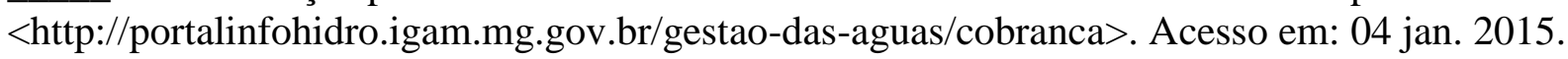

- Cobrança pelo uso de recursos hídricos: Rio das Velhas. Disponível em: <http://portalinfohidro.igam.mg.gov.br/gestao-das-aguas/cobranca>. Acesso em: 04 jan. 2015(a).

. $3^{\circ}$ Relatório de gestão e situação dos recursos hídricos em Minas Gerais. Belo Horizonte. 2015(b).

Cobrança pelo uso de recursos hídricos (2016(a)). Disponível em: <http://www.igam.mg.gov.br/gestao-das-aguas/cobranca-pelo-uso-de-recursos-hidricos〉. Acesso em: 18 Fev. 2016.

. Banco de notícias (2016(b)). Disponível em: < http://www.igam.mg.gov.br/banco-denoticias/1-ultimas-noticias/1644-pela-primeira-vez-cbhs-receberao-total-de-75-do-fhidropara-estruturacao>. Acesso em: 20 Abr. 2016.

- Planos de Recursos Hídricos (2016(c)). Disponível em: $\overline{<\mathrm{http}}$ //www.igam.mg.gov.br/gestao-das-aguas/plano-de-recursos-hidricos. Acesso em: 24 Abr. 2016.

INSTITUTO DE PESQUISA ECONÔMICA APLICADA (IPEA). Caracterização e quadros de análise comparativa da governança metropolitana no Brasil: Arranjos institucionais de gestão metropolitana. 2013.

Programa de Pós-graduação em Saneamento, Meio Ambiente e Recursos Hídricos da UFMG 
JOHNSSON, R. M. F.; LOPES, P. D. (Orgs). Projeto Marca D’água: seguindo as mudanças na gestão das bacias hidrográficas do Brasil: caderno 1: retratos 3 x 4 das bacias pesquisadas. 2003.

JOSHI, Y. K.; TORTAJADA, C.; BISWAS, A. K. Cleaning of the Singapore river and Kallang basin in Singapore: human and environmental dimensions. A Journal of the Human Environment. Vol 41, no 7, p. 647-658. 2012.

JORNAL MANUELZÃO. Edições 01 a 37. Belo Horizonte: Fumarc.

JÚNIOR, G. D. Direito Constitucional. 11ª Ed. Brasília: Vestcon, 2006.

JÚNIOR, Tarcísio Tadeu Nunes. As múltiplas territorialidades do planejamento e gestão das águas: olhares cruzados entre as regiões metropolitanas de Belo Horizonte e Paris. Tese (Doutorado). Universidade Federal de Minas Gerais. Belo Horizonte. 2013.

JÚNIOR, T. T. N.; HELLER, L; SILVA, P.L.; REZENDE, S; RADICCHI, A.L.A. Prestação dos serviços de água e esgotos em Sete Lagoas - MG: o SAAE é nosso ou que venha a COPASA. Revista Brasileira de Estudos Urbanos e Regionais. Vol. 12, No 1, p. 119-142. 2011.

KAUFMANN, D.; KRAAY, A. Governance and growth: causality which way? Evidence for the world, in brief. 2003.

KAUFMANN. D; KRAAY, A.; ZOIDO-LOBATÓN, P. Governance matters. The World Bank. 1999.

KOOIMAN, J. Interactive governance and governability: an introduction. Journal of Transdisciplinary Environmental Studies, vol. 7, nº 1, 2008.

JOSHI, Y. K.; TORTAJADA, C.; BISWAS, A. K. Cleaning of the Singapore river and Kallang basin in Singapore: human and environmental dimensions. A Journal of the Human Environment. Vol 41. No 7. 2012.

JURY, W. A.; JR, H. V. The role of science in solving the world's emerging water problems. Proceedings of the National Academy of Sciences of the United States of America. Vol. 102. No 44. 2005.

KETTELHUT, J. T. S.; AMORE, L.; LEEUWESTEIN, J. M. A experiência brasileira de implementação de comitês de bacias hidrográficas. Simpósio Internacional sobre Gestão de Recursos Hídricos. Gramado. 1998.

LISBOA, Apolo Heringer. Projeto Manuelzão: uma estratégia socioambiental de transformação da mentalidade social. Tese (Doutorado). Universidade Federal de Minas Gerais. Belo Horizonte. 2012.

LISBOA, A. H.; GOULART, E. M. A.; DINIZ, L. F. M. Projeto Manuelzão: a história da mobilização que começou em torno de um rio. Belo Horizonte: Instituto Guaicuy. 2008.

LOWI, T. J. American Business, Public Policy, Case-Studies, and Political Theory. World Politics. Vol. 16. No 4. 1964.

LUCHINI, A. de M. Os desafios à implementação do sistema de gestão dos recursos hídricos estabelecido pela Lei nº 9.433/97. Revista de Administração Pública. Vol. 34. No 1. 2000.

MACHADO, P. A. L. Direito Ambiental Brasileiro. 11 a ed. São Paulo: Malheiros Editores Ltda, 2003(a). 
MACHADO, Carlos José Saldanha. A gestão francesa de recursos hídricos: descrição e análise dos princípios jurídicos. Revista Brasileira de Recursos Hídricos. Vol. 8. No 4. OutDez. 2003(b).

MACKE, J.; SARATE, J. A. R. Desenvolvimento territorial e capital social: elementos, conexões e proposta de avaliação de territórios. Revista Brasileira de Gestão e Desenvolvimento Regional. Vol. 11. No 3. Set-Dez.2015.

MALUF, S. Teoria Geral do Estado. 31 a Ed. Editora Saraiva. 2013.

MANIKUTTY, S. Community participation: so what? Evidence from a comparative study of two rural water supply and sanitation projects in India. Development Policy Review. Vol. 15. 1997.

MANZINI, E. J. Uso da entrevista em dissertações e teses produzidas em um programa de pós-graduação em educação. Revista Percurso, v. 4, no 2, p. 149-171, 2012.

MARCH, J. G.; OLSEN, J. P. Neo-institucionalismo: fatores organizacionais na vida política. Revista de Sociologia Política. Vol 16, No 31, p. 121-142, novembro, 2008.

MARTINE, G. (Org.). População, Meio Ambiente e Desenvolvimento: verdades e contradições. $2^{\text {a }}$ edição. São Paulo. Editora da Unicamp. 1996.

MAYNTZ, R. Nuevos desafíos de la teoría de Governance. Instituto Internacional de Governabilitat de Catalunya. Barcelona, 2000.

MCDONNEL, R. A. Challenges for Integrated Water Resources Management: how do we provide the knowledge to support truly integrated thinking. International Journal of Water Resources Development. Vol. 24. No 1. 2008.

MELlO, M. C. C.; REZENDE, S. C. O Conselho Municipal de Saneamento de Belo Horizonte: desafios e possibilidades. Revista de Engenharia Sanitária e Ambiental. Rio de Janeiro/RJ: ABES, Vol. 19, nº 4, out-dez, 2014.

MENEGAT, R. Participatory democracy and sustainable development: integrated urban environmental management in Porto Alegre, Brazil. Environment \& Urbanization. Vol 14. No 2. 2002.

MINAYO, M. C. S. (Org.). Pesquisa social: teoria, método e criatividade. Petrópolis, RJ: Vozes, 2012.

Avaliação por triangulação de métodos: abordagem de programas sociais. Rio de Janeiro: Editora Fiocruz, 2005.

MELLO, C. A. B. Curso de Direito Administrativo. Parte I e II. 20ª ed. São Paulo: Malheiros Editores. 2006.

MELLO, M. C. C.; REZENDE, S. O Conselho Municipal de Saneamento de Belo Horizonte: desafios e possibilidades. Revista de Engenharia Sanitária e Ambiental. Rio de Janeiro/RJ: ABES, Vol. 19, n 4, out-dez, 2014.

MIGUEL, L. F. Dossiê "Mídia e Política”. Revista Sociologia Política. Curitiba. 2004.

. Consenso e conflito na teoria democrática: para além do "agonismo". Revista Lua Noval. No 92, 2014.

MINISTÉRIO DO MEIO AMBIENTE (MMA). Plano Nacional de Recursos Hídricos: Prioridades 2012-2015. Brasília, 2011.

Programa de Pós-graduação em Saneamento, Meio Ambiente e Recursos Hídricos da UFMG 
MOLLE, F. Development trajectories of river basins: a conceptual framework. Sri Lanka. 2003.

Tecnhnical and institutional responses to basin closure in the Chao Phraya river basin, Thailand. Water International, volum 29, number 1, pages 70-80. 2004.

MOREIRA, Carla Wstane de Souza. Gestão de águas urbanas: mobilização social em torno de rios invisíveis. Dissertação de mestrado. Universidade Federal de Minas Gerais. 2013.

MOREIRA, M. C.; SILVA, D. D.; LARA, M. S.; PRUSKI, F. F. Índices de conflito pelo uso da água da bacia do Ribeirão entre Ribeiros. Revista Brasileira de Recursos Hídricos. Volume 19, n. 1, jan/mar 2014.

MORIN, E. A cabeça bem feita - repensar a reforma, reformar o pensamento. $8^{a}$ Ed. Rio de Janeiro: Bertrand Brasil, 2003.

MOULAERT, F.; MARTINELLI, F.; SWYNGEDOUW, E.; GONZÁLEZ, S. Towards alternative model(s) of local innovation. Urban Studies. Vol. 42. No 11. 2005.

MOURA, M. Â. B.; ARAÚJO, R. C. P. Custo total da água como um bem social e econômico: o caso do sistema de abastecimento do conselho da praia, ilha de Santiago. Revista Brasileira de Recursos Hídricos. Volume 19, n. 4, out/dez 2014.

NEDER, R. T. Crise socioambiental: estado e sociedade civil no Brasil (1982-1998). São Paulo: Editora Annablume, 2002.

Bloqueios ao funcionamento de um fundo estadual de recursos hídricos no Brasil. 2001. Disponível em: <http://www.anppas.org.br/encontro_anual.pdf>. Acesso em: 01 maio 2015.

NELSON, C.; TREICHLER, P. A.; GROSSBERG, L. Cultural studies : an introduction. Cap. 1. Pp 1-16. New York. 1992.

NOGUEIRA, D. Organização social e teoria política aplicadas à gestão das águas brasileiras: a sociedade civil nas bacias do Rio das Velhas/Minas Gerais e do Rio dos Sinos/Rio Grande do Sul. VIII Congresso Luso-Afro-Brasileiro de Ciências Sociais. Portugal, 2004.

NORGAARD, R. B. Enviromental science as a social process. Environmental monitoring and assessment 20: 95-110, 1992.

NOORDEGRAAF, M.; NEWMAN, J. Managing in disorderly times. Public Management Review. Vol. 13. Issue 4. 2011.

OFFE, C. Capitalismo desorganizado. São Paulo: Brasiliense. 1997.

ORGANIZATION FOR ECONOMIC CO-OPERATION AND DEVELOPMENT (OECD). Governança dos Recursos Hídricos no Brasil. OECD Publishing, Paris. 2015.

2012.

. Water Governance in Latin America and the Caribbean. OECD Publishing, Paris.

ORGANIZAÇÃO DAS NAÇÕES UNIDAS (ONU). Países membros. Disponível em: <https://nacoesunidas.org/conheca/paises-membros/>. Acesso em: 17 mar. 2016.

OLIVEIRA, J. A. P. Desafios do planejamento em políticas públicas: diferentes visões e práticas. Revista de Administração Pública. Vol. 40. No 1. Mar-Abr. 2006.

OLSON, M. A lógica da ação coletiva: os benefícios públicos e uma teoria dos grupos sociais. São Paulo. Editora da Universidade de São Paulo. 1999.

Programa de Pós-graduação em Saneamento, Meio Ambiente e Recursos Hídricos da UFMG 
OSTRÖM, E. Governing the commons. Nova York. Cambridge University Press. 1990.

. Institutional Incentives and Sustainable Development - Infraestructure Policies in Perspective. Oxford: Westview Press. 1993.

POMPEU, C. T. Direito de águas no brasil. 2. ed. São Paulo: Editora Revista dos Tribunais, 2010.

PAQUEROT, S. Un monde sans gouvernail. Athéna Éditions. Canada. 2005.

PARÉS, M. River basin management planning with participation in Europe: from contested hydro-politics to governance-beyond-the-State. European Planning Studies. Vol. 19. No 3. 2011.

PEREIRA, T. S. T.; HELLER, L. Planos municipais de saneamento básico: avaliação de 18 casos brasileiros. Revista de Engenharia Sanitária e Ambiental. Vol. 20. No 3. Jul-Set. 2015.

PLANO METROPOLITANO DE BELO HORIZONTE (RMBH). Apresentação do Plano Metropolitano. Disponível em: < http://www.rmbh.org.br/>. Acesso em: 22 ago. 2016.

POLIGNANO, M. V. (Org.) Uma viagem ao Projeto Manuelzão e à bacia do Rio das Velhas: Manuelzão vai à escola. $3^{\text {a }}$ ed. Belo Horizonte: Projeto Manuelzão. 2004.

PORTAL DOS COMITÊS DE BACIA-MG (PCB-MG). Unidades de Planejamento (2016). Disponível em: <http://comites.igam.mg.gov.br/unidades-de-planejamento/1251>. Acesso em: 15 jan. 2016.

PORTAL INFO HIDRO (PIH). Gestão das águas e cobrança. Disponível em: <http://portalinfohidro.igam.mg.gov.br/gestao-das-aguas/cobranca>. Acesso em: 19 abr. 2016.

PORTO, M. F. A.; SILVA, R. T.; BRAGA, B.P.F. "Water management in Metropolitan São Paulo" in Water Resources Developmet. Vol. 22; No 2, 337-352. June, 2006.

PREFEITURA MUNICIPAL DE BELO HORIZONTE (PBH). Programa DRENURS/NASCENTES - Planejamento de ações. (2013). Disponível em: $<$ http://portalpbh.pbh.gov.br/pbh/ecp/comunidade.do?evento=portlet\&pIdPlc=ecpTaxonomia MenuPortal\&app=politicasurbanas\&lang=pt_br\&pg=5562\&tax=16906. Acesso em: 27 ago. 2015.

PRESTE, P.L. Ecopolítica internacional. Editora SENAC. São Paulo. 2000.

PROGRAMA DAS NAÇÕES UNIDAS PARA O DESENVOLVIMENTO (PNUD). Relatório do Desenvolvimento Humano 2015 - Relatório Síntese. 2015.

PROJECT MANAGEMENT INSTITUTE (PMI). A guide to the Project Management Body of Knowledge (PMBOK GUIDE). 5 ${ }^{\text {a }}$ Ed. PMI. 2015.

PROJETO MANUELZÃO. Curso de Gestão de Bacia Hidrográfica Rio das Velhas - Cd de apresentações. 2004.

. Bioindicadores de qualidade de água ao longo da bacia do Rio das Velhas (MG). Nuvelhas. 2010.

- Conheça o NuVelhas. Disponível em:

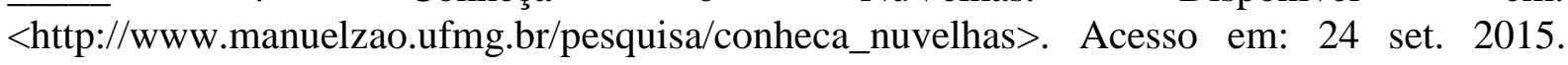
2011.

Programa de Pós-graduação em Saneamento, Meio Ambiente e Recursos Hídricos da UFMG 
Sobre o projeto - Meta 2014. Disponível em:

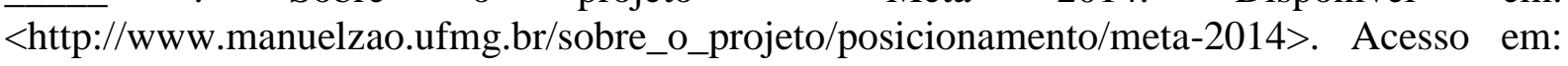
13 ago. 2015. 2012.

- Conflito pelo uso da água no Alto Rio das Velhas. Disponível em: <http://www.manuelzao.ufmg.br/comunicacao/noticias/conflito-pelo-uso-da-\%C3\%A1guano-alto-rio-das-velhas >. Acesso em: 19 ago. 2015. 2013(a).

- Se envolver para mudar. Disponível em: <http://www.manuelzao.ufmg.br/comunicacao/noticias/se-envolver-para-mudar>. Acesso em: 19 ago. 2015. 2013(b).

- Organização do Projeto Manuelzão. Disponível em: www.manuelzão.ufmg.br. Acesso em: 31 ago. 2015. 2013(c).

O que são os Núcleos Manuelzão. Disponível em: <http://www.manuelzao.ufmg.br/mobilizacao/nucleos/o-que-s\%C3\%A3o-n\%C3\%BAcleos.>. Acesso em: 30 mar. 2016. 2014.

Sobre o Projeto Manuelzão e sua bacia hidrográfica. Disponível em: < http://www.manuelzao.ufmg.br/sobre_o_projeto/a-bacia1>. Acesso em:

PUTNAM, R. D. How democracy works. Cambridge Press. 1998.

REMAUD, O.; SCHAUB, J. F.; THIREAU, I. Faire des sciences sociales - Comparer. Introduction. Éditions de L'École des Hautes Études en Sciences Sociales. Paris. 2012.

REPÚBLICA FEDERATIVA DO BRASIL (BRASIL). Constituição da República Federativa do. $76^{\mathrm{a}} \mathrm{Ed} .2012$.

. Lei Federal $n^{\circ}$ 9.433. Institui a Política Nacional de Recursos Hídricos, de 8 de janeiro de 1997.

. Lei Federal $n^{\circ}$ 9.984. Dispõe sobre a criação da Agência Nacional de Águas (ANA), de 17 de julho de 2000.

Apresentação do Senado Federal. Disponível em: <http://www12.senado.gov.br/ecidadania/visualizacaomateria?id=118684>. Acesso em: 07 fev. 2015.

REIGOTA, M. Meio ambiente e representação social. $3^{\text {a }}$ Ed. São Paulo: Cortez, 1998.

REZENDE, S. C.; HELLER, L. O saneamento no Brasil: políticas e interfaces. Belo Horizonte: Editora UFMG, 2008.

RIBEIRO, José Cláudio Junqueira. Desenvolvimento de modelo para avaliação de desempenho de política pública de meio ambiente. Estudo de caso: estado de Minas Gerais. Tese de doutorado. Universidade Federal de Minas Gerais. 2005.

. Indicadores ambientais : avaliando a política de meio ambiente no Estado de Minas Gerais. Belo Horizonte: FEAM, 2006.

RICHARD, S. ; RIEU, T. "Une approche historique de la gouvernance pour éclairer la gestion concertée de l'eau en France". 13th IWRA World Water Congress 2008. France, 2008.

ROGERS, P.; HALL, A. W. Effective water governance. The Background papers no. 7 GLOBAL WATER PARTNERSHIP - Technical Committee (TEC). Stockholm: Elanders Novum, 2003. 
RÖLING, N.; MAARLEVELD, M. Facing strategic narratives: an argument for interactive effectiveness. Agriculture and Human Values, n 16. 295-308. 1999.

ROTHSTEIN, B.; TEORELL, J. What is quality of government? A theory of impartial government institutions. Governance: An International Journal of Policy, Administration, and Institutions. Vol 21. No 2. 2008.

ROY, I. Good governance and the dilemma of development: what lies beneath? SocioEconomic Review. Vol. 3. 2005.

RUA, M. G.; ROMANINI, R. Para aprender políticas públicas. Instituto de Gestão de Economia e Políticas Públicas. Vol. 1. 2013.

SAETREN, H. Facts and Myths about Research on Public Policy Implementation: Out-ofFashion, Allegedly Dead, But Still Very Much Alive and Relevant. The Policy Studies Journal, Vol. 33, No. 4, 2005.

SANDERSON, I. Evaluation, policy learning and evidence-based policy making. Public Administration. Vol. 80. No 1. 2002.

SANTOS, J. A.; FILHO, D. P. Metodologia científica. $2^{\text {a }}$ Ed. São Paulo: Cengage Learning, 2011.

SECRETARIA DE ESTADO DE DESENVOLVIMENTO REGIONAL E POLÍTICA URBANA (SEDRU). Plano Diretor de Desenvolvimento Integrado da Região Metropolitana de Belo Horizonte. Minas Gerais. 2011.

SECRETARIA DE ESTADO DE MEIO AMBIENTE E DESENVOLVIMENTO SUSTENTÁVEL (SEMAD). Pela primeira vez, CBHs receberão total de 7,5\% do FHIDRO para estruturação (2016). Disponível em: < http://www.meioambiente.mg.gov.br/>. Acesso em: 18 Abr. 2016.

SEPÚlVEDA, R; LEMOS, R.; SPOSITO, P.; THEODORO, H. D. Planejamento e gestão participativos: a metodologia para início da aplicação dos recursos da cobrança pelo uso da água na bacia hidrográfica do Rio das Velhas. XIV Congresso Mundial da Água. 2011.

SILVA, D. D. S.; PRUSKI, F. F. (Orgs). Gestão de Recursos Hídricos: aspectos legais, econômicos, administrativos e sociais. Porto Alegre: Editora ABRH, 2000.

SILVA, S. R. O papel do sujeito em relação à água de consumo humano: um estudo na cidade de Vitória-ES. Tese de Doutorado. Universidade Federal de Minas Gerais. 2007.

SILVA, O. A. Planejamento territorial e gestão de recursos hídricos: a água enquanto ativo ecosocial. Revista Recursos Hídricos. Vol. 36. No 2. Nov. 2015.

SIMPSON, L.; RINGSKOG, K. Water markets in the Americas. Chapter 5. Washington: World Bank. 1997.

SIMPUNGWE, E. L. Water, stakeholders and common ground: challenges for MultiStakeholder Platforms in Water Management in South Africa. Wageningen University. 2006.

SISTEMA ESTADUAL DE MEIO AMBIENTE E RECURSOS HÍDRICOS (SISEMA). Seminário sobre outorga e alocação de água em bacias críticas - Introdução aos conceitos de área de conflito e processo único de outorga (outorga coletiva). Brasília. 2015.

SWYNGEDOUW, E. Governance innovation and the citizen: the Janus face of governancebeyond-the-State. Urban Studies. Vol. 42. No 11. 2005.

Programa de Pós-graduação em Saneamento, Meio Ambiente e Recursos Hídricos da UFMG 
. Into the sea: desalination as hydro-social fix in Spain. Annals of the Association of American Geographers. 2013.

SOARES, S. I. O. A mediação de conflitos na gestão de recursos hídricos no Brasil. Dissertação de Mestrado. Universidade de São Paulo. São Paulo, 2008.

SOUZA, C. Políticas Públicas: uma revisão de literatura. Revista Sociologias, Porto Alegre, ANO 8, No 16, Jul-Dez. 2006.

SOUZA, A.; SCHUNEMANN, C. Gerenciamento do escopo e da comunicação em projetos. AVM Instituto. 2010.

THEODORO, H. D. Instituições e gestão de recursos hídricos em Minas Gerais. Dissertação de Mestrado. Universidade Federal de Viçosa, 2002.

. Novas iniciativas na gestão dos recursos hídricos em Minas Gerais. II Encontro Nacional da Anppas, Indaiatuba. São Paulo. 2004.

. Multi-Stakeholders Platforms em uma contextualização conceitual. Revista de Administração Arnaldo, Volume 1, n. 02, Janeiro/Dezembro 2010.

A importância da implementação dos planejamentos. Jornal da Sociedade Brasileira

para o Progresso da Ciência (SBPC). Disponível em: <http://www.jornaldaciencia.org.br/Detalhe.jsp?id=79455>. Acesso em: 22 mar. 2016.

A política da mudança climática. Interseções: Revista de Estudos Interdisciplinares. Resenha, Ano 14, nº 1. Rio de Janeiro: UERJ. 2013.

. Proposta de gestão de projetos aplicada à avaliação de técnicas de tratamento de água para controle de cianobactérias na bacia hidrográfica do Rio das Velhas, Minas Gerais. Revista Agenda Social. Volume 8. Número 1. Rio de Janeiro. 2014.

THEODORO, H. D.; ANDRADE, I. C. M.; LANA, L. C. O. Plano Estadual de Coleta Seletiva de Minas Gerais: perspectivas e desafios. Revista Agenda Social, V. 6, nº 2, 2013.

THEODORO, H.D.; NASCIMENTO, N. O.; HELLER, L. Recursos econômico-financeiros para a construção da governança dos recursos hídricos: insuficiências, assimetrias e opacidades na bacia hidrográfica do Rio das Velhas, Minas Gerais, Brasil. Revista Recursos Hídricos. Vol. 37. No 2. Portugal. 2016.

THEODORO, H. D.; MARQUES, D. Análise de modelos institucionais de recursos hídricos, com foco em Minas Gerais, Brasil. Revista Sustentabilidade em Debate. V.5, n. 1, p. 117-135, jan/abr. Brasília: UnB, 2014.

THEODORO, H. D.; MATOS F. Governança e recursos hídricos: experiências nacionais e internacionais. Belo Horizonte: D’Plácido, 2015.

TORTAJADA, C. Institutions for integrated river basin management in Latin America. Water Resources Development, Vol. 17, nº 3, 289-301, 2001.

TORTAJADA, C; CASTELÁN, E. Water Management for a megacity: Mexico City Metropolitan Area. A Journal of the Human Environment. Vol 32. No 2. 2003.

TOTTI, M. E.; AZEVEDO, S. Gestão de recursos naturais de uso comum: peculiaridades e abordagens teóricas. Revista Brasileira de Recursos Hídricos, Vol. 18. No 3. 2013.

TRAWICK, P. B. Going with the flow: the state of contemporary studies of water management in Latin America. Latin American Research Review. Vol. 40. No 3. 2005.

Programa de Pós-graduação em Saneamento, Meio Ambiente e Recursos Hídricos da UFMG 
TREVISAN, A. P.; BELLEN, H. M. Avaliação de políticas públicas: uma revisão teórica de um campo em construção. Revista de Administração Pública. Vol. 42. No 3. Maio-Jun. 2008.

TRIBUNAL SUPERIOR ELEITORAL (TSE). Partidos políticos registrados no TSE (2015). Disponível em: <http://www.tse.jus.br/partidos/partidos-politicos/registrados-no-tse>. Acesso em: 23 jan 2016.

Eleições anteriores. Disponível em: <http://www.tse.jus.br/eleicoes/eleicoesanteriores/eleicoes-anteriores>. Acesso em: 22 jul. 2015.

TUCCI, C. E. M. Gestão da Água no Brasil - Brasília : UNESCO, 2001.

TURTON, A. R.; HATTINGH, J.; CLASSENS, M.; ROUX, D. J.; ASHTON, P. J. Towards a model for ecosystem governace: An integrated water resource management example. In: (Org.) TURTON, et al. governance as a trialogue: government - Society-Science in transition. Berlin: Springer, 2007.

UNITED NATIONS EDUCATIONAL, SCIENTIFIC AND CULTURAL ORGANIZATION (UNESCO). Water: a shared responsability. Report 2. 2006.

. Global Water Governance: conceptual design of global institutional arrangements. Março. 2008.

. Managing water under uncertainty and risk. France. 2012.

UNITED NATIONS UNIVERSITY (UNU). Integrating biodiversity with local and city planning: the experience of the studios in the development of local biodiversity strategies and action plans (LBSAPs). Institute for the Advances Study of Sustainability. Japan. 2014.

UNITED NATIONS DEVELOPMENT PROGRAMME (UNDP). Governing water wisely for sustainable development. 2003.

UNITED STATES GEOLOGICAL SURVEY (USGS). Disponível em: <http: //water.usgs.gov/programs.html>. Acesso em: 09 fev. 2016.

UNITED STATES DEPARTMENT OF STATE (STATE). Disponível em: http://www.state.gov/e/oes/water/. Acesso em: 12 jul. 2016.

VEIGA, L. B. E.; MAGRINI, A. The brazilian water resources management fifteen years of success and chanllenges. Vol. 27. Issue 7. 2013.

VELLOSO, Tatitana Ribeiro. A gestão dos recursos hídricos em um context regional: a trajetória do Departamento Nacional de Obras Contra as Secas (DNOCS). Dissertação de Mestrado. Viçosa: UFV. 2000.

VIOLA, E.; FERREIRA, L. C. Incertezas de sustentabilidade na globalização. Campinas: Unicamp, 1996.

WARNER, J. More sustainable participation? Multi-stakeholder Platforms for integrated catchment management. Water Resources Development. Volume 22. Número 1. Páginas 1535. 2007.

Multi-Stakeholder Platforms: integrating society in water resource management?. Revista Ambiente e Sociedade. Vol. VIII. Número 2. Jul/Dez. 2005.

WARNER, J. (Editor). Multi-Stakeholder Platforms for Integrated Water Managment. The Netherlands. Ashgate Publishing Limited. 2007.

WEBER, M. Economia e sociedade. Vol. 2. Brasília: UnB. 1999.

Programa de Pós-graduação em Saneamento, Meio Ambiente e Recursos Hídricos da UFMG 
WEBLER, T.; TULER, S.; KRUEGER, R. What is a good public participation process? Five perspectives from the public. Environmental Management. Vol. 27. No 3. 2001.

WESTER, S. M. Providing Irrigation Services in Water-Scarce Basins: Representation and Support. Ashgate Publishing Limited. 2005.

WOSTL, C. P.; KRANZ, N. Environmental Science \& Policy. Editoral. No 13. 2010.

YIN, R. K. Estudo de caso: planejamento e métodos. Capítulos 1, 3 e 4. $4^{\mathrm{a}}$ Ed. Porto Alegre: Bookman, 2010. 


\section{APÊNDICES}

\section{Lista de Entrevistados}

Comitê da Bacia Hidrográfica do Rio das Velhas (CBHRV)

1. CBHRV 4 - (3 ex-Presidentes e Presidente atual (2013-2017)).

2. AGBPV 3 - Diretores: Geral; Técnica; Integração.

Poder Público Estadual

3. EMATER 1 - Gerente de Meio Ambiente.

4. IGAM 2-Ex-Presidente e Diretor.

5. SEE 1 - Gerente.

Poder Público Municipal

6. $\mathrm{PBH}$ 1-Gerente de Planejamento e Monitoramento Ambiental.

7. $\mathrm{AMBH}$ 1-Gerente.

Usuários
8. FIEMG
1-Gerente de Meio Ambiente.
9. FIEMG
1-Consultora Sênior.
10.COPASA
1-Gerente.

Sociedade Civil

11.Projeto Manuelzão

2-Grupo de Educação e Mobilização.

12.ABES

2-Presidente; Gerente.

13.ADAO

1-Presidente.

14.CONVIVERDE 1-Presidente.

15.ACOMCHAMA 1-Presidente.

16.ANSP 1-Presidente.

IES
17.UFMG
1-Docente.
18.UnB
1-Docente. 


\section{Roteiro de Entrevista}

Entrevista $n^{0}$ :

Data:

Início:

Nome:

Idade:

Sexo:

Naturalidade:

Instituição:

Segmento:

\section{Questão de introdução/relaxamento}

"Fale-me um pouco do sr(a) e de suas experiências pessoais e profissionais relacionadas à bacia hidrográfica do Rio das Velhas"

\subsection{Meio Físico}

\subsubsection{Uso e Ocupação do solo}

13.1.1.1 "Como o(a) sr(a) analisa o uso e a ocupação do solo na bacia hidrográfica do Rio das Velhas?

13.1.1.2 "Como tem sido realizada a destinação dos resíduos sólidos e efluentes relacionados ao Rio das Velhas na sua opinião?"

\subsection{Meio Biótico}

13.2.1 Quantidade de água

13.2.1.1 "O(A) sr(a) identifica melhorias na quantidade da água existente no Rio das Velhas? Quais seriam, na sua opinião?"

13.2.1.2 "Onde o(a) sr(a) identifica melhorias na quantidade da água existente no Rio das Velhas? Quais seriam, na sua opinião?"

\subsubsection{Qualidade de água}

13.2.2.1 "O(a) sr(a) identifica melhorias na qualidade da água existente no Rio das Velhas? Quais seriam, na sua opinião, caso afirmativo?”

\subsubsection{Bioindicadores}

13.2.3.1 "O(a) Sr(a) percebe que há melhorias na fauna e flora relacionadas à bacia hidrográfica do Rio das Velhas? Quais seriam, em caso afirmativo?"

\subsection{Meio Antrópico}

\subsubsection{Dimensão Institucional}

13.3.1.1 "Como o(a) sr(a) analisa a gestão de recursos hídricos na bacia hidrográfica do Rio das Velhas de forma geral?"

13.3.1.2 "Como o(a) sr(a) analisa a gestão de recursos hídricos na bacia hidrográfica do Rio das Velhas pelo CBHRV?'

13.3.1.3 "O que o(a) sr(a) achou da mudança da gestão de macro áreas para as UTEs (Unidades Territoriais Estratégicas), melhorou, piorou ou não houve alteração?"

13.3.1.4 "Os municípios tem participado mais da gestão dos recursos hídricos e no CBHRV em particular? Se não, quais os motivos na sua opinião?" 
13.3.1.5 "O CBHRV tem realizado práticas diferenciadas de gestão na sua opinião? Caso afirmativo, quais seriam elas e como modificaram o gerenciamento dos recursos hídricos e humanos na bacia?"

\subsubsection{Dimensão Integradora}

13.3.2.1 "Na sua opinião existem muitos problemas, conflitos de interesses ou afins na relação entre os membros do CBHRV? Quais seriam os mais importantes" - Endógena.

13.3.2.2 "Na sua opinião, quais os principais conflitos de interesse e, ou de idéias entre as instituições responsáveis pelos recursos hídricos do Rio das Velhas?" - Exógena.

\subsubsection{Dimensão Legal}

13.3.3.1 "Quais os principais desafios para a implementação legal dos mecanismos de gestão na bacia hidrográfica do Rio das Velhas?”

13.3.3.2 "Quais poderiam ser os exemplos que o(a) sr(a) poderia dizer sobre as disparidades entre teoria e prática no CBHRV ou na AGBPV?"

\subsubsection{Dimensão Econômica-Financeira}

13.3.4.1 "O(A) $\quad$ sr(a) sabe/conhece quais os mecanismos para aplicação dos recursos hídricos na bacia hidrográfica do Rio das Velhas?"

13.3.4.2 "O que seria o "Plano de Aplicação" do Rio das Velhas na sua opinião e como ele pode ser melhor aplicado?"

\section{Questões de encerramento}

"O sr(a) deseja falar mais alguma outra questão que não foi abordada nesta entrevista?"

"O sr(a) poderia indicar mais alguma outra pessoa de referência para participar desta pesquisa e que conheça bem a bacia hidrográfica do Rio das Velhas?"

\section{Duração:}

